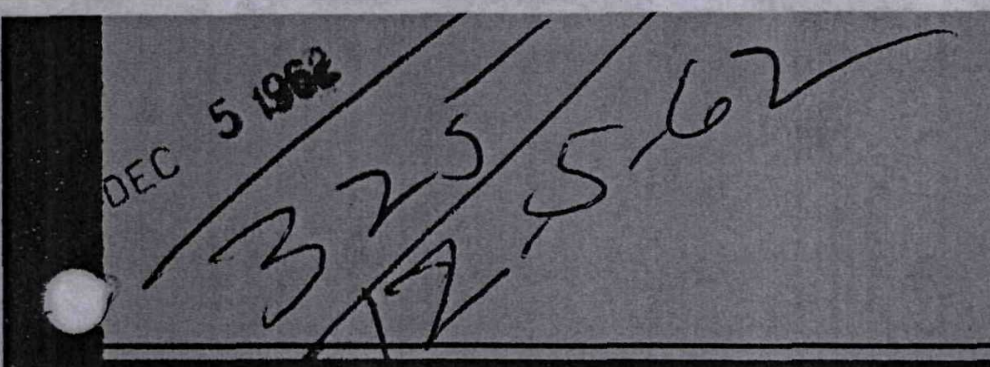

BMI-1 598

\title{
MSTE: \\ PROPERTIES OF FUELS \\ FOR \\ HIGH-TEMPERATURE REACTOR CONCEPTS
}

BATTELLE MEMORIAL INSTITUTE 


\section{DISCLAIMER}

This report was prepared as an account of work sponsored by an agency of the United States Government. Neither the United States Government nor any agency Thereof, nor any of their employees, makes any warranty, express or implied, or assumes any legal liability or responsibility for the accuracy, completeness, or usefulness of any information, apparatus, product, or process disclosed, or represents that its use would not infringe privately owned rights. Reference herein to any specific commercial product, process, or service by trade name, trademark, manufacturer, or otherwise does not necessarily constitute or imply its endorsement, recommendation, or favoring by the United States Government or any agency thereof. The views and opinions of authors expressed herein do not necessarily state or reflect those of the United States Government or any agency thereof. 


\section{DISCLAIMER}

Portions of this document may be illegible in electronic image products. Images are produced from the best available original document. 


\section{CORRIGENDA}

\section{BMI- 1598, PROPERTIES OF FUELS FOR HIGH-TEMPERAT URE REACTOR CONCEPTS}

$$
\text { July } 1,1963
$$

Please attach to report or make the following changes on the appropriate pages.

Page

6 Fuel Comparison Table: Substitute the following values for the thermal conductivities for $\mathrm{UO}_{2}$ in cal/ $(\mathrm{sec})(\mathrm{cm})(\mathrm{C}): 0.026$ at $20 \mathrm{C}, 0.008$ at $600 \mathrm{C}, 0.005$ at $1200 \mathrm{C}$.

11 Section C6: Rupture time for $1600 \mathrm{~F}$ should be 60.2 instead of 602 .

17 Section C6: Revise as follows:

\begin{tabular}{|c|c|c|c|c|c|}
\hline \multirow[b]{2}{*}{$\begin{array}{c}\text { Temperature, } \\
F\end{array}$} & \multicolumn{3}{|c|}{ Stress for Creep Rate Shown, psi } & \multicolumn{2}{|c|}{ Rupture Data } \\
\hline & $\begin{array}{c}0.001 \mathrm{Per} \\
\text { Cent per } \mathrm{Hr}\end{array}$ & $\begin{array}{c}0.01 \mathrm{Per} \\
\text { Cent per Hr }\end{array}$ & $\begin{array}{c}0.1 \text { Per } \\
\text { Cent per } \mathrm{Hr}\end{array}$ & $\begin{array}{c}\overline{\text { Stress }} \\
\text { psi }\end{array}$ & $\begin{array}{c}\text { Rupture Time, } \\
\mathrm{hr}\end{array}$ \\
\hline 1600 & 9,800 & 14,900 & 22,000 & 30,000 & 38.7 \\
\hline 1800 & 7,800 & 10,000 & 13,000 & $\begin{array}{l}20,000 \\
15,000\end{array}$ & $\begin{array}{r}27.2 \\
169.7\end{array}$ \\
\hline
\end{tabular}

53. Table G2: Add the superscript (b) to the 4.8 entry, last line in first column, and place the following footnote below the table:

(b) Reaction between UC and tantalum containe r resulted in the large density change shown, and also affected the fission-gas release.

65 Section B6a: Vaporization equation for above $2000 \mathrm{~K}$ should read :

$\log \mathrm{p}(\mathrm{mm} \mathrm{Hg})=13.298-\frac{3.7195 \times 10^{4}}{\mathrm{~T}}+\frac{3.5612 \times 10^{6}}{\mathrm{~T}^{2}}+\frac{2.6178 \times 10^{9}}{\mathrm{~T}^{3}}$

77 Figure D2b: Chalk River curve should be labeled "UO 2 "; thermal-conductivity unit on ordinate should read: $w /(\mathrm{cm})(C)$.

82 Section F2e should read: Stainless steel No reaction at $2400 \mathrm{~F}$. Tungsten fast reaction at $2065 \mathrm{C}$.

84 Section G2b(3) should have appended at the end of the sentence: "... at temperatures up to $3000 \mathrm{~F}$."

84 Section G2c: Next to last line on the page insert "observed" between the words differences and between and "(for in-pile release)" between the words models and is.

109 Section A3, second line correction: "characteristics" instead of "characreristics".

111 Table C5 correction: "BeO" instead of "Beo". 
117 Section G5a: Delete from next-to-last sentence: . . "and $\mathrm{UO}_{2}$ loses its crystallinity in the range of 36 to $64 \times 10^{20}$ fission fragments per $\mathrm{cm}^{3 \prime \prime}$.

118 Table Gl: Last two entries in column headed "Comments" should read, respectively: $\mathrm{Be}(\mathrm{OH})_{2}-\mathrm{UO}_{2}$ and $\mathrm{BeO}-\mathrm{UO}_{3}$.

121 \& Tables G5a, G5b, and G5c: Unit for column headed "Fission Burnup" should $122 \mathrm{read} a / 0 \mathrm{U}$.

127 Reference (2): First author should read: Stubbs, F. J. instead of Stubbs, T. J.

128 Table 1: Footnote (a) should be changed to read "Capsule probably leaked".

162 Table Gl: Add superscript (f) to Core-to-Cladding Ratio(f) column heading and add the following footnote:

(f) Ratio of core dimension to total cladding dimension for each indicated dimension.

194 Fourth line: Change "Table 2 contains" to "Tables $2 \mathrm{~A}$ and 2B contain".

195 Table 2: Change title to "Table 2A" and delete "Nominal" in Irradiation Temperature column heading. Add to the bottom of Table $2 \mathrm{~A}$ on page 195 the following footnotes:

(a) Listed in order of preparation in the case of multiple coatings.

(b) Rate of isotope release divided by rate of generation. Values listed are the release ratios at the end of the indicated time.

196 Table 2 (Continued): Delete entire page and replace with Table $2 \mathrm{~B}$.

197 Line 4, sixth paragraph: Replace "the" with "some" in the phrase "the pyrolyticcarbon-coated particles".

197 Last line of sixth paragraph should carry a citation for reference (8).

202 Add Reference (8): Oak Ridge National Laboratory, "Gas-Cooled Reactor Program Quarterly Progress Report for Period Ending December 31, 1961 ", ORNL-3254 (April 6, 1962), pp 161-165.

203 Volume Conversions: $\mathrm{ft}^{2}$ should be $\mathrm{ft}^{3}$.

204 Add the following conversion to list of fission units:

$\begin{gathered}\text { Fissions per } \\ \mathrm{cm}^{3} \text { of alloy }\end{gathered}=\left(\frac{\begin{array}{c}\text { atoms present } \\ \text { atomup of uranium }\end{array}}{100}\right)\left(\frac{\begin{array}{c}\text { o uranium in } \\ \text { the alloy }\end{array}}{100}\right)\left(\begin{array}{l}\text { density of } \\ \text { the alloy }\end{array}\right)\left(\begin{array}{l}6.02 \times 10^{23} \\ \left.\begin{array}{l}\text { atomic weight of } \\ \text { thanium } \\ \text { present }\end{array}\right)\end{array}\right.$

Note: Burnup is by fission.

Density, in $g$ per $\mathrm{cm}^{3}$, is the gross or macro density of the alloy and includes porosity. 
TABLE 2B. SUMMARY OF FISSION-GAS-RELEASE DATA FROM COATED-PARTICLE FUELS

\begin{tabular}{|c|c|c|c|c|c|c|c|c|c|c|}
\hline \multirow[b]{2}{*}{ Lot } & \multirow{2}{*}{$\begin{array}{c}\text { Fuel } \\
\text { Diameter } \\
\mu\end{array}$} & \multirow[b]{2}{*}{ Kind } & \multicolumn{2}{|c|}{ Coating } & \multirow{2}{*}{$\begin{array}{c}\text { Irradiation } \\
\text { Temperature, } \\
\text { C }\end{array}$} & \multirow{2}{*}{$\begin{array}{l}\text { Accumulated } \\
\text { Irradiation } \\
\text { Time, hr }\end{array}$} & \multirow{2}{*}{$\begin{array}{l}\text { Uranium } \\
\text { Burnup, } \\
\text { a/o }\end{array}$} & \multicolumn{3}{|c|}{$\mathrm{R} / \mathrm{B}$ at $820 \mathrm{~F}^{(\mathrm{a})}$} \\
\hline & & & $\begin{array}{c}\text { Thickness, } \\
\mu\end{array}$ & Kind & & & & $\mathrm{Kr}^{88}$ & $\frac{\mathrm{B} \text { at } 820 \mathrm{~F}}{\mathrm{Xe}^{135}}$ & $\mathrm{Xe}^{1.33}$ \\
\hline HTM-1 & 200 & $\mathrm{UC}_{2}$ & 82 & Col-PyC & $745-900$ & 1390 & 12.1 & $3 \times 10^{-5}$ & $6 \times 10^{-5}$ & $3 \times 10^{-4}$ \\
\hline $3 M-S P-2$ & 250 & $\mathrm{UC}_{2}$ & 82 & Lam-PyC & $620-990$ & 1510 & 14.9 & $2 \times 10^{-4}$ & $2 \times 10^{-4}$ & $5 \times 10^{-4}$ \\
\hline $\mathrm{NCC}-\mathrm{AD}$ & 300 & $\mathrm{UC}_{2}$ & 80 & Duplex-PyC & $315-925$ & 2110 & 14.7 & $4 \times 10^{-6}$ & $9 \times 10^{-6}$ & $3 \times 10^{-5}$ \\
\hline $3 M-101-U$ & 228 & $\mathrm{UC}_{2}$ & 0 & None & $500-820$ & 980 & 4.3 & $5 \times 10^{-3}$ & $1 \times 10^{-2}$ & $7 \times 10^{-2}$ \\
\hline
\end{tabular}

(a) Rate of release of isotope divided by rate of generation. 
UC-25 Metals, Ceramics, and Materials (TID-4500, 18th Ed.)

Contract No. W-7405-eng -92

\section{PROPER TIES OF FUELS \\ FOR \\ HIGH-TEMPERATURE REACTOR CONCEPTS}

\section{Edited by}

Roy W. Endebrock

Prepared at the request of Oak Ridge National Laboratories Gas-Cooled Reactor Program

November 1, 1962

BATTELLE MEMORIAL INSTITUTE 505 King Avenue

Columbus 1, Ohio 


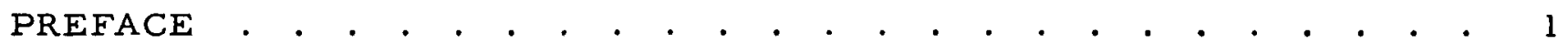

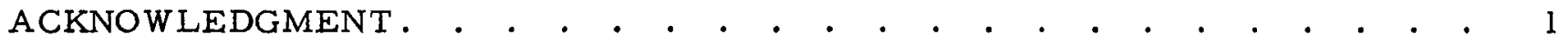

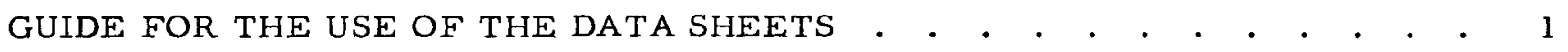

FUEL COMPARISON TABLE

ALLOYS

URANIUM ALLOYS - GENERAL • •

NIOBIUM-10 W/O URANIUM ALLOY

NIOBIUM-20 W/O URANIUM ALLOY

THORIUM-URANIUM ALLOYS - GENERAL . . • . . . . • . . $\quad 20$

COMPOUNDS

PLUTONIUM CARBIDE .

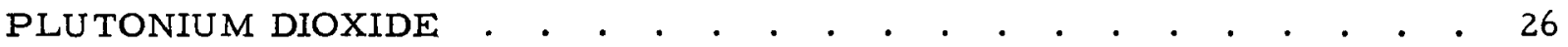

THORIUM URANIUM BORIDE . . . . . . . . . . . . . . . . . . 32

THORIUM URANIUM CARBIDE . . . . . . . . . . . . . . .36

THORIUM URANIUM DICARBIDE. . . . . . . . . . . . . . . . 40

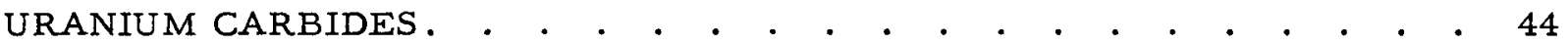

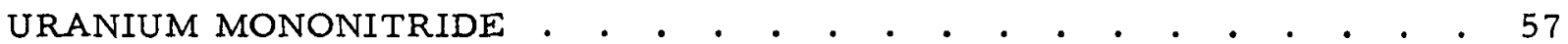

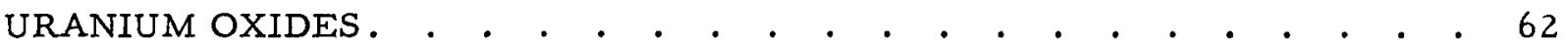

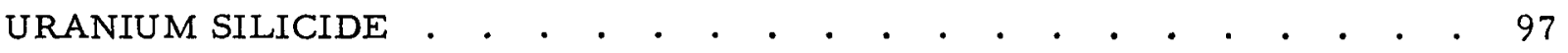

DISPERSIONS

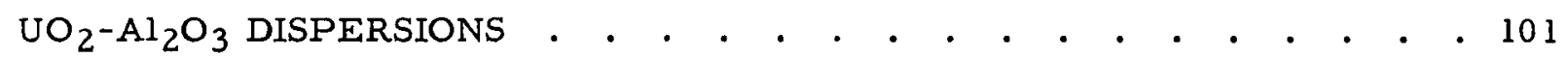

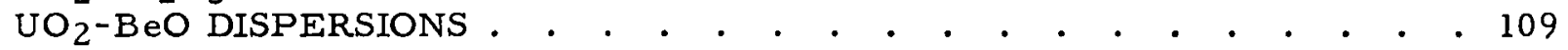

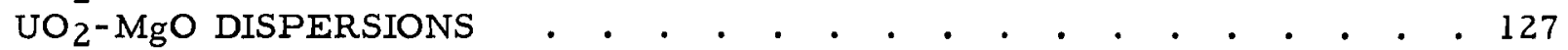

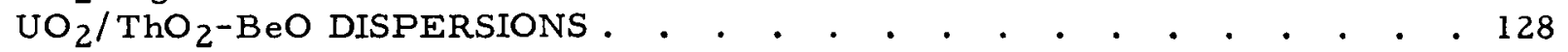

DISPERSIONS OF UNCOATED FUEL IN GRAPHITE. • . • . • • . $\quad$. 130

STAINLESS STEEL-UO 2 DISPERSION FUEL • • . . . . . . . • . . 156

CERMETS

UC CERMETS . . . . . . . . . . . . . . . . . . . . . . . 171

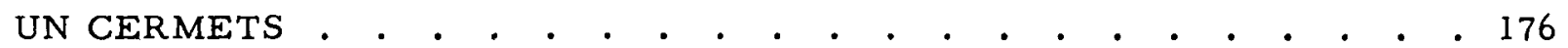

$\mathrm{UO}_{2}$ CERMETS . . . . . . . . . . . . . . . . . . . . . .

COATED-PARTICLE FUELS

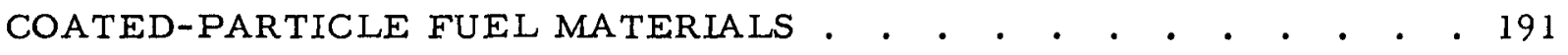

CONVERSION EQUIVALENTS . 


\section{PREFACE}

This compilation was prepared especially to aid design engineers in the selection of potential fuels for advanced high-temperature reactors. It was undertaken at the request of Oak Ridge National Laboratory in support of the ORNL Gas-Cooled Reactor Program. The compilation presents available data on critical properties for all fuels believed to be potentially capable of operating at surface temperatures of at least $650 \mathrm{C}$. Fuels of recent interest with this capability are included even though sufficient data for their final evaluation are not yet available.

The compilation is broken down into sections devoted to particular types of fuels. Property data for all these materials are arranged in a standardized format designed for rapid consultation. In addition to these data sheets, a master table that permits comparison of all fuels covered in the compilation on the basis of four properties considered essential in an initial fuel evaluation is presented. Also, a compilation of appropriate conversion units has been included for the design engineer's convenience.

\section{ACKNOW LEDGMENT}

The Editor wishes to express his gratitude to the Battelle personnel who assisted in the preparation of the sourcebook. Particularly appreciated were the efforts of the specialists who compiled the data sheets: M. C. Brockway, M. F. Browning, R. J. Burian, W. Chubb, J. A. De Mastry, M. S. Farkas, M. Kangilaski, D. L. Keller, D. E. Kizer, J. B. Melehan, N. E. Miller, J. H. Oxley, R. L. Ritzman, F. A. Rough, E. O. Speidel, D. L. Stoltz, V. W. Storhok, A. B. Tripler, and R. A. Wullaert. Grateful acknowledgment is made to J. J. Breslin for his as sistance in editing the manuscript. Invaluable, also, was the assistance given by ORNL personnel, especially by J. H. Coobs, G. Samuels, Jr., and A. E. Goldman.

\section{GUIDE FOR THE USE OF THE DATA SHEETS}

The format used in data sheets of the various fuels contained in this sourcebook was arranged so that the properties compiled for each fuel material are consistent and are presented in a standard code. In those instances where needed data are not yet available for a specific property, this lack of information is pointed out; however, where a particular property designation is not applicable to the material of interest, it is omitted. Any given letter-number combination identifies the same property throughout the sourcebook. The code employed is listed below:

A. Composition Limits

1. Chemical composition

2. Phase diagram

3. Effect of impurities 
B. Physical Properties

1. Density (room temperature)

2. Density versus temperature

3. Uranium or plutonium content*

4. Liquidus temperature

5. Solidus temperature

6. Vapor pressure

7. Thermal expansion (linear)

8. Recrystallization temperature range

C. Mechanical Properties

1. Hardness (room temperature)

2. Hot hardness

3. Ultimate tensile strength

4. Yield strength

5. Compressive strength

6. Creep strength

7. Young's modulus

8. Shear modulus

9. Bulk modulus, B $\mathrm{B}=\frac{\mathrm{E}}{3(1-2 \sigma)}$, where $\mathrm{E}=$ Young 's modulus and $\sigma=$ Poisson's ratio

10. Poisson's ratio

I1. Elongation

D. Thermal Properties

1. Specific heat

2. Thermal conductivity

\section{E. Electrical Properties}

1. Electrical resistivity

\section{F. Chemical Properties}

1. Reactions with coolants
a. Steam
b. Helium
c. Carbon dioxide
d. Nitrogen
e. Hydrogen
f. Liquid metals (limited to sodium, NaK, and lithium) g. Air

2. Reactions with claddings or structural materials

\footnotetext{
"Computed on the basis of the $\mathrm{U}^{238}$ or $\mathrm{Pu}^{239}$ to make application of the data to particular enrichments most convenient.
} 
3 and 4

G. Irradiation Properties

1. Dimensional stability during irradiation

2. Fission-gas-release data

3. Swelling-temperature data

4. Unusual nuclear properties

5. Property changes as a result of irradiation

H. References 
•

. 
5 and 6

FUEL COMPARISON TABLE

\begin{tabular}{|c|c|c|c|c|c|c|c|c|}
\hline \multirow[b]{2}{*}{ Fuel Material } & \multicolumn{2}{|c|}{$\begin{array}{c}\text { Contained Uranium or } \\
\text { Plutonium }\end{array}$} & \multicolumn{2}{|c|}{$\begin{array}{l}\text { Melting } \\
\text { Point }\end{array}$} & \multicolumn{3}{|c|}{$\begin{array}{l}\text { Thermal Conductivity, } \\
\mathrm{cal} /(\mathrm{sec})(\mathrm{cm})(\mathrm{C})\end{array}$} & \multirow{2}{*}{$\begin{array}{c}\text { Fission-to- } \\
\text { Absorption } \\
\text { Cross Section } \\
\text { Ratio }\end{array}$} \\
\hline & $\mathrm{w} / \mathrm{o}$ & $\mathrm{G}$ per $\mathrm{Cm}^{3}$ & $\mathrm{C}$ & $\mathrm{F}$ & At $20 \mathrm{C}$ & $\mathrm{At} 600 \mathrm{C}$ & At $1200 \mathrm{C}$ & \\
\hline \multicolumn{9}{|c|}{ Alloys } \\
\hline $\mathrm{Nb}-10 \mathrm{w} / \mathrm{OU}$ & $10 \mathrm{U}$ & $0.955(\mathrm{U})$ & 2400 & 4350 & - & 0.0936 & -- & 0.12 \\
\hline $\mathrm{Nb}-20 \mathrm{w} / \mathrm{OU}$ & $20 \mathrm{U}$ & $1.82(\mathrm{U})$ & 2300 & 4175 & -- & 0.0774 & $\cdots$ & 0.22 \\
\hline \multicolumn{9}{|c|}{ Compounds } \\
\hline PuC & $95.6-96.1 \mathrm{Pu}$ & 13.0 to $13.1(\mathrm{Pu})$ & 1650 & 3000 & - & -- & - & - \\
\hline $\mathrm{PuO}_{2}$ & $88.2 \mathrm{Pu}$ & $10.1(\mathrm{Pu})$ & 2280 & 4130 & $\cdots$ & $-\cdot$ & -- & $\cdots$ \\
\hline$\left(\mathrm{Th}_{9} \mathrm{U}\right) \mathrm{B}_{4}$ & $10 \mathrm{U}$ & $\cdots$ & $\cdots$ & -- & $\cdots$ & 0.891 & -- & -- \\
\hline$\left(\mathrm{Th}_{9} \mathrm{U}\right) \mathrm{C}$ & $10 \mathrm{U}$ & -- & - & -- & - & 0.0375 & -- & -- \\
\hline$\left(\mathrm{Th}_{9} \mathrm{U}\right) \mathrm{C}_{2}$ & $10 \mathrm{U}$ & $\cdots$ & $\cdots$ & -- & -- & 0.0566 & - & -- \\
\hline $\mathrm{UC}$ & $95.2 \mathrm{U}$ & $12.9(\mathrm{U})$ & 2400 & 4350 & 0.08 & 0.055 & 0.055 & 0.55 \\
\hline $\mathrm{UN}$ & $94.4 \mathrm{U}$ & $13.5(\mathrm{U})$ & 2630 & 4770 & 0.032 & 0.046 & 0.058 & 0.44 \\
\hline $\mathrm{UO}_{2}$ & $88.2 \mathrm{U}$ & $9.67(\mathrm{U})$ & 2760 & 5000 & 0.11 & $\sim 0.035$ & 0.022 & 0.55 \\
\hline $\mathrm{U}_{3} \mathrm{Si}_{2}$ & $86.2 \mathrm{U}$ & $11.3(\mathrm{U})$ & 1665 & 3030 & 0.035 & - & -- & 0.53 \\
\hline \multicolumn{9}{|c|}{ Ceramic Dispersions } \\
\hline $20 \mathrm{w} / \mathrm{o} \mathrm{UO} \mathrm{O}_{2}-80 \mathrm{w} / \circ \mathrm{Al}_{2} \mathrm{O}_{3}$ & $17.6 \mathrm{U}$ & $-\cdot$ & $\sim 2030$ & $\sim 3700$ & - & -- & -- & 0.33 \\
\hline $30 \mathrm{w} / 0 \mathrm{UO}_{2}-70 \mathrm{w} / \mathrm{o} \mathrm{Al}_{2} \mathrm{O}_{3}$ & $26.5 \mathrm{U}$ & -- & $\sim 2030$ & $\sim 3700$ & -- & $-\cdot$ & - & 0.45 \\
\hline $10 \mathrm{w} / \mathrm{o} \mathrm{UO}_{2}-90 \mathrm{w} / \mathrm{oBeO}$ & $8.8 \mathrm{U}$ & $0.26(\mathrm{U})$ & $\sim 2450$ & $\sim 4440$ & 0.25 & -- & -- & 0.48 \\
\hline $80 \mathrm{w} / \mathrm{\circ} \mathrm{\textrm {UO } _ { 2 }}-20 \mathrm{w} / \mathrm{OBe}$ & $70.6 \mathrm{U}$ & -- & - & - & -- & -- & -- & 0.53 \\
\hline $95 \mathrm{w} / \circ \mathrm{UO}_{2}-5 \mathrm{w} / \mathrm{O} \mathrm{MgO}$ & $83.8 \mathrm{U}$ & -- & -- & $\cdots$ & -- & -- & -- & 0.54 \\
\hline $\begin{array}{c}2.57 \mathrm{w} / \mathrm{o} \mathrm{UO}_{2}-7.3 \mathrm{w} / \mathrm{o} \\
\mathrm{ThO}_{2}-90 \mathrm{w} / \mathrm{oBeO}\end{array}$ & $2.24 \mathrm{U}$ & -- & -- & -- & -- & -- & -- & 0.13 \\
\hline $\begin{array}{c}25 \mathrm{w} / \mathrm{o} \mathrm{UO}_{2}-35.5 \mathrm{w} / \mathrm{o} \\
\mathrm{ThO}_{2}-39.1 \mathrm{w} / \mathrm{o} \mathrm{BeO}\end{array}$ & $22.1 \mathrm{U}$ & -- & -- & - & - & -- & - & 0.22 \\
\hline $\mathrm{UO}_{2}$-graphite & $19 \mathrm{U}$ & $0.38(\mathrm{U})$ & -- & -- & $\begin{array}{c}0.052 \text { to } \\
0.073\end{array}$ & -- & -- & 0.54 \\
\hline $\mathrm{UO}_{2}$-graphite & $45 \mathrm{U}$ & $1.21(\mathrm{U})$ & -- & -- & $\begin{array}{c}0.035 \text { to } \\
0.051\end{array}$ & -- & -- & 0.58 \\
\hline $\mathrm{UC}_{2}$-graphite & $10 \mathrm{U}$ & $0.19(\mathrm{U})$ & - & -- & $\sim 0.13$ & -- & -- & 0.51 \\
\hline $\mathrm{UC}_{2}$-graphite & $20 \mathrm{U}$ & $0.40(\mathrm{U})$ & $\cdots$ & -- & $\sim 0.14$ & -- & $\cdots$ & 0.53 \\
\hline \multicolumn{9}{|c|}{ Metallic Dispersions } \\
\hline $20 \mathrm{w} / \circ \mathrm{UO}_{2}$-stainless steel & $17.6 \mathrm{U}$ & $1.43(\mathrm{U})$ & $\begin{array}{c}1400 \text { to } \\
1460\end{array}$ & $\begin{array}{l}2550 \text { to } \\
2650\end{array}$ & 0.017 & 0.037 & 0.067 & 0.064 \\
\hline $40 \mathrm{w} / \circ \mathrm{UO}_{2}$-stainless steel & $35.3 \mathrm{U}$ & $3.06(\mathrm{U})$ & $\begin{array}{c}1400 \text { to } \\
1460\end{array}$ & $\begin{array}{l}2550 \text { to } \\
2650\end{array}$ & 0.022 & 0.028 & 0.034 & 0.13 \\
\hline $50 \mathrm{~W} / \circ \mathrm{UO}_{2}$-stainless steel & $44.1 \mathrm{U}$ & $3.95(\mathrm{U})$ & $\begin{array}{c}1400 \text { to } \\
1460\end{array}$ & $\begin{array}{c}2550 \text { to } \\
2650\end{array}$ & 0.022 & 0.027 & 0.032 & 0.18 \\
\hline \multicolumn{9}{|c|}{ Germets } \\
\hline Mo-80 volume per cent UC & $76.16 \mathrm{U}$ & $9.44(\mathrm{U})$ & 2625 & 4760 & 0.039 & 0.036 & 0.071 & 0.47 \\
\hline Mo-80 volume per cent UN & $75.55 \mathrm{U}$ & $9.79(\mathrm{U})$ & 2625 & 4760 & $\sim 0.05$ & 0.055 & -- & 0.39 \\
\hline Mo-80 volume per cent $\mathrm{UO}_{2}$ & $70.48 \mathrm{U}$ & $7.32(\mathrm{U})$ & 2625 & 4760 & $\sim 0.05$ & 0.045 & $-\cdot$ & 0.44 \\
\hline
\end{tabular}




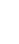

-

•. 


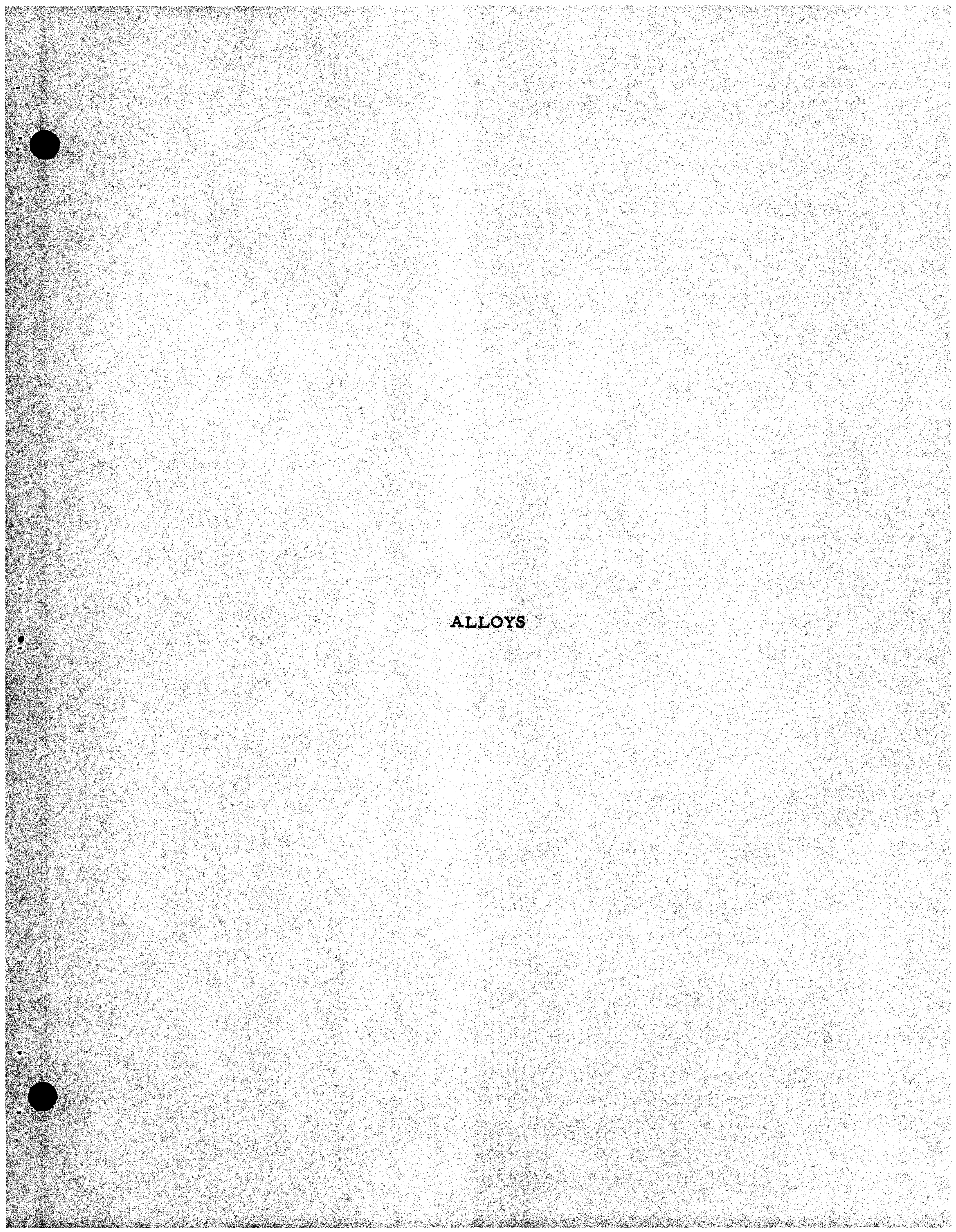




\title{
URANIUM ALLOYS - GENERAL
}

\author{
M. S. Farkas
}

The minimum surface temperature of $650 \mathrm{C}$ (indicating a center temperature of over $700 \mathrm{C}$ ) specified by ORNL eliminates uranium, alpha-phase uranium alloys, and most gamma-phase uranium alloys from consideration in this compilation.

Experimental data have shown that irradiation swelling occurs above about $500 \mathrm{C}$. 


\section{NIOBIUM-10 W/O URANIUM ALLOY}

Compiled by J. A. DeMastry

\section{Al. Chemical composition $(1)$}

Niobium-10 w/o uranium

\section{Phase diagram(2)}

The diagram shown in Figure $\mathrm{A} 2$ is from Rogers and Browne, and represents essential confirmation of work of earlier investigators, although revisions in certain boundaries have been made.

The complete solubility of gamma uranium and niobium is agreed on by all investigators, although there is disagreement as to the extent of the gamma ${ }_{1}$-plus-gamma 2 region. Sawyer reports the region as extending from about 11 to 78 a/o at $645 \mathrm{C}$, while Rogers and Browne report the monotectoid to occur at $16 \pm 1 \mathrm{a} / \mathrm{o}$ niobium and $645 \mathrm{C}$, but give values of 73 and $70 \mathrm{a} / \mathrm{o}$, respectively, for the niobium-rich limit of the gammal-plus-gamma 2 region at this temperature. Dwight reports the monotectoid as occurring at 19 a/o niobium and $634 \mathrm{C}$, the latter temperature being in agreement with its determination by Bauer.

On the basis of a tetragonal structure observed in quenched alloys containing 14 to 20 a/o niobium and thermal arrests ranging in temperature from 675 to $725 \mathrm{C}$ for alloys containing 9.6 to 17 a/o niobium, Dwight suggests an ordering of the gamma phase in the region of the monotectoid. While additional investigation is required, the tetragonal structure may be ascribed to a transition structure in the metastable-gamma decomposition.

There is some question concerning the nature of the alpha-to-beta transformation at the uranium-rich end of the system. Although most investigators agree that the reaction occurs peritectoidally, alpha has also been described as forming in a eutectoid reaction. A shift of less than $\pm 5 \mathrm{C}$ in the alpha-to-beta transition temperature is agreed to by all investigators.

Solubilities in the alpha and beta phase are reported to be extremely limited. Browne gives the maximum solubility in each phase as being between 1 and 2 a/o niobium.

3. Effect of impurities $(3)$

Oxygen in excess of $1000 \mathrm{ppm}$ results in increased tensile and creep strength and severe losses in ductility.

B1. Density (room temperature) ${ }^{(4)}$

$$
9.55 \mathrm{~g} \text { per } \mathrm{cm}^{3}
$$

\section{Density versus temperature}

No data available

\section{Uranium content}

$$
0.955 \mathrm{~g} \text { per } \mathrm{cm}^{3}
$$




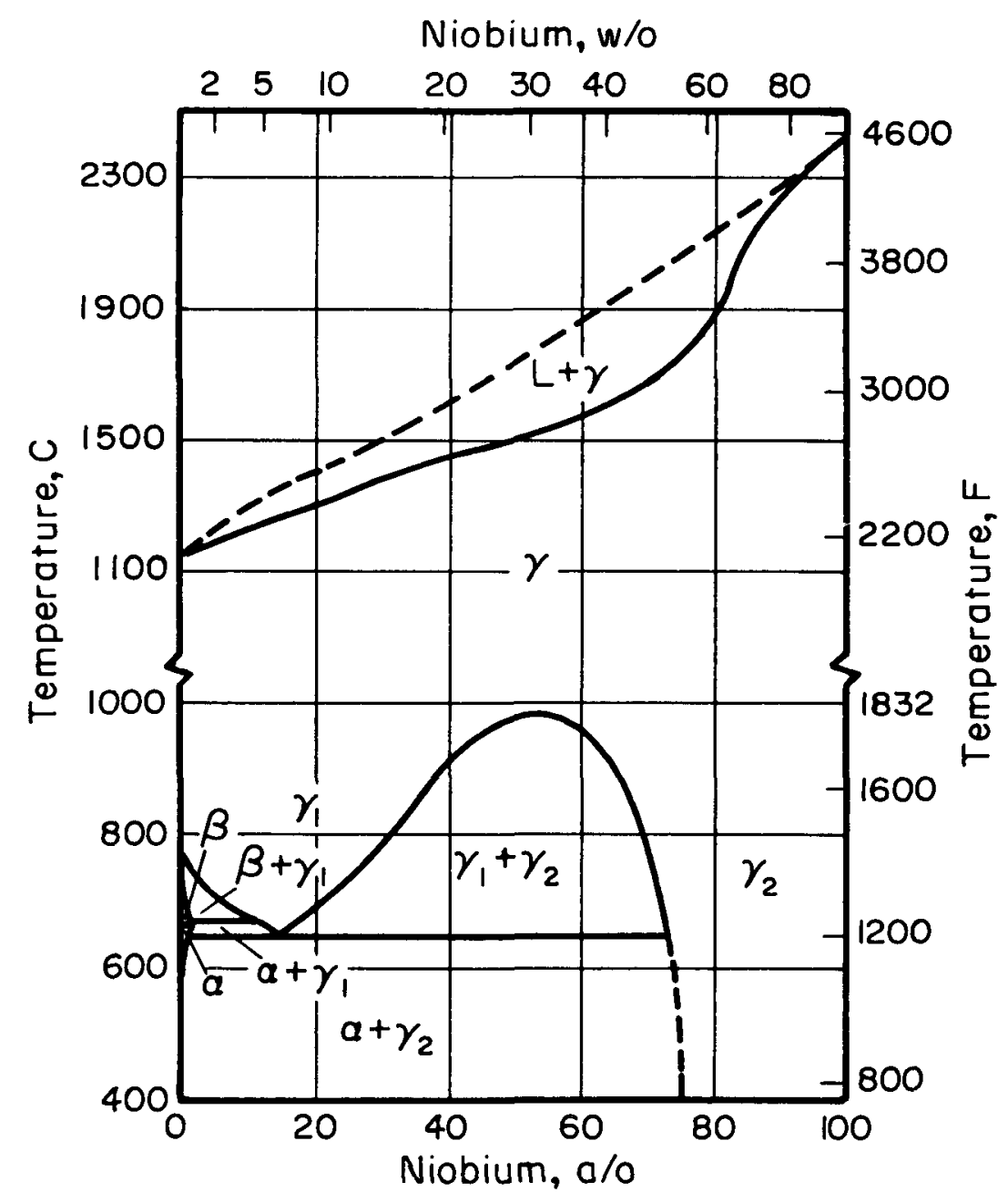

FIGURE A2. URANIUM-NIOBIUM PHASE DIAGRAM ${ }^{(2)}$ 
4. Liquidus temperature (2)

$$
2400 \pm 50 \mathrm{C}
$$

5. Solidus temperature $(2)$

$2400 \pm 50 \mathrm{C}$

6. Vapor pressure

No data available

7. Thermal expansion (linear) ${ }^{(3)}$

\section{Temperature, $\mathbf{F}$}

$68-200$

$200-400$

400-600

$600-800$

$800-1000$

$1000-1200$

$1200-1400$

$1400-1600$

$1600-1800$

$68-1800$

8. Recrystallization temperature range ${ }^{(4)}$

1100 to $1200 \mathrm{C}$

Cl. Hardness (room temperature) ${ }^{(1)}$

$164 \mathrm{~kg}$ per $\mathrm{mm}^{2}$

2. Hot hardness (1)

Temperature, C
400
500
600
700
800
900
1000
1100

3. Ultimate tensile strength $(1,3)$

Temperature, $\mathbf{F}$

68

1600

1800

2000

2200

(a) Alloy contained 3100 ppm oxygen.

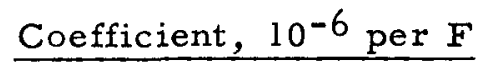

4.1

4.1

4.3

4.5

4.8

4.9

5.0

5.2

5.2

4.7

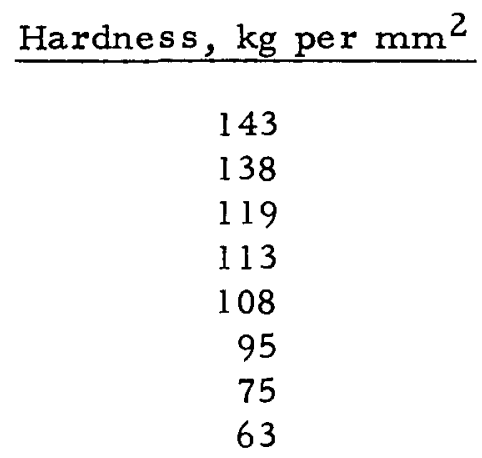

Ultimate Tensile Strength, psi(a)

72,900

72,000

52,000

35,000

24,000 
4. Yield strength $(1,3)$

\begin{tabular}{cr} 
Temperature, $F$ & Yield Strength \\
\hline 68 & 55,900 \\
1800 & 45,000 \\
2000 & 25,000
\end{tabular}

5. Compressive strength

No data available

6. Creep strength $(3)$

\begin{tabular}{|c|c|c|c|c|c|}
\hline \multicolumn{4}{|c|}{ Stress for Creep Rate Shown, psi } & \multicolumn{2}{|c|}{ Rupture Data } \\
\hline $\begin{array}{c}\text { Temperature, } \\
F\end{array}$ & $\begin{array}{c}0.001 \mathrm{Per} \\
\text { Cent per } \mathrm{Hr}\end{array}$ & $\begin{array}{c}0.01 \text { Per } \\
\text { Cent per Hr } \\
\end{array}$ & $\begin{array}{c}0.1 \text { Per } \\
\text { Cent per } \mathrm{Hr}\end{array}$ & $\begin{array}{c}\text { Stress, } \\
\text { psi } \\
\end{array}$ & $\begin{array}{c}\text { Rupture Time, } \\
\mathrm{hr}\end{array}$ \\
\hline 1600 & 17,000 & 25,000 & 37,000 & $\begin{array}{l}30,000 \\
25,000\end{array}$ & $\begin{array}{l}602 \\
381\end{array}$ \\
\hline 1800 & 8,800 & 12,000 & 15,000 & $\begin{array}{l}20,000 \\
14,000\end{array}$ & $\begin{array}{l}28.9 \\
54\end{array}$ \\
\hline
\end{tabular}

Note: Alloy contained 3100 ppm oxygen which accounts for unusual strength.

7. Young's modulus

No data available

8. Shear modulus

No data available

9. Bulk modulus

No data available

10. Poisson's ratio

No data available

11. Elongation $(1,3)$

\begin{tabular}{cr}
$\begin{array}{c}\text { Temperature, } \\
\text { F }\end{array}$ & $\begin{array}{r}\text { Elongation in } 1-\text { In } \\
\text { (Flat Specimen }\end{array}$ \\
\cline { 2 - 2 } 68 & 3 \\
1600 & 1 \\
1800 & 4 \\
2000 & 9 \\
2200 & 10
\end{tabular}

Note: Alloy contained 3100 ppm oxygen.

D1. Specific heat

No data available 
2. Thermal conductivity (3)

\begin{tabular}{|c|}
\hline $\begin{array}{c}\text { Temperature, } \\
F\end{array}$ \\
\hline 200 \\
\hline 400 \\
\hline 600 \\
\hline 800 \\
\hline 1000 \\
\hline 1200 \\
\hline 1400 \\
\hline 1600 \\
\hline 1800 \\
\hline
\end{tabular}
Thermal Conductivity, $\mathrm{Btu} /(\mathrm{hr})(\mathrm{ft})(\mathrm{F})$
14.0
16.0
18.0
19.9
21.7
23.6
25.4
27. 1
28. 7

E1. Electrical resistivity $(3)$

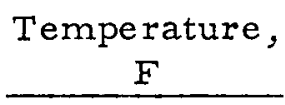

68

200

400

600

800

1000

1200
Resistivity, microhm-cm

36

39

43

47

51

54

57

F1. Reactions with coolants
a. Steam (1)

Minus $13.3 \mathrm{mg}$ per $\mathrm{cm}^{2}$ in $1000 \mathrm{hr}$ at $750 \mathrm{~F}$ (399 C)

b. Helium(4)

No attack after $100 \mathrm{hr}$ at $1800 \mathrm{~F}(982 \mathrm{C})$

c. Carbon dioxide(l)

Plus $0.23 \mathrm{mg}$ per $\mathrm{cm}^{2}$ in $50 \mathrm{hr}$ at $600 \mathrm{~F}(982 \mathrm{C})$

d. Nitrogen

No data available

e. Hydrogen

No data available

f. Liquid metals (3)

Plus $0.15 \mathrm{mg}$ per $\mathrm{cm}^{2}$ in sodium in $1500 \mathrm{hr}$ at $1500 \mathrm{~F}(816 \mathrm{C})$

Plus $0.14 \mathrm{mg}$ per $\mathrm{cm}^{2}$ in $\mathrm{NaK}$ in $1000 \mathrm{hr}$ at $1600 \mathrm{~F}(871 \mathrm{C})$

g. $\operatorname{Air}(1)$

Plus $2.34 \mathrm{mg}$ per $\mathrm{cm}^{2}$ in $100 \mathrm{hr}$ at $750 \mathrm{~F}(400 \mathrm{C})$ 
2. Reactions with claddings or structural materials

No data available

G1. Dimensional stability during irradiation ${ }^{(4)}$

Minus 2. 1 per cent change in density, $5.6 \times 10^{20}$ fission per $\mathrm{cm}^{3}, 1200 \mathrm{~F}$

Minus 2.3 per cent change in density, $2.8 \times 10^{20}$ fission per $\mathrm{cm}^{3}, 1900 \mathrm{~F}$

2. Fission-gas-release data

No data available

3. Swelling-temperature data

No data available

4. Unusual nuclear properties

No data available

5. Property changes os a result of irradiation

No data available

H. References

(1) De Mastry, J. A., Shober, F. R., and Dickerson, R. F., "Metallurgical Studies of Niobium-Uranium Alloys", BMI-1400 (December 7, 1959).

(2) Rough, F. A., and Bauer, A. A., "Constitution of Uranium and Thorium Alloys", BMI-1300 (June 2, 1958).

(3) De Mastry, J. A., Moak, D. P., Epstein, S. G., Bauer, A. A., and Dickerson, R. F., "Development of Niobium-Uranium Alloys for Elevated-Temperature Fuel Applications", BMI-1536 (August 9, 1961).

(4) De Mastry, J. A., Unpublished Data. 


\title{
NIOBIUM-20 W /O URANIUM ALLOY
}

\author{
Compiled by J. A. DeMastry
}

A1. Chemical composition (1)

Niobium-20 w/o uranium

2. Phase diagram (2)

The diagram shown in Figure B2 is from Rogers and Browne, and represents essential confirmation of work of earlier investigators, although revisions in certain boundaries have been made.

The complete solubility of gamma uranium and niobium is agreed on by all investigators, although there is disagreement as to the extent of the gamma ${ }_{1}$-plus-gamma 2 region. Sawyer reports the region as extending from about 11 to 78 a/o at $645 \mathrm{C}$, while Rogers and Browne report the monotectoid to occur at $16 \pm 1$ a/o niobium and $645 \mathrm{C}$, but give values of 73 and 70 a/o, respectively, for the niobium-rich limit of the gamma 1 -plusgamma $_{2}$ region at this temperature. Dwight reports the monotectoid as occurring at 19 a/o niobium and $634 \mathrm{C}$, the latter temperature being in agreement with its determination by Bauer.

On the basis of a tetragonal structure observed in quenched alloys containing 14 to 20 a/o niobium and thermal arrests ranging in temperature from 675 to $725 \mathrm{C}$ for alloys containing 9.6 to 17 a/o niobium, Dwight suggests an ordering of the gamma phase in the region of the monotectoid. While additional investigation is required, the tetragonal structure may be ascribed to a transition structure in the metastable-gamma decomposition.

There is some question concerning the nature of the alpha-to-beta trans formation at the uranium-rich end of the system. Although most investigators agree that the reaction occurs peritectoidally, alpha has also been described as forming in a eutectoid reaction. A shift of less than $\pm 5 \mathrm{C}$ in the alpha-to-beta transition temperature is agreed to by all investigators.

Solubilities in the alpha and beta phase are reported to be extremely limited. Browne gives the maximum solubility in each phase as being between 1 and 2 a/o niobium.

\section{Effect of impurities $(3)$}

Oxygen in excess of $1000 \mathrm{ppm}$ results in increased tensile and creep strength and severe losses in ductility.

B 1. Density (room temperature) $)^{(4)}$

9. $1 \mathrm{~g}$ per $\mathrm{cm}^{3}$

2. Density versus temperature

No data available

3. Uranium content

$1.82 \mathrm{~g}$ per $\mathrm{cm}^{3}$ 


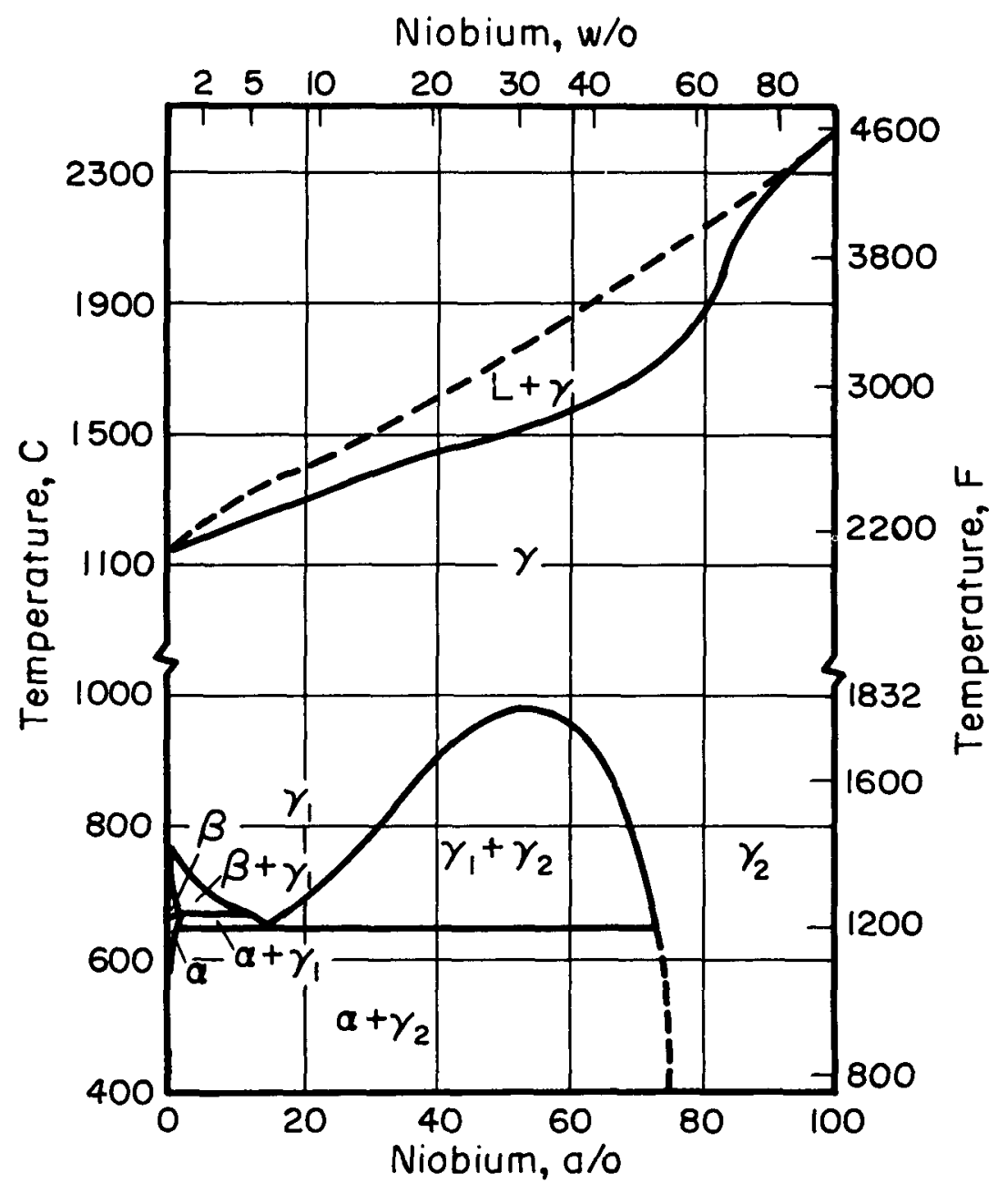

FIGURE A2. URANIUM-NIOBIUM PHASE DIAGRAM (2) 
4. Liquidus temperature (2)

$$
2325 \pm 50 \mathrm{C}
$$

5. Solidus temperature ${ }^{(2)}$

$$
2325 \pm 50 \mathrm{C}
$$

6. Vapor pressure

No data available

7. Thermal expansion(3)

Temperature, $\mathbf{F}$

$$
\begin{array}{r}
68-200 \\
200-400 \\
400-600 \\
600-800 \\
800-1000 \\
1000-1200 \\
1200-1400 \\
1400-1600 \\
1600-1800 \\
68-1800
\end{array}
$$

8. Recrystallization temperature range ${ }^{(4)}$

$$
1100 \text { to } 1200 \mathrm{C}
$$

Cl. Hardness (room temperafure) $(1)$

$$
213 \mathrm{~kg} \text { per } \mathrm{mm}^{2}
$$

2. Hot hardness (1)

Temperature, C
400
500
600
700
800
900
1000
1100

3. Ultimate tensile strength $(1,3)$

Temperature, $\mathbf{F}$
68
1600
1800
2000

Coefficient, $10^{-6}$ per $F$
4.2
4.4
4.6
4.7
5.0
5.1
5.3
5.5
5.7
5.0

163

155

145

143

140

133

113

92 
4. Yield strength $(1,3)$

Temperature, $F$

68

1600

1800

2000
Yield Strength, psi

93,000

58,000

43,000

29,000

5. Compressive strength

No data available

6. Creep strength $(3)$

\begin{tabular}{|c|c|c|c|c|c|}
\hline \multirow[b]{2}{*}{$\begin{array}{c}\text { Temperature, } \\
F \\
\end{array}$} & \multicolumn{3}{|c|}{ Stress for Creep Rate Shown, psi } & \multicolumn{2}{|c|}{ Rupture Data } \\
\hline & $\begin{array}{c}0.001 \text { Per } \\
\text { Cent per Hr }\end{array}$ & $\begin{array}{c}0.01 \text { Per } \\
\text { Cent per Hr }\end{array}$ & $\begin{array}{c}0.1 \text { Per } \\
\text { Cent per } \mathrm{Hr}\end{array}$ & $\begin{array}{l}\text { Stress, } \\
\text { psi } \\
\end{array}$ & $\begin{array}{c}\text { Rupture Time, } \\
\mathrm{hr}\end{array}$ \\
\hline 1600 & 17,000 & 25,000 & 37,000 & 30,000 & 38.7 \\
\hline 1800 & 8,800 & 11,500 & 15,000 & $\begin{array}{l}20,000 \\
51,000\end{array}$ & $\begin{array}{r}27.2 \\
169.7\end{array}$ \\
\hline
\end{tabular}

7. Young's modulus

No data available

8. Shear modulus

No data available

9. Bulk modulus

No data available

10. Poisson's ratio

No data available

11. Elongation $(1,3)$

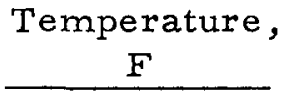

68

1600

1800

2000
Elongation in l-In. Gage Length, per cent

\section{7}

10

34

74

D1. Specific heat

No data available 
2. Thermal conductivity $(3)$

\begin{tabular}{c}
$\begin{array}{c}\text { Temperature, } \\
\text { F }\end{array}$ \\
\hline 200 \\
400 \\
600 \\
800 \\
1000 \\
1200 \\
1400 \\
1600 \\
1800
\end{tabular}
Thermal Conductivity, $\mathrm{Btu} /(\mathrm{hr})(\mathrm{ft})(\mathrm{F})$

10.2

11.8

13.6

15.5

17.6

19.8

22. 2

24.6

27.2

E1. Electrical resistivity (3)

Temperature,
$F$

$\overline{68}$

68

200

400

600

800

1000

1200
Resistivity, $\underline{\text { microhm-cm }}$

54

56

59

63

66

68

71

F1. Reactions with coolants

a. Steam (1)

Minus 2. $45 \mathrm{mg}$ per $\mathrm{cm}^{2}$ in $1000 \mathrm{hr}$ at $750 \mathrm{~F}(400 \mathrm{C})$

b. Helium (4)

No attack after $100 \mathrm{hr}$ at $1800 \mathrm{~F}(980 \mathrm{C})$

c. Carbon dioxide( 1 )

Plus $0.13 \mathrm{mg}$ per $\mathrm{cm}^{2}$ in $50 \mathrm{hr}$ at $600 \mathrm{~F}(315 \mathrm{C})$

d. Nitrogen

No data available

e. Hydrogen

No data available

f. Liquid metals

Plus $0.10 \mathrm{mg}$ per $\mathrm{cm}^{2}$ in sodium in $1500 \mathrm{hr}$ at $1500 \mathrm{~F}(815 \mathrm{C})$

Plus $0.69 \mathrm{mg}$ per $\mathrm{cm}^{2}$ in $\mathrm{NaK}$ in 1000 at $1600 \mathrm{~F}(870 \mathrm{C})$

g. $\operatorname{Air}(1)$

Plus $20.0 \mathrm{mg}$ per $\mathrm{cm}^{2}$ in $100 \mathrm{hr}$ at $750 \mathrm{~F}(400 \mathrm{C})$ 
2. Reactions with claddings or structural materials

No data available

G1. Dimensional stability during irradiation(4)

Minus 2.5 per cent change in density, $5.0 \times 10^{20}$ fissions per $\mathrm{cm}^{3}, 1200 \mathrm{~F}$

Minus 1.7 per cent change in density, $2.49 \times 10^{20}$ fissions per $\mathrm{cm}^{3}, 1900 \mathrm{~F}$

2. Fission-gas-release dato

No data available

3. Swelling-temperature data

No data available

4. Unusual nuclear properties

No data available

5. Property chonges as a result of irradiation

No data available

H. References

(1) DeMastry, J. A., Shober, F. R., and Dickerson, R. F., "Metallurgical Studies of Niobium-Uranium Alloys", BMI-1400 (December 7, 1959).

(2) Rough, F. A., and Bauer, A. A., "Constitution of Uranium and Thorium Alloys", BMI-1300 (June 2, 1958).

(3) DeMastry, J. A., Moak, D. P., Epstein, S. G., Bauer, A. A., and Dickerson, R. F., "Development of Niobium-Uranium Alloys for Elevated-Temperature Fuel Applications", BMI-1536 (August 9, 1961).

(4) DeMastry, J. A., Unpublished Data. 


\section{THORIUM-URANIUM ALLOYS - GENERAL}

\section{S. Farkas}

The specification of a minimum surface-temperature of $650 \mathrm{C}$ eliminates thoriumuranium alloys from consideration for ORNL high-temperature reactor concepts.

Little information on irradiation swelling exists, but there are strong indications that the limiting temperature for known alloys is below the 650 to $700 \mathrm{C}$ minimum service temperature limitation. One study has shown that thorium-11 w/o uranium swells at $650 \mathrm{C}^{*}$.

Reactor Core Materials, 3 (1), 8 (February, 1960). 
COMPOUNDS 


\section{PLUTONIUM CARBIDE}

Compiled by V. W. Storhok

A1. Chemical composition (1)

PuC, 95.22 w/o plutonium, 4.78 w/o carbon

2. Phase diagram $(1)$

See Figure A2

3. Effect of impurities

No data available

B1. Density (room temperature) (2)

$13.6 \mathrm{~g} \mathrm{per} \mathrm{cm}^{3}$

2. Density versus temperature

No data available

3. Plutonium content

13.0 to $13.1 \mathrm{~g}$ per $\mathrm{cm}^{3}$

4. Liquidus temperature ${ }^{(1)}$

$\sim 1800 \mathrm{C}$

5. Solidus temperature $(1)$

$1654 \mathrm{C}$

6. Vapor pressure

No data available

7. Thermal expansion (linear) $(3)$

$10 \times 10^{-6}$ per $\mathrm{C}$ from RT to $900 \mathrm{C}$ (presumed from text of reference)

8. Recrystallization temperature range

No data available

C1. Hardness (room temperature) $)^{(4)}$

Carbon, a/o

44.4

47.1

50.4
$\underline{\mathrm{DPH}}$

480

700

770

2. Hot hardness

No data available

3. Ultimate tensile strength

No data available 


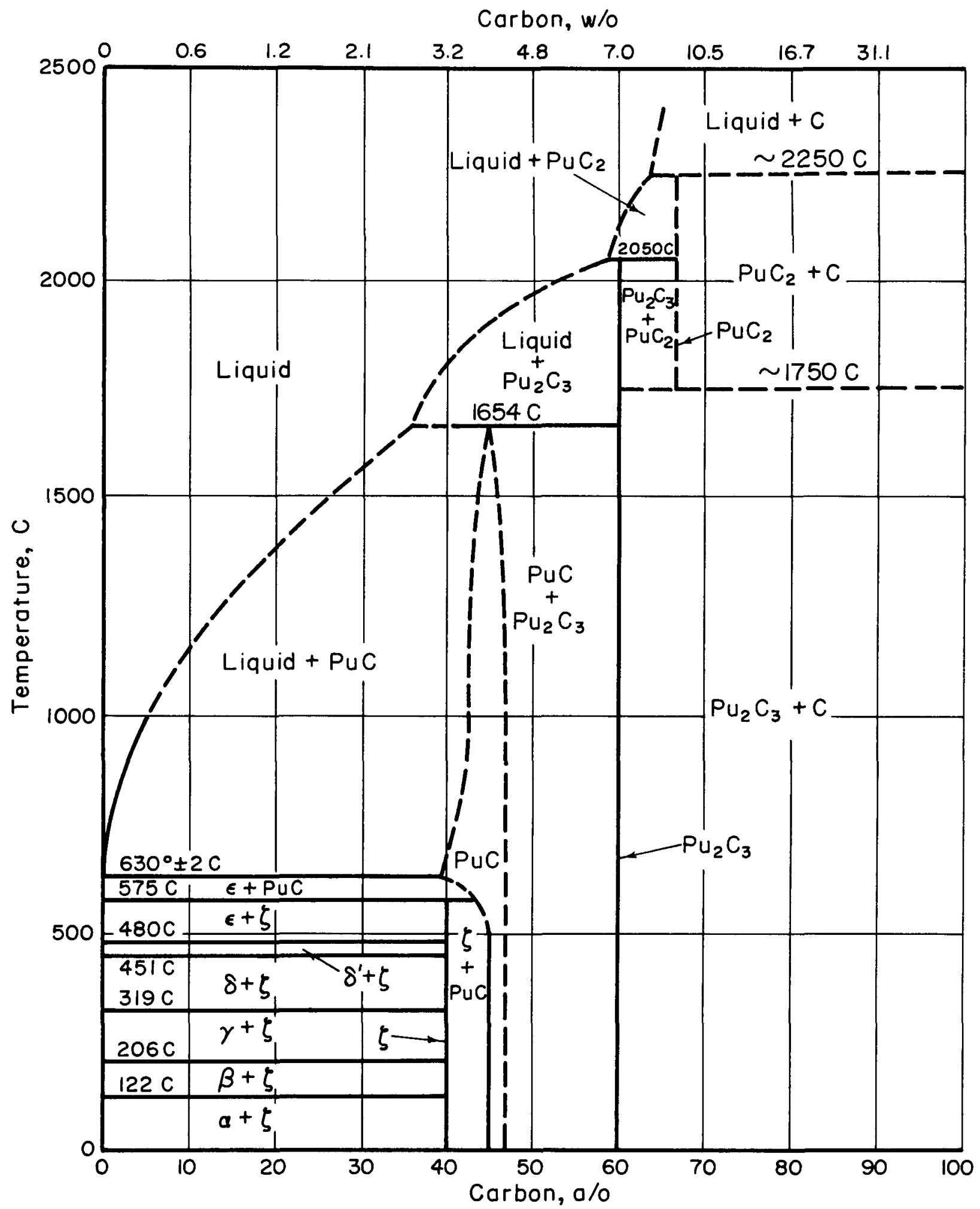

FIGURE A2. PLUTONIUM - CARBON PHASE DIAGRAM (1) 
4. Yield strength

No data available

5. Compressive strength

No data available

6. Young's modulus

No data available

7. Shear modulus

No data available

8. Bulk modulus

No data available

9. Poisson's ratio

No data available

10. Elongation

No data available

Di. Specific heat

No data available

2. Thermal conductivity

No data available

E1. Electrical resistivity $(5)$

$266 \mathrm{microhm}-\mathrm{cm}$

\section{F1. Reactions with coolants}

\section{a. Steam $(6)$}

Probably very rapid attack - effervesces in hot water, producing methane and hydrogen.

b. Helium

Apparently no reaction at room temperature, as helium is often employed as PuC glove-box atmosphere; no high-temperature data.

c. Carbon dioxide

No data available

d. Nitrogen

No data available

e. Hydrogen

No data available

f. Liquid metals

$\mathrm{NaK}(4)$

Apparently compatible to at least $430 \mathrm{C}$ 


$$
\begin{aligned}
& \text { g. Air (7) } \\
& \quad \text { Oxidizes slowly at } 300 \mathrm{C}
\end{aligned}
$$

2. Reactions with claddings or structural materials

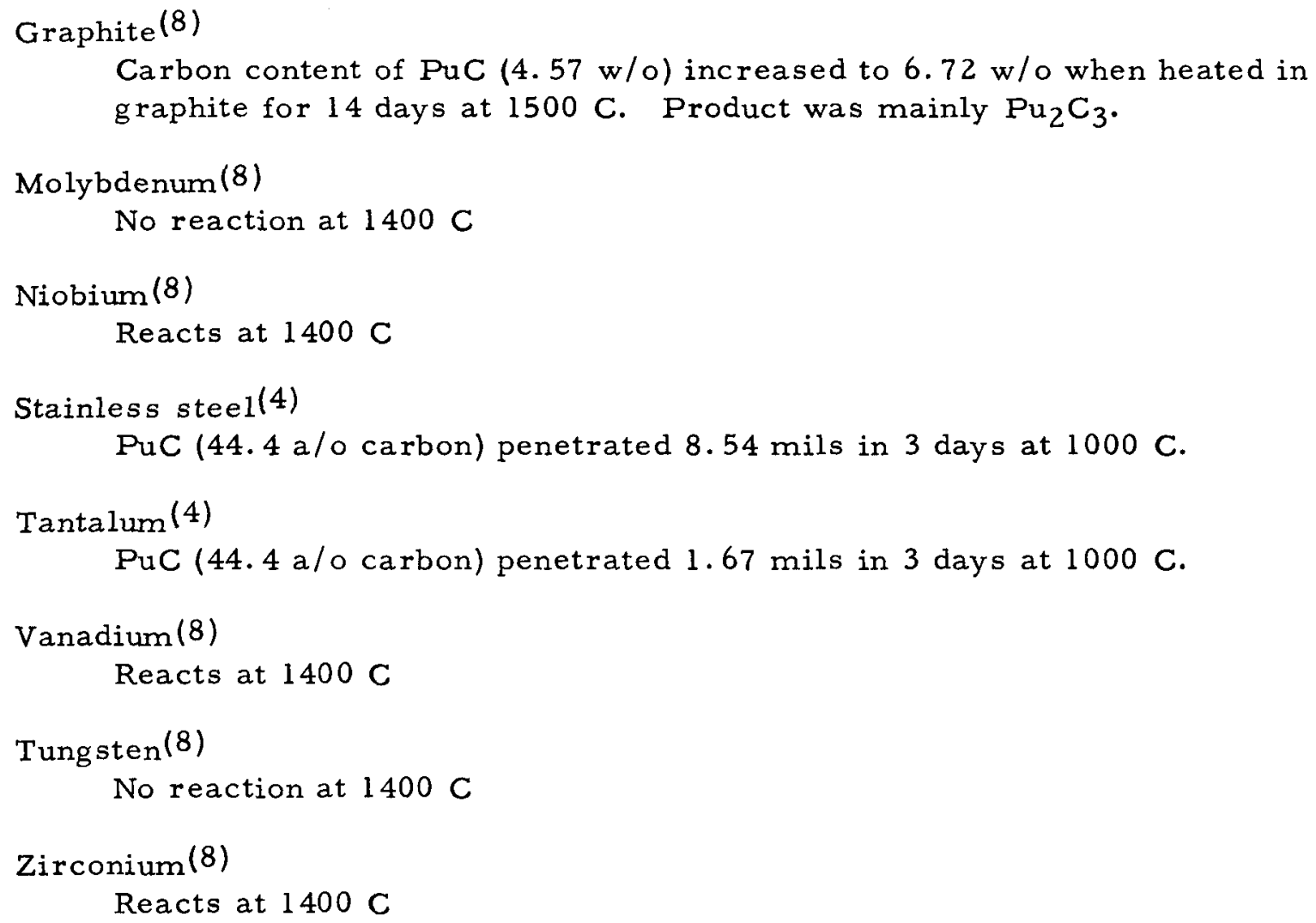

G1. Dimensional stability during irradiation $(9)$

Of four specimens irradiated to a burnup of $3.28 \times 10^{19}$ fissions per $\mathrm{cm}^{3}$ at a maximum central temperature of $430 \mathrm{C}$, three decreased in density with the maximum decrease being 1.44 per cent. One specimen cracked.

\section{Fission-gas-release data}

No data available

3. Swelling-temperature data

No data available

4. Unusual nucleor properties

No data available

\section{Property changes as a result of irradiation}

No data available

\section{H. References}

(1) Mulford, R. N. R., Ellinger, F. H., Hendrix, G. S. , and Albrecht, E. D. , "The Plutonium-Carbon System", Plutonium 1960, Edited by Grison, E., Lord, W. B. H., and Fowler, R. D., Cleaver-Hume Press Ltd., London, pp 301-311. 
(2) Coffinberry, A. S., Schonfeld, F. W. , Waber, J. T., Kelman, C. R., and Tipton, C. R., Jr., "Plutonium and Its Alloys", Reactor Handbook, Materials, 2nd Edition, Edited by Tipton, C. R. , Jr., Interscience Publishers, New York (1960), pp 248-290.

(3) "Reactor Development Program Progress Report, August, 1960", ANL-6215 (September 16, 1960).

(4) "Metallurgy Division Annual Report for 1960", ANL-6330.

(5) Unpublished LASL Data.

(6) Drummong, J. L., McDonald, B. J., Dikenden, H. M., and Welch, G. A., "The Preparation and Properties of Some Plutonium Compounds, Part VII Plutonium Carbides", J. Chem. Soc., pp 4785 (December, 1957).

(7) Strasser, A., "Uranium Carbide As a Fuel, A Revision of Current Knowledge", Nuclear Eng., 5 (51), 353-357 (August, 1960).

(8) Waldren, M., Unpublished U. K. Data.

(9) Hilberry, N., "Reactor Development Program Progress Report", ANL-6355 (April, 1961). 


\section{PLUTONIUM DIOXIDE}

Compiled by V. W. Storhok

A1. Chemical composition (1)

$\mathrm{PuO}_{2}, 88.19$ w/o plutonium, $11.81 \mathrm{w} / \mathrm{o}$ oxygen

2. Phase diagram (1)

See Figure A2

3. Effect of impurities

No data available

B 1. Density (room temperature) $)^{(2)}$

$11.46 \mathrm{~g}$ per $\mathrm{cm}^{3}$

2. Density versus temperature

No data available

3. Plutonium content

$10.1 \mathrm{~g}$ per $\mathrm{cm}^{3}$

4. Liquidus temperature ${ }^{(3)}$

$2280 \pm 30 \mathrm{C}$ (pseudomelting temperature)

5. Solidus temperature $(3)$

$2280 \pm 30 \mathrm{C}$ (pseudomelting temperature)

6. Vapor pressure ${ }^{(4)}$

\begin{tabular}{cccc} 
Temperature, & \multicolumn{3}{c}{ Vapor Pressure, atm } \\
\cline { 3 - 3 } & Oxygen & Argon & Air \\
\cline { 3 - 4 } 1450 & -- & $2.1 \times 10^{-9}$ & $1.1 \times 10^{-9}$ \\
1500 & $5.0 \times 10^{-10}$ & -- & $3.1 \times 10^{-9}$ \\
1525 & -- & $4.4 \times 10^{-9}$ & -- \\
1550 & $8.9 \times 10^{-10}$ & $3.1 \times 10^{-9}$ & -- \\
1575 & $9.9 \times 10^{-10}$ & -- & -- \\
1600 & $2.0 \times 10^{-9}$ & $5.3 \times 10^{-9}$ & $1.3 \times 10^{-8}$ \\
1650 & $2.1 \times 10^{-9}$ & $1.7 \times 10^{-8}$ & $6.4 \times 10^{-9}$ \\
1675 & -- & $1.1 \times 10^{-8}$ & -- \\
1700 & $2.8 \times 10^{-9}$ & $8.7 \times 10^{-9}$ & $2.0 \times 10^{-8}$ \\
1725 & $1.9 \times 10^{-8}$ & $1.3 \times 10^{-8}$ & -- \\
1750 & $1.6 \times 10^{-8}$ & $2.7 \times 10^{-8}$ & -- \\
1775 & $3.8 \times 10^{-8}$ & -- & $3.8 \times 10^{-8}$
\end{tabular}

Conclusions: (1) $\mathrm{PuO}_{2}$ congruently vaporizes in oxygen.

(2) $\mathrm{PuO}_{2}$ vaporizes as $\mathrm{PuO}_{2}(\mathrm{~g})+\mathrm{PuO}(\mathrm{g})$ in neutral gases. 


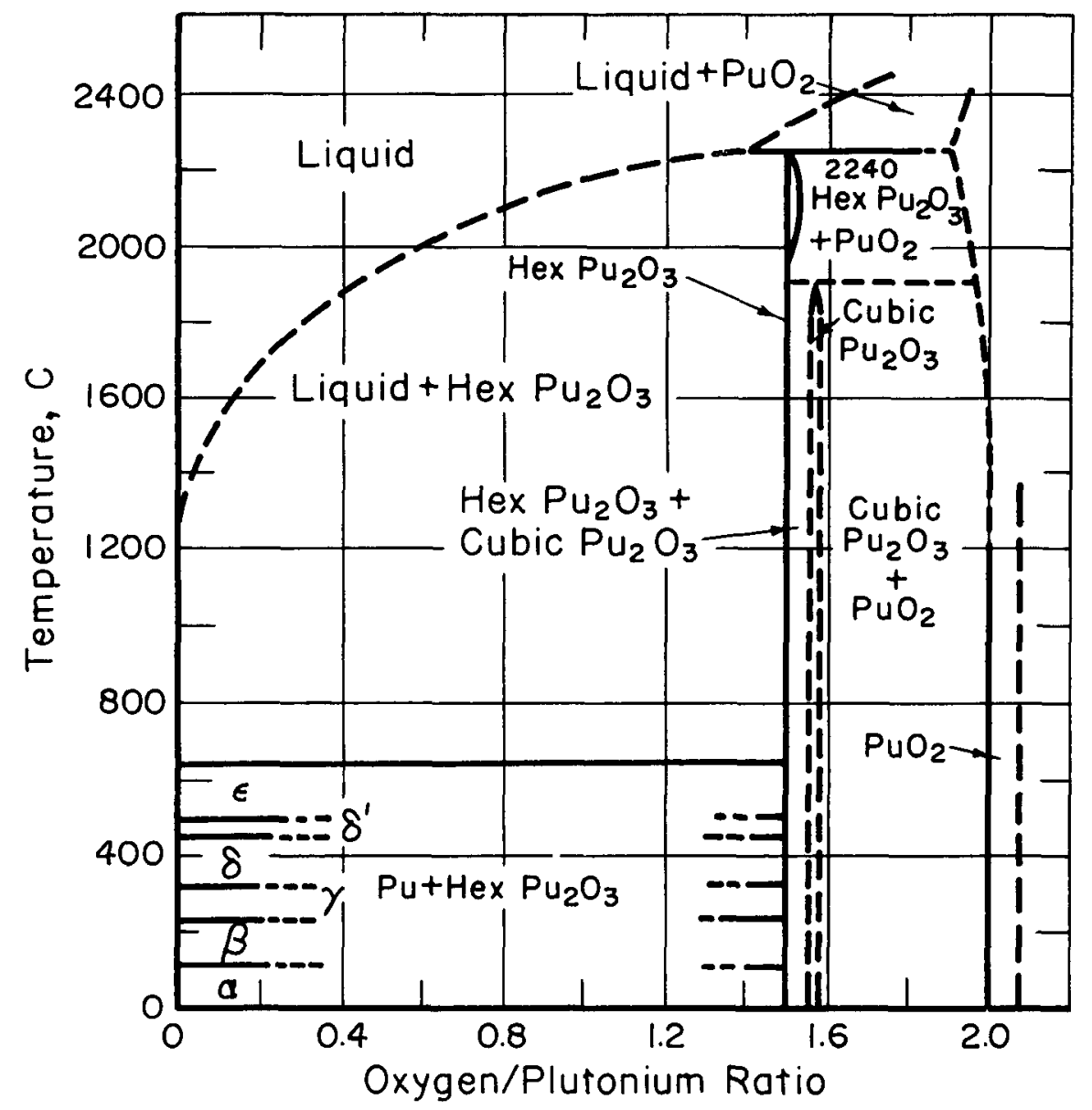

FIGURE A2. PLUTONIUM-OXYGEN SYSTEM ${ }^{(1)}$ 
7. Thermal expansion (linear) $(5)$

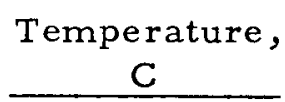

20-300

20-600

20-800

$20-1000$

\section{Coefficient, $10^{-6}$ per $C$}
8. 2
9.9
10.5
11.4

8. Recrystallization temperature range No data available

C1. Hardness (room temperature)

No data available

2. Hot hardness

No data available

3. Ultimate tensile strength

No data available

4. Yield strength

No data available

5. Compressive strength

No data available

6. Creep strength

No data available

7. Young's modulus

No data available

8. Shear modulus

No data available

9. Bulk modulus

No data available

10. Poisson's ratio

No data available

11. Elongation

No data available

D1. Specific heat

No data available

2. Thermal conductivity No data available 


\section{E1. Electrical resistivity}

No data available

\section{F1. Reactions with coolants}

\section{a. Steam}

No data available

b. Helium(6)

Slight reduction of $\mathrm{PuO}_{2}$ occurs to yield oxygen-to-plutonium ratio of about 1.97 .

c. Carbon Dioxide(7)

Apparently no serious reaction occurs, as $\mathrm{CO}_{2}$ has been employed as a sintering atmosphere at temperatures up to $1650 \mathrm{C}$.

d. Nitrogen

No data available

e. Hydrogen (6)

$\mathrm{PuO}_{2}$ begins to reduce to $\mathrm{Pu}_{2} \mathrm{O}_{3}$ at about $1400 \mathrm{C}$.

f. Liquid metals

$\operatorname{NaK}(8)$

Apparently compatible to at least $680 \mathrm{C}$

g. $\operatorname{Air}(6)$

Lower oxides to $\mathrm{PuO}_{2} .00$ at temperatures as low as $200 \mathrm{C}$.

\section{Reactions with claddings or structural materials}

Iron and austenitic stainless steel(9)

Slight reduction of $\mathrm{PuO}_{2}$ to $\mathrm{Pu}_{2} \mathrm{O}_{3}$ occurs after $100 \mathrm{hr}$ at $1400 \mathrm{C}$.

Inconel (10)

No reaction up to $1370 \mathrm{C}$

Chromium (10)

No reaction up to $1370 \mathrm{C}$

Molybdenum(10)

No reaction up to $1370 \mathrm{C}$

Niobium(9)

Slight reduction of $\mathrm{PuO}_{2}$ to $\mathrm{Pu}_{2} \mathrm{O}_{3}$ curves after $100 \mathrm{hr}$ at $1400 \mathrm{C}$.

Titanium (10)

Reacts at $1370 \mathrm{C}$

Tungsten $(10)$

Reacts at $1370 \mathrm{C}$ 
Vanadium (10)

No reaction at $1370 \mathrm{C}$

Zircaloy $-2(10)$

Reacts at $1370 \mathrm{C}$

$\mathrm{Al}_{2} \mathrm{O}_{3}$

Reacts at $1590 \mathrm{C}$

$\mathrm{MgO}(10)$

No reaction at $1590 \mathrm{C}$

$\mathrm{ZrO}_{2}(10)$

Alloyed at $1590 \mathrm{C}$

G1. Dimensional stability during irradiation

See Table G1.

2. Fission-gas-release data

See Table Gl.

3. Swelling-temperature data

No data available

TABLE G1. EFFECTS OF IRRADIATION(a) $\mathrm{ON} \mathrm{PuO}_{2}-40 \mathrm{w} / \mathrm{o} \mathrm{U}^{235} \mathrm{O}_{2}-40 \mathrm{w} / \mathrm{o} \mathrm{U}^{238} \mathrm{O}_{2}{ }^{(8)}$

\begin{tabular}{|c|c|c|c|c|c|c|}
\hline \multirow[b]{2}{*}{$\begin{array}{l}\text { Burnup (b), } 10^{20} \\
\text { fissıons per } \mathrm{cm}^{3}\end{array}$} & \multirow{2}{*}{$\begin{array}{c}\text { Maximum } \\
\text { Surface }^{(c)}, \mathrm{C} \\
\text { Temperature }^{(\mathrm{c})}, \mathrm{C}\end{array}$} & \multirow{2}{*}{$\begin{array}{c}\text { A verage Heat } \\
\text { Flux, } 10^{6} \\
\left.\text { Btu/(hr)(ft }{ }^{2}\right)\end{array}$} & \multirow{2}{*}{$\begin{array}{c}\text { Fission - } G \text { as } \\
\text { Release, } \\
\text { per cent }\end{array}$} & \multirow{2}{*}{$\begin{array}{c}\text { Length } \\
\text { Increase, } \\
\text { per cent }\end{array}$} & \multicolumn{2}{|c|}{ Central Vold Formation } \\
\hline & & & & & $\begin{array}{l}\text { Per Cent of } \\
\text { Cross Section }\end{array}$ & $\begin{array}{c}\text { Per Cent of } \\
\text { Postirradiation Length }\end{array}$ \\
\hline $1.93(\mathrm{~d})$ & 468 & 0.37 & 27.8 & 11.2 & No vold & -- \\
\hline $2.67(\mathrm{e})$ & 532 & 0.55 & 52.4 & 4.2 & 4 to 5.4 & $>43$ \\
\hline $3.96(d)$ & 435 & 0.36 & 71.3 & 0 & 3.0 & 15 \\
\hline $5.98(\mathrm{e})$ & 621 & 0.54 & 49.6 & 4.0 & No vold & $-\infty$ \\
\hline $20.3(e)$ & 638 & 1.30 & 28.8 & 5.7 & 2 to 4 & 51 \\
\hline $20.3^{(d)}$ & 680 & 1.27 & 48.1 & 9.0 & 9.8 to 19.5 & 75 \\
\hline
\end{tabular}

(a) Irradiation properties of $\mathrm{PuO}_{2}$ should be reasonably similar.

(b) Calculated assuming $9000 \mathrm{MWD} / 2000 \mathrm{lb}$ of plutonıum and uranıum $=2.47 \times 10^{20}$ fissions per $\mathrm{cm}^{3}$ in the fuel material.

(c) No central temperature given.

(d) Swaged specimen.

(e) Pelletızed specimen.

4. Unusual nuclear properties

No data available

5. Property changes as a result of irradiation

No data avilable 
(1) Schonfeld, F. W., "Plutonium Phase Diagrams Studied at Los Alamos", The Metal Plutonium, Edited by Coffinberry, A. S. , and Miner, W. N., University of Chicaro Press, pp 241-254 (1961).

(2) Coffinberry, A. S., Schonfeld, F. W., Waber, J. T., Kelman, C. R. , and Tipton, C. R., Jr., "Plutonium and Its Alloys", Reactor Handbook, Materials, 2nd Edition, Edited by Tipton, C. R., Jr., Interscience Publishers, New York, pp 248-290 (1960).

(3) Chikalla, T. D., "The Liquidus for the System $\mathrm{UO}_{2}-\mathrm{PuO}_{2}$ ", HW-69832 (June, 1961).

(4) Pardue, W. M., unpublished BMI data.

(5) Arthur, G., "Ceramics Properties", Nuclear Eng. , 6, 253-257 (June 1, 1961).

(6) Goldsmith, S., Editor, "Plutonium Recycle Program Annual Report, Fiscal Year 1961", HW-70000 (August 11, 1961).

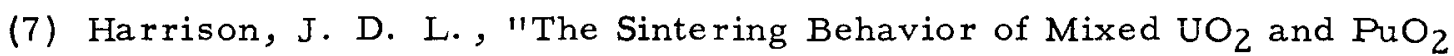
Powders", AERE-R-3765 (July, 1961).

(8) Gerhart, J. M., Siltanen, J. H., and Cochran, J. S., "The Irradiation and Examination of a Plutonium Uranium Oxide Fast Reactor Fuel", Symposium on Radiation Effects in Refractory Fuel Compounds, ASTM Special Technical Publication No. 306 (1962).

(9) Poole, D. M., Critchly, J. K., Davidson, J. A. C., French, P. M., Hodkin, E. N., and Notley, M. J. F., "Properties of Some Plutonium Fuels", Plutonium 1960, Edited by Grison, E., Lord, W. B. H. , and Fowler, R. D., Cleaver-Hume Press, Ltd, London (1961), pp 627-649.

(10) Paprocki, S. J., Keller, D. L., and Pardue, W. M., "The Chemical Reactivity of $\mathrm{PuO}_{2}$ with Reactor Materials", BMI-1580 (May 29, 1962). 


\title{
THORIUM URANIUM BORIDE
}

\section{Compiled by J. A. DeMastry}

\begin{abstract}
A1. Chemical composition
$(\mathrm{Th}, \mathrm{U}) \mathrm{B}_{4}$
\end{abstract}

2. Phase diagram

No data available

3. Effect of impurities

No data available

B1. Density (room temperature)

No data available

2. Density versus temperature

No data available

3. Uranium content

No data available

4. Liquidus temperature

No data available

5. Solidus temperature

No data available

6. Vapor pressure

No data available

7. Thermal expansion (linear) $(1)$

\section{Temperature, $F$}

$68-200$

$68-400$

$68-600$

$68-800$

$68-1000$

$68-1200$

$68-1400$

$68-1600$

$68-1800$
Coefficient, $10^{-6}$ per $F$

3. 5

3.7

3.8

4.0

4. 1

4. 2

4. 3

4. 3

4. 4

8. Recrystallization temperature range No data available

Cl. Hardness (room temperature) ${ }^{(2)}$

2700 Knoop (100-g load) 
C2. Hot hardness

No data available

3. Ultimate tensile strength

No data available

4. Yield strength

No data available

5. Compressive strength $(1,3)$

Temperature, $\mathbf{F}$

1200

1800

6. Creep strength

No data available

7. Young's modulus

No data available

8. Shear modulus

No data available

9. Bulk modulus

No data available

10. Poisson's ratio

No data available

11. Elongation

No data available

D1. Specific heat

No data available

2. Thermal conductivity $(4)$

Temperature, $\mathrm{C}$

400

600

800

900

El. Electrical resistivity

No data available
Compressive Strength, psi

45,000

48,000

33,000
Thermal Conductivity, $\mathrm{cal} /(\mathrm{s} \mathrm{ec})(\mathrm{cm})(\mathrm{C})$
0.0652
0.0731
0.0810
0.0891
0.0932 
F1. Reactions with coolants
a. Steam
No data available
b. Helium
No data available
c. Carbon Dioxide(2)
Plus $0.03 \mathrm{mg} /\left(\mathrm{cm}^{2}\right)(\mathrm{hr})$ at $590 \mathrm{C}$
d. Nitrogen
No data available
e. Hydrogen
No data available
f. Liquid metals
No data available
g. $\operatorname{Air}(5)$

Temperature,
F
1100
1600
1700
2100
2200
Total Weight Gain in $24 \mathrm{Hr}$, $\mathrm{mg}$ per $\mathrm{cm}^{2}$
0.42
4.8
6.8
14.5
24.6

2. Reactions with claddings or structural materials No data available

G1. Dimensional stability during irradiation

No data available

2. Fission-gas-release data

No data available

3. Swelling-temperature data

No data available

4. Unusual nuclear properties

No data available

5. Property changes was a result of irradiation

No data available 
H. References

(1) Dayton, R. W. , and Tipton, C. R., Jr., "Progress Relating to Civilian Applications During January, 1962", BMI-1565 (February 1, 1962).

(2) Farkas, M. S., Bauer, A. A., and Dickerson, R. F., "Evaluation of Thorium and Thorium-Uranium Compounds As Thermal Breeder Fuels", BMI-1568 (February 15, 1962).

(3) Dayton, R. W., and Dickerson, R. F., "Progress Relating to Civilian Applications During February, 1962", BMI-1569 (March 1, 1962).

(4) Dayton, R. W., and Dickerson, R. F., "Progress Relating to Civilian Applications During July, 1962", BMI-1589 (August 1, 1962).

(5) Dayton, R. W., and Dickerson, R. F., "Progress Relating to Civilian Applications During March, 1962", BMI-1574 (April 1, 1962). 


\section{THORIUM URANIUM CARBIDE}

Compiled by J. A. DeMastry

Al. Chemical composition

$\left(\mathrm{Th}_{9} \mathrm{U}\right) \mathrm{C}$

2. Phase diagram

No data available

3. Effect of impurities

No data available

B 1. Density (room temperature)

No data available

2. Density versus temperature

No data available

3. Uranium content

No data available

4. Liquidus temperature

No data available

5. Solidus temperature

No data available

6. Vapor pressure

No data available

7. Thermal expansion (linear) $(1)$

Temperature, $F$

$68-200$

$68-400$

$68-600$

$68-800$

$68-1000$

$68-1200$

$68-1400$

$68-1600$

$68-1800$
Coefficient, $10^{-6}$ per $F$

3.5

3.6

3.6

3. 8

3. 8

3. 9

3. 9

4. 1

4. 1

8. Recrystallization temperature range No data available

C1. Hardness (room temperature) ${ }^{(2)}$

520 Knoop (100-g load) 
C2. Hot hardness

No data available

3. Ultimate tensile strength

No data available

4. Yield strength

No data available

5. Compressive strength $(1,3)$

Temperature, $F$

68

1200

1800

6. Creep strength

No data available

7. Young's modulus

No data available

8. Shear modulus

No data available

9. Bulk modulus

No data available

10. Poisson's rotio

No data available

11. Elongation

No data available

D1. Specific heat

No data available

2. Thermal conductivity ${ }^{(4)}$

Temperature, $\mathrm{C}$

200

400

600

800

900

1000

\section{Compressive Strength, psi}

$$
\begin{aligned}
& 23,000 \\
& 17,000 \\
& 67,000
\end{aligned}
$$

Thermal Conductivity, $\mathrm{cal} /(\mathrm{sec})(\mathrm{cm})(\mathrm{C})$
0.0308
0.0342
0.0375
0.0411
0.0426
0.0442

E1. Electrical resistivity

No data available 
F1. Reoctions with coolants
a. Steam (2)
Catastrophic
b. Helium
No data available
c. Carbon dioxide
No data available

d. Nitrogen

No data available

e. Hydrogen

No data available

f. Liquid metals $(2)$

Minus $4.5 \times 10^{-2} \mathrm{mg} /\left(\mathrm{cm}^{2}\right)($ day $)$ at $1200 \mathrm{~F}$ in $\mathrm{NaK}$.

g. $\operatorname{Air}(2)$

Dry: plus $17 \mathrm{mg} /\left(\mathrm{cm}^{2}\right)(\mathrm{hr})$ at $1300 \mathrm{~F}$

Wet: catastrophic

F2. Reactions with claddings or structural materials

No data available

G1. Dimensional stability during irradiation

No data available

2. Fission-gas-release data

No data available

3. Swelling-temperature data

No data available

4. Unusual nuclear properties

No data available

5. Property changes as a result of irradiation

No data available

H. References

(1) Dayton, R. W., and Tipton, C. R., Jr., "Progress Relating to Civilian Applications During January, 1962", BMI-1565 (February 1, 1962).

(2) Farkas, M. S., Bauer, A. A., and Dickerson, R. F., "Evaluation of Thorium and Thorium-Uranium Compounds as Thermal Breeder Fuels", BMI-1568 (February 15, 1962). 
(3) Dayton, R. W. , and Dickerson, R. F., "Progress Relating to Civilian Applications During February, 1962", BMI-1569 (March 1, 1962).

(4) Dayton, R. W., and Dickerson, R. F., "Progress Relating to Civilian Applications During July, 1962", BMI-1589 (August 1, 1962). 


\section{THORIUM URANIUM DICARBIDE}

\section{Compiled by J. A. DeMastry}

Al. Chemical composition

$$
\text { ( } \left.\mathrm{Th}_{\mathrm{g}} \mathrm{U}\right) \mathrm{C}_{2}
$$

2. Phase diagram

No data available

3. Effect of impurities

No data available

B1. Density (room temperature)

No data available

2. Density versus temperature

No data available

3. Uranium content

No data available

4. Liquidus temperature

No data available

5. Solidus temperature

No data available

6. Vapor pressure

No data available

7. Thermal expansion (linear) (1)

\section{Temperature, $F$}

$68-200$

$68-400$

$68-600$

$68-800$

$68-1000$

$68-1200$

$68-1400$

$68-1600$

68-1800
Coefficient, $10^{-6}$ per $\mathrm{F}$

4. 1

4. 2

4. 3

4. 4

4. 4

4.6

4.7

4.8

5.0

8. Recrystallization temperafure range No data available

Cl. Hardness (room temperature) ${ }^{(2)}$ 460 Knoop (100-g load) 
2. Hot hardness

No data available

3. Ultimate tensile strength

No data available

4. Yield strength

No data available

5. Compressive strength $(1,3)$

Temperature, $\mathrm{F}$

68

1200

1800

6. Creep strength

No data available

7. Young's modulus

No ciata available

8. Sheor modulus

No data available

9. Bulk Modulus

No data available

10. Poisson's ratio

No data available

11. Elongation

No data available

D1. Specific heat

No data available

2. Thermal conductivity ${ }^{(4)}$

Temperature, C

200

400

600

800

900

950
Compressive Strength, psi

59,000

15,000

23,000
Thermal Conductivity, $\mathrm{cal} /(\mathrm{sec})(\mathrm{cm})(\mathrm{C})$

0.0483

0.0528

0.0566

0.0607

0.0629

0.0637

\section{El. Electrical resistivity}

No data available 
F1. Reactions with
a. Steam $(2)$
Catastrophic
b. Helium
No data available
c. Carbon dioxide
No data available
d. Nitrogen
No data available
e. Hydrogen
No data available
f. Liquid metals (2)
Minus $1.5 \times 10^{-2} \mathrm{mg} /\left(\mathrm{cm}^{2}\right)$ (day) in $1200 \mathrm{~F} \mathrm{NaK}$
g. $\operatorname{Air}(2)$
Dry: plus $17 \mathrm{mg} /\left(\mathrm{cm}^{2}\right)(\mathrm{hr})$ at $1300 \mathrm{~F}$
Wet: catastrophic

2. Reactions with claddings or structural materials

No data available

G1. Dimensional stability during irradiation

No data available

2. Fission-gas-release data

No data available

3. Swelling-temperature data

No data available

4. Unusual nuclear properties

No data available

5. Property changes as a result of irradiation

No data available

H. References

(1) Dayton, R. W., and Tipton, C. R., Jr., "Progress Relating to Civilian Applications During January, 1962, BMI-1565 (February 1, 1962).

(2) Farkas, M. S., Bauer, A. A., and Dickerson, R. F., "Evaluation of Thorium and Thorium-Uranium Compounds As Thermal Breeder Fuels", BMI-1568 (February 15, 1962). 
(3) Dayton, R. W. , and Dickerson, R. F., "Progress Relating to Civilian Applications During February, 1962", BMI-1569 (March 1, 1962).

(4) Dayton, R. W. , and Dickerson, R. F., "Progress Relating to Civilian Applications During August, 1962", BMI-1593 (September 1, 1962). 


\section{URANIUM CARBIDES}

Compiled by W. Chubb

A1. Chemical composition

Uranium monocarbide, UC, $4.8 \mathrm{w} / \mathrm{o}$ carbon

Uranium sesquicarbide, $\mathrm{U}_{2} \mathrm{C}_{3}, 7.0 \mathrm{w} / \mathrm{o}$ carbon

Uranium dicarbide, $\mathrm{UC}_{2}, 9.1 \mathrm{w} / \mathrm{o}$ carbon

\section{Phase diagram (1)}

See Figure A2.

\section{Effect of impurities}

The melting point of UC is lowered by all known impurities except HfC, $\mathrm{NbC}$, TaC, ThC, UN, and ZrC. See Reference (2) for additional details of ternary constitution.

Most impurities tend to increase the room-temperature hardness and strength of UC.

\section{B1. Density (room temperature)}

As-cast uranium-carbon alloys (3): see Figure Bl.

$\mathrm{U}_{2} \mathrm{C}_{3}: 12.8 \mathrm{~g}$ per $\mathrm{cm}^{3}$. (4)

\section{Density versus temperature}

No data available: see B-7.

3. Uranium content

Compound

UC

$\mathrm{U}_{2} \mathrm{C}_{3}$
Fuel Density, g per $\mathrm{cm}^{3}$

12.9

11.9

10.2

4. Liquidus temperature

See Figure A2.

5. Solidus temperature

See Figure A2.

6. Vapor pressure $(5,6)$

The vapor species over uranium carbides are not known precisely. A congruently vaporizing composition exists at approximately $\mathrm{UC}_{1.07}$. Higher carbon alloys lose carbon preferentially by vaporization. Assuming the vapor species over $\mathrm{UC}_{2}$ saturated with carbon (actually about $\mathrm{UC}_{1.86}$ ) to be uranium atoms and carbon atoms, the following expressions for the vapor pressure of uranium have been obtained:

From 1930 to $2365 \mathrm{~K}^{(5)}$ :

$$
\ln P_{U}=-\frac{67,164}{T}-0.111\left(\ln T+\frac{2000}{T}\right)+12.140 \text {. }
$$




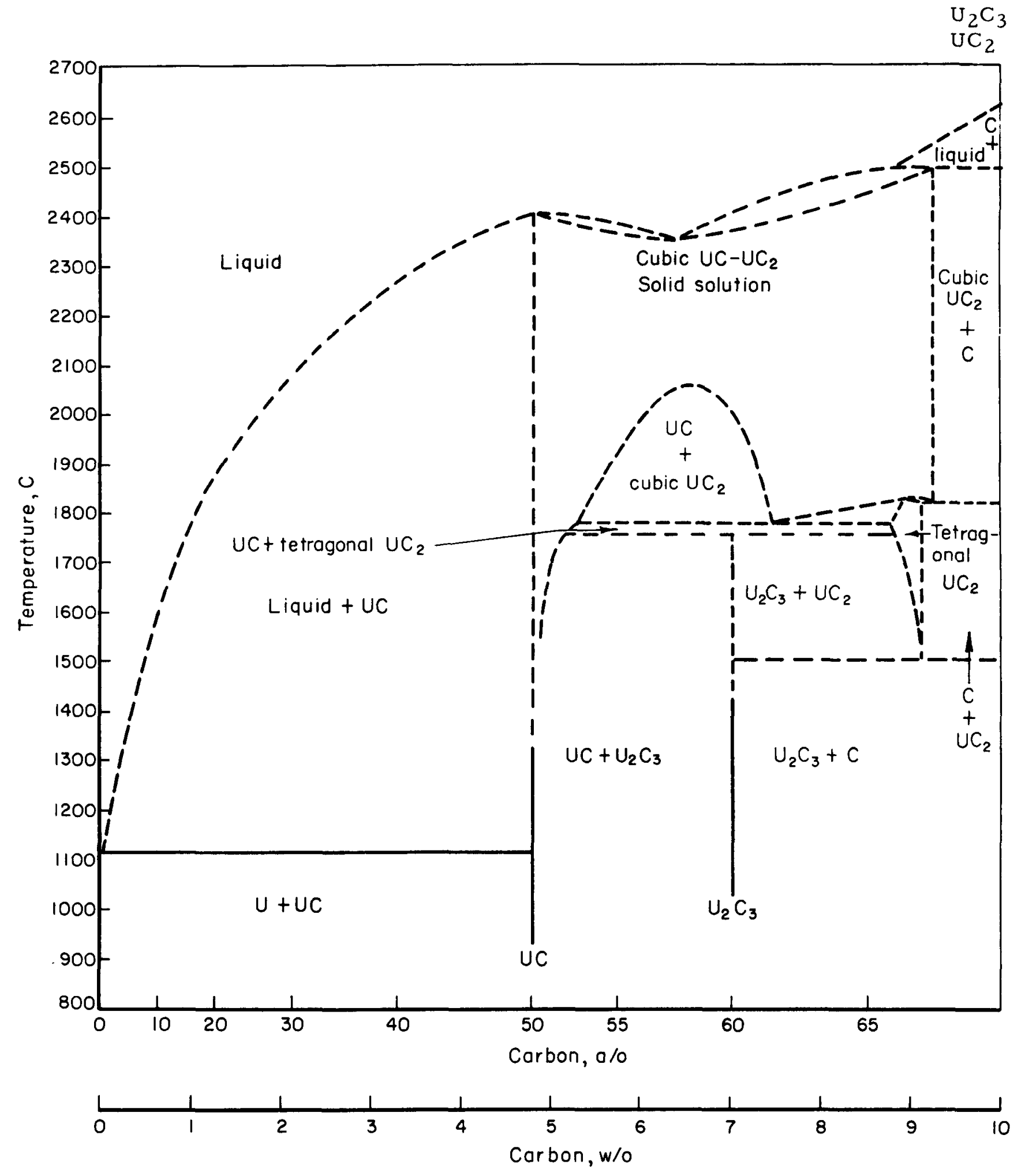

FIGURE A2. URANIUM-CARBON CONSTITUTIONAL DIAGRAM ${ }^{(1)}$ 


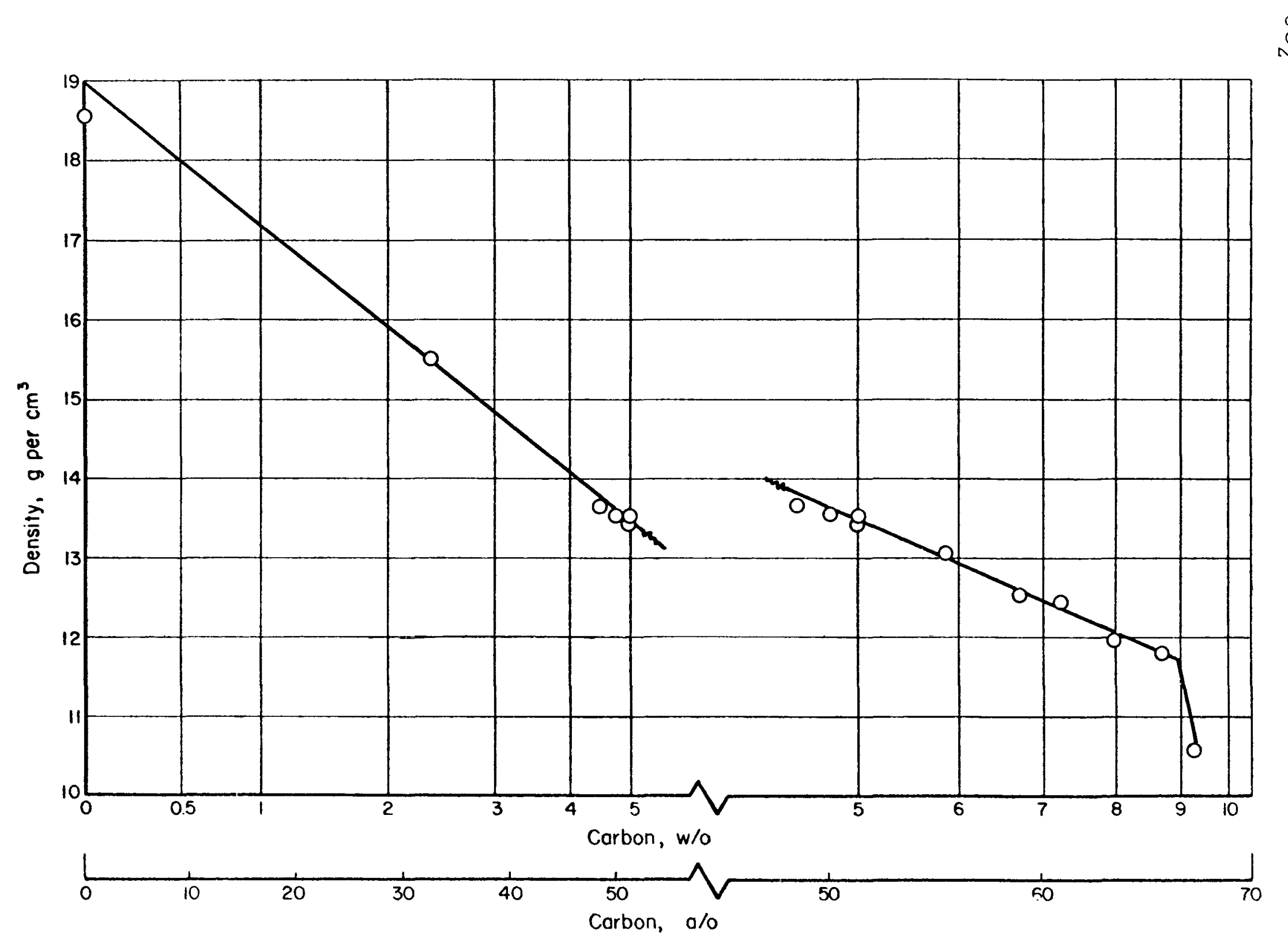

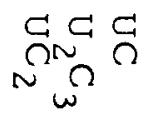

FIGURE BI. DENSITY OF AS-CAST URANIUM-CARBON ALLOYS ${ }^{(3)}$ 
7. Thermal expansion

$\begin{array}{lc}\text { As-Cast Alloys } & \begin{array}{c}\text { Coefficient } \\ \text { (a) }\end{array} \text { from } \\ \text { Uranium }-4.8 \mathrm{w} / \mathrm{o} \text { carbon } & 11.0 \\ \text { Uranium }-7.0 \mathrm{w} / 0 \text { carbon } & 12.0 \\ \text { Uranium }-9.0 \mathrm{w} / \mathrm{o} \text { carbon } & 15.8\end{array}$

(a) Calculated from dilation curves in Reference (1).

8. Recrystallization temperature range $(7,8)$

Grain growth in $\mathrm{UC}$ is very slow at $1100 \mathrm{C}$ and relatively rapid at $1700 \mathrm{C}$.

The diffusion rate of uranium in $U C$ is less than $10^{-11} \mathrm{~cm}^{2}$ per sec at $1400 \mathrm{C}$. See also C-2.

C1. Hardness (room temperature) ${ }^{(4)}$

Material

Uranium - $4.8 \mathrm{w} / \mathrm{o}$ carbon alloy, as cast, UC

Uranium - $7.0 \mathrm{w} / 0$ carbon alloy, as cast, $\mathrm{UC}+\mathrm{UC}_{2}$

Uranium - $7.0 \mathrm{w} / \mathrm{o}$ carbon alloy, annealed, $\mathrm{U}_{2} \mathrm{C}_{3}$

Uranium - $9.0 \mathrm{w} / \mathrm{o}$ carbon alloy, as cast, $\mathrm{UC}_{2}$
Typical Room Temperature Hardness, DPH, $\mathrm{kg}$ per $\mathrm{mm}^{2}$

700

750

1100

500

2. Hot hardness $(1)$

The hardness of the uranium carbides begins to decrease rapidly at about $1000 \mathrm{C}$ and falls below $100 \mathrm{~kg}$ per $\mathrm{mm}^{2}$ for all compositions between 5 and $9 \mathrm{w} / \mathrm{o}$ carbon at about $1200 \mathrm{C}$.

3. Ultimate tensile strength

No data available

4. Yield strength $(4)$

No data available; transverse rupture strengths range from $10,000 \pm$ 4,000 psi for uranium $-4.8 \mathrm{w} /$ o carbon alloy to $12,000 \pm 4,000$ psi for uranium $-7.0 \mathrm{w} / \mathrm{o}$ carbon alloy.

5. Compressive strength $(4)$

Material

Uranium $-4.8 \mathrm{w} / 0$ carbon alloy, as cast, $U C$
Uranium $-7.0 \mathrm{w} / \mathrm{o}$ carbon alloy, as cast,
$\mathrm{UC}+\mathrm{UC}_{2}$
Compressive Rupture Strength, psi

51,000

66,000 
$\mathrm{UC}_{2}$

\section{Creep strength $(9)$}

Grain-growth, hot-pressing, and hot-hardness studies show that recovery processes are active in uranium carbides at temperatures near $1100 \mathrm{C}$.

In the temperature range from 1500 to $1900 \mathrm{C}$, plastic strain rates in arccast UC follow a relation of the type:

$$
\text { Strain Rate }=k f(\sigma) \exp (-37,500 / R T) \text {, }
$$

where $k$ is a constant, $f(\sigma)$ is a functional relation of stress,

$\sigma$ is the stress (about $2000 \mathrm{psi}$ ) at 0.001 strain, $R$ is the gas constant, and $\mathrm{T}$ is the absolute temperature.

7. Young's modulus

\begin{tabular}{|c|c|c|c|}
\hline Material & $\begin{array}{c}\text { Temperature, } \\
\mathrm{C} \\
\end{array}$ & $\begin{array}{r}\text { Young's } \\
\text { Modulus, } \\
10^{6} \mathrm{psi} \\
\end{array}$ & Reference \\
\hline Uranium $-4.8 \mathrm{w} / \mathrm{o}$ carbon alloy & 20 & 29.5 & (4) \\
\hline Uranium $-7.0 \mathrm{w} / \mathrm{o}$ carbon alloy & 20 & 29.0 & (4) \\
\hline Uranium - $5.0 \mathrm{w} / 0$ carbon alloy & 20 & 29.6 & $(10)$ \\
\hline Uranium $-5.0 \mathrm{w} / \mathrm{o}$ carbon alloy & 500 & 28.8 & (10) \\
\hline Uranium $-5.0 \mathrm{w} / \mathrm{o}$ carbon alloy & 1000 & 27.2 & (10) \\
\hline Uranium $-5.0 \mathrm{w} / 0$ carbon alloy & 1500 & 20.7 & (10) \\
\hline Uranium $-5.0 \mathrm{w} / \mathrm{o}$ carbon alloy & 1700 & 14.8 & (10) \\
\hline
\end{tabular}

\section{Shear modulus}

No data available

\section{Bulk modulus}

No data available

10. Poisson's ratio

No data available

\section{Elongation}

No data available

\section{D1. Specific heat (11)}

The specific heat of a uranium $-4.8 \mathrm{w} / \mathrm{o}$ carbon alloy sintered to a density of $10.2 \mathrm{~g}$ per $\mathrm{cm}^{3}$ (75 per cent of theoretical) was found to be $0.048 \mathrm{cal} /$ $(\mathrm{g})(\mathrm{C})$ at $125 \mathrm{C}$ and $0.053 \mathrm{cal} /(\mathrm{g})(\mathrm{C})$ at $250 \mathrm{C}$.

\section{Thermal conductivity (2)}

The the rmal conductivity of UC (uranium $-4.8 \mathrm{w} / \mathrm{o}$ carbon alloy) is $0.055 \mathrm{cal} /(\mathrm{sec})(\mathrm{cm})(\mathrm{C})$ from 200 to $1000 \mathrm{C}$. 
E1. Electrical resistivity $(1,3,4)$

The resistivity at room temperature ${ }^{(3)}$ of as-cast uranium carbon alloys is shown in Figure El. The resistivity of a uranium -7 w/o carbon alloy transformed to $\mathrm{U}_{2} \mathrm{C}_{3}$ by heat treatment $(4)$ is about 210 microhm-cm at room temperature.

The resistivity of three different uranium carbon alloys as a function of temperature $(1)$ is shown in Figure E2.

\section{F1. Reactions with coolants}

a. Steam $(12,13,14)$

Uranium carbides react with steam, water, and water vapor at room temperature and above to form hydrogen, hydrocarbons, and hydrated uranium oxides. The rate is significant at room temperature and becomes catastrophic at about $100 \mathrm{C}$.

b. Helium

Uranium carbides are decarburized or oxidized depending upon the partial pressure of the oxygen imposed on the system at temperatures of about $1000 \mathrm{C}$ or above as an impurity in helium.

c. Carbon dioxide(15)

The rate of oxidation of uranium monocarbide is very rapid in carbon dioxide at $500 \mathrm{C}$ and above.

d. Nitrogen $(2)$

Uranium monocarbide dissolves nitrogen at high temperatures, forming the solid solution, $U(C, N)$, and the higher carbides and nitrides found in the ternary uranium-carbon-nitrogen system.

e. Hydrogen (16)

Hydrogen reacts with uranium dicarbide to produce uranium monocarbide and methane at $700 \mathrm{C}$.

f. Liquid metals $(17,18)$

Uranium carbides are oxidized by the oxygen normally present as an impurity in sodium and $\mathrm{NaK}$ at temperatures of $600 \mathrm{C}$ and above.

g. $\operatorname{Air}(19)$

Bulk uranium carbide begins to oxidize in oxygen at about $300 \mathrm{C}$. An initial rapid reaction is followed by a slower reaction. Apparently the first oxide to form is adherent and somewhat protective.

\section{Reactions with claddings or structural materials}

The reactions of uranium carbides with solids are characterized by a temperature range below which no perceptible reaction occurs and above which reaction occurs at a catastrophic rate. The approximate location of this temperature range is indicated by the remarks noted in Table F2. 


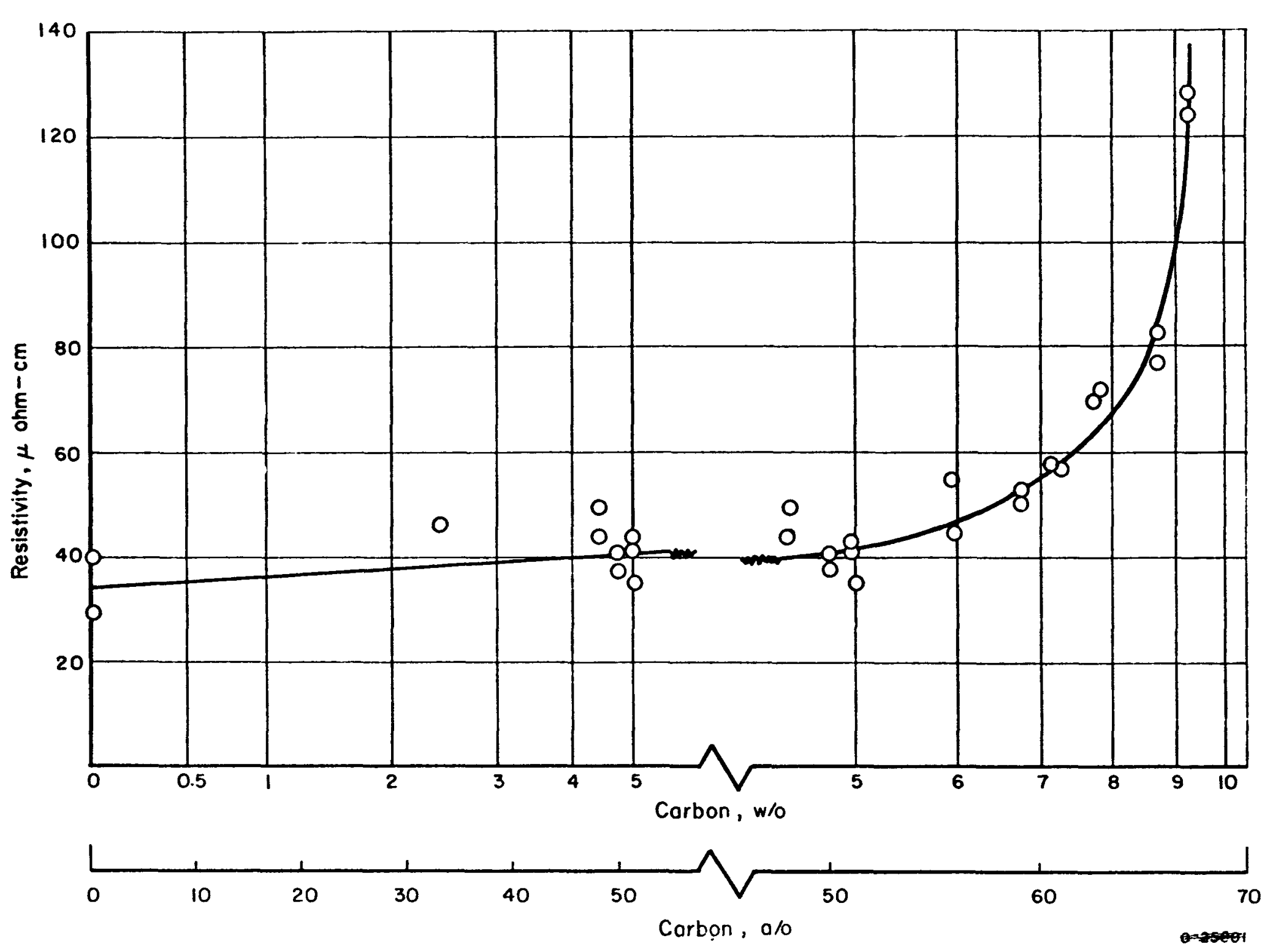

$\Omega_{\Omega}^{C} \stackrel{\Omega}{\Omega}$

FIGURE EI. RESISTIVITY OF AS-CAST URAIIUM-CARBON ALIOYS ${ }^{(3)}$

AEA-43214 


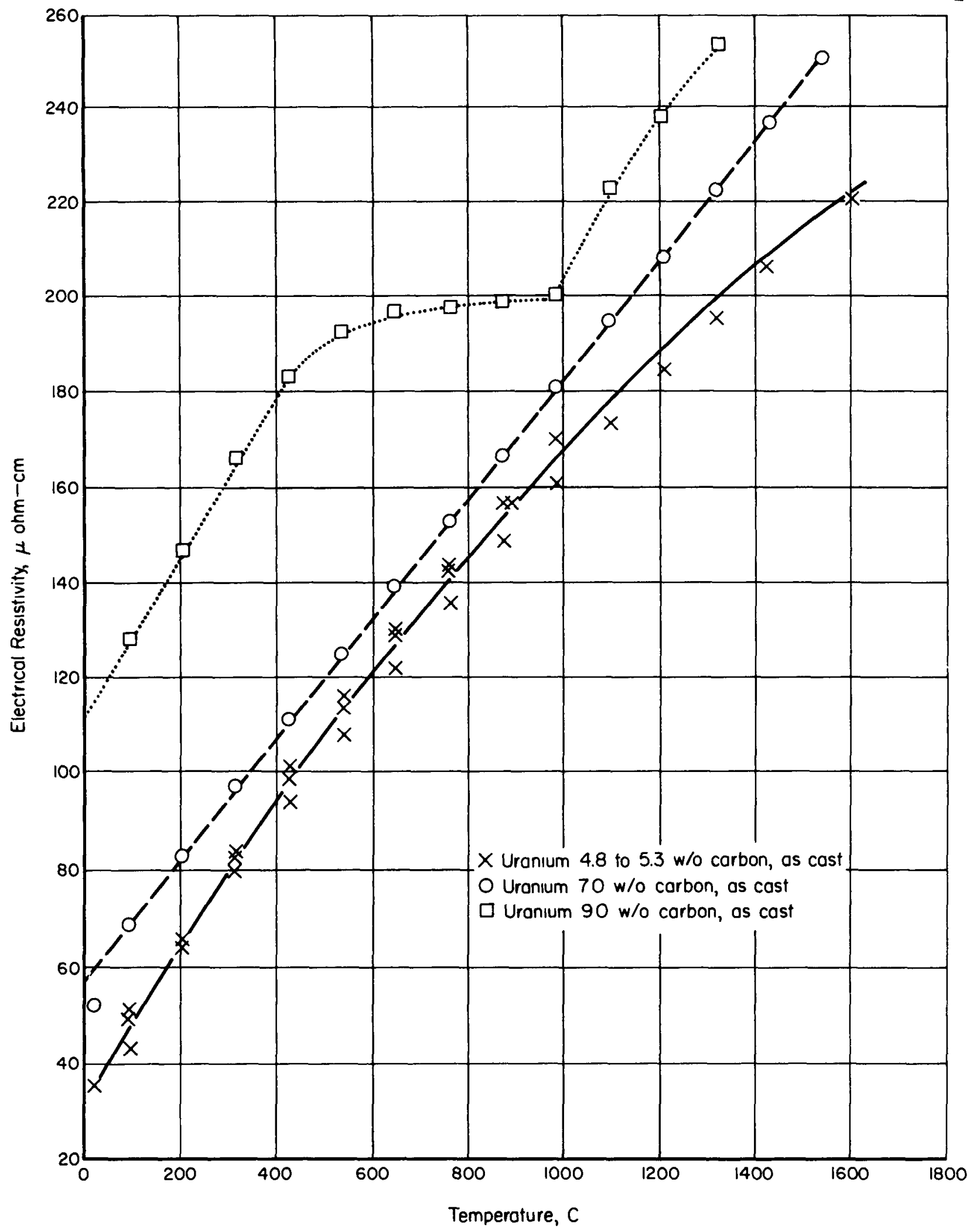

FIGURE E2. EFFECT OF TEMPERATURE ON THE ELECTRICAL RESISTIVITY OF URANIUM-CARBON ALLOYS ${ }^{(1)}$ 
TABLE F2. COMPATIBILITY OF URANIUM CARBIDES WITH SOLIDS

\begin{tabular}{|c|c|c|}
\hline $\begin{array}{c}\text { Solid } \\
\text { Material } \\
\end{array}$ & Remarks & Reference \\
\hline Aluminum & Slight reaction at $600 \mathrm{C}$ and above & $(4,20)$ \\
\hline Beryllium & Reacts to form $\mathrm{UBe}_{13}$ at $700 \mathrm{C}$ and above & $(21)$ \\
\hline Copper & No reaction at $1000 \mathrm{C}$ & (4) \\
\hline Graphite & Slight reaction at $1600 \mathrm{C}$ & (8) \\
\hline Inconel & Slight reaction at $800 \mathrm{C}$ & (4) \\
\hline Inconel $\mathrm{X}$ & Formed liquid eutectic at $82 \mathrm{C}, \mathrm{C}$ & $(22)$ \\
\hline Magnesium & No reaction at $600 \mathrm{C}$ & $(4)$ \\
\hline Molybdenum & Slight reaction at $1200 \mathrm{C}$ & $(4,23)$ \\
\hline Nickel & Rapid reaction at $1000 \mathrm{C}$ (see Inconel $\mathrm{X}$ ) & $(11)$ \\
\hline Nichrome $\mathrm{V}$ & Melted at $1100 \mathrm{C}$ (see Inconel $\mathrm{X}$ ) & (23) \\
\hline Niobium & Slight reaction at $1100 \mathrm{C}$ & (24) \\
\hline Niobium -40 a/o titanium & Formed a liquid phase at $1200 \mathrm{C}$ & (23) \\
\hline Silicon & Reacts to form USi 3 at $1000 \mathrm{C}$ & (11) \\
\hline Mild steel & Slight reaction at $1000 \mathrm{C}$ & (4) \\
\hline Type 304 stainless & No reaction with stoichiometric UC to $870 \mathrm{C}$ & $(25)$ \\
\hline Type 304 stainless & $\begin{array}{l}\text { Slight carburization of stainless by } \mathrm{U}_{2} \mathrm{C}_{3} \text { and } \\
\mathrm{UC}_{2} \text { at } 550 \mathrm{C}\end{array}$ & $(25)$ \\
\hline Tantalum & Rapid reaction at $1800 \mathrm{C}$ & $(26)$ \\
\hline Titanium & Slight reaction at $1100 \mathrm{C}$ & (27) \\
\hline Tungsten & Rapid reaction at $1800 \mathrm{C}$ & $(26)$ \\
\hline Zirconium & Slight reaction at $800 \mathrm{C}$ & $(4)$ \\
\hline Zircaloy -2 & Slight reaction at $820 \mathrm{C}$ & $(22)$ \\
\hline
\end{tabular}

G1. Dimensional stability during irradiation

As shown in Table G2, the dimensional stability of uranium carbides at moderate temperatures is excellent during irradiation.

2. Fission-gas-release data $(1,17,28)$

At temperatures up to $800 \mathrm{C}$, the fission gas released by bulk uranium carbide may be attributed entirely to fission recoils. See Table G2.

3. Swelling-temperature data

The swelling temperature of uranium carbides has not been located exactly, but appears to be over $1000 \mathrm{C}$ [See Reference (29), Table G2]. See also C6.

\section{Unusual nuclear properties}

No unusual nuclear properties of the uranium carbides have been observed.

5. Property changes as a result of irradiation

Increases in resistivity $(1,30)$ and in lattice strain( $(1)$ have been observed in uranium monocarbide. An increase in resistivity of 2.5 per cent was observed at a flux of $6 \times 10^{17}$ thermal nvt. An increase in resistivity of over 150 per cent was observed at a burnup of $1.3 \times 10^{18}$ fissions per $\mathrm{cm}^{3}$. 
TABLE G2. IRRADIATION DATA ON URANIUM CARBIDES

\begin{tabular}{|c|c|c|c|c|c|c|c|c|}
\hline \multicolumn{2}{|c|}{ Material } & \multirow[b]{2}{*}{$\begin{array}{c}\text { Central Core } \\
\text { Temperature, } \\
\text { C }\end{array}$} & \multirow[b]{2}{*}{$\begin{array}{l}\text { Average Heat- } \\
\text { Generation Rate, } \\
10^{3} \mathrm{Btu} /\left(\mathrm{ft}^{2}\right)(\mathrm{hr})\end{array}$} & \multirow{2}{*}{$\begin{array}{c}\text { Surface } \\
\text { Temperatures } \\
\text { During } \\
\text { Irradiation, } \\
\text { C }\end{array}$} & \multirow[b]{2}{*}{$\begin{array}{c}\text { Approximate } \\
\text { Burnup, } \\
\text { fissions per } \mathrm{cm}^{3}\end{array}$} & \multirow[b]{2}{*}{$\begin{array}{l}\text { Density } \\
\text { Change, } \\
\text { per cent }\end{array}$} & \multirow[b]{2}{*}{$\begin{array}{l}\text { Fission-Gas- } \\
\text { Release } \\
\text { Fraction (a) }^{\text {(a) }}\end{array}$} & \multirow[b]{2}{*}{ Reference } \\
\hline $\begin{array}{c}\text { Carbon Content } \\
\text { (Balance Uranıum), } \\
\text { w/o }\end{array}$ & $\begin{array}{c}\text { Fabrication } \\
\text { Condition }\end{array}$ & & & & & & & \\
\hline 5.2 & As cast & $590-870$ & 680 & $340-480$ & $5 \times 10^{19}$ & 0.8 & - & (17) \\
\hline 5.2 & As cast & $370-590$ & 850 & $270-350$ & $6.5 \times 10^{19}$ & 2.5 & $4 \times 10^{-4}$ & (17) \\
\hline 5.3 & As cast & $490-1000$ & 880 & $330-580$ & $2 \times 10^{20}$ & 2.0 & - & (17) \\
\hline 5.1 & As cast & $380-800$ & 940 & $270-480$ & $3 \times 10^{20}$ & 2.5 & $5 \times 10^{-4}$ & (17) \\
\hline 5.0 & As cast & $580-640$ & 700 & $330-410$ & $4.5 \times 10^{20}$ & 1.8 & -- & $(28)$ \\
\hline 5.2 & As cast & $530-680$ & - & $300-400$ & $6.5 \times 10^{20}$ & 3.4 & - & $(28)$ \\
\hline 5.3 & As cast & $430-560$ & 670 & $240-310$ & $9 \times 10^{20}$ & 4.4 & -- & $(28)$ \\
\hline 5.0 & Annealed & -- & - & $680-810$ & $2.5 \times 10^{20}$ & 0.6 & $3 \times 10^{-3}$ & (1) \\
\hline 6.7 & Annealed & -- & - & $600-740$ & $2 \times 10^{20}$ & 1.3 & -- & (1) \\
\hline 4.8 & As cast & $930-1300$ & -- & Over 1000 & $\begin{array}{l}0.5 \text { to } \\
\quad 2 \times 10^{20}\end{array}$ & Over 10 & $0.05-0.30$ & $(29,31)$ \\
\hline
\end{tabular}

(a) Amount released/amount produced. 
(1) Rough, F. A., and Chubb, W., "Progress on the Development of Uranium Carbide-Type Fuels", BMI-1554 (November 17, 1961).

(2) Rough, F. A., and Chubb, W., "An Evaluation of Data on Nuclear Carbides", BMI-1441 (May 31, 1960).

(3) Rough, F. A., and Chubb, W., "Progress on the Development of Uranium Carbide-Type Fuels", BMI-1370 (August 21, 1959).

(4) Rough, F. A., and Chubb, W., "Progress on the Development of Uranium Carbide-Type Fuels", BMI-1 488 (December 27, 1960).

(5) Leitnaker, J. M., and Witteman, W. G., "The Dissociation Pressure of Uranium Dicarbide", TID-13629 (September, 1961).

(6) Fujishiro, S., "The Dissociation Pressure of $\mathrm{UC}_{2}$...", Nippon Genshiryoku Gakkaishi, Vol. 3, pp 913-917 (December, 1961).

(7) Accary, A., and Lucas, R., "The Effect of Heat Treatment on Uranium Monocarbide and U-UC Cermets", Rev. met., 58, 383-387 (May, 1961).

(8) Chubb, W., Townley, C. W., and Getz, R. W., "Diffusion Coefficients of Uranium and Carbon in Uranium Monocarbide", BMI-1551 (November 6, 1961).

(9) Chang, R., "The Flow and Recovery of Uranium Monocarbide ...", J. Appl. Phys., 33, 858-863 (March, 1962).

(10) "Annual Technical Progress Report, Atomics International", NAA-SR-5350 (August, 1960, p VII-26.

(11) Boettcher, A., and Schneider, G., "Some Properties of Uranium Monocarbide", Proceedings of the Second United Nations International Conference on The Peaceful Uses of Atomic Energy, Geneva (1958), Vo1. 6, pp 561-563.

(12) Litz, L. M., "Uranium Carbides, Their Preparation, Structure, and Hydrolysis", The Ohio State University, Ph. D. Thesis (1948), USAEC Document No. NP-1453.

(13) Engle, G. B., Goedde1, W. V., and Luby, C. S., "Reaction-Rate Studies of Thorium-Uranium Dicarbides in Moist Air", GA-2195 (April 20, 1961).

(14) Blanco, R. E., "Quarterly Progress Report for Chemical Development Section B, April-June, 1961", ORNL-TM-1 (November 15, 1961). 
(15) Antill, J. E., Peakall, K. A., Crick, N. , and Smart, E., "Compatibility of $\mathrm{UO}_{2}$, UC, and $\mathrm{U}$ with $\mathrm{CO}_{2}$ ", AERE-M/M-168 (1957).

(16) Silverman, L., "The High Temperature Chemical Reactivities of the Uranium Carbides", NAA-SR-memo-4269 (August, 1959).

(17) Rough, F. A., Hare, A. W. , Price, R. B. , and Alfant, S., "Ir radiation of Uranium Monocarbide", Nuclear Sci. Eng. , 7, 1i1-121 (February, 1960).

(18) Gordon, E., "Quarterly Progress Report, Fuel Cycle Development Program, Oct. to Dec., 1961", UNC-3001 (February 1, 1962).

(19) Murbach, E. M., "The Oxidation of Uranium Carbide", NAA-SRmemo-5494 (July, 1960).

(20) Thurber, W. C., and Beaver, R. J., "Dispersions of Uranium Carbides in Aluminum Plate-Type Research Reactor Fuel Elements", J. Nuclear Mat., 1, 226-232 (October, 1959).

(21) "Metallurgy Division Annual Progress Report", ORNL-3160 (August 17, 1961).

(22) Sheridan, W., Strasser, A., Anderson, J., and Taylor, K. , "Carbide Fuel Development Phase Report", NDA-2162-5 (Sept. 30, 1961).

(23) Sheinhartz, I. , "Dispersion Type Materials for Fuel Elements, Part II, Uranium Carbide and Uranium Sulfide Dispersion Materials", SCNC-273 (March, 1959).

(24) Finley, J. J., Korchynsky, M., and Sarian, S. , "Columbium Alloy Clad Uranium Carbide Fuel Element", ORO-366 (September 1, 1960).

(25) "Annual Technical Progress, Fiscal Year 1961", NAA-SR-6370 (August 15, 1961).

(26) Carpenter, F. D., "Investigations of Carbides as Cathodes for Thermionic Space Reactors", GA-2670 (December, 1961).

(27) Nichols, R. W. , "Ceramic Fuels - Properties and Technology", Nuclear Eng., 3, 327-333 (August, 1958).

(28) Hare, A. W., and Rough, F. A., "The Effect of High-Burnup Irradiation on Massive Uranium Carbide", BMI-1491 (January 6, 1961).

(29) "Gas-Cooled Reactor Program Progress Report", ORNL-3166 (August 28, 1961), pp 136-148. 
(30) Griffiths, L. B., "The Effect of Irradiation and Post Irradiation Annealing on The Electrical Resistivity of Uranium Monocarbide", J. Nuclear Mat., 4, 336 (1961).

(31) Manly, W. D. , "Gas-Cooled Reactor Program Progress Report", ORNL-3302 (July 16, 1961), pp 265-266. 


\section{URANIUM MONONITRIDE}

Compiled by E. O. Speidel

\section{A1. Chemical composition}

UN, $5.56 \mathrm{w} / \mathrm{o}$ nitrogen, $94.44 \mathrm{w} / \mathrm{o}$ uranium

2. Phase diagram $(1)$

No diagram has been constructed for the uranium-nitrogen system. Three compounds, $\mathrm{UN}, \mathrm{U}_{2} \mathrm{~N}_{3}$, and $\mathrm{UN}_{2}$, are known to exist. The system is twophase between the mononitride, $U N$, and the sesquinitride, $U_{2} N_{3}$. The solubility of nitrogen in uranium is limited. The solubility of uranium in the mononitride, UN, is also limited.

The sesquinitride, $\mathrm{U}_{2} \mathrm{~N}_{3}$, is stable only to $1300 \mathrm{C}$, where it decomposes to form UN plus nitrogen at low pressures.

3. Effect of impurities (2)

No data available; variations in the lattice constant of UN have been attributed to the presence of carbon or oxygen instead of solubility of nitrogen in UN.

B1. Density (room temperature) $)^{(2)}$

$14.32 \mathrm{~g}$ per $\mathrm{cm}^{3}(\mathrm{X}-\mathrm{ray})$

2. Density versus temperoture

No data available

3. Uranium content

$13.5 \mathrm{~g}$ per $\mathrm{cm}^{3}$

4. Liquidus temperature

No data available; see B5.

5. Solidus temperature ${ }^{(3)}$

The observed melting temperature of five samples varied from 2575 to

$2710 \mathrm{C}$ under an atmosphere of $\mathrm{NH}_{3}$ (UN probably decomposes since the decomposition temperature is strongly pressure dependent).

6. Vapor pressure

No data available

7. Thermal expansion (linear) $(4,5)$

Temperature, $\mathrm{C}$

$20-1200$

$20-1600$
Coefficient, $10^{-6}$ per $\mathrm{C}$

9.7

10. 1

\section{Recrystallization temperature range}

No data available; see Reference (6) for possible data. 
C1. Hardness (room temperature) $(7,8)$

$600 \pm 50 \mathrm{KHN}$

2. Hot hardness $(4)$

\begin{tabular}{cc} 
Temperature, C & DPH \\
\hline 650 & 280 \\
760 & 220 \\
870 & 160 \\
980 & 130 \\
1090 & 120
\end{tabular}

3. Ultimate tensile strength

No data available

4. Yield strength

No data available

5. Compressive strength

No data available

6. Creep strength

No data available

7. Young's modulus

$33 \times 10^{6}$ psi [extrapolated to 100 per cent density from data in

References (4) and (5)]

8. Shear modulus

$16 \times 10^{6}$ [extrapolated to 100 per cent density from data in Reference (5)]

9. Bulk modulus

$$
25 \times 10^{6}
$$

10. Poisson's ratio

0.28 [extrapolated to 100 per cent density from data in Reference (5)]

D1. Specific heat

No data available

2. Thermal conductivity $(9)$

Temperature, $\mathrm{C}$

200

300

400

500

600

700

800

$$
\begin{gathered}
\text { Thermal Conductivity }{ }^{(\mathrm{a})}, \\
\mathrm{cal} /(\mathrm{sec})(\mathrm{cm})(\mathrm{C})
\end{gathered}
$$
0.032 (b)
0.037
0.040
0.042
0.044
0.046
0.048
0.049

(a) Measured on a 97 per cent dense specimen.

(b) Extrapolated. 
E1. Electrical resistivity $(9)$

\begin{tabular}{cc} 
Temperature, C & $\begin{array}{c}\text { Resistivity } \\
\text { microhm-cm }\end{array}$ \\
\cline { 2 - 2 } 25 & 161 (b) \\
200 & 176 \\
300 & 184 \\
400 & 190 \\
500 & 196 \\
600 & 201 \\
700 & 205 \\
800 & 208
\end{tabular}

(a) Measured on a 97 per cent dense specimen.

(b) Extrapolated.

F1. Reactions with coolants

a. Steam

No data available

b. Heliurn

No data available

c. Carbon dioxide

No data available

d. Nitrogen

Will probably form higher nitrides up to $1300 \mathrm{C}$; see A2 above.

e. Hydrogen (9)

No reaction up to $800 \mathrm{C}$

f. Liquid metals

No data available

g. $\operatorname{Air}(10)$

Catastrophic above $150 \mathrm{C}$

2. Reactions with claddings or structural materials

No enginee ring data available

G1. Dimensional stability during irradiation (11)

\begin{tabular}{|c|c|c|c|c|c|}
\hline \multirow{3}{*}{$\begin{array}{l}\text { Estimated Burnup, } \\
\text { fissions per } \mathrm{cm}^{3}\end{array}$} & \multicolumn{4}{|c|}{$\begin{array}{c}\text { Estimated } \\
\text { Temperature, } F\end{array}$} & \multirow{3}{*}{$\begin{array}{c}\text { Density } \\
\text { Decrease } \\
\text { per cent }\end{array}$} \\
\hline & \multicolumn{2}{|c|}{ Surface } & \multicolumn{2}{|c|}{ Center Line } & \\
\hline & Start & End & Start & End & \\
\hline $1.2 \times 10^{21}(\mathrm{a})$ & 1070 & 400 & 2600 & 900 & $3.5^{(b)}$ \\
\hline
\end{tabular}

(a) Estimated from reactor data.

(b) Based on dimensional measurements of cladding. 
2. Fission-gas-release data

No data available

3. Swelling-temperature data

No data available

4. Unusual nuclear properties

$$
\mathrm{N}^{14}(\mathrm{n}, \mathrm{p}) \mathrm{C}^{14} \text { reaction }
$$

5. Property changes as a result of irradiation (12)

Effects of neutron radiation on crystal structure:

$$
\frac{\Delta a}{a}=1.67-1.67 \exp \left(-7 \times 10^{-18} \mathrm{n}\right)
$$

where $\frac{\Delta a}{a}$ is fractional increase in unit-cell size, and $n$ is neutron dose in $\mathrm{n}$ per $\mathrm{cm}^{2}$. Specimens used were irradiated in the BEPO reactor in a flux of about $10^{12} \mathrm{n} /\left(\mathrm{cm}^{2}\right)(\mathrm{sec})$ at ambient temperature.

\section{H. References}

(1) Rough, F. A., and Bauer, A. A. "Constitution of Uranium and Thorium Alloys", BMI-1300 (June 2, 1958)

(2) Rundle, R. E., Baenziger, N. C., Wilson, A. S., and McDonald, R. A., "The Structures of the Carbides, Nitrides and Oxides of Uranium", J. Am. Chem. Soc., 70, 99-105 (1948).

(3) Chiotti, P., "Experimental Refractory Bodies of High Melting Nitrides, Carbides, and Uranium Dioxide", J. Am. Ceram. Soc., 35, $123-130$ (1952).

(4) Keller, D. L., "Development of Uranium Mononitride", Quarterly Progress Report for July-September, 1961, to Joint U.S.-Euratom Research and Development Board, BMI-X-178 (EUR/AEC-169) (October 1, 1961).

(5) Taylor, K. M. , and McMurtry, C. H. , "Synthesis and Fabrication of Refractory Uranium Compounds, Summary Report for May, 1959 through December, 1960", ORO-400 (February, 1961).

(6) Accary, A., and Marchal, M., "Behavior of Uranium Mononitride Under Heat Treatment", Mem. Sci. Rev. Met., 59, 57-70 (January, 1962).

(7) Epstein, H. M. , and Keller, D. L., "Quarterly Progress Report to Joint U.S. - EURATOM Research and Development Board on Battelle Assistance to AEC-EURATOM Program for the Period Ending December 31, 1960", TID-11928 (EUR/AEC-75). 
(8) Epstein, H. M., and Keller, D. L., "Quarterly Progress Report to Joint U.S. - EURATOM Research and Development Board on Battelle Assistance to AEC-EURATOM Program for the Period Ending March 31, 1961", TID-12551 (EUR/AEC-76).

(9) Keller, D. L., "Quarterly Progress Report to Joint US-EURATOM Research and Development Board on Development of Uranium Mononitride for the Period Ending June 30, 1961", (EUR/AEC-77).

(10) Speidel, E., Battelle Memorial Institute, Unpublished Information.

(11) Keller, D. L., "Development of Uranium Mononitride, Quarterly Progress Report for January-March, 1962 to Joint U.S. -EURATOM Research and Development Board", EUR/AEC-348 (April 1, 1962).

(12) Adams, J., and Rogers, M. D. , "X-Ray Diffraction Studies of Fission Fragment Damage in Uranium Carbide and Nitride", J. Nuclear Energy, Pts. A \& B., Reactor Sci. Technol., 14, 51-53 (April, 1961) 


\section{URANIUM OXIDES}

Compiled by J. B. Melehan, F. A. Rough, and M. Kangilaski

\section{A1. Chemical composition}
a. Stoichiometric $\mathrm{UO}_{2}, 88.15 \mathrm{w} / \mathrm{o}$ uranium, $11.85 \mathrm{w} / \mathrm{o}$ oxygen
b. $\mathrm{U}_{4} \mathrm{O}_{9}, 86.86 \mathrm{w} / \mathrm{o}$ uranium, $13.14 \mathrm{w} / \mathrm{o}$ oxygen
c. $\mathrm{U}_{3} \mathrm{O}_{7}, 86.44 \mathrm{w} / \mathrm{o}$ uranium, $13.56 \mathrm{w} / \mathrm{o}$ oxygen
d. $\mathrm{U}_{3} \mathrm{O}_{8}, 84.80 \mathrm{w} / \mathrm{o}$ uranium, $15.20 \mathrm{w} / \mathrm{o}$ oxygen
e. $\mathrm{UO}_{3}, 83.22 \mathrm{w} / \mathrm{o}$ uranium, $16.78 \mathrm{w} / \mathrm{o}$ oxygen

2. Phase diagram (1)

See Figure A2

\section{Effect of impurities}

The principal impurity of interest is oxygen. The addition of excess oxygen results in decreased lattice parameters of $\mathrm{UO}_{2}(\mathrm{a}=5.4691 \pm 0.005 \mathrm{~A})$ until the $\mathrm{U}_{4} \mathrm{O}_{9}(\mathrm{a}=5.441 \mathrm{l} \mathrm{A})$ composition is attained. The cubic fluoride-type $\mathrm{UO}_{2}$ is modified gradually in the $\mathrm{UO}_{2}-\mathrm{U}_{4} \mathrm{O}_{9}$ phase region and is finally converted to the cubic $\mathrm{U}_{4} \mathrm{O}_{9}$ structure. The $\mathrm{U}_{3} \mathrm{O}_{7}$ structure is tetragonal with $a=5.447 \pm 0.003 \mathrm{~A}, \mathrm{c}=5.400 \pm 0.002 \mathrm{~A}$, and is only stable below $200 \mathrm{C}$ and at compositions less than $\mathrm{UO}_{2} .33 \cdot \mathrm{U}_{3} \mathrm{O}_{8}$ is orthorhombic with the lattice constants $a=6.91 \pm 0.01 \mathrm{~A}, \mathrm{~b}=11.96 \pm 0.03 \mathrm{~A}$, and $\mathrm{c}=4.15 \pm$ $0.01 \mathrm{~A}$. The $\mathrm{UO}_{3}$ exists in two modifications, alpha $\mathrm{UO}_{3}$ with a hexagonal structure $(a=3.971 \pm 0.004 \mathrm{~A}$ and $\mathrm{c}=4.168 \pm 0.008 \mathrm{~A})$ and beta $\mathrm{UO}_{3}$ with an orthorhombic structure $(a=13.01 \mathrm{~A}, \mathrm{~b}=10.92 \mathrm{~A}, \mathrm{c}=9.51 \mathrm{~A})$. There has been no systematic study of the effect of ternary, metallic, or nonmetallic additions on the composition limits.

\section{B1. Density (room temperature) ${ }^{(1-7)}$}

a. Theoretical density of stoichiometric $\mathrm{UO}_{2}$ (based on X-ray diffraction analysis) is 10.95 to $10.97 \mathrm{~g}$ per $\mathrm{cm}^{3}$.

b. Change of density with oxygen content is shown in Figure B1. (1)

\section{Density versus temperature} See B7.

3. Uranium content

$$
9.67 \mathrm{~g} \text { per } \mathrm{cm}^{3}
$$




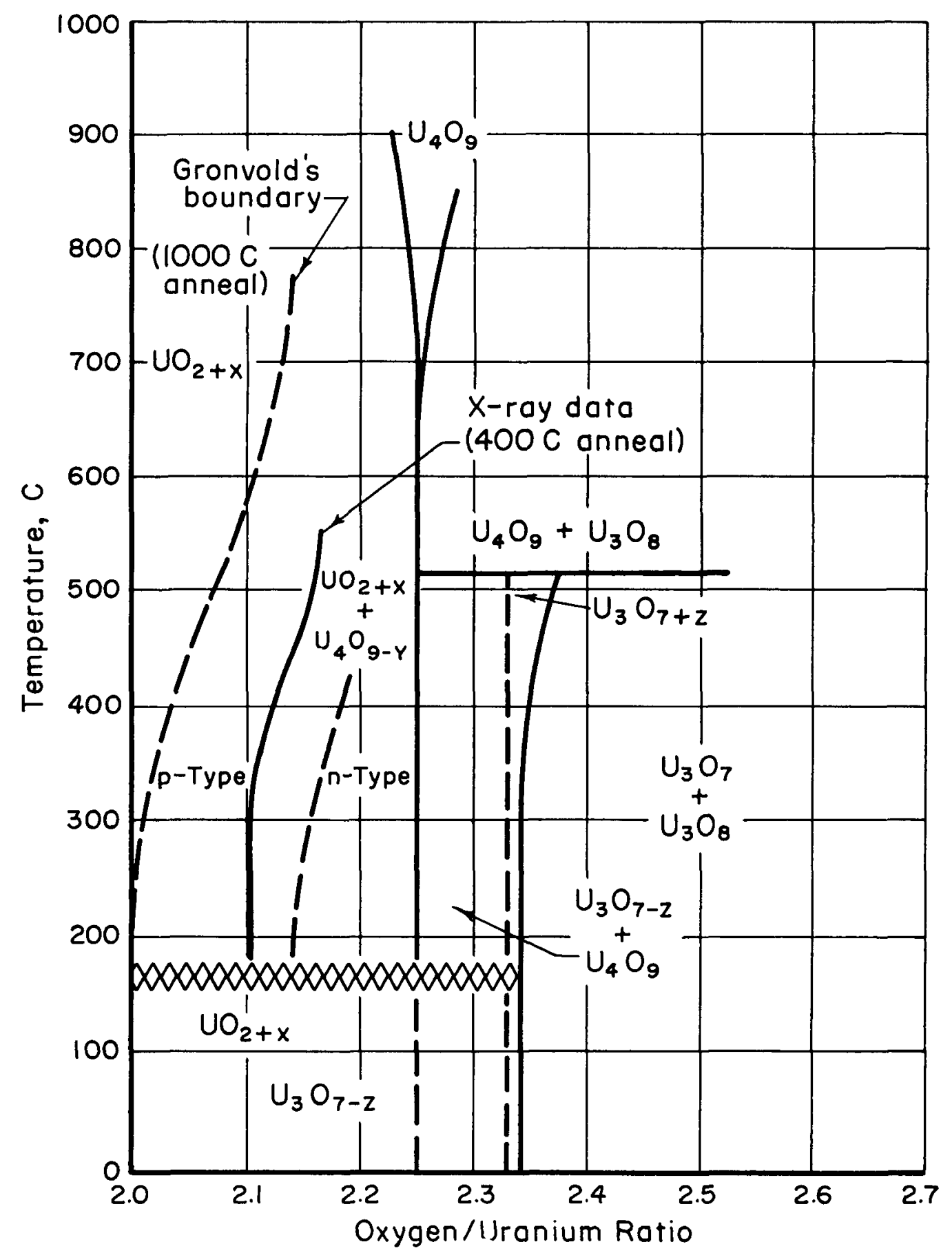

FIGURE A2. $\mathrm{UO}_{2}-\mathrm{U}_{3} \mathrm{O}_{7}$ PHASE DIAGRAM ${ }^{(1)}$ 


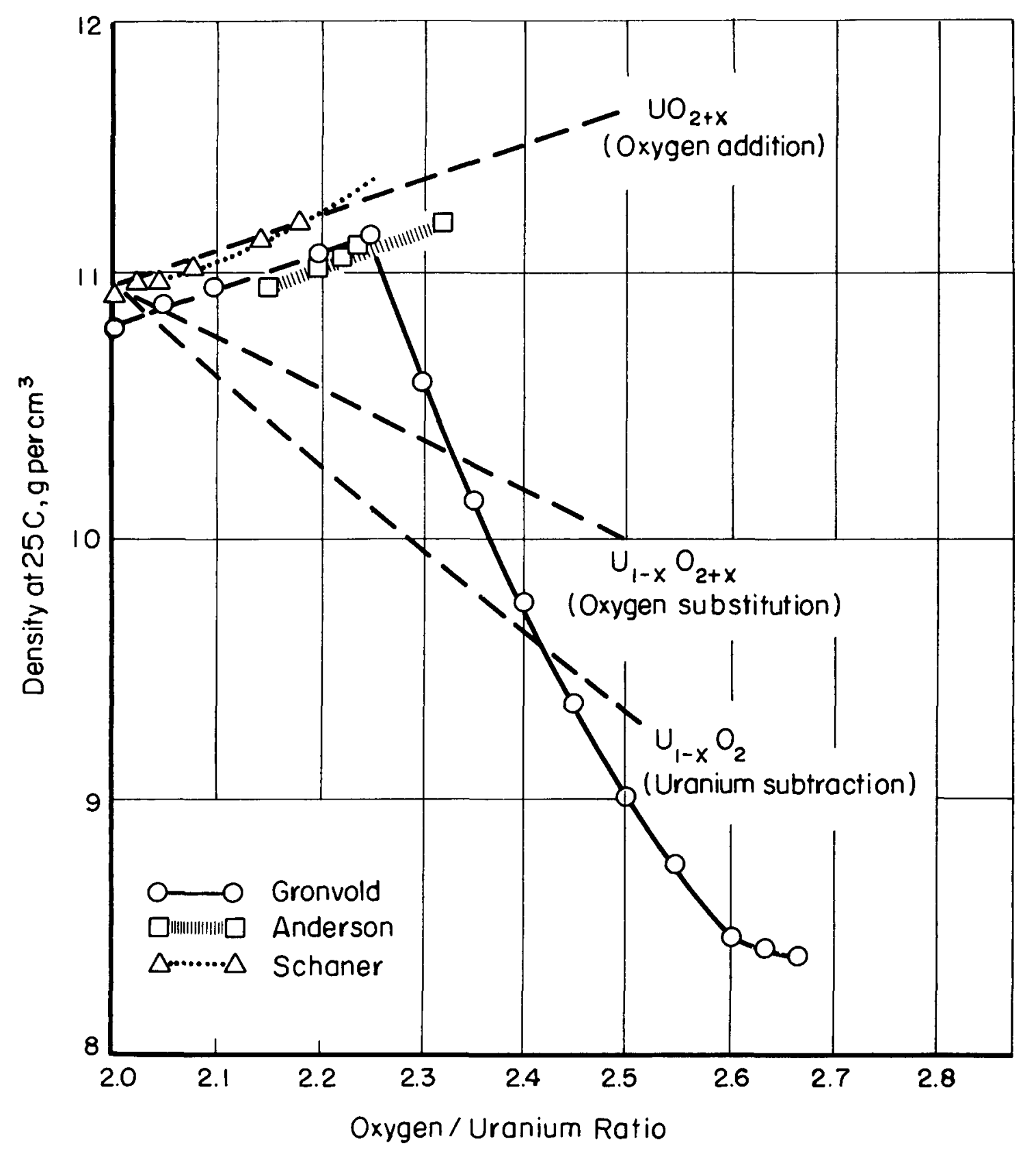

FIGURE BI. URANIUM OXIDE DENSITY AS A FUNCTION OF COMPOSITION ${ }^{(1)}$ 
4. Liquidus temperature $(8 \cdot 11)$

a. In helium atmosphere using a tungsten crucible: $2800 \mathrm{C} \pm 20 \mathrm{C}$

b. In vacuum: $2405 \mathrm{C} \pm 20 \mathrm{C}$

c. In hydrogen, argon, or helium: $2760 \pm 30 \mathrm{C}$

\section{Solidus temperature}

Same as liquidus temperature

6. Vapor pressure $(12,13)$

a. Vaporization of stoichiometric $\mathrm{UO}_{2}$

From 1600-2000 K:

$$
\log \mathrm{P}_{(\mathrm{mmHg})}=-\frac{33,115}{\mathrm{~T}}-4.026 \log \mathrm{T}+25.686
$$

Above $2000 \mathrm{~K}$ :

$$
\log \mathrm{P}_{(\mathrm{mmHg})}=13.298-\frac{3.7195 \times 10^{4}}{\mathrm{~T}} \quad \frac{3.5612 \times 10^{6}}{\mathrm{~T}^{2}} \quad \frac{2.6178 \times 109}{\mathrm{~T}^{3}} .
$$

b. Vapor pressure of $\mathrm{UO}_{3}$ from thermodynamic data for crystalline $\mathrm{UO}_{2}$ and gaseous $\mathrm{UO}_{3}$.

Below $2000 \mathrm{~K}$ :

$$
\begin{aligned}
& \log \mathrm{p}_{(\mathrm{atm})}=-\frac{13,100}{\mathrm{~T}}+4.73+1 / 2 \log \mathrm{P}_{\mathrm{O}_{2}}, \text { where } \\
& \mathrm{PO}_{2}=\text { partial pressure of oxygen over } \mathrm{UO}_{3} .
\end{aligned}
$$

7. Thermal expansion (linear) $(7,14,15)$

a. Dilatometric linear thermal expansion to the melting point of $\mathrm{UO}_{2}(93$ per cent of theoretical density): $1=1_{0}\left(1+6.0 \times 10^{-6} \mathrm{~T}+2.0 \times 10^{-9} \mathrm{~T}^{2}+1.7 \times\right.$ $10^{-12} \mathrm{~T}^{3}$ ), where $\mathrm{T}=$ temperature, $\mathrm{K}$.

b. X-ray diffraction measurements of $\mathrm{UO}_{2}$ cell size give expansion coefficients of $9.9 \times 10^{-6}$ to $10.8 \times 10^{-6}$ per $C$.

\section{Recrystallization temperature range}

No data available

9. Grain growth $(16)$

See Figure B9. 


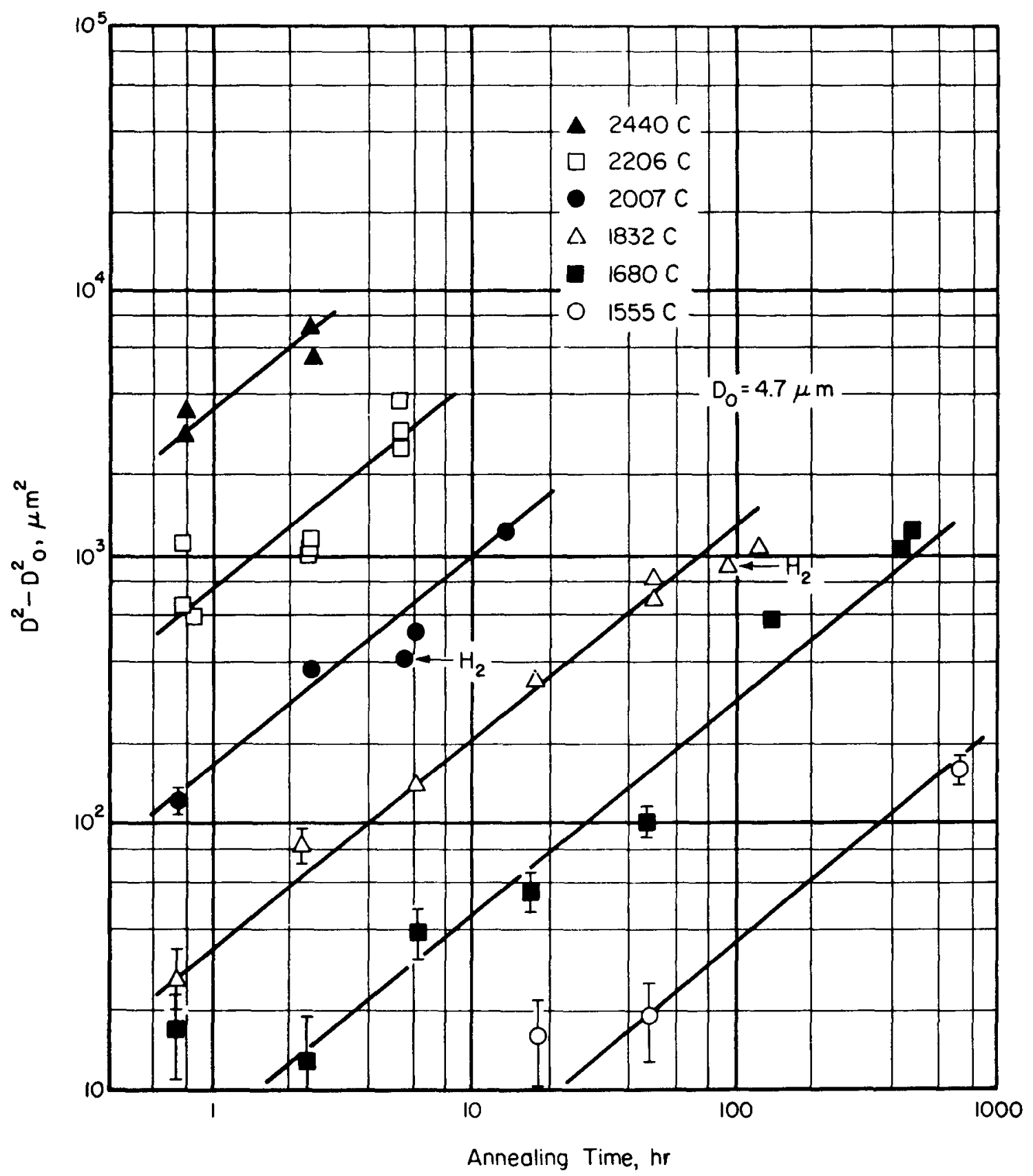

FIGURE B9 VARIATION OF GRAIN SIZE WITH ANNEALING TIME AND TEMPERATURE ${ }^{(16)}$ $D$ is the new diameter and $D_{O}$ is the old diameter.

AEA-43237 
C1. Hardness (room temperature) $(9,17)$

a. The load and crystal direction has considerable effect on the microhardness. See Figures Cla(18).

b. Effect of oxygen/uranium ratio on hardness of single-phase $\mathrm{UO}_{2+\mathrm{x}}$ is shown in Figure Clb. (1)

2. Hot hardness

No data available

3. Ultimate tensile strength $(17,19,20)$

a. Modulus of rupture is shown in Table C3.

b. Fracture strength ranges from 2300 to 5400 psi (determined indirectly from compressive strength perpendicular to the axis of specimen).

5. Compressive strength $(17)$

See Table C5.

TABLE C5. COMPRESSIVE STRENGTH OF FUSED

$\mathrm{UO}_{2}$ AT ROOM TEMPERATURE(17)

\begin{tabular}{ccc}
\hline Grain Size, $\mu$ & $\begin{array}{c}\text { Length/Diameter } \\
\text { Ratio }\end{array}$ & $\begin{array}{c}\text { Average Compressive } \\
\text { Strength, psi }\end{array}$ \\
\hline $0-5$ & $2: 1$ & 140,000 \\
$10-15$ & $2: 1$ & 70,000 \\
$15-20$ & $2: 1$ & 60,000 \\
\hline
\end{tabular}

6. Creep strength $(20)$

Three-point loading test data are presented in Figures C6a, C6b, and C6c.

7. Young's modulus $(21,22)$

a. See Table C7.

b. Effect of nonstoichiometry on Young's modulus

96 per cent dense $\mathrm{UO}_{2.16}: \mathrm{E}=18 \times 10^{6} \mathrm{psi}$

After hydrogen reduction at $1200 \mathrm{C}: \mathrm{E}=27 \times 10^{6}$.

8. Shear modulus $(21)$

See Table $\mathbf{C 7}$. 


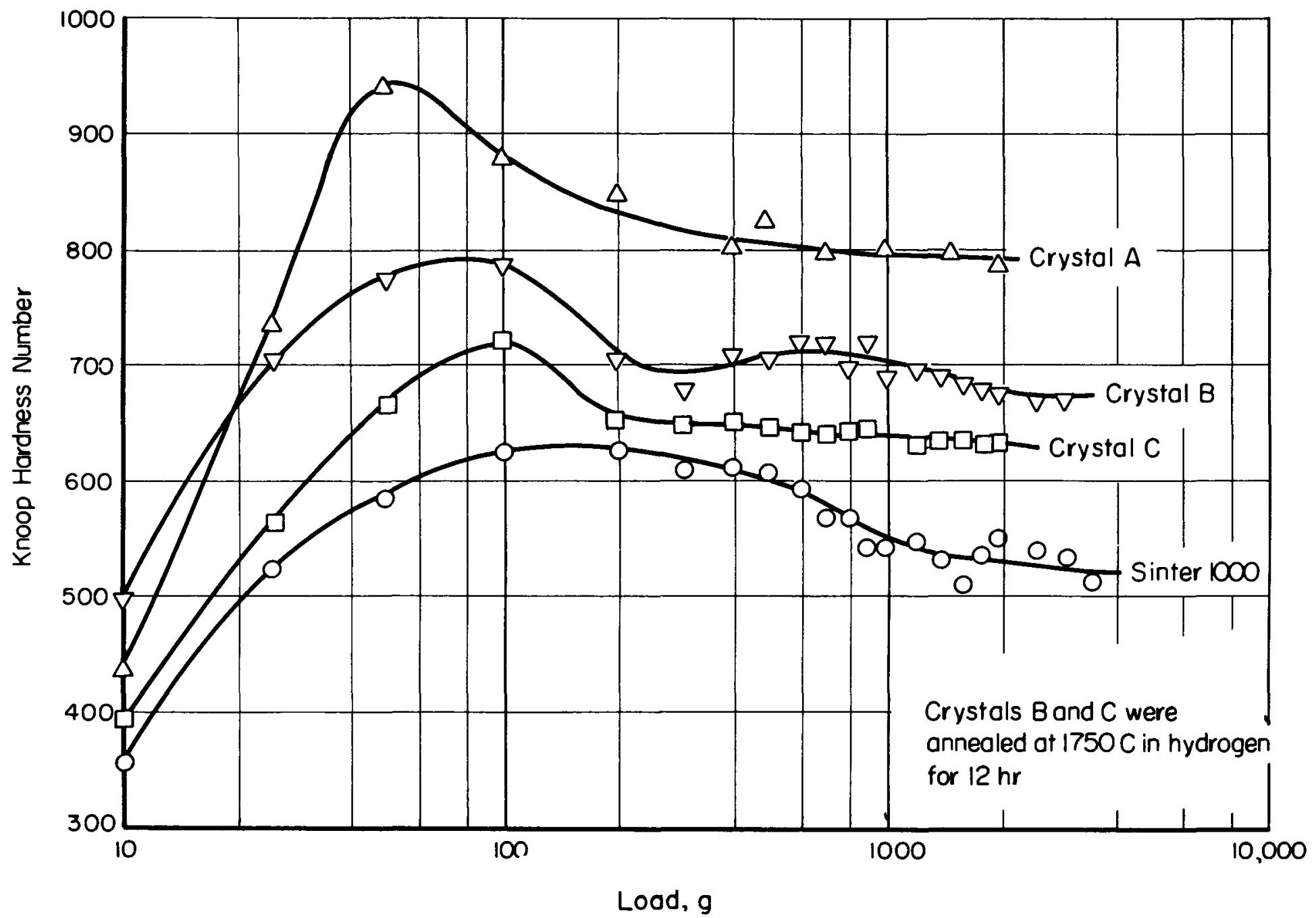

FIGURE CIQ MICROHARDNESS OF URANIUM DIOXIDE ${ }^{(18)}$ 


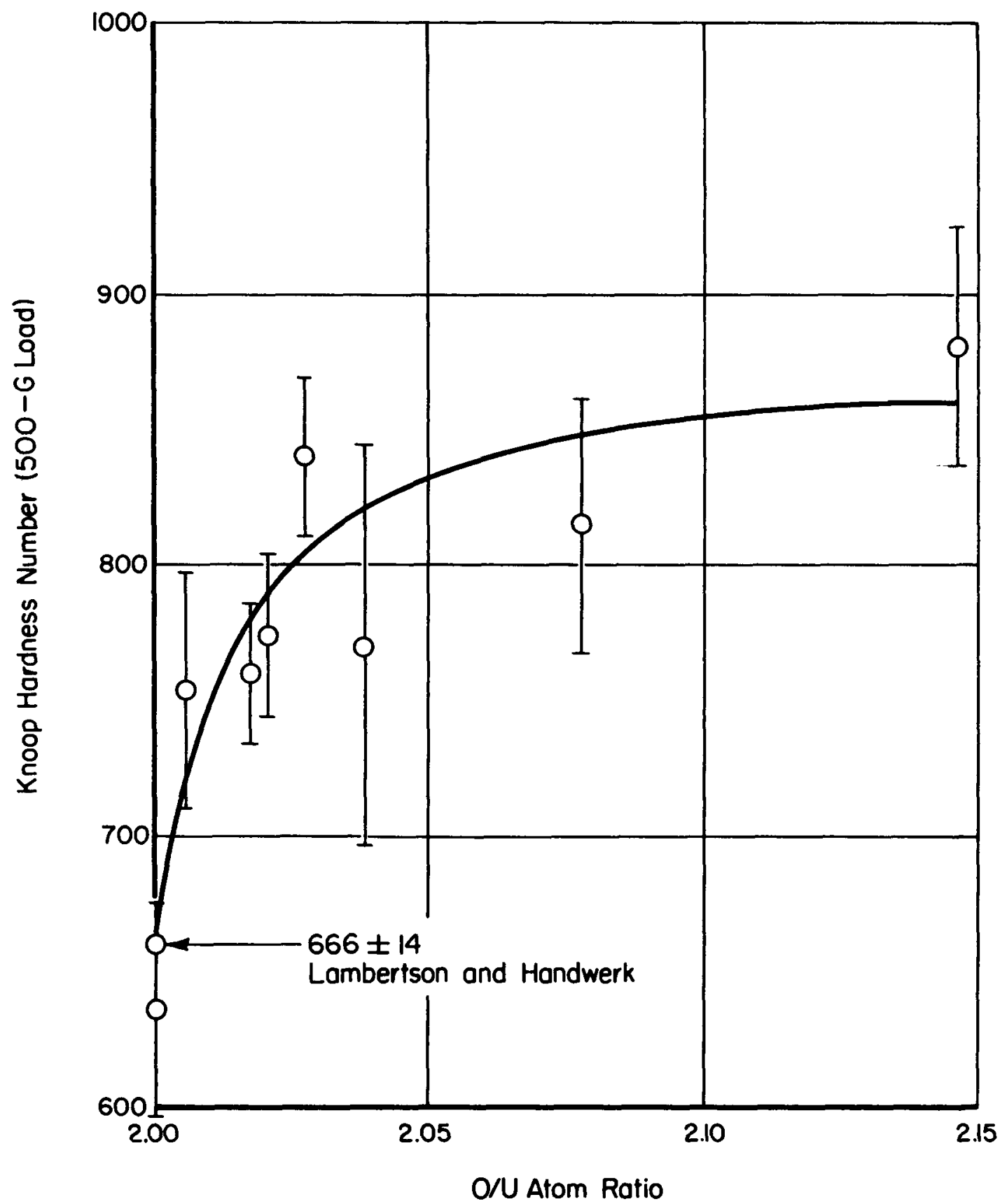

FIGURE CIb. EFFECT OF OXYGEN CONTENT ON HARDNESS OF $\mathrm{UO}_{2+x}$ SOLID SOLUTION

Samples were annealed at $900 \mathrm{C}$ for $67 \mathrm{hr}$ and quenched to room temperoture. ${ }^{(1,18)}$ 
TABLE C3. BEND STRENGTH AND BULK DENSITY OF DIFFERENT UO 2 CERAMICS $^{(1)}$

\begin{tabular}{|c|c|c|c|c|c|c|c|}
\hline \multirow[b]{3}{*}{ Startung $\mathrm{UO}_{2}$ Powder } & \multirow{2}{*}{\multicolumn{3}{|c|}{ Sintering Conditions $(a)$}} & \multicolumn{4}{|c|}{ Strength Data } \\
\hline & & & & \multirow[b]{2}{*}{$\begin{array}{l}\text { Number of } \\
\text { Specimens }\end{array}$} & \multirow{2}{*}{$\begin{array}{c}\text { Average } \\
\text { Modulus of } \\
\text { Rupture, psi }\end{array}$} & \multirow{2}{*}{$\begin{array}{c}\text { Standard } \\
\text { Deviation, } \\
\text { psi }\end{array}$} & \multirow{2}{*}{$\begin{array}{c}\text { Bulk } \\
\text { Density, } \\
\text { g per } \mathrm{cm}^{3}\end{array}$} \\
\hline & Atmosphere & $\begin{array}{l}\text { Temperature, } \\
\text { C }\end{array}$ & $\begin{array}{c}\text { Time, } \\
\text { hr }\end{array}$ & & & & \\
\hline \multicolumn{8}{|c|}{ At Room Temperature } \\
\hline Fused, 0 to $5 \mu^{(b)}$ & Argon & 2000 & $1 / 2$ & 4 & 11,990 & 2,370 & 10.10 \\
\hline Fused, 5 to $10 \mu$ & Argon & 2000 & $1 / 2$ & 4 & 9,480 & 1,180 & 9.68 \\
\hline Fused, 10 to $15 \mu$ & Argon & 2000 & $1 / 2$ & 6 & 10,270 & 1,040 & 9.14 \\
\hline Fused, 15 to $20 \mu$ & Argon & 2000 & $1 / 2$ & 4 & 8,610 & 1,380 & 8.48 \\
\hline Fused, 0 to $5 \mu$ & Helium & 2000 & $1 / 2$ & 9 & 12,920 & 1,261 & 9.89 \\
\hline Steam oxidized(c) & Helıum & 2000 & 1 & 8 & 7,340 & 560 & 8.34 \\
\hline Hydrogenated steam oxidized(c) & Helium & 2000 & 1 & 7 & 9,580 & 637 & 8.82 \\
\hline Peroxide precipitated(c) & Helium & 2000 & 1 & 6 & 12,400 & 1,610 & 10.04 \\
\hline Ammonia precipitated(c) & Helium & $1900-2000$ & 1 & 12 & 11,100 & 1,230 & 9.84 \\
\hline $\begin{array}{l}\text { Steam oxıdized }+0.75 \mathrm{w} / \mathrm{o} \mathrm{TlO}_{2} \\
\text { Hydrogenated steam oxialzed }+0.50\end{array}$ & Helium & 1900 & 1 & 7 & 12,700 & 2,180 & 9.66 \\
\hline $\mathrm{w} / \mathrm{o} \mathrm{TlO}_{2}$ & Helium & 1800 & 1 & 6 & 14,500 & 3,180 & 10.10 \\
\hline Peroxide precipitated $+0.25 \mathrm{w} / \mathrm{o} \mathrm{T} \mathrm{O}_{2}$ & Helium & 1600 & 1 & 7 & 10,400 & 2,800 & 10.39 \\
\hline $\begin{array}{l}\text { Peroxide precipitated }+0.2 \mathrm{w} / \mathrm{o} \text { alumi- } \\
\text { num stearate }\end{array}$ & Hellum & 2000 & 1 & 8 & 12,700 & 1,730 & 10.37 \\
\hline $\begin{array}{l}\text { A mmonia precipitated }+0.2 \mathrm{w} / \mathrm{o} \\
\text { aluminum stearate }\end{array}$ & Hellum & 2000 & 1 & 11 & 10,870 & 1,164 & 10.26 \\
\hline \multicolumn{8}{|c|}{ At $1000 \mathrm{C}$} \\
\hline Fused, 0 to $5 \mu$ & Argon & 2000 & $1 / 2$ & 3 & 17,980 & 900 & 10.02 \\
\hline Fused, 5 to $10 \mu$ & Argon & 2000 & $1 / 2$ & 4 & 15,790 & 1,050 & 9.56 \\
\hline Fused, 10 to $15 \mu$ & Argon & 2000 & $1 / 2$ & 6 & 12,590 & 3,170 & 9.17 \\
\hline Fused, 15 to $20 \mu$ & Argon & 2000 & $1 / 2$ & 4 & 8,280 & 1,080 & 8.48 \\
\hline Fused, 0 to $5 \mu$ & Hellum & 2000 & $1 / 2$ & 9 & 14,900 & 2,020 & 9.89 \\
\hline Steam oxidized & Helium & 2000 & 1 & 7 & 7,700 & 897 & 8.34 \\
\hline Hydrogenated steam oxidized & Helium & 2000 & 1 & 8 & 10,800 & 1,210 & 8.81 \\
\hline Peroxide precipitated & Helium & 2000 & 1 & 7 & 21,700 & 3,770 & 10.05 \\
\hline Ammonia precipitated & Helium & $1900-2000$ & 1 & 12 & 9,380 & 1,440 & 9.85 \\
\hline $\begin{array}{l}\text { Steam oxıdized }+0.75 \mathrm{w} / \mathrm{o} \mathrm{TlO} \\
\text { Hydrogenated steam oxıdızed }+0.50 \mathrm{w} /\end{array}$ & Helium & 1900 & 1 & 7 & 15,600 & 846 & 9.62 \\
\hline $\mathrm{TiO}_{2}$ & Helium & 1800 & 1 & 8 & 19,500 & 1,480 & 10.13 \\
\hline $\begin{array}{l}\text { Peroxide precipitated }+0.25 \mathrm{w} / 0 \mathrm{~T}_{10} \\
\text { Peroxide precipitated }+0.2 \mathrm{w} / \mathrm{o} \text { alum }-\end{array}$ & Helium & 1600 & 1 & 6 & 13,600 & 3,060 & 10.39 \\
\hline num stearate & Helıum & 2000 & 1 & 15 & 11,800 & 1,820 & 10.36 \\
\hline $\begin{array}{l}\text { A mmonia precipitated }+0.2 \mathrm{w} / \mathrm{o} \\
\text { aluminum stearate }\end{array}$ & Helium & 2000 & 1 & 16 & 9,380 & 1,770 & 10.30 \\
\hline
\end{tabular}

(a) Forming. Preformed in a steel mold and then hydrostatically repressed at 45,000 psi, no binder used. Sintering Tungsten setter plates, inductively heated, graphite susceptor furnace.

Finishing specimens ground and lapped to $1 / 8 \times 1 / 4 \times 1-1 / 4 \mathrm{in}$.

(b) Norton Company electnc-arc fused $\mathrm{UO}_{2}$.

(c) Prepared by ORNL. 


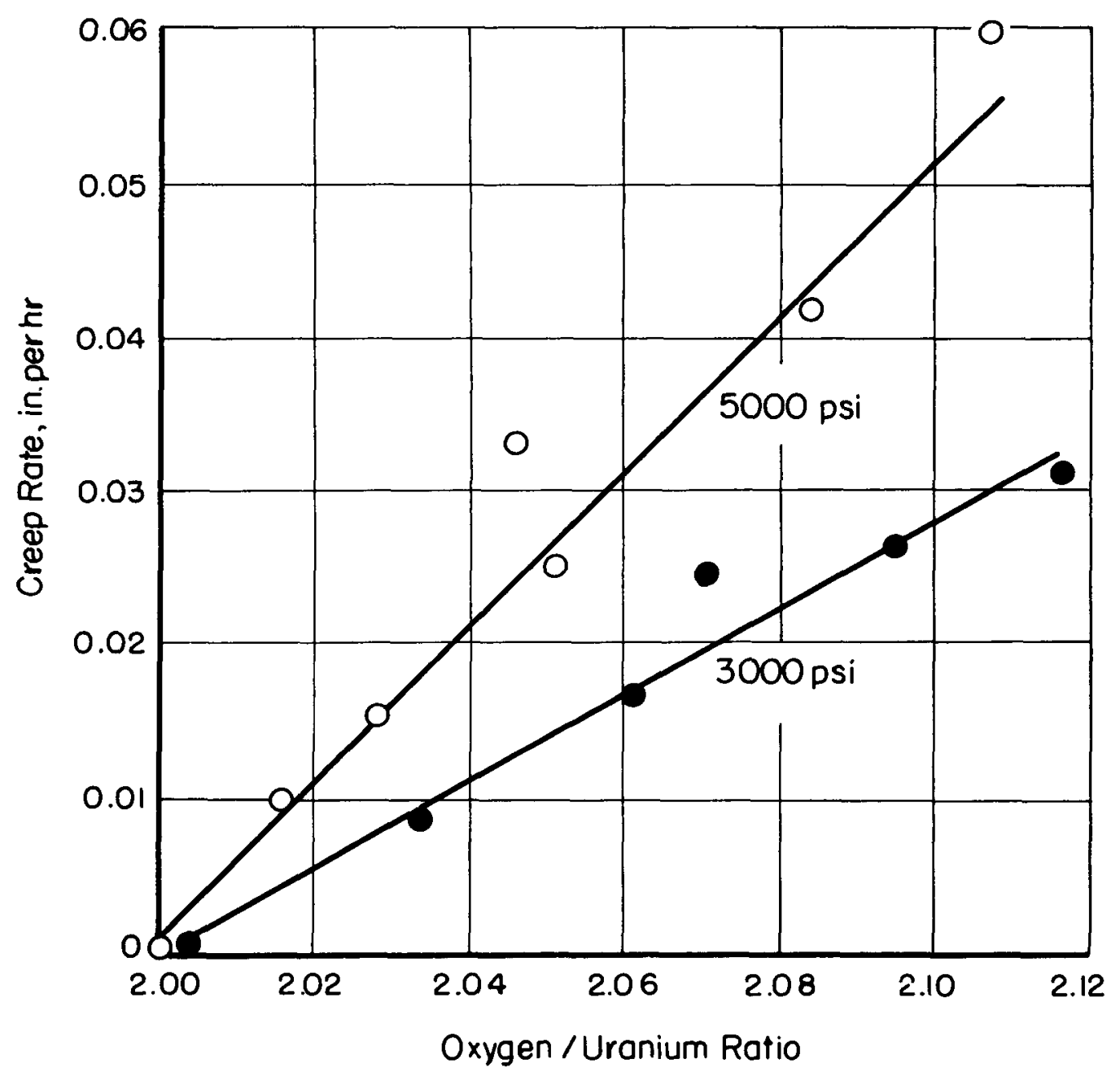

FIGURE C6O. DEPENDENCE OF CREEP RATES ON EXCESS OXYGEN AT I3OOC FOR MAXIMUM (INITIAL) STRESSES OF 5000 AND 3000 PSI ${ }^{\text {(20) }}$ 


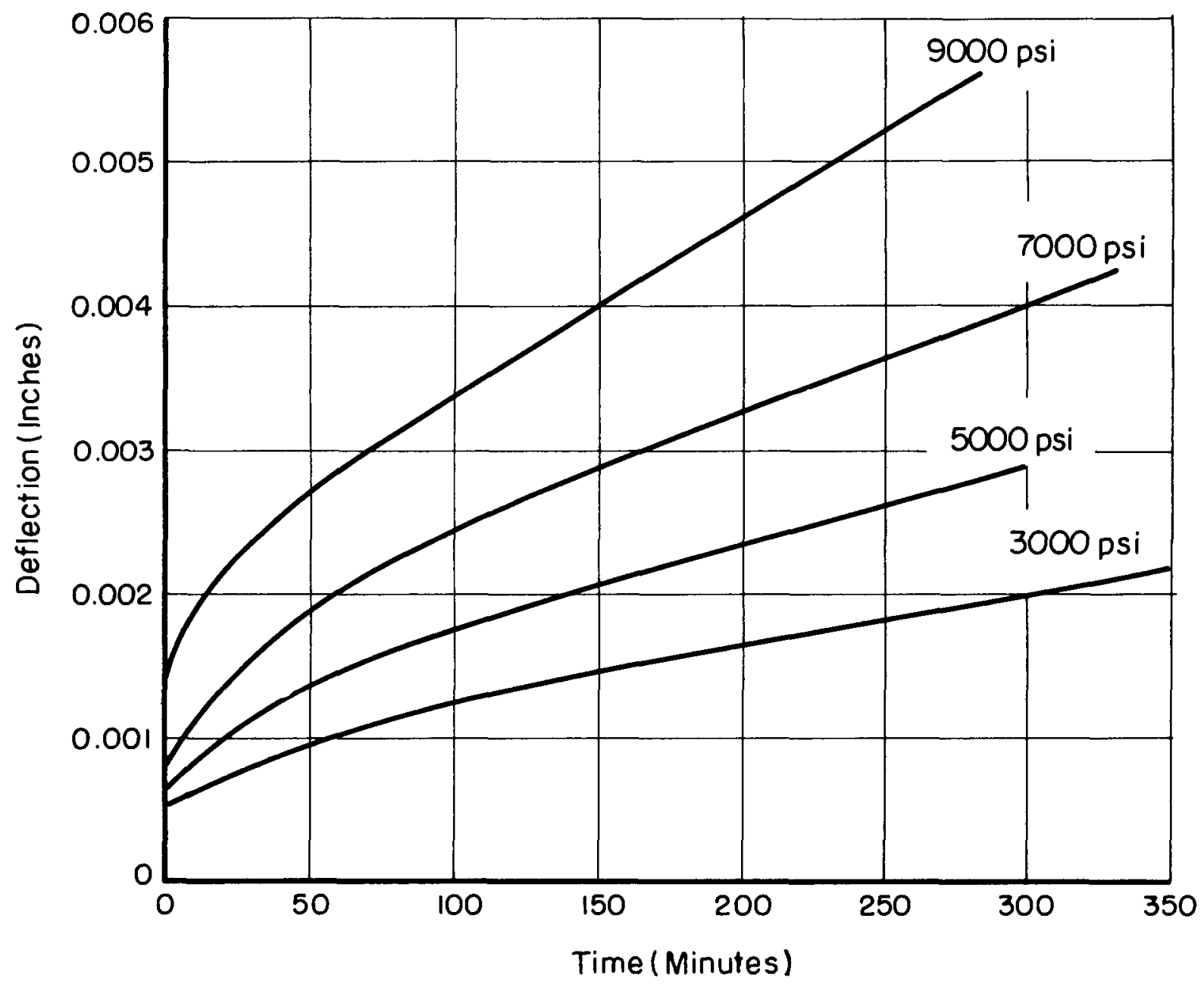

FIGURE C6b. CREEP CURVES FOR $\mathrm{UO}_{2.00}$ AT $1300 \mathrm{C}^{(20)}$ 


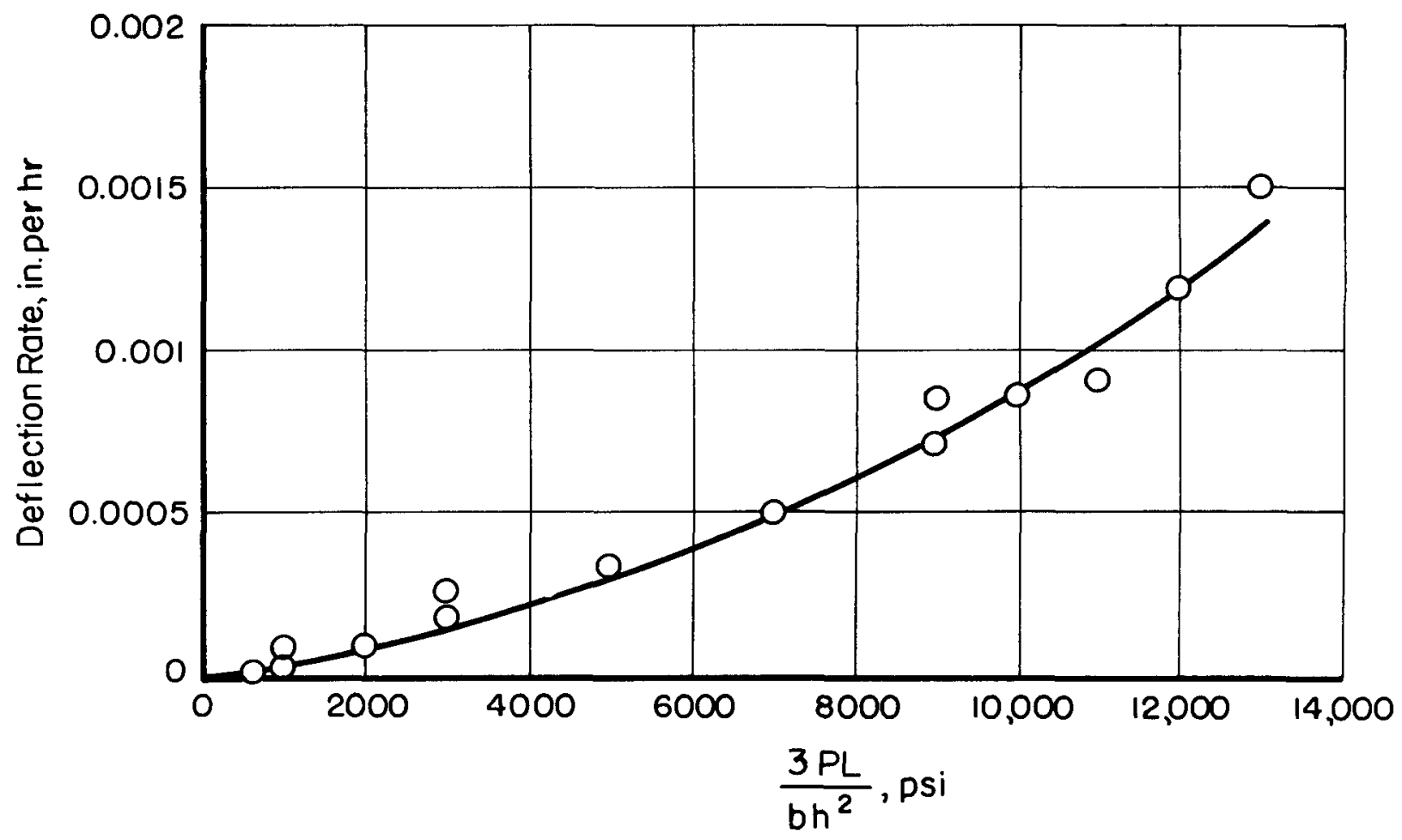

FIGURE C6C. DEFLECTION - RATE DEPENDENCE ON APPLIED STRESS FOR $\mathrm{UO}_{2}$ AT $1300 \mathrm{C} \mathrm{IN} \mathrm{HYDROGEN}^{(20)}$ 
TABLE C7. ELASTIC PROPERTIES OF $\mathrm{UO}_{2}$ AT ROOM TEMPERATURE ${ }^{(21)}$

\begin{tabular}{|c|c|c|c|c|c|c|c|c|c|}
\hline \multirow[b]{2}{*}{ Type of $\mathrm{UO}_{2}$} & \multirow{2}{*}{$\begin{array}{c}\text { Bulk } \\
\text { Density, } \\
\% \text { TD }\end{array}$} & \multicolumn{3}{|c|}{$\begin{array}{c}\text { Young's Modulus(a), } \\
10^{6} \mathrm{psi}\end{array}$} & \multirow{2}{*}{$\begin{array}{l}\text { Shear Modulus (b), } \\
10^{6} \mathrm{psi}\end{array}$} & \multicolumn{2}{|c|}{$\begin{array}{c}\text { Poisson's } \\
\text { Ratio }\end{array}$} & \multicolumn{2}{|c|}{$\begin{array}{l}\text { Bulk Modu- } \\
\text { lus(d), } 10^{6} \text { psi } \\
\end{array}$} \\
\hline & & $E_{L}$ & $\mathrm{E}_{\mathrm{FW}}$ & $\mathrm{E}_{\mathrm{FL}}$ & & $\mu_{L}$ & $\mu_{\mathrm{FW}}$ & $\mathrm{K}_{\mathrm{L}}$ & $\mathrm{K}_{\mathrm{FW}}$ \\
\hline
\end{tabular}

(a) $E_{L}=$ Young's modulus calculated from the longitudinal resonant frequency. $E_{F W}=$ Young's modulus calculated from the flatwise flexural vibration.

$\mathrm{E}_{\mathrm{FL}}=$ Young's modulus calculated from the edgewise flexural vibration.

(b) Shear modulus calculated from the torsional resonant frequency.

(c) $\mu=\frac{E}{2 G}-1$.

(d) $K=\frac{E}{3(1-2 \mu)}$. 
9. Bulk modulus (21)

See Table C7.

10. Poisson's ratio(21)

See Table C7.

D1. Specific heat $(3,23)$

a. Heat capacity at constant pressure:

$\mathrm{C}_{\mathrm{p}}=18.45+2.431 \times 10^{-3} \mathrm{~T}-2272 \times 10^{5} \mathrm{~T}^{-2} \mathrm{cal} /(\mathrm{g}$ mole $)(\mathrm{C})$.

b. Table of specific heats calculated from above expression:

Temperature, $\mathrm{C}$

100

200

500

1000

1500
Specific Heat, cal/(g)(C)

0.063

0.067

0.074

0.078

0.082

2. Thermal conductivity $(1,24-34)$

a. See Figures D2a and D2b and Tables D2a and D2b.

b. An empirical equation for thermal conductivity of 100 per cent dense $\mathrm{UO}_{2}$ from 800 to $2100 \mathrm{C}$ is as follows:

$$
\mathrm{K}=\frac{1}{17.3+0.016 \mathrm{~T}} \mathrm{w} /(\mathrm{cm})(\mathrm{C})
$$

where $\mathrm{T}=$ Temperature, $\mathrm{K}$.

\section{E1. Electrical resistivity $(1)$}
a. Typical values of electrical conductivity are shown in Figure Ela.
b. Effect of nonstoichiometry on electrical conductivity is shown in Figure Elb. 


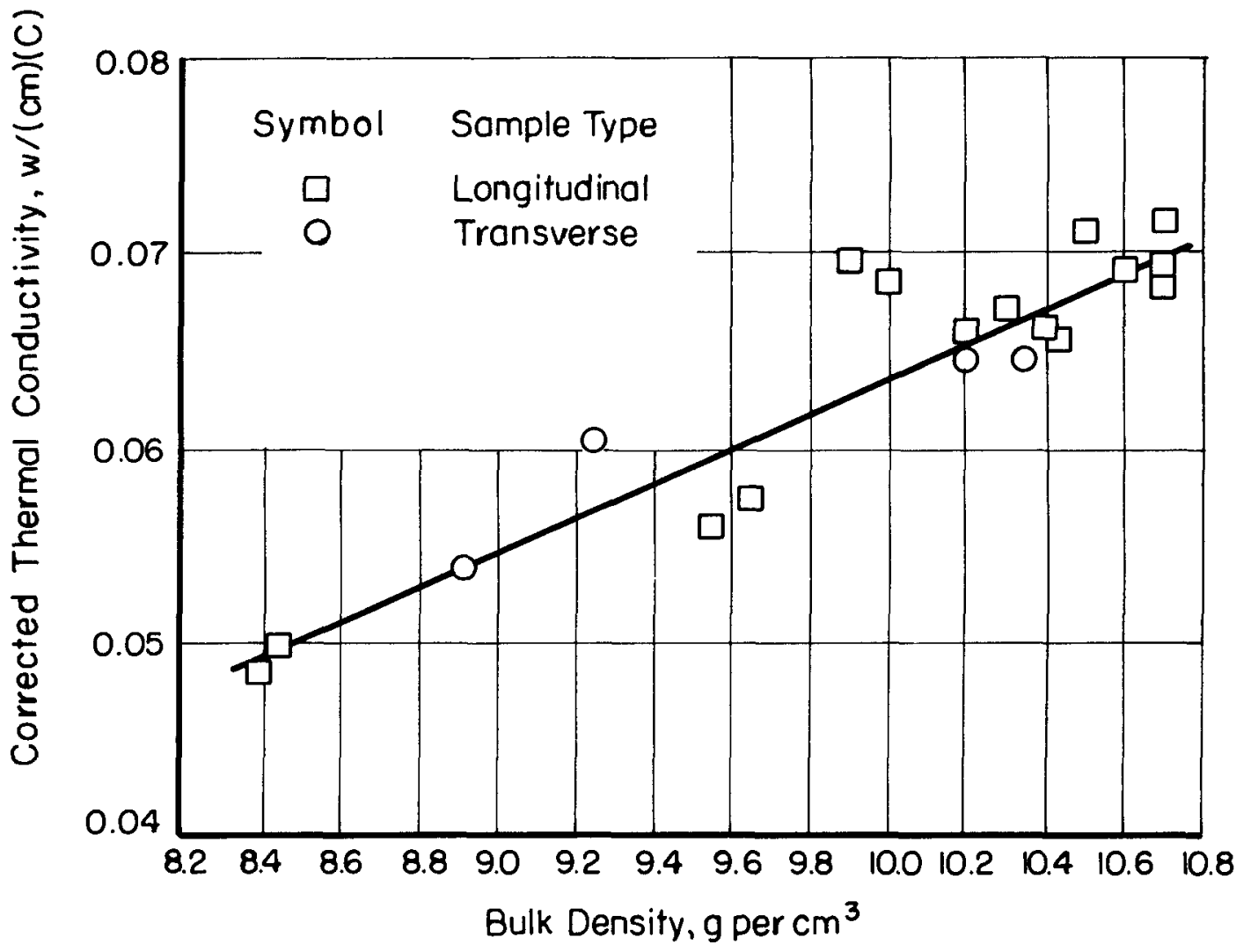

FIGURE D2a. VARIATION OF THERMAL CONDUCTIVITY (CORRECTED TO ZERO POROSITY) WITH BULK DENSITY ${ }^{(24)}$ 


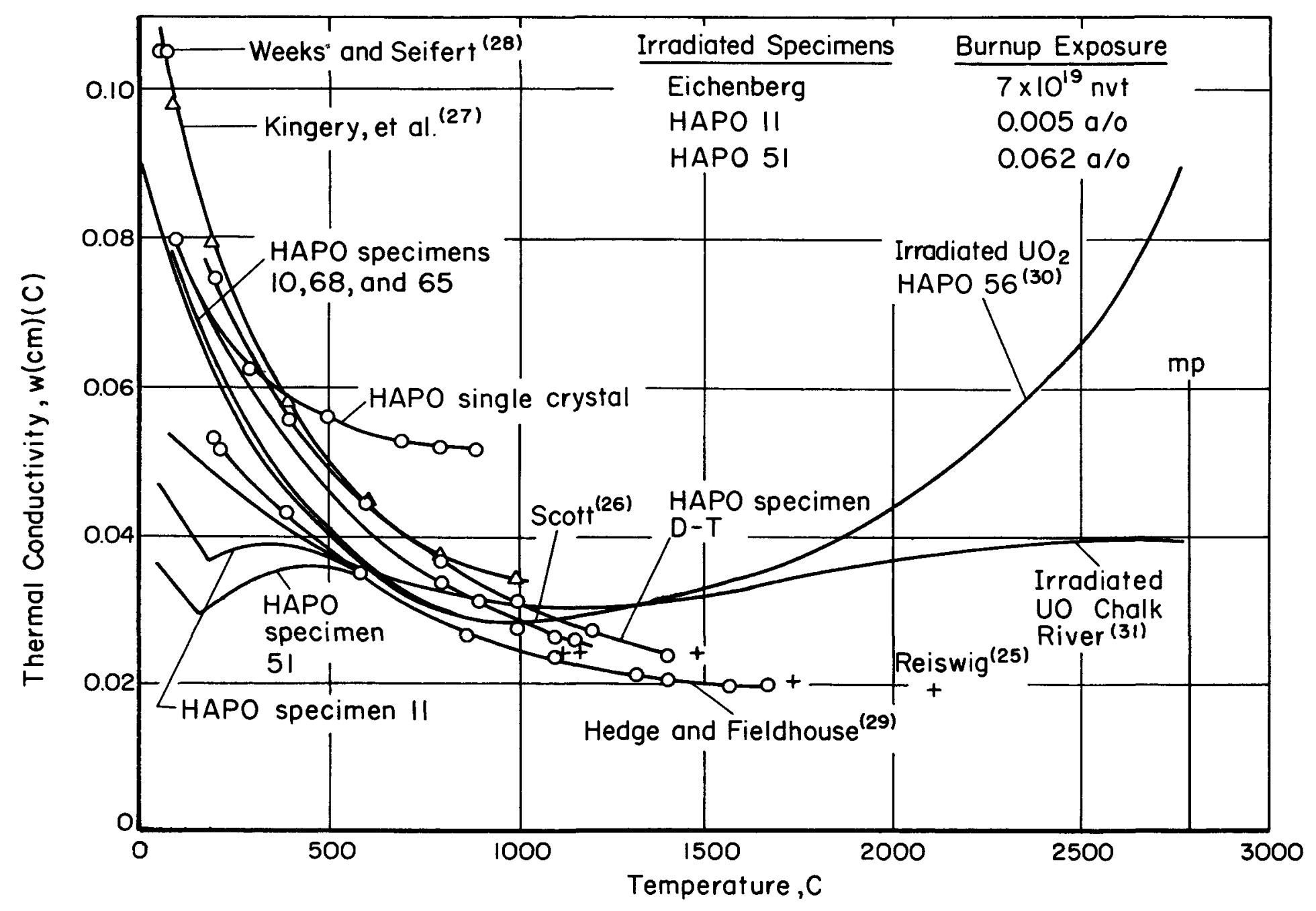

FIGURE D2b. THERMAL CONDUCTIVITY OF $\mathrm{UO}_{2}{ }^{(30,32)}$

All values have been adjusted linearly with density to 100 per cent theoretical. 
TABLE D2a. THERMAL CONDUCTIVITY FOR STOICHIOMETRIC UO ${ }_{2}^{(1)}$

\begin{tabular}{|c|c|c|c|c|c|}
\hline $\begin{array}{c}\text { Oxygen/Uranium } \\
\text { Ratio }\end{array}$ & $\begin{array}{l}\text { Density, } \\
\text { g per } \mathrm{cm}^{3}\end{array}$ & Atmosphere & $\begin{array}{c}\text { Temperature, } \\
\mathbf{C} \\
\end{array}$ & $\begin{array}{c}\text { Thermal } \\
\text { Conductivity for } \\
100 \text { Per Cent } \\
\text { Dense UO } 2 \\
\text { (Calculated), } \\
\text { w/(cm)(C) }\end{array}$ & Reference \\
\hline \multirow[t]{5}{*}{2.00} & 8.00 & Vacuum & 200 & 0.0815 & $(27)$ \\
\hline & & & 400 & 0.0590 & \\
\hline & & & 600 & 0.0452 & \\
\hline & & & 800 & 0.0376 & \\
\hline & & & 1000 & 0.0351 & \\
\hline \multirow[t]{2}{*}{2.00} & 10.08 & Vacuum & 100 & 0.105 & (33) \\
\hline & & & 150 & 0.0908 & \\
\hline \multirow{3}{*}{$\begin{array}{l}2.00 \text { reduced } \\
\text { from } 2.09\end{array}$} & 10.55 & Vacuum & 60 & 0.115 & (33) \\
\hline & & & 70 & 0.114 & \\
\hline & & & 80 & 0.114 & \\
\hline \multirow[t]{10}{*}{2.00} & 8.17 & Helium & 200 & 0.0524 & (29) \\
\hline & & & 215 & 0.0510 & \\
\hline & & & 390 & 0.0428 & \\
\hline & & & 640 & 0.0348 & \\
\hline & & & 870 & 0.0264 & \\
\hline & & & 1100 & 0.0234 & \\
\hline & & & 1320 & 0.0209 & \\
\hline & & & 1400 & 0.0199 & \\
\hline & & & 1560 & 0.0190 & \\
\hline & & & 1670 & 0.0193 & \\
\hline \multirow[t]{5}{*}{2.00} & 10.5 & Hydrogen & 800 & 0.0340 & $(26)$ \\
\hline & & & 900 & 0.0310 & \\
\hline & & & 1000 & 0.0275 & \\
\hline & & & 1100 & 0.0260 & \\
\hline & & & 1150 & 0.0255 & \\
\hline
\end{tabular}


TABLE D2b. EFFECT OF COMPOSITION ON THERMAL CONDUCTIVITIES OF URANIUM OXIDES(1)

\begin{tabular}{|c|c|c|c|c|c|}
\hline \multirow[b]{2}{*}{$\begin{array}{c}\text { Uranium/Oxygen } \\
\text { Ratio } \\
\end{array}$} & \multicolumn{5}{|c|}{ Conductivity for } \\
\hline & $\begin{array}{l}\text { Density, } \\
\text { g per } \mathrm{cm}^{3}\end{array}$ & $\begin{array}{c}\text { Theoretical } \\
\text { Density, } \\
\text { g per } \mathrm{cm}^{3} \\
\end{array}$ & $\begin{array}{c}100 \text { Per Cent } \\
\text { Dense UO }{ }^{(a)} \\
w /(\mathrm{cm})(\mathrm{C})\end{array}$ & $\begin{array}{c}\text { Relative } \\
\text { Conductivity } \\
\text { per cent }\end{array}$ & Reference \\
\hline 2.00 & 10.55 & 10.96 & $0.115(\mathrm{~b})$ & 100 & (33) \\
\hline 2.00 & 10.00 & 10.96 & 0.092 & 100 & (34) \\
\hline 2.01 & 10.30 & 10.97 & 0.071 & 100 & (24) \\
\hline $2.01(\mathrm{c})$ & 10.25 & 10.97 & 0.0535 & 100 & (24) \\
\hline 2.04 & 10.30 & 11.02 & 0.064 & 90 & (24) \\
\hline 2.055 & 10.30 & 11.03 & 0.061 & 86 & $(24)$ \\
\hline $2.055(\mathrm{c})$ & 10.25 & 11.03 & 0.043 & 80 & (24) \\
\hline 2.07 & 10.30 & 11.06 & 0.054 & 76 & (24) \\
\hline 2.08 & 10.30 & 11.07 & 0.0495 & 67 & (24) \\
\hline $2.09(\mathrm{c})$ & 10.25 & 11.08 & 0.031 & 58 & $(24)$ \\
\hline 2.09 & 10.55 & 11.08 & $0.071^{(d)}$ & 62 & (33) \\
\hline 2.095 & 10.30 & 11.09 & 0.0395 & 53 & (24) \\
\hline 2.11 & 10.30 & 11.11 & 0.033 & 46.5 & (24) \\
\hline $2.14^{(c)}$ & 10.25 & 11.15 & 0.0225 & 42 & (24) \\
\hline 2.16 & 10.8 & 11.18 & 0.035 & 38 & (34) \\
\hline 2.19 & 9.83 & 11.22 & $0.035(\mathrm{e})$ & 30 & (33) \\
\hline 2.21 & 10.6 & 11.25 & $0.018^{(f)}$ & 25 & (24) \\
\hline $2.26(\mathrm{c}, \mathrm{g})$ & 8.05 & 8.4 & 0.018 & 25 & (24) \\
\hline
\end{tabular}

\footnotetext{
(a) Measurements at $60 \mathrm{C}$ except where noted.

(b) $58 \mathrm{C}$.

(c) $0.1 \mathrm{w} / 0 \mathrm{TiO}_{2}$ addition.

(d) $57 \mathrm{C}$.

(e) $53 \mathrm{C}$.

(f) Average of three specimens.

(g) $\mathrm{U}_{3} \mathrm{O}_{8}$ plus trace amount of $\mathrm{UO}_{2}$.
} 


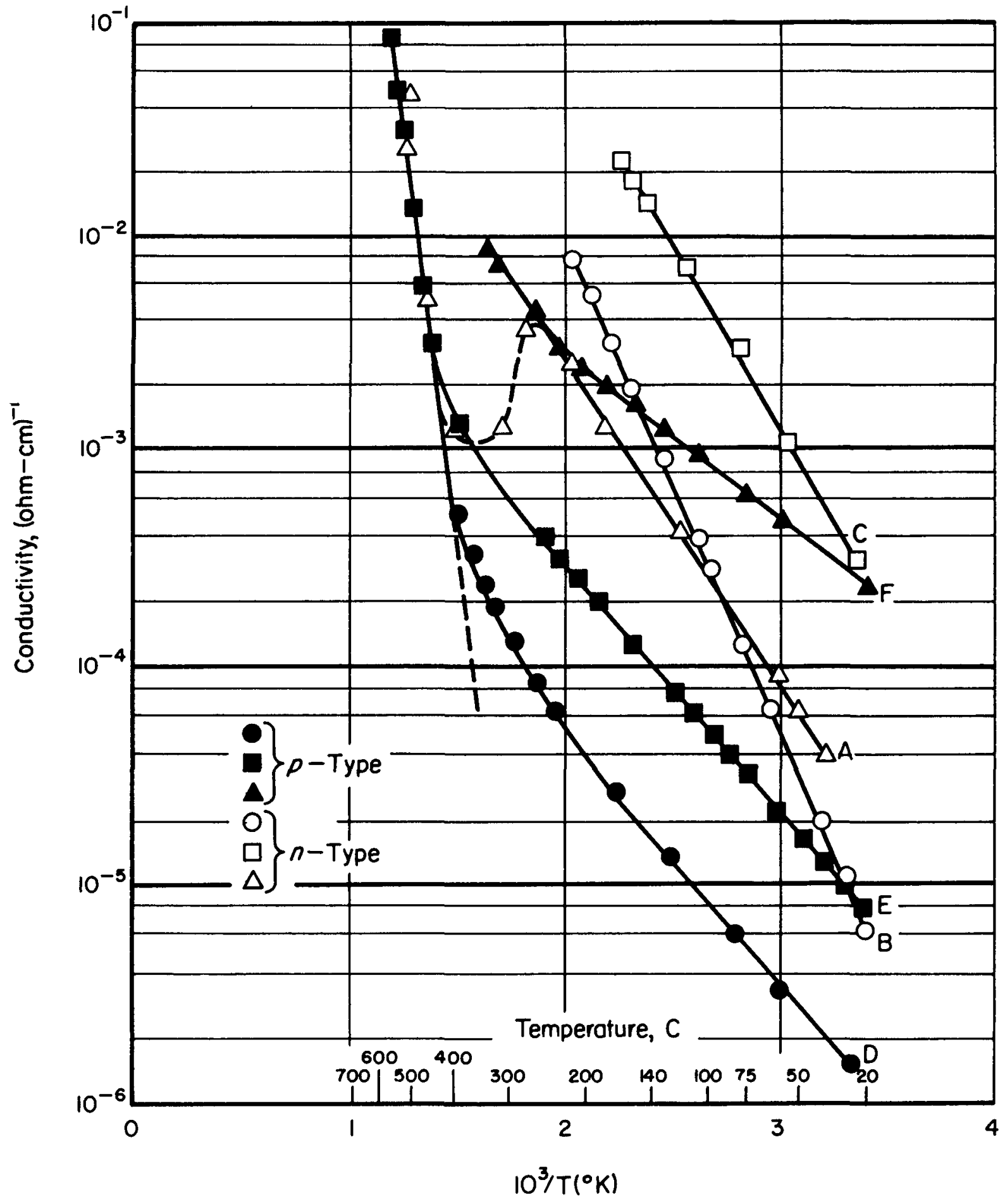

FIGURE EIO. CONDUCTIVITY OF SINTERED SPECIMENS OF $n$-AND $p$-TYPE $\mathrm{UO}_{2}^{(1)}$ 


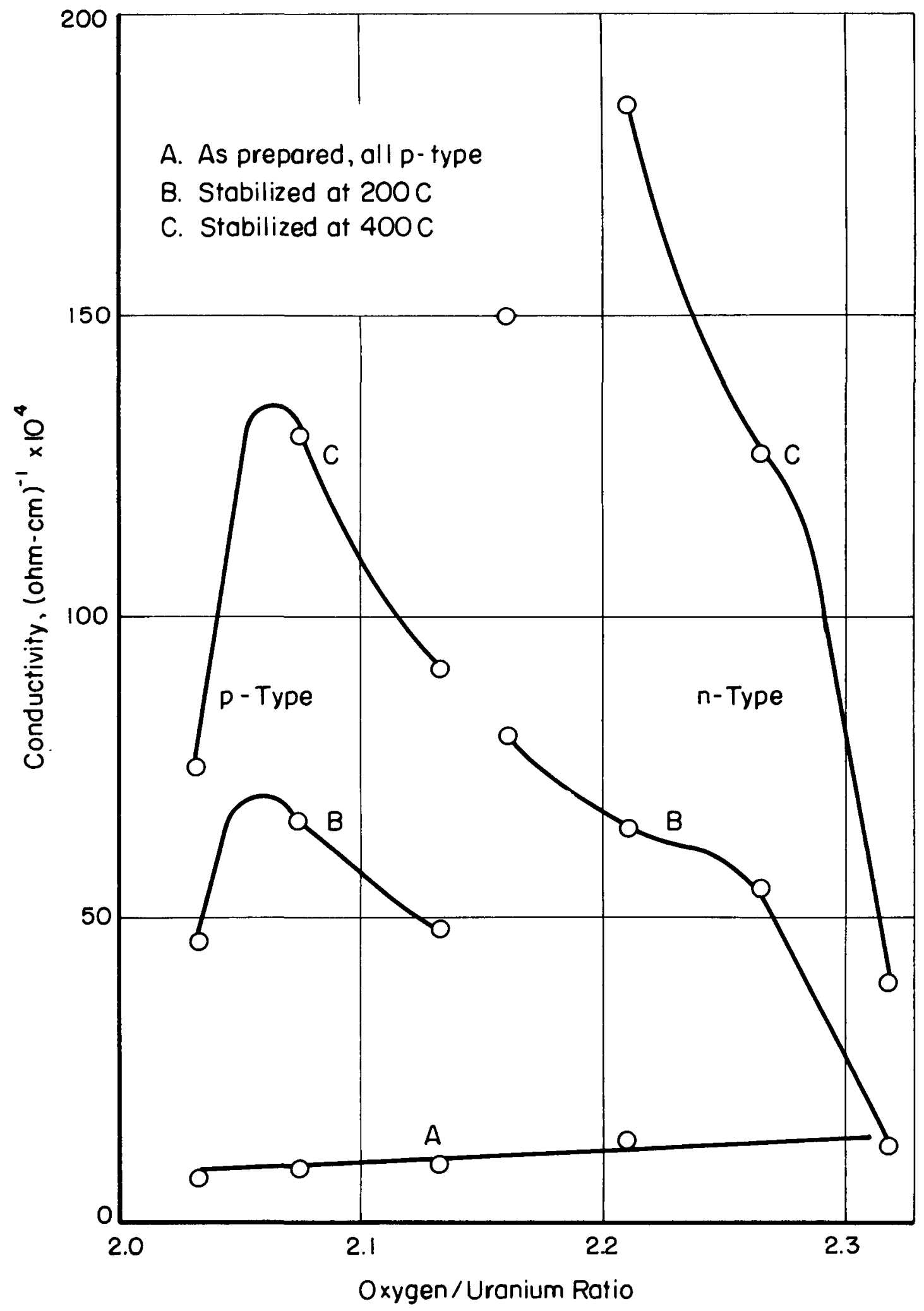

FIGURE EIb. ROOM-TEMPERATURE ELECTRICAL CONDUCTIVITY AS A FUNCTION OF OXYGEN /URANIUM RATIO OF PRESSED SPECIMENS OF $\mathrm{UO}_{2}{ }^{(1)}$ 
F1. Reaction with coolants $(1,11,35-37)$

a. Steam

\begin{tabular}{|c|c|c|c|}
\hline Specimen & Test Conditions & $\begin{array}{c}\text { Average } \\
\text { Weight Loss, } \\
\text { per cent } \\
\end{array}$ & $\begin{array}{c}\mathrm{U}(\mathrm{VI}) \\
\text { Content } \\
\text { After Test, w/o } \\
\end{array}$ \\
\hline $\begin{array}{l}\text { Cold pressed and } \\
\text { sintered }\end{array}$ & $\begin{array}{c}302 \mathrm{hr} \text { in degassed } \\
\text { steam at } 750 \mathrm{~F} \\
\text { and } 2000 \mathrm{psig}\end{array}$ & 0.04 & $\begin{array}{l}0.27 \\
0.64 \\
0.50\end{array}$ \\
\hline Hot pressed & $\begin{array}{l}302 \mathrm{hr} \text { in degassed } \\
\text { steam at } 750 \mathrm{~F} \\
\text { and } 2000 \mathrm{psig}\end{array}$ & 0.42 & 0.43 \\
\hline
\end{tabular}

b. Helium

No reaction occurs from room temperature to the $\mathrm{UO}_{2}$ melting point.

c. Carbon dioxide

At $1292 \mathrm{~F}, \mathrm{UO}_{2}\left(\rho=9.6 \mathrm{~g}\right.$ per $\left.\mathrm{cm}^{3}\right)$ exhibited a weight change of 0.008 $\mathrm{mg} /\left(\mathrm{cm}^{2}\right)(\mathrm{hr})$.

d. Hydrogen

No reaction up to the melting point of $\mathrm{UO}_{2}$ occurs.

2. Reactions with cladding or structural materials $(34,38,39)$

\section{Material}
a. Niobium-base alloys
b. Zirconium
c. Nickel-base alloys

d. Iron-base alloys

e. Stainless steel

f. Chromium-base alloys

g. Tungsten

h. Tantalum

i. Molybdenum

j. Rhenium
Reaction With $\mathrm{UO}_{2}$
None to $2300 \mathrm{~F}$
Reaction at $1500 \mathrm{~F}$
No reaction at $2000 \mathrm{~F}$; reaction at $2500 \mathrm{~F}$
No reaction at $2000 \mathrm{~F}$
No reaction at $600 \mathrm{~F}$
No reaction at $2000 \mathrm{~F}$
First reaction at $1785 \mathrm{C}$; fast reaction at $2065 \mathrm{~F}$
First reaction at $2295 \mathrm{C}$; fast reaction at $2420 \mathrm{C}$
First reaction at $2155 \mathrm{C}$
First reaction at $925 \mathrm{C}$;
fast reaction at $2295 \mathrm{C}$ 
G1. Dimensional stability during irradiation $(40-42)$

a. A density decrease of 0.33 per cent per a/o of burnup resulted at a burnup of 53 per cent. $(40,41)$

b. A density decrease of 0.5 per cent per a/o of burnup was observed in water cooled flat plate fuels. (42)

\section{Fission-gas-release data}

a. Postirradiation diffusion

(1) At low burnup, or by neutron activation, diffusion coefficients in sintered $\mathrm{UO}_{2}$ are found to depend upon the experimental conditions, and are believed to depend upon the oxygen/uranium ratio, although the latter has not been proved.

(a) In reducing atmosphere (helium-5 volume per cent hydrogen) the following data have been obtained for sintered $\mathrm{UO}_{2}:(1,43)$

$$
\begin{aligned}
& D_{\mathrm{Xe}}=6.6 \times 10^{-6} \mathrm{e}^{(-71,700 / \mathrm{RT})} \\
& \mathrm{D}_{\mathrm{Xe}}=7.8 \times 10^{-6} \mathrm{e}^{(-71,000 / \mathrm{RT})} \\
& \mathrm{D}_{\mathrm{Kr}} \text { data are similar. }
\end{aligned}
$$

(b) Other data for a neutral atmosphere, a gettered atmosphere, and a gettered (in presence of tantalum) vacuum gave variable activation energies for xenon diffusion, the activation energy increasing apparently with increased gettering or as the oxygen/uranium ratio approaches 2.00 .

Neutral atmosphere:(44)

$$
D_{X e}=1.5 \times 10^{-8} e^{(-46,000 / R T)} \text {. }
$$

Gettered atmosphere:(45)

Activation energy $=115,000 \mathrm{cal}$ per $\mathrm{g}$ mole

$\mathrm{D}_{\mathrm{Xe}}$ at $1400 \mathrm{C}=2 \times 10^{-15} \mathrm{~cm}^{2}$ per sec.

Gettered vacuum: ${ }^{(46)}$

Activation energy $=125,000 \mathrm{cal}$ per g mole

$\mathrm{D}_{\mathrm{Xe}}$ at $1400 \mathrm{C}=5 \times 10^{-16} \mathrm{~cm}^{2}$ per sec.

(c) For other data see Reference (1). 
(2) Effects of increasing burnup upon gas release do not appear to be serious for water-cooled pin-type fuel elements up to $25,000 \mathrm{MWD} / \mathrm{T}$. For example(1), comparison between calculated (based on diffusion measurements) and observed $\mathrm{Kr}^{85}$ releases for sintered oxides of 86 to 96 per cent density, exposed at heat fluxes of 40,000 to 300,000 $\mathrm{Btu} /(\mathrm{hr})\left(\mathrm{ft}^{2}\right)$ for burnups between 1,000 and 13,000 $\mathrm{MWD} / \mathrm{T}$ are shown in Figure G2a. Similarly, the variation of $D_{X e}^{\prime}=D / a^{2}$ (where $a=\frac{3 d}{s}$, $\mathrm{d}=$ fraction of theoretical density, $\mathrm{s}=$ surface area in $\mathrm{cm}$ per $\mathrm{cm}^{3}$ ) with burnup is also shown in Figure G2b for gas-cooled reactor conditions. (47) No significant increase is believed to occur for burnups up to $16,400 \mathrm{MWD} / \mathrm{T}$, the scatter being largely accounted for by the uncertainties in the surface areas. (Correlation was established by assuming an activation energy of 70,000 cal per $g$ mole and correcting $D^{\prime}$ to $1400 \mathrm{C}$. Specimens with temperature above $1600 \mathrm{C}$ were not considered.) On the other hand, flat-plate specimens irradiated at average temperatures well below $1000 \mathrm{C}$ showed an apparent large increase in diffusion coefficient of $\mathrm{Kr} 85$ at $1000 \mathrm{C}$ with increasing burnup, as shown in Figure G2c. (1) These results were obtained by postirradiation heating and show significant burnup effects at burnups above 25,000 MWD/T for these conditions. Similar effects may or may not occur when irradiations are conducted at higher temperatures.

b. In-pile diffusion

Low-burnup in-pile measurements of fission-gas release from $\mathrm{UO}_{2}$ in helium-5 volume per cent hydrogen yield the following conclusions (48):

(1) Xenon and krypton diffusion are about equal at temperatures up to $3000 \mathrm{~F}$.

(2) Iodine diffusion rates are about equal to xenon for the above temperatures, and iodine is not a significant contributor in a practical fuel element. Bromine effects on krypton are nil.

(3) Diffusion coefficients obtained by neutron activation are adequate to characterize the low-burnup behavior of rare gases in $\mathrm{UO}_{2}$.

c. Model for diffusion

The model for diffusion release of xenon and krypton from sintered $\mathrm{UO}_{2}$ is adequately represented by assuming a spherical geometry with the appropriate surface-to-volume ratio. (1) It is likely that a flat-plate geometry of appropriate surface-to-volume ratio would be more precise in some cases, but the maximum differences between the two models is only 14 per cent of the predicted release. (48) 


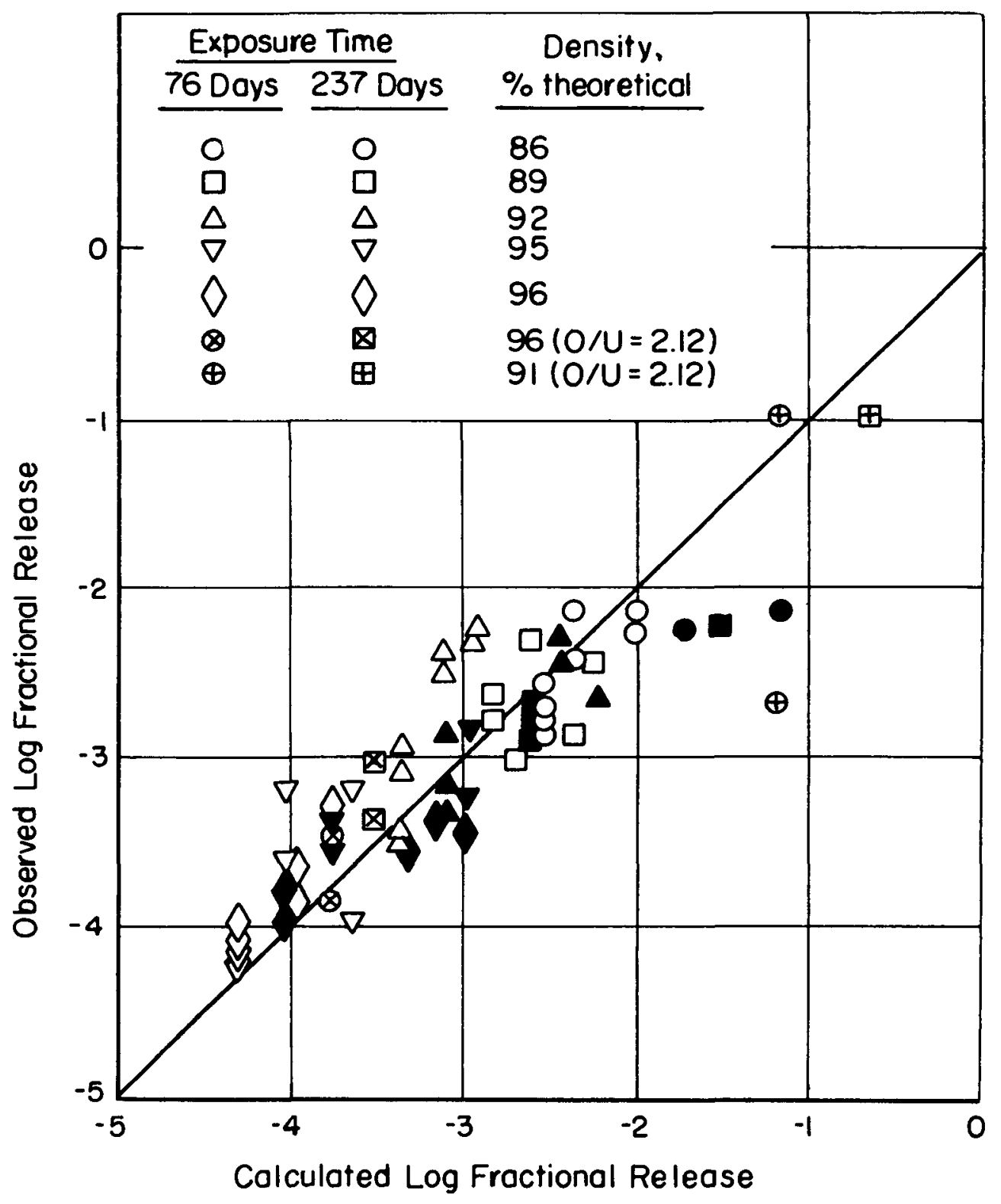

FIGURE G2a. CALCULATED AND OBSERVED FRACTIONAL FISSION-GAS RELEASE $\left(\mathrm{Kr}^{85}\right)^{(1)}$ 


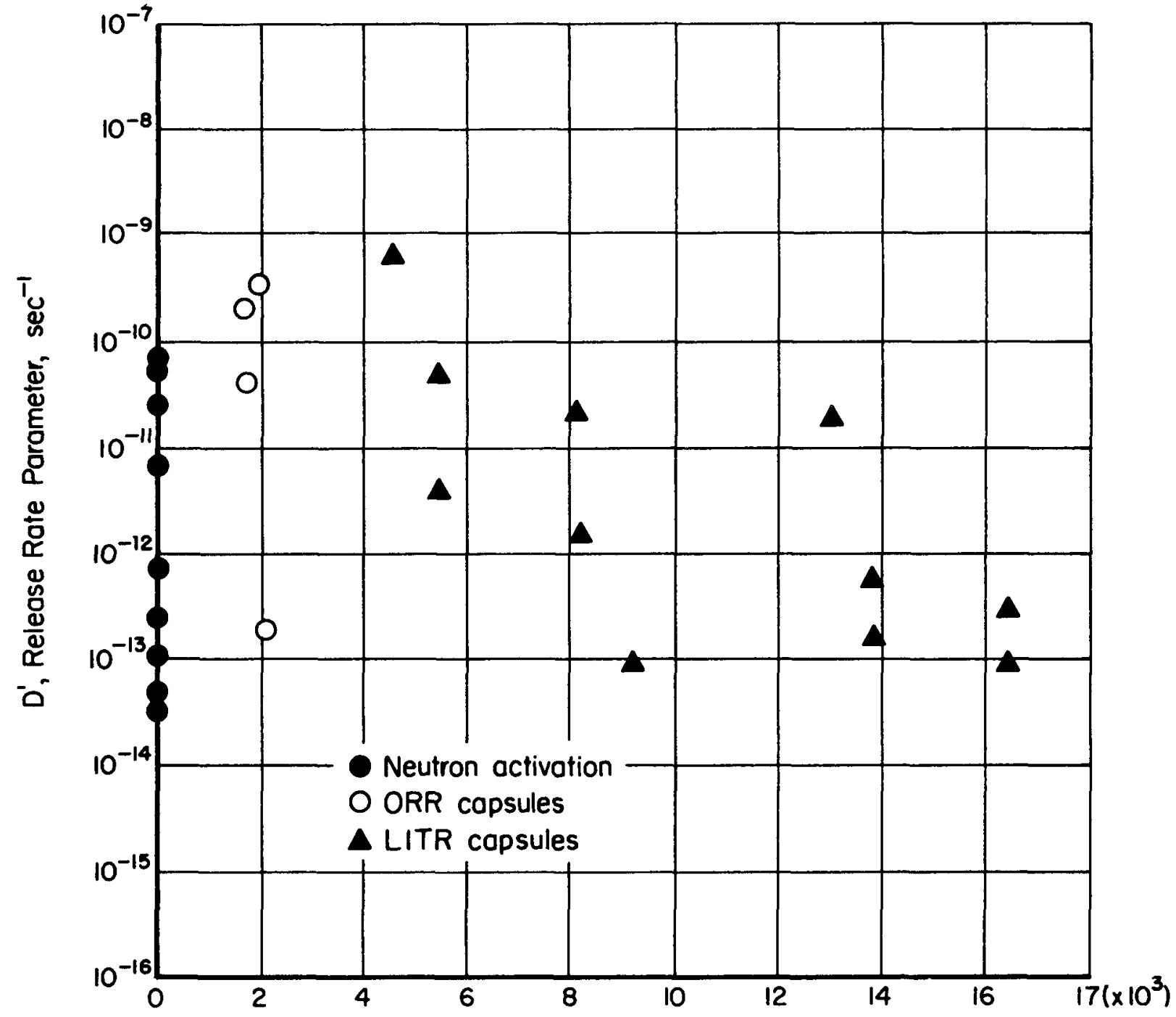

Burnup, Mwd/MT

FIGURE G2b. RELATIONSHIP BETWEEN D' VALUES AT $1400 \mathrm{C}$ AND BURNUP FOR $U_{2}$ SAMPLES WITH DENSITIES ABOVE $10 \mathrm{~g}$ per $\mathrm{cm}^{3}$ 


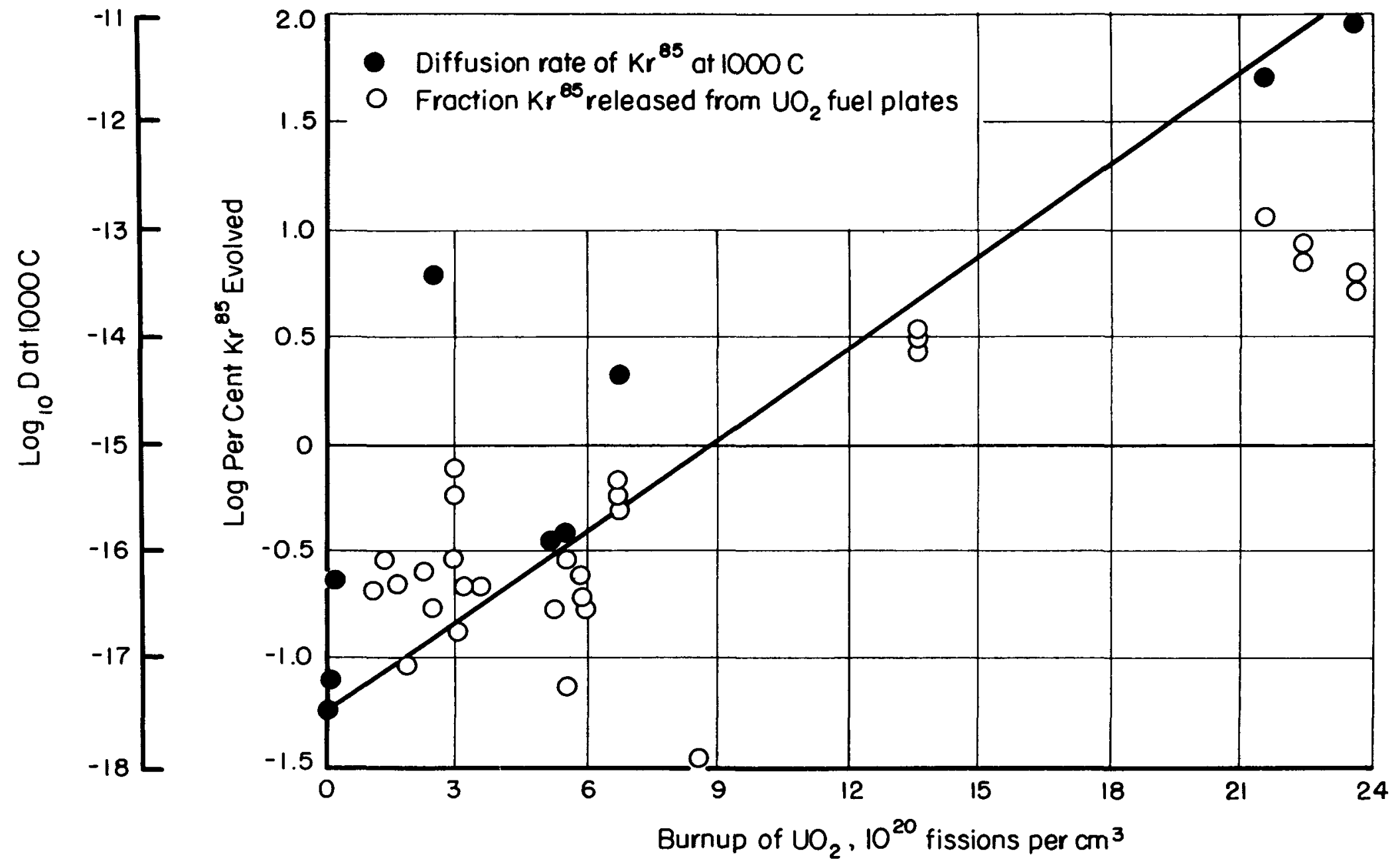

FIGURE G2C. VARIATION OF DIFFUSION RATE AND RELEASE OF $\mathrm{kr}^{85}$ FROM DENSE $\mathrm{UO}_{2}{ }^{(1)}$ 
d. Other mechanisms of gas release

It appears, especially in high-heat rating elements, that many mechanisms othe $r$ than diffusion are acting. Some of these mechanisms are significant, indicating that correlation between diffusion-model predictions and observed releases are fortuitous. Further discussions of other mechanisms of gas release are in the literature. $(1,30,49-51)$. See also the correlation of gas release with heat rating below.

e. Correlation of gas release with heat rating

A surprising agreement between predictions by a simple diffusion model and observed releases at low burnup as a function of heat generation is illustrated in Figure G2d.(31) Selection of only one arbitrary parameter was necessary to obtain a good fit between calculated and experimental data.

\section{Swelling-temperature data}

Swelling has been observed in bulk $\mathrm{UO}_{2}$ water-cooled fuels as indicated in Figure G3. The center cemperatures are in dispute, but it is apparent that swelling will result when large accumulations of gases occur. The behavior of $\mathrm{UO}_{2}$ fuel elements at gas-cooled reactor conditions, however, may be much different. Additional data are needed for such conditions. The plastic behavior of $\mathrm{UO}_{2}$ at elevated temperatures has been demonstrated. $(1,20,22)$

\section{Unusual nuclear properties}

None

5. Property changes as a result of irradiation $(1,17)$

a. Thermal conductivity: a 33 per cent decrease at $60 \mathrm{C}$ after $1.1 \times 10^{19}$ fissions per $\mathrm{cm}^{3}$. See Figure D2b. (32)

The difference in the Chalk River and HAPO data on irradiated $\mathrm{UO}_{2}$ at above $1500 \mathrm{C}$ is probably due to the differences in irradiation times. The HAPO data are based on long irradiation times during which the the rmal conductivity was improved by sintering and grain growth. The Chalk River data are based on short ir radiations. Additional data have been reported by Eichenberg. (52)

b. Hardness: an increase from 625 to $830 \mathrm{KHN}$ after $2 \times 10^{20}$ fissions per $\mathrm{cm}^{3}$ has been reported. (1)

c. Melting point: an increase of $125 \mathrm{C}$ after $1.5 \times 10^{19}$ fissions per $\mathrm{cm}^{3}$ and a significant reduction after $2 \times 10^{21}$ fissions per $\mathrm{cm}^{3}$ have been reported. $(18,53,54)$ See Figure G5c.

d. Electrical conductivity (18)

See Figure G5d. 


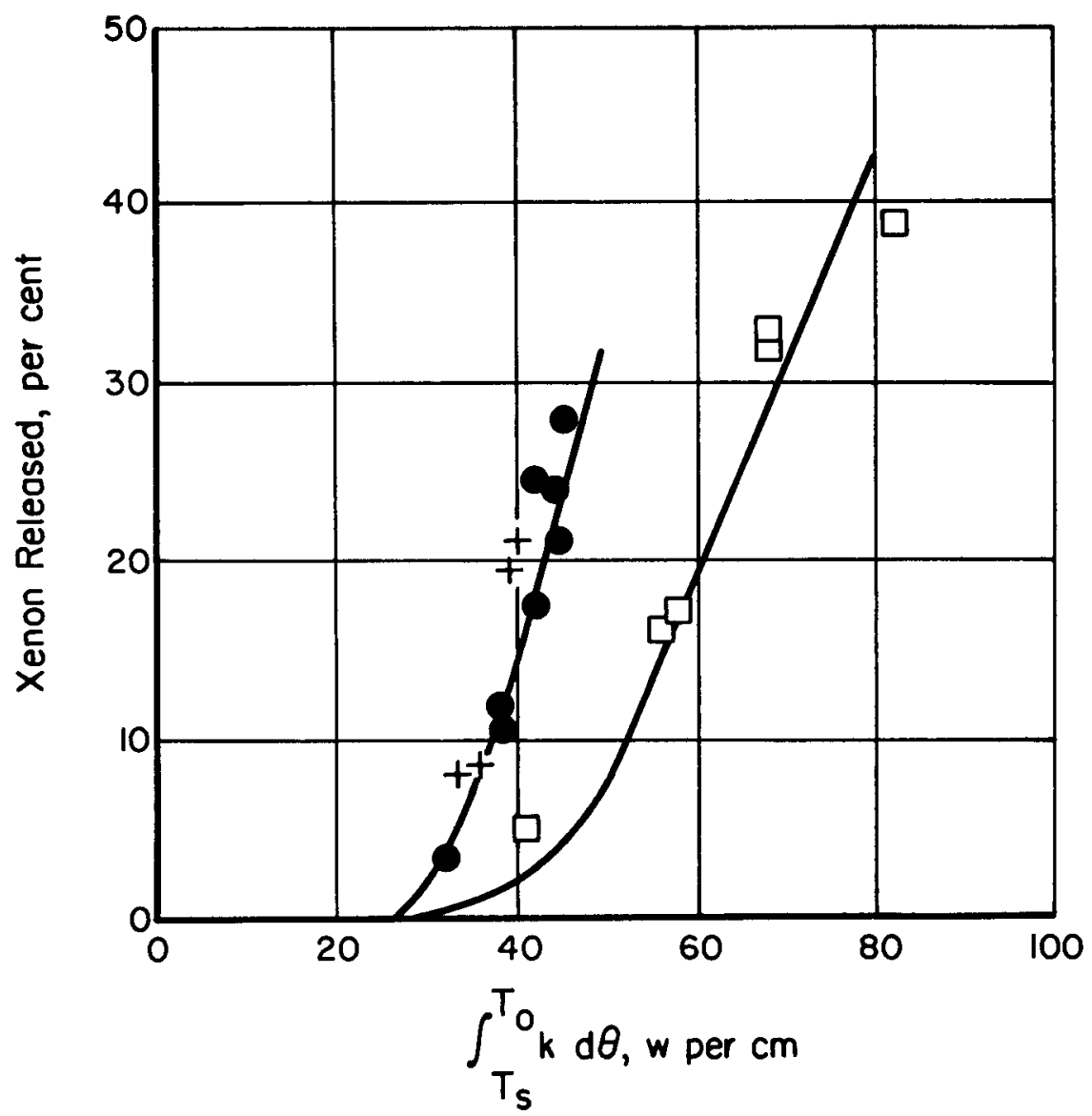

FIGURE G2d THE PERCENTAGE OF FISSION XENON RELEASED FROM SINTERED UO ${ }_{2}$ DURING IRRADIATION AS A FUNCTION OF THE FUEL'S HEAT RATING ${ }^{(31)}$

AEA-43251 


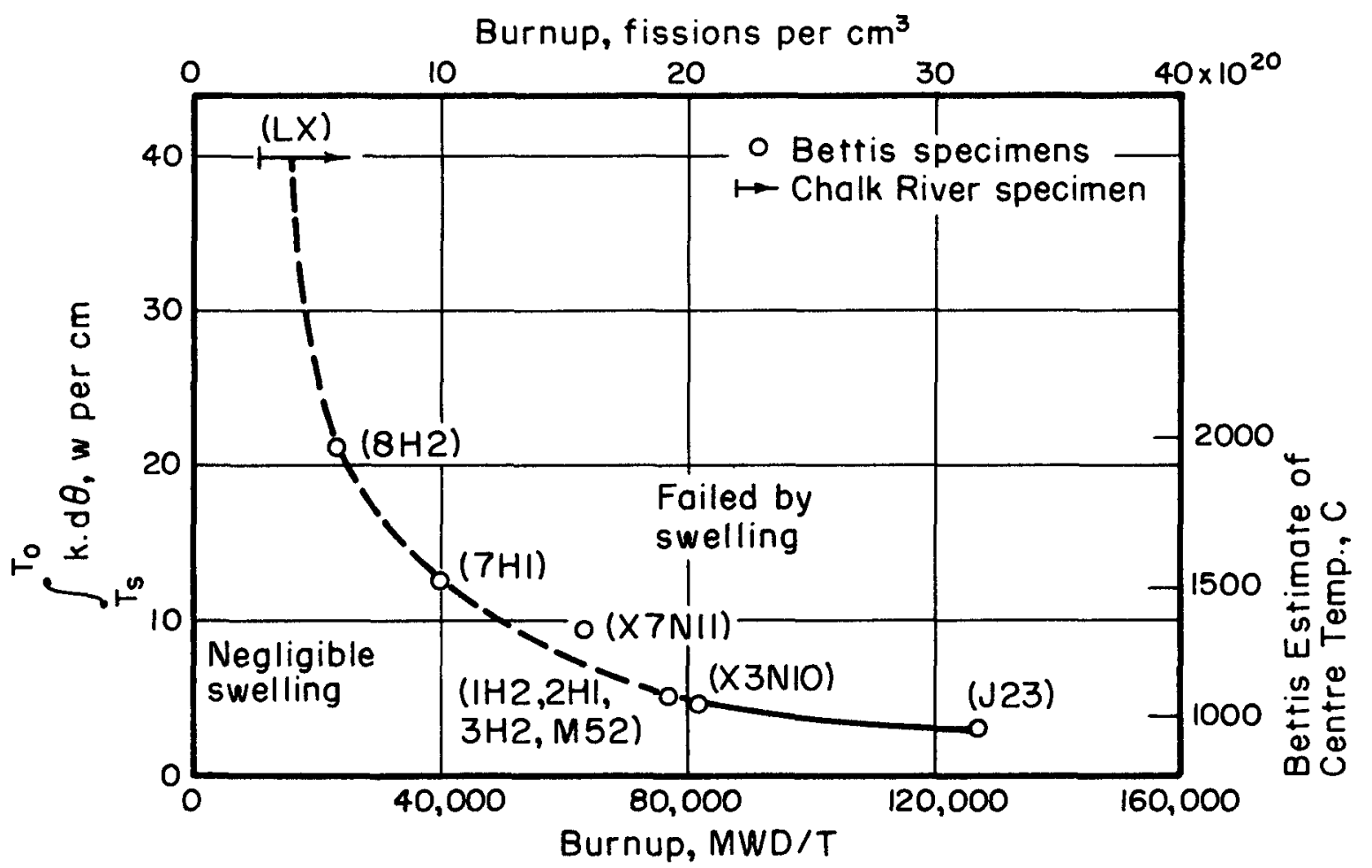

FIGURE G3. THE CORRELATION BETWEEN BURNUP AND HEAT RATING FOR $\mathrm{UO}_{2}$ SPECIMENS THAT FAIL BY SWELLING OF THE FUEL (31)

All specimens were subject to a total restraint of about $200 \mathrm{kgf}$ per $\mathrm{cm}$ (3000 psi). 


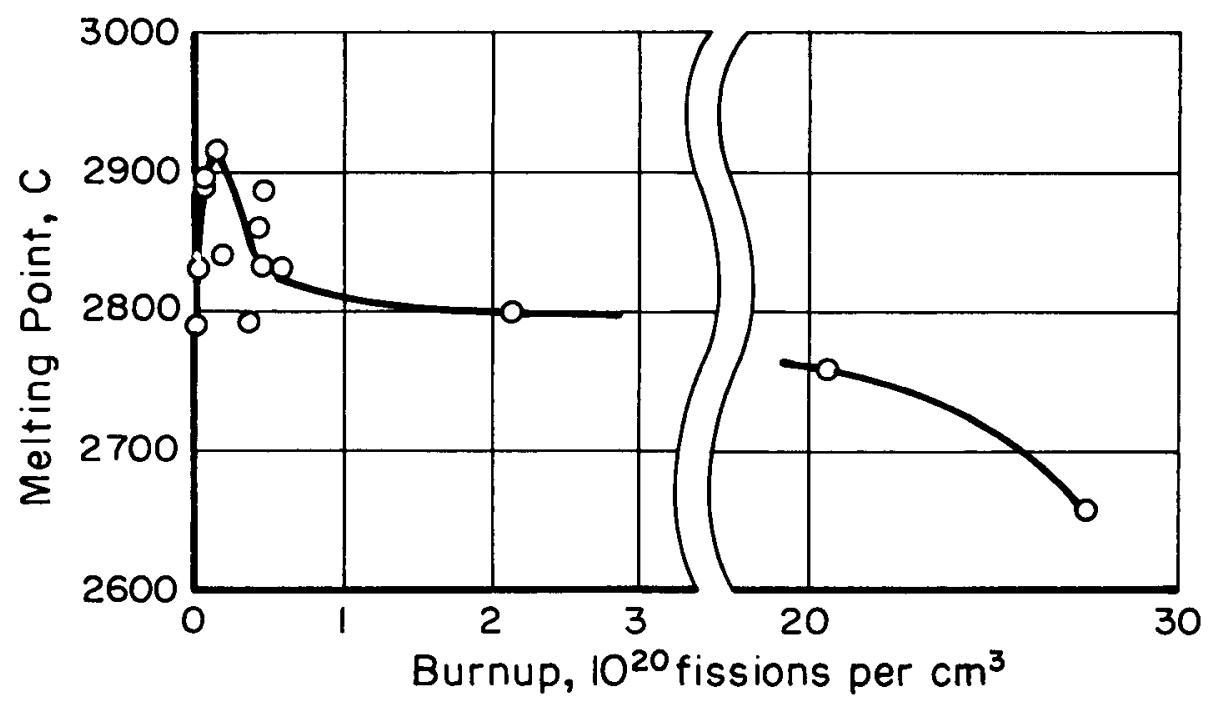

FIGURE G5c. MELTING TEMPERATURE OF IRRADIATED $\mathrm{UO}_{2}{ }^{(18)}$ 


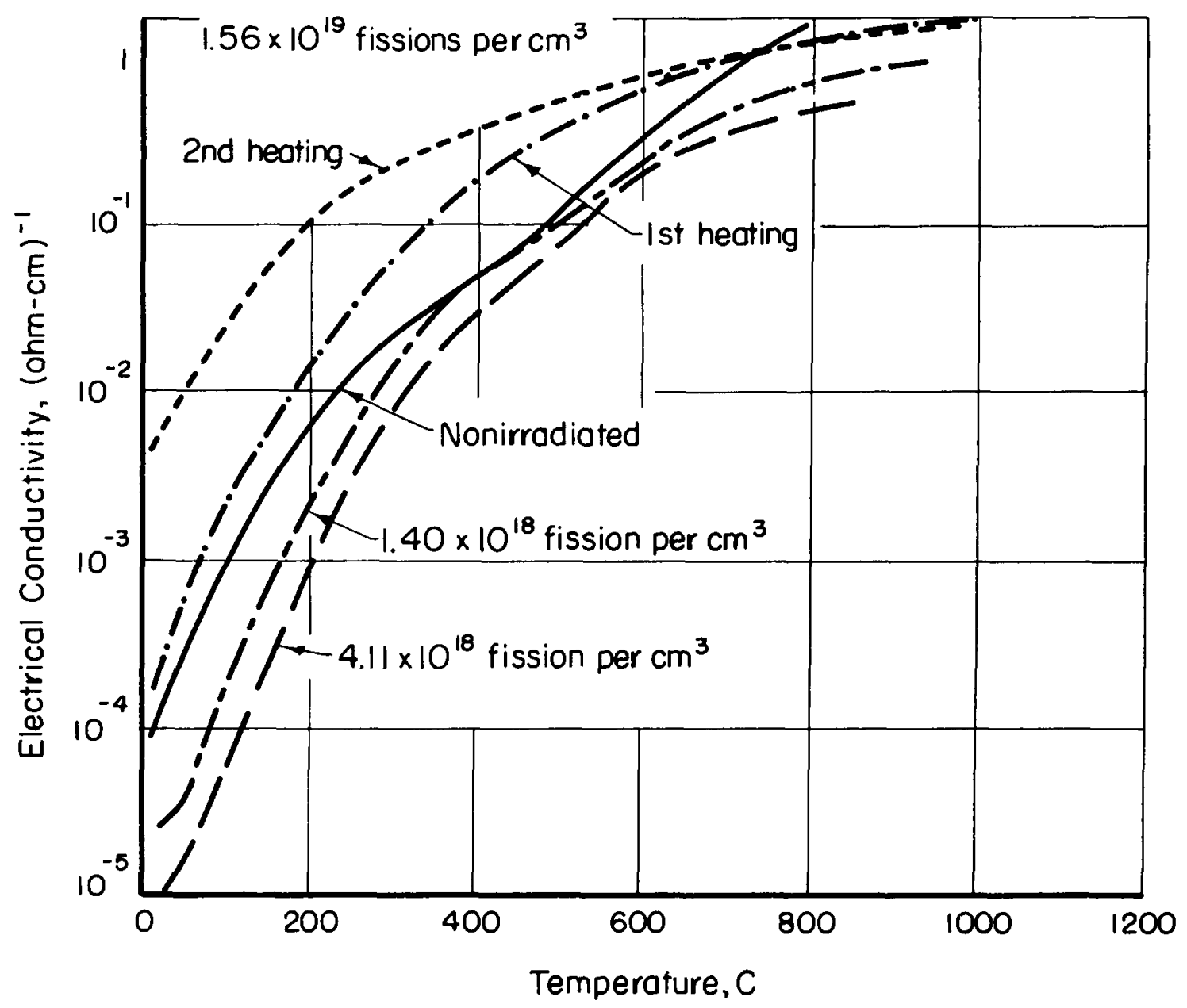

FIGURE G5d. ELECTRICAL CONDUCTIVITY OF POLYCRYSTALLINE $\mathrm{UO}_{2}{ }^{(18)}$ 
(1) Belle, J. , Editor, Uranium Dioxide: Properties and Nuclear Applications, Naval Reactors, Division of Reactor Development, USAEC (July, 1961).

(2) Anderson, J. S., Harper, E. A. , Moorbath, S. , and Roberts, L. E. J., "The Properties and Microstructure of Uranium Dioxide; Their Dependence on the Mode of Preparation", AERE C/R 886 (August 19, 1952).

(3) Katz, J. J., and Rabinowitch, E., The Chemistry of Uranium, National Nuclear Energy Series, Div. VIII, Vol. 5, McGraw-Hill Book Company, New York (1951).

(4) Johnson, J. R., Fulkerson, S. D. , and Taylor, A. J., "Technology of Uranium Dioxide, A Reactor Material", Am. Ceram. Soc. Bull., 36, $12(1957)$.

(5) Johnson, J. R., "Uranium Dioxide", Progress in Nuclear Energy, Series V, Metallurgy and Fuels, Vol. 2, Howe, J. P., and Finnister, H. M. , Editors, Pergamon Press, New York (1950), pp 209-222.

(6) Johnson, J. R., and Curtis, C. E., "The Technology of $\mathrm{UO}_{2}$ and $\mathrm{ThO}_{2}$ ", Proceedings of the International Conference on the Peaceful Uses of Atomic Energy, New York (1956), Vol. 9, pp 169-173.

(7) Gronvold, F., "High Temperature X-Ray Study of Uranium Oxides in $\mathrm{UO}_{2}-\mathrm{U}_{3} \mathrm{O}_{8}$ Region", J. Inorg. Nuclear Chem., 1, 357-370 (1955).

(8) Loch, L. D. , and Quirk, J. F., "Ceramics", Reactor Handbook, Volume 1, Materials, C. R. Tipton, Jr., Interscience Publishers, Inc., New York (1960).

(9) Lambertson, W. A., and Handwerk, J. H. , "The Fabrications and Physical Properties of Uranium Bodies", ANL-5053 (February, 1956).

(10) Ackerman, R. J., "The High Temperature High-Vacuum Vaporization and Thermodynamic Properties of Uranium Dioxide", ANL-5482 (September 14, 1955).

(11) Wisuzi, L. G., and Pijanowski, S. W., "The Thermal Stability of Uranium Dioxide", KAPL-1902 (November 1, 1959).

(12) Ackerman, R. J., Gilles, P. W. , and Thom, R. J., "High Temperature Thermodynamic Properties of Uranium Dioxide", J. Chem. Phys., 25, 1089-1097 (1956).

(13) Ackerman, R. J., Thom, R. J., Alexander, C. A., and Tetenbaum, M., "Free Energies of Formation of Gaseous Molybdenum, Tungsten and Uranium Trioxide", Presented at the Am. Chem. Soc. Meeting, April, 1959. 
(14) Vaughan, D. A., Bridge, J. R., and Schwartz, C. M., "Comparison of Active and Inactive Uranium Dioxide-Oxygen Systems", BMI-1241 (December 10, 1957).

(15) Kempter, C. P., and Elliott, R. O., "Thermal Expansion of UN, $\mathrm{UO}_{2}, \mathrm{UO}_{2}-\mathrm{ThO}_{2}$ and $\mathrm{ThO}_{2}$, J. Chem. Phys., 30, 1524-1526 (1959).

(16) MacEwan, J. R. , "Grain Growth in Sintered Uranium Dioxide", AECL-1184 (January, 1961).

(17) Burdick, M. D., and Parker, H. S., "Effect of Particle Size on Bulk Density and Strength Properties of Uranium Dioxide Specimens", J. Am. Ceram. Soc., 39, 181-187 (1956).

(18) Roake, W. E. , "Irradiation Alteration of Uranium Dioxide", HW-73072 (March, 1962).

(19) Knudsen, F. P., Parker, H. S., and Burdick, M. D., "Flexural Strength of Specimens Prepared From Several Uranium Dioxide Powders; Its Dependence on Porosity and Grain Size and the Influence of Additions of Titania", J. Am. Ceram. Soc., 43, 641-647 (1960).

(20) Armstrong, W. M., and Irvine, W. R., "The Plastic Deformation of Uranium Dioxide at Elevated Temperatures", 63rd Annual Convention of the American Ceramic Society, Toronto, Ontario, Canada, 1961.

(21) Lang, S. M., "Properties of High Temperature Ceramics and Cermets, Elasticity and Density at Room Temperatures", Nat. Bur. Standards (U. S.) Monograph 6 (March 1, 1960).

(22) Scott, R., Hall, A. R., and William, J., "The Plastic Deformation of Uranium Oxides Above 800 C'", J. Nuclear Materials, 1, 39-48 (1959).

(23) Hausner, H. H., and Mills, R. G., "Uranium Dioxide for Fuel Elements", Nucleonics, 15 (7), 94-103 (1957).

(24) Ross, A. M., "The Dependence of Thermal Conductivity of Uranium Dioxide on Density Microstructure, Stoichiometry, and The rmal Neutron Irradiation", CRFD-817 (September, 1960).

(25) Reiswig, R. D., "Thermal Conductivity of $\mathrm{UO}_{2}$ to $2100 \mathrm{C}$ ", J. Am. Ceram. Soc., 44 (1), 48-49 (1961).

(26) Scott, R., "Thermal Conductivity of $\mathrm{UO}_{2}$ ", AERE M/R-2526 (March, 1958).

(27) Kingery, W. D. , Francl, J., Coble, R. L., and Vasilos, T. , "Thermal Conductivity: X, Data For Several Pure Oxide Materials Corrected to Zero Porosity, J. Am. Ceram. Soc., 37, 107-110 (1954). 
(28) Weeks, J., and Seifert, R., "Apparatus for the Measurement of the Thermal Conductivity of Solids", ANL-4938 (1952).

(29) Hedge, J. C. , and Fieldhouse, I. B., "Measurement of Thermal Conductivity of Uranium Oxide", AECU-3881 (September 20, 1956).

(30) Roake, W. E. , "Irradiation Alteration of Uranium Dioxide", HW-73072 (March, 1962).

(31) Robertson, J. A. L., "High Temperature Properties of Ceramic Fuels: Their Significance and Measurement", AECL-1529 (June, 1962).

(32) Matolich, J., Jr., and Deem, H. W., BMI, Unpublished Data.

(33) Kingery, W. D., "Thermal Conductivity: XIV, Conductivity of Multicomponent Systems", J. Am. Ceram. Soc., 42, 617-627 (1959).

(34) Nichols, R. W., "Ceramic Fuels - Properties and Technology", Nuclear Eng., 3 , 327-333 (1958).

(35) Anderson, J. S., Sawyer, J. O., Worner, H. W., Willis, G. M., and Bannister, M. J., "Decomposition of Uranium Dioxide at its Melting Point", Nature, 185, 915-916 (1960).

(36) Power Reactor Technology, 3 (2), 49-50 (March, 1960).

(37) Anderson, J. S., and Sawyer, J. O., "The Stability of Uranium Dioxide in Hydrogen at High Temperature", Proc. Chem. Soc., $145-146$ (1960).

(38) Dickerson, R. F., "Reactor Materials Properties", Nucleonics, 18 (11), 154-161 (1960).

(39) "Metallurgy Division Annual Progress Report for Period Ending September 1, 1959", ORNL-2839 (December 16, 1959).

(40) Barney, W. K., and Wemple, B. D., "Metallograph of $\mathrm{UO}_{2}$ Containing Fuel Elements", KAPL-1836 (January 15, 1958).

(41) Barney, W. K. , "Irradiation Effects in $\mathrm{UO}_{2}$ ", Proceedings of the Second United Nations International Conference on the Peaceful Uses of Atomic Energy, Geneva (1958), Vol. 6, pp 677-680.

(42) Bleiberg, M. L., Yeniscavich, W., and Gray, R. G. , "Effects of Burnup on Certain Ceramic Fuel Materials", Radiation Effects In Refractory Fuel Compounds, ASTM, S. T.P. No. 306 (March 1962), p 64.

(43) Long, G., Davies, D., and Findley, J. R., "Diffusion of Fission Products in Uranium Dioxide and Uranium Monocarbide", Paper presented at The First Conference in Nuclear Reactor Chemistry, Gatlinburg (October 12-14, 1960). 
(44) Booth, A. H., and Rymer, G. T., "Determination of the Diffusion Constant of Fission Xenon in $\mathrm{UO}_{2}$ Crystals and Sintered Compacts", CRDC-720 (August, 1958).

(45) Barnes, R. H. , Kangilaski, M., Melehan, J. B., and Rough, F., "Xenon Diffusion in Single-Crystal and Sintered UO2", BMI-1533 (August 1, 1961).

(46) Stevens, W. B., MacEwan, J. R., and Ross, A. M., "The Diffusion Behavior of Fission Xenon in Uranium Dioxide", Paper presented at The First Conference on Nuclear Reactor Chemistry, Gatlinburg (October 12-14, 1960).

(47) Toner, D. F., and Scott, J. L., "Study of Factors Controlling the Release of Xenon-133 from Bulk $\mathrm{UO}_{2}$ ", Radiation Effects in Refractory Fuel Compounds, ASTM, S. T.P. No. 306 (March, 1962), p 86.

(48) Melehan, J. B., and Rough, F. A., Unpublished Data (August, 1962).

(49) Lewis, W. B., "Behavior of Fission Gases in $\mathrm{UO}_{2}$ Fuel", DL-45 (November, 1961).

(50) Cottrell, W. B., Culver, H. N., Scott, J. L., and Yarosh, M. M., "Fission Product Release From UO 2 ", ORNL-2935 (September 13, 1960).

(51) Robertson, J. A. L., "High Temperature Properties of Ceramic Fuels: Their Significance and Measurement", AECL-1529 (June, 1962).

(52) Eichenberg, J. D., "An In-Pile Measurement of the Effective Thermal Conductivity of $\mathrm{UO}_{2} "$ ", WAPD-200 (March 28, 1958).

(53) Christensen, J. A., and Bates, J. L., "High Temperature Microscopy of Irradiated $\mathrm{UO}_{2} "$, paper presented at Am. Cer. Soc. Meeting, Toronto, Ontario, 23-27, April 1961; Abstract in Cer. Bull. , 40, 4 (1961).

(54) Bates, J. L., Christensen, J. A., and Daniel, J. L., "Ir radiation of Uranium Dioxide Single Crystal", paper presented at ANS Meeting, Boston, 17-21 June, 1962; Abstract in Trans. ANS, $\underline{5}$, 1 (1962). 


\section{URANIUM SILICIDE}

Compiled by M. Kangilaski

A1. Chemical composition

$\mathrm{U}_{3} \mathrm{Si}_{2}, 92.7 \mathrm{w} / \mathrm{o}$ uranium, $7.3 \mathrm{w} / \mathrm{o}$ silicon

2. Phase diagram $(1)$

See Figure A2.

3. Effect of impurities

No data available

B1. Density (room temperature) (2)

$12.20 \mathrm{~g}$ per $\mathrm{cm}^{3}$

2. Density versus temperature

No data available

3. Uranium content

$11.3 \mathrm{~g}$ per $\mathrm{cm}^{3}$

4. Liquidus temperature (1)

$1665 \mathrm{C}$

5. Solidus temperature ${ }^{(1)}$

$1665 \mathrm{C}$

6. Yapor pressure

No data available

7. Thermal expansion (line or) (3)

$14.6 \times 10^{-6}$ per C at 20 to $1000 \mathrm{C}$

8. Recrystallization temperature range No data available

C1. Hardness (room temperature) ${ }^{(4)}$

$659 \mathrm{DPH}$

2. Hot hardness

No data available

3. Ultimate tensile strength

No data available

4. Yield strength

No data available

5. Compressive strength

No data available 


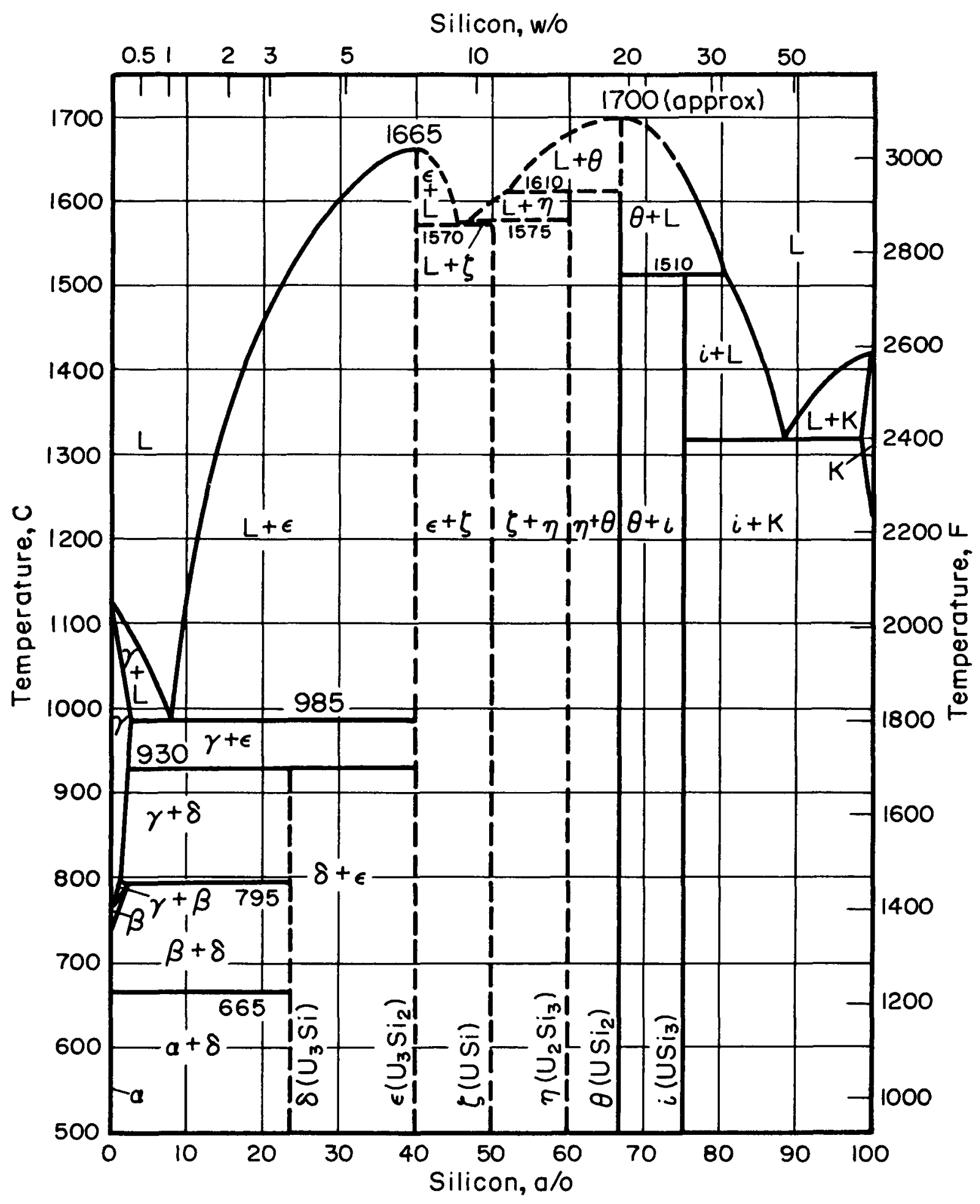

FIGURE A2. URANIUM-SILICON PHASE DIAGRAM ${ }^{(1)}$ 
6. Creep strength

No data arailable

7. Young's modulus $(5)$

$$
7.5 \times 10^{6} \mathrm{psi}
$$

8. Shear modulus

No data arailable

9. Bulk modulus

No data available

10. Poisson's ratio

No data arailable

11. Elongation

No data available

D1. Specific heat ${ }^{(6)}$

$0.0416 \mathrm{cal} /$ (mole)(C), (calculated value)

2. Thermal conductivity $(7)$

$0.035 \mathrm{cal} /(\mathrm{sec})(\mathrm{cm})(\mathrm{C})$ at room temperature

E1. Electrical resistivity ${ }^{(6)}$

$112 \mathrm{microhm}-\mathrm{cm}$ at $100 \mathrm{C} ; 124 \mathrm{microhm}-\mathrm{cm}$ at $300 \mathrm{C}$

Fl. Reactions with coolants

a. Steam

No data available

b. Helium

No data available

c. Carbon dioxide(7)

Similar to uranium

d. Nitrogen $(8)$

Reaction slower than with oxygen, initially parabolic, faster than uranium-nitrogen reaction

e. Hydrogen (7)

Probably incompatible

f. Liquid metals (7)

No attack by NaK after 1 week at $800 \mathrm{C}$; no other data available

g. Air

No data available

2. Reactions with claddings or structural materials

No data available 
G1. Dimensional stability during irradiation ${ }^{(9)}$

A decrease of 6 to 7 per cent in density after burnup of $1.8 \times 10^{20}$ fissions per $\mathrm{cm}^{3}$ at a surface temperature of $690 \mathrm{C}$ and a center temperature of $910 \mathrm{C}$ has been observed.

2. Fission-gas-release data $(9)$

2. 5 per cent of the fission gases were released under the above conditions.

3. Swelling-temperature data

No data available

4. Unusual nuclear properties

No data available

5. Property changes as a result of irradiation

No data available

H. References

(1) Kaufmann, A. R., Cullity, B. D. , Bitsianes, G. , "Uranium Silicon Alloys", J. Metals, 9, 23-27 (January 1957).

(2) Rough, F. A., and Bauer, A. A., "Constitution of Uranium and Thorium Alloys", BMI-1300 (June 2, 1958).

(3) Loch, L. D., Engle, G. B., Snyder, M. J., and Duckworth, W. H. , "Survey of Refractory Uranium Compounds", BMI-1124 (1956).

(4) Unpublished information from AI.

(5) "Annual Technical Progress Report, AEC Unclassified Programs, Fiscal Year 1960", NAA-SR-5350.

(6) Cape, J. A., and Taylor, R. E., "Thermal Properties of Refractory Materials, Quarterly Progress Report No. 3, February 1, 1961 to April 31, 1961", AI-6358.

(7) Nichols, R. W. , "Ceramic Fuels, Properties, and Technology", Nuclear Eng., 3 , 29, 1958.

(8) Snyder, M. J., and Duckworth, W. H. , "Properties of Some Refractory Uranium Compounds", BMI-1223 (September 9, 1957).

(9) Kangilaski, M., BMI, Unpublished Data. 


\section{$\mathrm{UO}_{2}-\mathrm{Al}_{2} \mathrm{O}_{3}$ DISPERSIONS}

Compiled by R. A. Wullaert

A1. Chemical composition

See Figure A2, phase diagram.

2. Phase diagram $(1)$

See Figure A2.

A eutectic occurs at $1900 \pm 10 \mathrm{C}, 48.3 \mathrm{w} / 0 \mathrm{UO}_{2}-51.7 \mathrm{w} / \mathrm{o} \mathrm{Al}_{2} \mathrm{O}_{3}$.

3. Effect of impurities $(2,3)$

Impurities (potassium, sodium) cause fuel migration during sintering. (2)

Additions of $\mathrm{MgO}$ and $\mathrm{SiO}_{2}$ allow fabrication of pellets with higher densities. (3)

B1. Density (room temperature)

Theoretical density of $\mathrm{UO}_{2}-\mathrm{Al}_{2} \mathrm{O}_{3}$ dispersions $=\left(\mathrm{w} / 0 \mathrm{UO}_{2}\right)(10.97)+$ $\left(\mathrm{w} / \mathrm{\circ} \mathrm{Al}_{2} \mathrm{O}_{3}\right)(4.00)$.

2. Density versus temperature

No data available

3. Uranium content

The $\mathrm{UO}_{2}$ fuel particles contain $88 \mathrm{w} / \mathrm{o}$ uranium.

4. Liquidus temperature

See Figure A2.

5. Solidus temperature

See Figure A.2.

6. Vapor pressure

No data available

7. Thermal expansion (linear)

No data available

8. Recrystallization temperature range

No data available

C1. Hardness (room temperature)

No data available

2. Hot hardness

No data available

3. Ultimate tensile strength(4)

The modulus of rupture for a $33 \mathrm{w} / \mathrm{o} \mathrm{UO}_{2}-\mathrm{Al}_{2} \mathrm{O}_{3}$ is in the range of 1900 to 3300 psi (data are for 60 per cent dense material). 

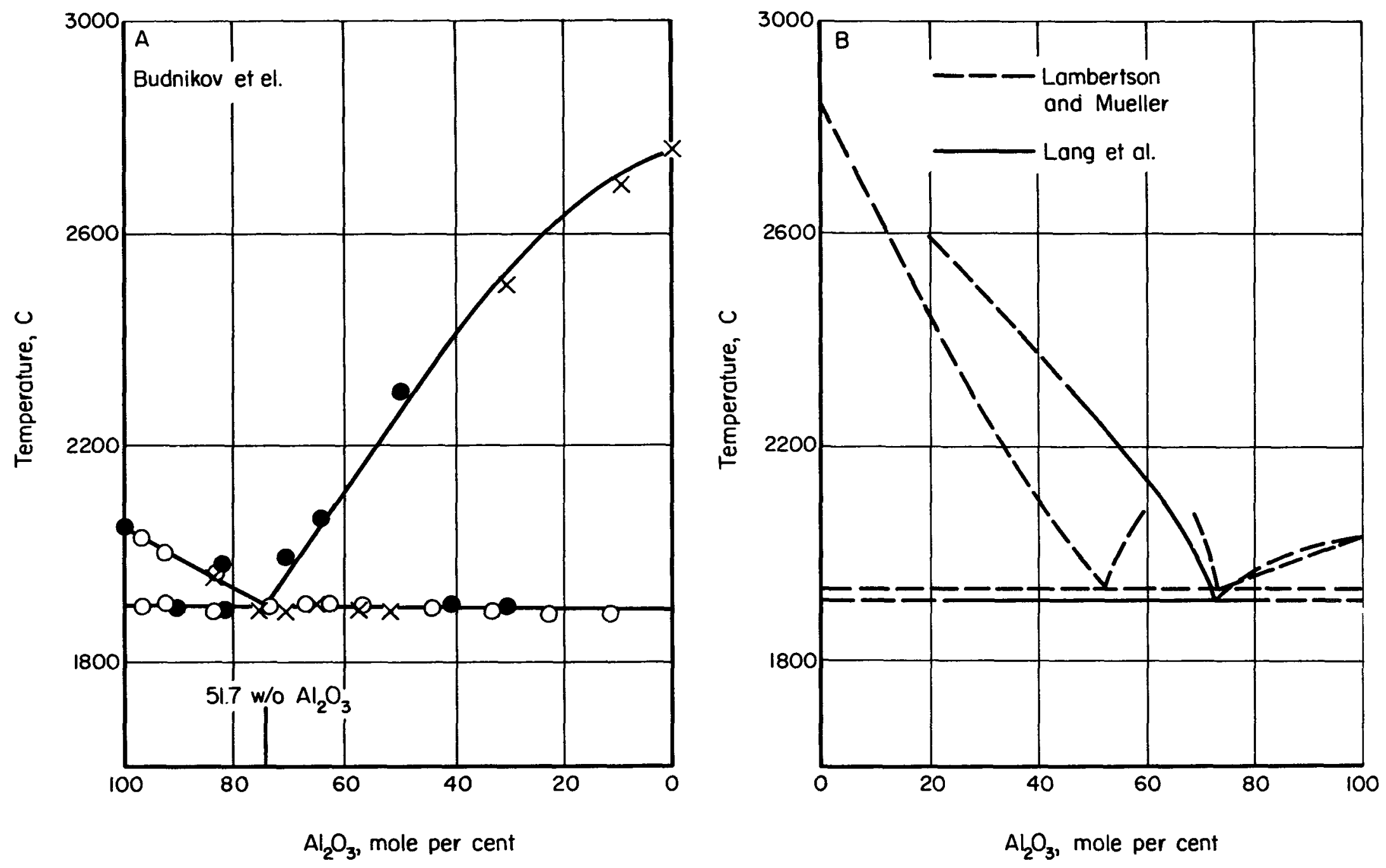

FIGURE A-2 PROPOSED PHASE DIAGRAMS OF THE UO $\mathrm{O}_{2}-\mathrm{Al}_{2} \mathrm{O}_{3}$ SYSTEM $^{(\prime)}$ 
4. Yield strength

No data available

5. Compressive strength

No data available

6. Creep strength

No data available

7. Young's modulus

No data available

8. Shear modulus

No data available

9. Bulk modulus

No data available

10. Poisson's ratio

No data available

11. Elongation

No data available

[1. Specific heat

No data available

2. Thermal conductivity

No data available

E1. Electrical resistivity $(5)$

Electrical resistance is a function of the fuel content and fuel particle size, as shown in Figure El.

F1. Reactions with coolants

a. Steam $(4,6)$

Calcined $\mathrm{Al}_{2} \mathrm{O}_{3}$ is attacked appreciably by water at $650 \mathrm{~F}$, but fused $\mathrm{Al}_{2} \mathrm{O}_{3}$ is comparatively stable (see Table $\mathrm{F}$ la). $\mathrm{Al}_{2} \mathrm{O}_{3}$ exhibits 10 ses of $\sim 1 \mathrm{mg}$ per hr at $1200 \mathrm{C}$ and $3 \mathrm{mg}$ per hr at $1400 \mathrm{C}$ in a gas stream of water vapor. (6)

b. Helium

There is no reaction with $\mathrm{Al}_{2} \mathrm{O}_{3}$.

c. Carbon dioxide(7)

There is no reactivity of $\mathrm{Al}_{2} \mathrm{O}_{3}$ in carbon dioxide in the temperature range of 400 to $800 \mathrm{C}$.

d. Nitrogen

$\mathrm{Al}_{2} \mathrm{O}_{3}$ exhibits losses of $\sim \mathrm{I} \mathrm{mg}$ per hr at $1200 \mathrm{C}$ and $3 \mathrm{mg}$ per hr at $1400 \mathrm{C}$ in a nitrogen gas stream. (6) 


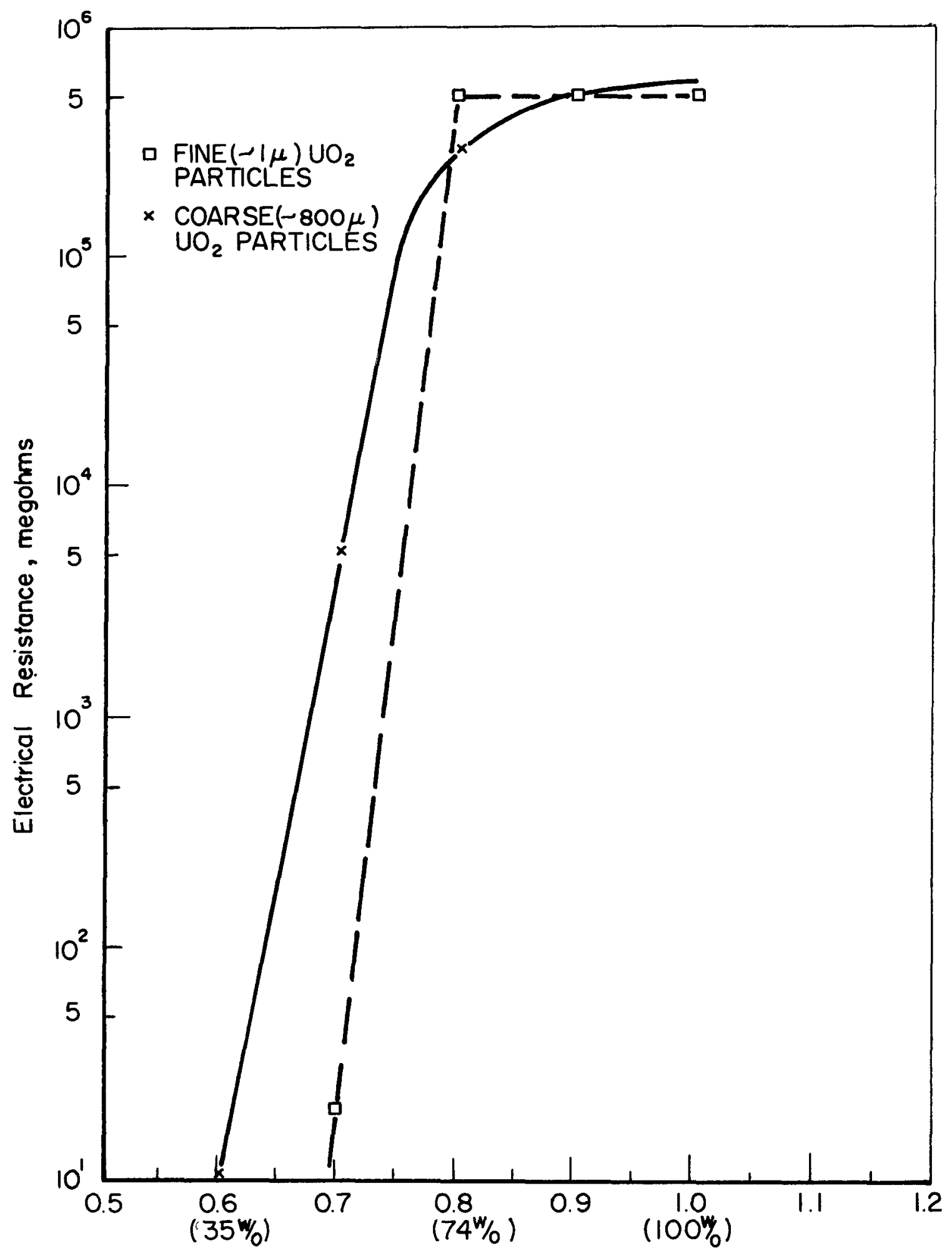

Volume Fraction Occupied by Alumino

FIGURE EI. RELATIONSHIP BETWEEN ELECTRICAL RESISTANCE AND COMPOSITION FOR $\mathrm{Al}_{2} \mathrm{O}_{3}-\mathrm{UO}_{2}$ PELLETS $^{(5)}$ 
TABLE Fla. WATER CORROSION TEST(a) ON $33 \mathrm{w} / \mathrm{o} \mathrm{UO}_{2}-\mathrm{Al}_{2} \mathrm{O}_{3}(4)$

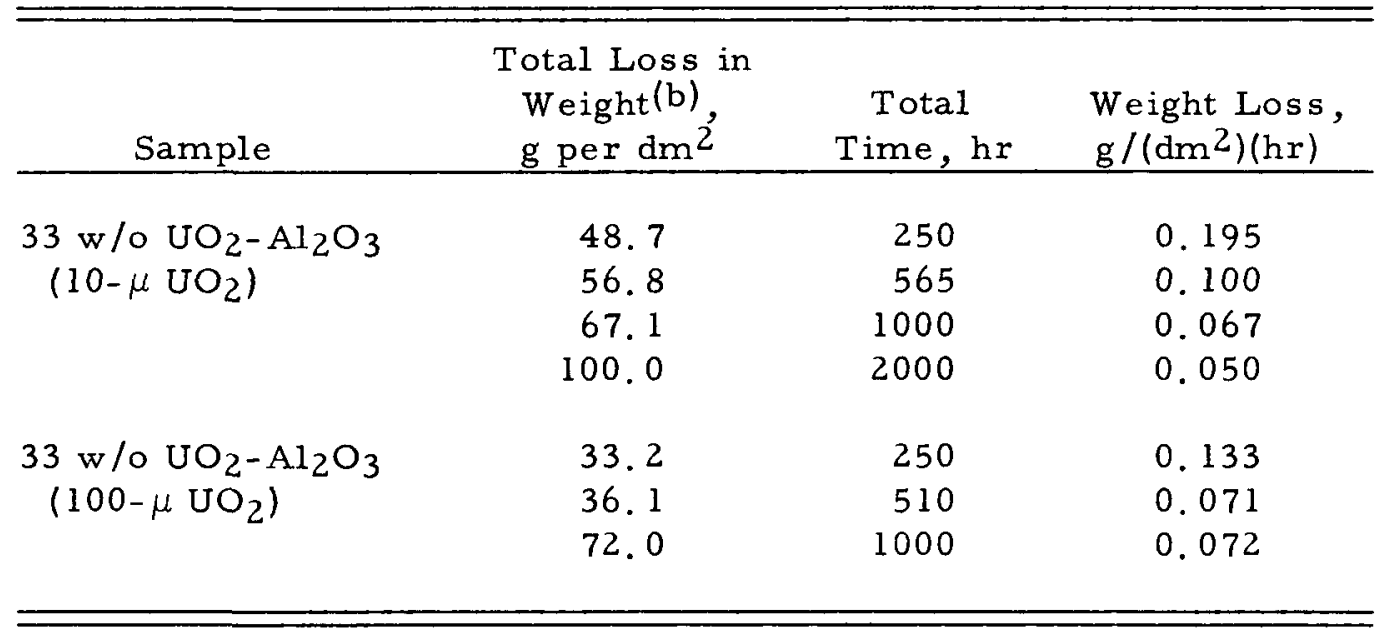

(a) Test performed in static autoclaves with water at $680 \mathrm{~F}$ under $2000 \mathrm{psi}$ and containing LiOH at $\mathrm{pH} 10.0$.

(b) The area is the product of the dimensions and not the true surface area.

e. Hydrogen

There is no reaction with $\mathrm{Al}_{2} \mathrm{O}_{3}$.

f. Liquid metals

No data available

g. Air

There is no reactivity of $\mathrm{Al}_{2} \mathrm{O}_{3}$ in air in the temperature range of 400 to 800 C. (7)

2. Reactions with claddings or structural materials

No data available

G1. Dimensional stability during irradiation $(8-10)$

(See Table G1, Figure G1)

\section{Fission-gas-release}

(See Table G1)

3. Swelling-temperature data

No data available

4. Unusual nuclear properties

No data available

5. Property changes as a result of irradiation

a. Fission fragments appear to produce different and larger effects in $\mathrm{Al}_{2} \mathrm{O}_{3}$, as compared to $\mathrm{UO}_{2}$ and $\mathrm{BeO}$. The fission-fragment damage in $\mathrm{Al}_{2} \mathrm{O}_{3}$ is more like that which occurs in $\mathrm{U}_{3} \mathrm{Si}, \mathrm{U}_{3} \mathrm{O}_{8}$, and $\mathrm{ZrO}_{2} . \mathrm{Al}_{2} \mathrm{O}_{3}$ appears to store large amounts of fission-fragment kinetic energy. (8) 
TABLE G1. DIMENSIONAL STABILITY AND GAS RELEASE OF IRRADIATED UO $\mathrm{O}_{2}-\mathrm{Al}_{2} \mathrm{O}_{3}$

\begin{tabular}{|c|c|c|c|c|c|c|c|c|c|c|}
\hline & & \multicolumn{2}{|c|}{ Estimated Temperature, $\mathrm{C}$} & \multirow{3}{*}{$\begin{array}{c}\text { Burnup, } \\
10^{20} \text { fissions per } \mathrm{cm}^{3}\end{array}$} & \multirow[b]{3}{*}{ a /o U Eiss. } & \multirow{2}{*}{\multicolumn{2}{|c|}{$\begin{array}{c}\text { Physical Change, } \\
\text { per cent }\end{array}$}} & \multirow{3}{*}{$\begin{array}{c}\text { Eission-Gas } \\
\text { Release, } \\
\text { per cent }\end{array}$} & \multirow[b]{3}{*}{ Comment } & \multirow[b]{3}{*}{ Reference } \\
\hline \multicolumn{2}{|c|}{ Composition, w/o } & \multirow{2}{*}{$\begin{array}{l}\text { Fuel } \\
\text { Surface }\end{array}$} & \multirow{2}{*}{$\begin{array}{c}\text { Fuel } \\
\text { Center Line }\end{array}$} & & & & & & & \\
\hline $\mathrm{LO}_{2}$ & $\mathrm{Al}_{2} \mathrm{O}_{3}$ & & & & & Diameter & Density & & & \\
\hline 26 & 74 & 800 & - & 0.45 & $\perp(\mathrm{U}-235)$ & +0.78 & -- & -- & -- & $(10)$ \\
\hline 21 & 79 & 260 & -- & 2.74 & & -- & -18.5 & -- & See Figure $G 1$ & (9) \\
\hline & & 220 & -- & 2.33 & & -- & -19.9 & -- & & \\
\hline & & 110 & - & 1.25 & & -- & -17.9 & - & & \\
\hline & & 390 & -- & 10.8 & & -- & -19.7 & -- & & \\
\hline & & 210 & -- & 6.92 & & -- & -18.8 & -- & & \\
\hline & & 290 & -- & 5.25 & & -- & -17.4 & -- & & \\
\hline & & 300 & -- & 0.92 & & -- & -22.5 & - & & \\
\hline & & 300 & -- & 0.92 & & -- & -16.3 & - & & \\
\hline $\begin{array}{c}80 \\
\text { (depleted) }\end{array}$ & 20 & 40 & -- & 0.002 & & -- & -- & -- & $\begin{array}{l}\text { Loss of } \mathrm{Al}_{2} \mathrm{O}_{3} \\
\text { structure }\end{array}$ & (9) \\
\hline 21 & 79 & 620 & 740 & 4 & 19 & -- & -- & $0.6-1.4 \mathrm{Kr}^{85}$ & In-pile & (8) \\
\hline
\end{tabular}




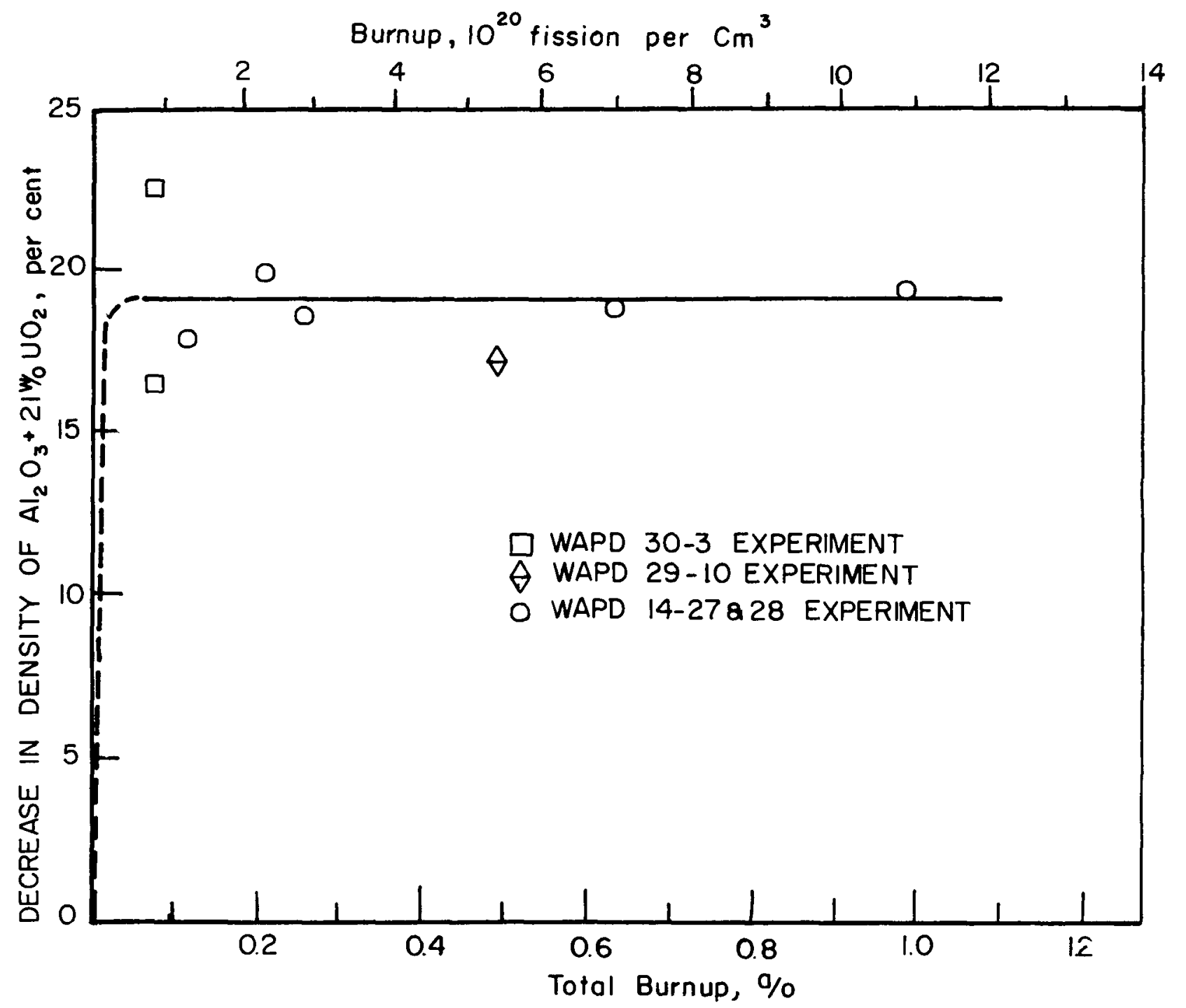

FIGURE GI. INCREASE IN VOLUME OF $21 \% \mathrm{WO}_{2}-\mathrm{Al}_{2} \mathrm{O}_{3}$ ON IRRADIATION 
DISP.

b. Property changes in $21 \mathrm{w} / \mathrm{O} \mathrm{UO}_{2}-\mathrm{Al}_{2} \mathrm{O}_{3}$ (see Table $\mathrm{Gl}$ for irradiation conditions) have been reported. (9) The original porosity in the specimens disappeared, and there were no grain boundaries visible in the $\mathrm{Al}_{2} \mathrm{O}_{3}$ matrix. Collapsed voids appeared in the $\mathrm{UO}_{2}$ particles. The crystal structure of the $\mathrm{Al}_{2} \mathrm{O}_{3}$ was destroyed, but not that of the $\mathrm{UO}_{2}$. The fission-fragment range in the dispersion was sufficient to reach all of the $\mathrm{Al}_{2} \mathrm{O}_{3}$. Annealing for $8 \mathrm{hr}$ at $1000 \mathrm{C}$ in vacuum completely recrystallized the $\mathrm{Al}_{2} \mathrm{O}_{3}$. (9)

H. References

(1) Budnikov, P. P., Tresvyatsky, S. G., and Kushakovsky, V. I., "Binary Phase Diagrams for $\mathrm{UO}_{2}-\mathrm{Al}_{2} \mathrm{O}_{3}, \mathrm{UO}_{2}-\mathrm{BeO}$, and $\mathrm{UO}_{2}-\mathrm{MgO}$ ", Proceedings of the Second United Nations International Conference on the Peaceful Uses of Atomic Energy, Geneva (1958), A/Conf. 15/P/ 2193 , Vol 6, p 125.

(2) "Maritime Gas Cooled Reactor Program, Quarterly Progress Report for Period Ending December 31, 1959", GA-1195.

(3) Livey, D. T., and Murray, P., "The Stability of Beryllia and Magnesia In Different Atmospheres at High Temperatures", J. Nuc. Energy, 2, 202 (1956).

(4) Winsnyi, L. G., and Taylor, K. M., "Fabrication and Evaluation of Urania-Alumina Fuel Elements and Boron Carbide Burnable Poison Elements", ASTM Special Publication No. 276 (1960).

(5) Johnson, D. E., and Tobin, J. M., "Proceedings of the Beryllium Oxide Meeting Held at Oak Ridge National Laboratory, Oak Ridge, Tennessee, December 1-2, 1960", TID-7602 (Pt 1), (1960).

(6) Wickert, K., "Deposits on Heating Surfaces in Steam Generators, II", Brennstoff-Wärme-Kraft, 16, 101 (1958).

(7) Berleman, M. G., and Simon, S. L., "The Volatilization of Beryllia in Water Vapor", ANL 4177 (1948).

(8) Bleiberg, M. L., Yeniscavich, W., and Gray, R. G., "Effect of Burnup on Certain Ceramic Fuel Materials", WAPD-T-1274 (1961).

(9) Berman, R. M., Bleiberg, M. L., and Yeniscavich, W., "Fission Fragment Damage to Crystal Structures", WAPD-T-1125 (February 2, 1960).

(10) Johnson, D. E., and Tobin, J. M., Nuclear Reactor Chemistry, First Conference, Gatlinburg, Tennessee, October 12-14, 1960, TID-7610. 
A1. Chemical composition

$\mathrm{UO}_{2}-\mathrm{BeO}$ dispersions containing from $2 \mathrm{w} / 0 \mathrm{UO}_{2}$ to $80 \mathrm{w} / \mathrm{o} \mathrm{UO}_{2}$ have been successfully fabricated and irradiated.

2. Phase diagram

A eutectic occurs at $2170 \pm 20 \mathrm{C}, 83.6 \mathrm{w} / \mathrm{O} \mathrm{UO}_{2}-16.4 \mathrm{w} / \mathrm{O} \mathrm{BeO}$. (1)

See Figure A2.

3. Effect of impurities

Variations of impurities and fuel-particle size will produce variable sintering characreristics. (2) Carbon in $\mathrm{BeO}$ is responsible for gas-bubble formation along grain boundaries during heat treatment. (3)

B1. Density (room temperature)

Theoretical density of $\mathrm{UO}_{2}-\mathrm{BeO}$ dispersion $=\left(\mathrm{w} / \mathrm{o} \mathrm{UO}_{2}\right)(10.97)+(\mathrm{w} / \mathrm{o} \mathrm{BeO})$ (3.03).

2. Density versus temperature

No data available

3. Uranium content

The $\mathrm{UO}_{2}$ fuel particles contain $68 \mathrm{w} / \mathrm{o}$ uranium.

4. Liquidus temperature

No data available

5. Solidus temperature

No data available

6. Vapor pressure

No data available

7. Thermal expansion $(4)$

$70.9 \mathrm{w} / \mathrm{O} \mathrm{UO}_{2}-29.1 \mathrm{w} / \mathrm{o} \mathrm{BeO}$ has a coefficient of thermal expansion of

$8.84 \times 10^{-6}$ per $\mathrm{C}$ for the temperature range between 100 and $400 \mathrm{C}$

8. Recrystallization temperature range $(5,6)$

Grain growth of both components of $\mathrm{UO}_{2}-\mathrm{BeO}$ dispersions has been reported to occur above $1600 \mathrm{C}$. There is marked recrystallization of $\mathrm{BeO}$ above 2050 C. (7)

\section{Cl. Hardness (room temperature) \\ No data available}

2. Hot hardness

No data available 

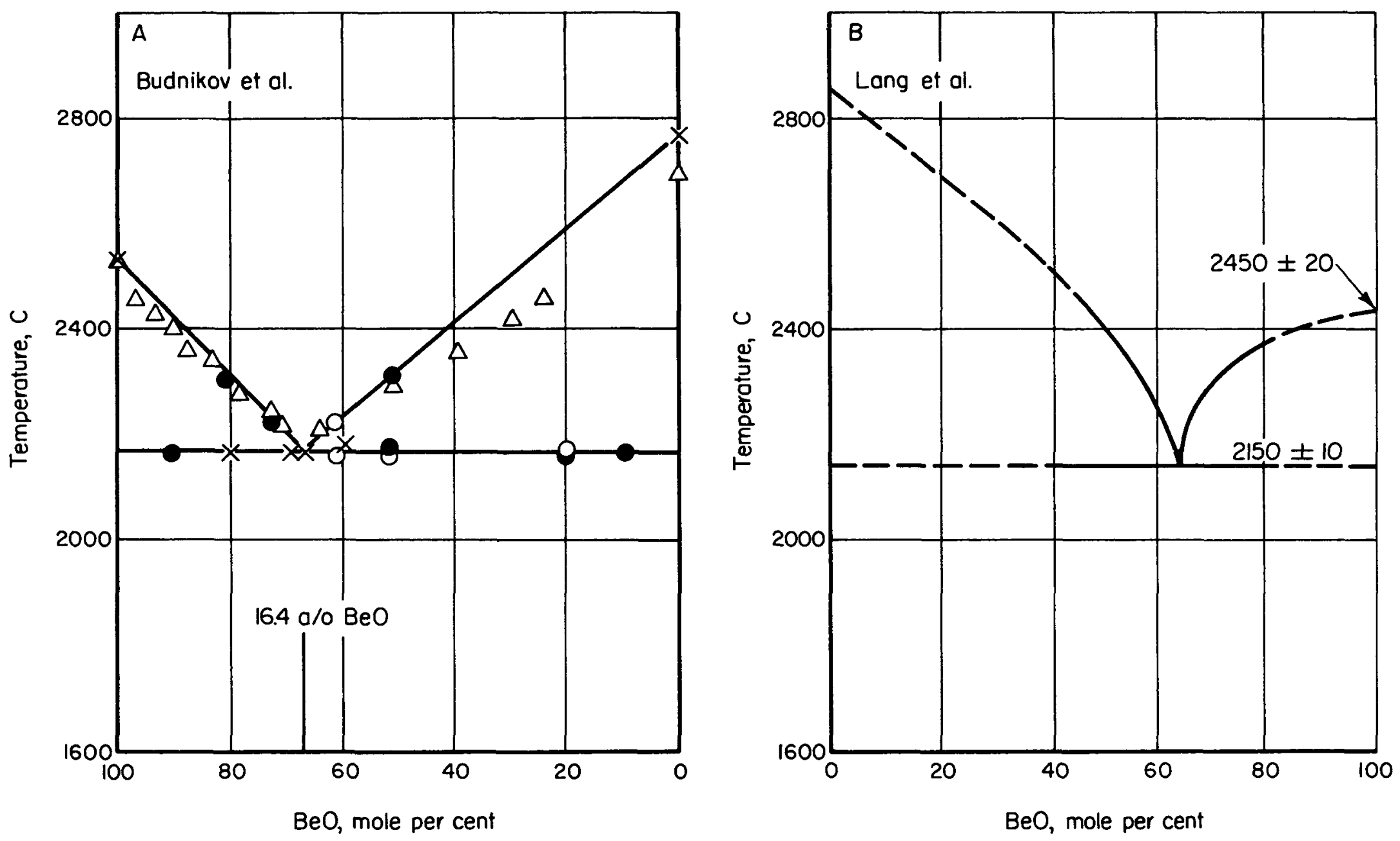

FIGURE A-2 PROPOSED PHASE DIAGRAMS OF THE $\mathrm{UO}_{2}-\mathrm{BeO}$ SYSTEM ${ }^{\prime \prime}$ 
3. Ultimate tensile strength ${ }^{(8)}$

$\begin{array}{rcc}\text { Composition } & \begin{array}{c}\text { Bending Strength, } \\ \text { psi }\end{array} & \begin{array}{c}\text { Density, per cent } \\ \text { of theoretical }\end{array} \\ 2 \mathrm{w} / \circ \mathrm{UO}_{2}-\mathrm{BeO} & 27,600 & 98 \\ 10 \mathrm{w} / \circ \mathrm{UO}_{2}-\mathrm{BeO} & 32,800 & 98\end{array}$

4. Yield strength

No data available

5. Compressive strength

Crushing strength of $48.3 \mathrm{w} / 0 \mathrm{UO}_{2}-\mathrm{BeO}$ is $83,300 \pm 8,000$ psi. $(9,10)$ Compressive strength is sensitive to the density and fuel content, as shown in Table C5. (11)

TABLE C5. SOME PROPERTIES OF HOT-PRESSED BeO AND $\mathrm{BeO}-10 \mathrm{w} / 0 \mathrm{UO}_{2}$ COMPACTS(11)

\begin{tabular}{|c|c|c|c|c|}
\hline Material & $\begin{array}{l}\text { Density, } \\
\mathrm{g} \operatorname{per} \mathrm{cm}^{3}\end{array}$ & $\begin{array}{l}\text { Elastic Modulus, } \\
10^{10} \text { dynes per } \mathrm{cm}^{2}\end{array}$ & $\begin{array}{c}\text { Compressive } \\
\text { Strength, } \\
10^{3} \mathrm{psi}\end{array}$ & $\begin{array}{c}\text { Thermal } \\
\text { Conductivity }(25 \mathrm{C}) \\
\text { cal } /(\mathrm{cm})(\mathrm{sec})(\mathrm{C})\end{array}$ \\
\hline B eo & $\begin{array}{l}2.7 \\
2.9\end{array}$ & $\begin{array}{l}270 \\
350\end{array}$ & $\begin{array}{l}125 \\
175\end{array}$ & $\begin{array}{l}0.25 \\
0.25\end{array}$ \\
\hline $\mathrm{BeO}-10 \mathrm{w} / \mathrm{O} \mathrm{UO}_{2}$ & $\begin{array}{l}2.9 \\
3.0\end{array}$ & $\begin{array}{l}305 \\
340\end{array}$ & $\begin{array}{l}155 \\
188\end{array}$ & $\begin{array}{l}0.20-0.25 \\
0.20-0.25\end{array}$ \\
\hline
\end{tabular}

6. Creep strength

No data available

7. Young's modulus

Young's modulus is sensitive to the density and fuel content of the dispersion (see Table C5). (11)

8. Shear modulus

No data available

9. Bulk modulus

No data available

10. Poisson's ratio

No data available

11. Elongation

No data available

D1. Specific heat

No data available 
$\mathrm{UO}_{2}-\mathrm{BeO}$

DISP.

\section{Thermal conductivity}

Greater than 35 volume per cent $\mathrm{UO}_{2}(66 \mathrm{w} / \mathrm{o})$ results in a great loss in the thermal conductivity. (12) Thermal conductivity is sensitive to the density and fuel content as shown in Table $\mathrm{C5}^{(11)}$ and Figures D2a and D2b(13).

\section{E1. Electrical resistivity}

No data available

\section{F1. Reactions with coolants}

a. Steam

Beryllia reacts with water vapor to form a volatile compound believed to be beryllium hydroxide. The rate-controlling process is the diffusion of the gaseous beryllium hydroxide through the laminar boundary layer produced at the BeO surface by the flowing gases. (14) The results of various investigators for the corrosion of $\mathrm{BeO}$ in moist air are given in Table Fla(1). (13, 15, 16) For similar experimental conditions, there appears to be some divergence of results. The reaction in moist air is strongly influenced by surface phenomena, (17) which may account for the variations in results. The corrosion of $\mathrm{BeO}$ as a function of exposure temperature is illustrated in Tables Fla(2) and Fla(3). (16, i7) Sintered BeO suffers no apparent attack by humid air (water content - 23. $1 \mathrm{mg}$ per liter) after exposures of up to $250 \mathrm{hr}$ at $1100 \mathrm{C.}$ (17) At temperatures above this, the corrosion would become significant under reactor conditions. The data indicate that moist air will not cause excessive corrosion of sintered $\mathrm{BeO}$, but the effects of higher gas velocities and radiation on the process have not been taken into account. Additions of $\mathrm{Al}_{2} \mathrm{O}_{3}$ to $\mathrm{BeO}$ have not reduced the volatility of $\mathrm{BeO}$ sufficiently to decrease the corrosion rates. (18)

b. Helium

Structural failure and color changes occur in $\mathrm{BeO}$ when it is heated to $2100 \mathrm{C}$ in helium. See Table Flb. (19)

c. Carbon dioxide

No data available

d. Nitrogen

There is no reaction with $\mathrm{BeO}$.

e. Hydrogen

The presence of hydrogen induced a reaction between $\mathrm{BeO}$ and carbon at 1600 C. See Table Flb. (19)

f. Liquid metals

No data available

g. Air

There is no reaction of dry air with $\mathrm{BeO}$ below $2000 \mathrm{C}$ ( $^{(7)}$

\section{Reactions with claddings or structural materials}

56-59 w/o $\mathrm{UO}_{2}-\mathrm{BeO}$ : There was no reaction with Hastelloy $\mathrm{X}$ or Type 316 stainless steel after irradiation at temperatures up to 940 C. (20) 


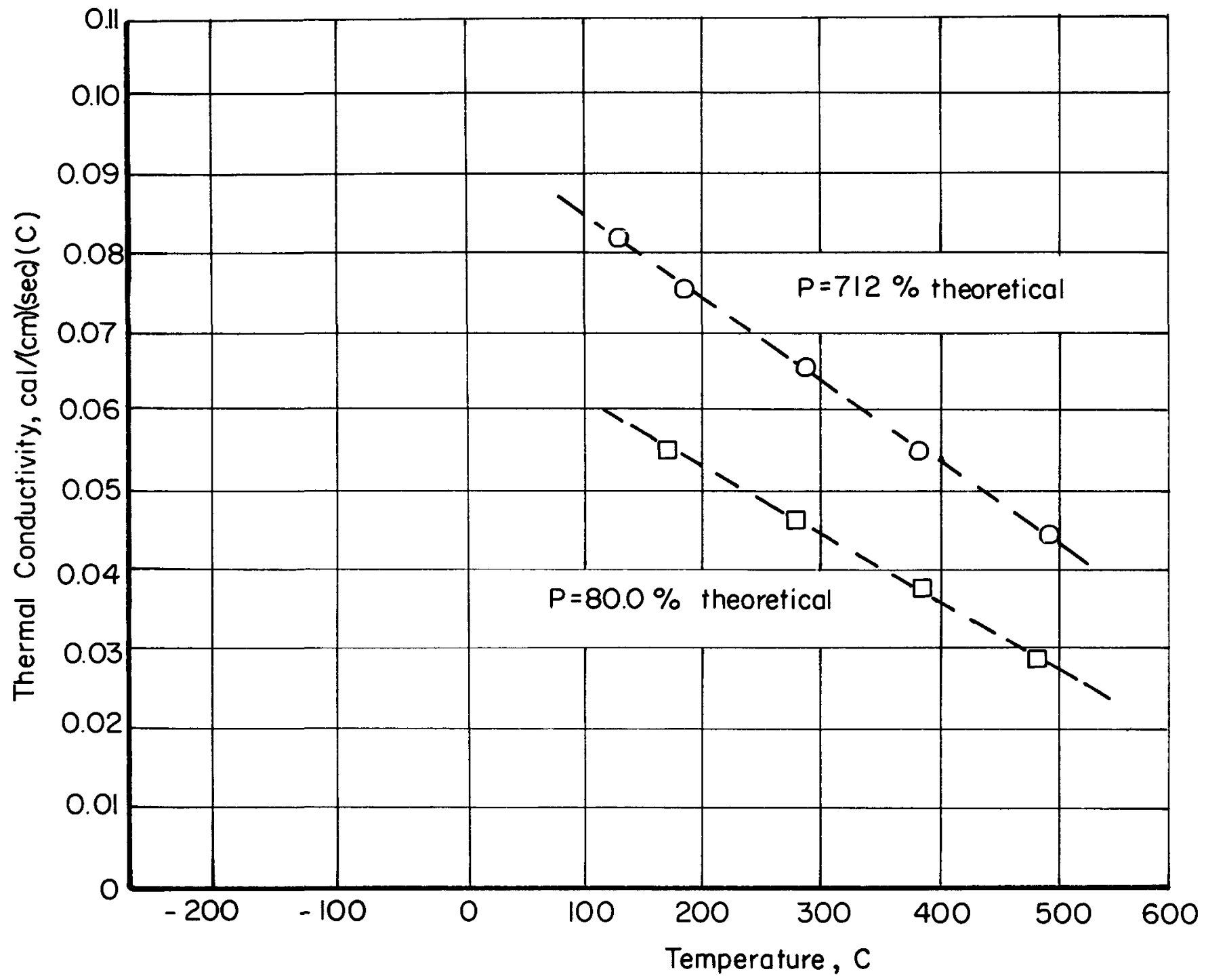

FIGURED20. Thermal Conductivity of $47 \mathrm{w} / \mathrm{0} \mathrm{UO}_{2} \mathrm{BeO}^{(13)}$ 


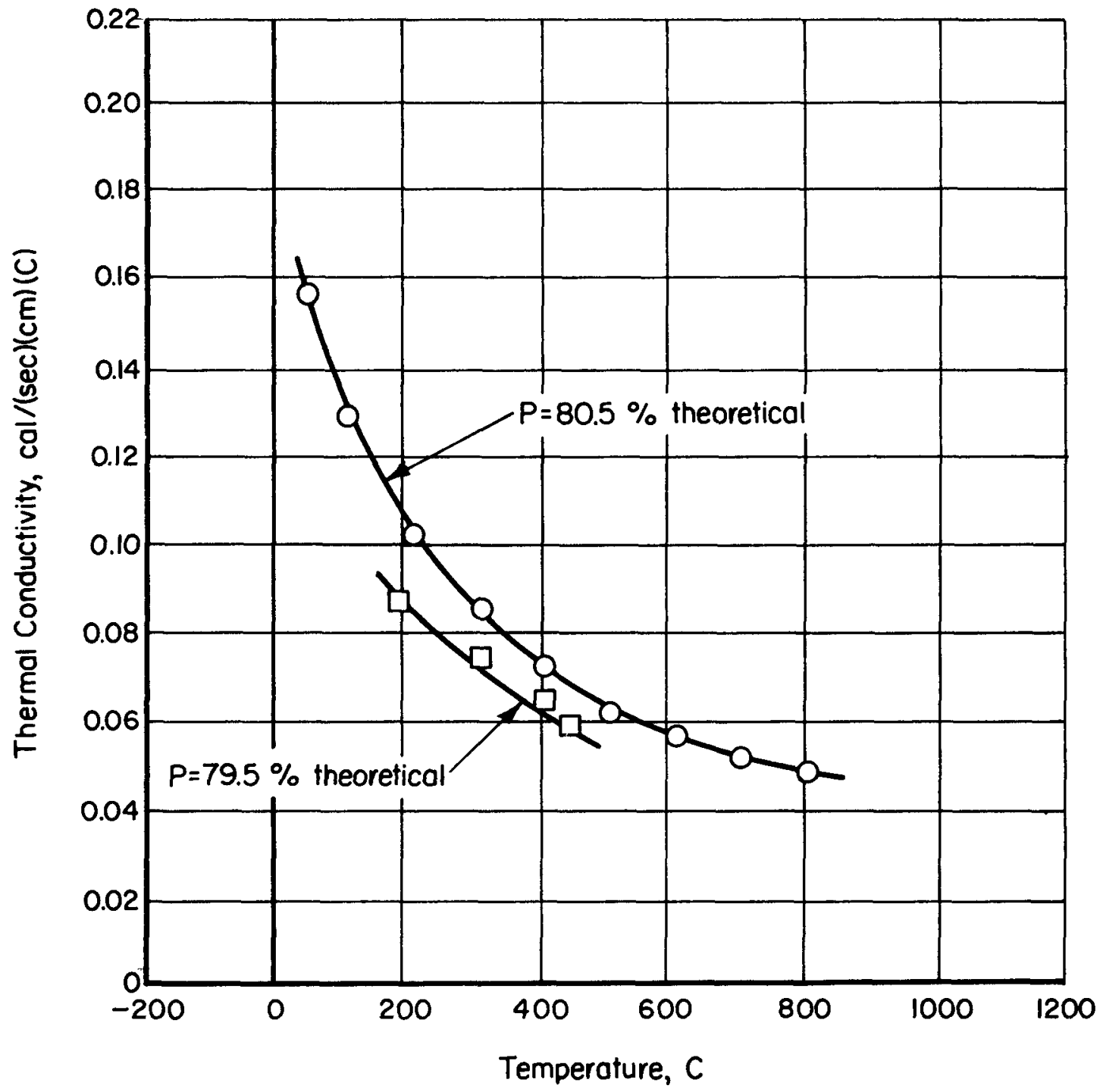

FIGURE D2B. THERMAL CONDUCTIVITY OF $70.9 \mathrm{w} / \mathrm{O} \mathrm{UO}_{2}-\mathrm{BeO}^{(13)}$ 
TABLE Fla(1). THE CORROSION OF BeO IN MOIST AIR(a)

\begin{tabular}{ccccc}
\hline $\begin{array}{c}\text { Temperature, } \\
\text { C }\end{array}$ & $\begin{array}{c}\text { Gas Velocity, } \\
\text { m per hr }\end{array}$ & $\begin{array}{c}\text { Weight Loss, } \\
\mathrm{mg} /\left(\mathrm{cm}^{2}\right)(\mathrm{hr})\end{array}$ & $\begin{array}{l}\text { Loss Rate, } \\
\mu \text { per year }\end{array}$ & References \\
\hline 1550 & 994 & 10.2 & $2.2 \times 10^{5}$ & $(15)$ \\
1550 & 994 & 2.6 & $5.8 \times 10^{4}$ & $(16)$ \\
1535 & 3620 & 0.23 & $5.1 \times 10^{3}$ & $(13)$ \\
\hline
\end{tabular}

(a) Experiments were of the standard transpiration type in which moist air saturated at 25 and $50 \mathrm{C}$ (with moisture contents of 23.13 and $93.12 \mathrm{mg}$ per liter of air) was passed over BeO.

TABLE Fla(2). CORROSION OF BeO IN PURE STEAM ${ }^{(16)}$

\begin{tabular}{cc}
\hline $\begin{array}{c}\text { Temperature, } \\
\mathrm{C}\end{array}$ & $\begin{array}{c}\text { Weight Loss, } \\
\mathrm{mg} /\left(\mathrm{cm}^{2}\right)(\mathrm{hr})\end{array}$ \\
\hline 1000 & 0.01 \\
1250 & 0.22 \\
1400 & 0.76 \\
1500 & 1.83 \\
1550 & 2.60 \\
\hline
\end{tabular}


TABLE Fla(3). CORROSION RATES FOR SINTERED BEO IN HUMID AIR ${ }^{(17)}$

\begin{tabular}{|c|c|c|c|c|}
\hline $\begin{array}{c}\text { Air Saturation } \\
\text { Temperature, } \\
\text { C } \\
\end{array}$ & $\begin{array}{c}\text { Sample } \\
\text { Temperature, } \\
\text { C }\end{array}$ & $\begin{array}{c}\text { Geometric } \\
\text { Specific } \\
\text { Gravity }\end{array}$ & $\begin{array}{c}\text { Duration of } \\
\text { Individual } \\
\text { Exposures, } \mathrm{hr}\end{array}$ & $\begin{array}{l}\text { Corrosion } \\
\text { Rate, } \\
\mathrm{g} /\left(\mathrm{cm}^{2}\right)(\mathrm{hr})\end{array}$ \\
\hline 25 & 1100 & $\begin{array}{l}2.97 \\
2.51\end{array}$ & $\begin{array}{l}\text { Var. } \\
\text { Var. }\end{array}$ & $\begin{array}{l}<0.02 \\
<0.02\end{array}$ \\
\hline & 1200 & $\begin{array}{l}2.99 \\
2.60\end{array}$ & $\begin{array}{l}24 \\
24\end{array}$ & $\begin{array}{l}1.0 \\
2.2\end{array}$ \\
\hline & 1300 & $\begin{array}{l}2.69 \\
2.86 \\
2.99 \\
2.98 \\
2.25 \\
2.36\end{array}$ & $\begin{array}{r}24 \\
24 \\
\text { Var. } \\
24 \\
\text { Var. } \\
24\end{array}$ & $\begin{array}{l}2.3 \\
2.4 \\
1.1 \\
2.5 \\
1.4 \\
3.0\end{array}$ \\
\hline 50 & 1300 & $\begin{array}{l}2.27 \\
2.98\end{array}$ & $\begin{array}{l}24 \\
24\end{array}$ & $\begin{array}{r}10.4 \\
6.3\end{array}$ \\
\hline
\end{tabular}

(a) Variable exposures, in integral multiples of $24 \mathrm{hr}$.

TABLE Flb. WEIGHT LOSS OF BeO ${ }^{(a)}$ IN HYDROGEN AND HELIUM AT ELEVATED TEMPERATURES ${ }^{(19)}$

\begin{tabular}{ccc}
\hline \multirow{2}{*}{$\begin{array}{c}\text { Temperature, } \\
\text { C }\end{array}$} & \multicolumn{2}{c}{ Weight Loss, per cent } \\
\cline { 2 - 3 } 1575 & 2 & In Hydrogen \\
1600 & - & -- \\
1900 & 8 & 0.5 \\
2100 & 46 & 2.5 \\
2300 & -- & 8 \\
& & 13 \\
\hline
\end{tabular}

(a) BeO was fabricated by sintering at $1890 \mathrm{C}$ for $30 \mathrm{~min}$ in air. The impurity content was less than 1 per cent. The specimen was mounted on carbon. 
$61 \mathrm{w} / 0 \mathrm{UO}_{2}-\mathrm{BeO}$ : There was no reaction with $\mathrm{ThO}_{2}$ spacers during irradiation at $\sim 1000$ C. $(21)$

\section{G1. Dimensional stability during irradiation $(9,10,12,20-26)$}

See Table Gl.

\section{Fission-gas-release data}

The rate of release of $\mathrm{Xe} \mathrm{e}^{133}$ from neutron-activated samples of $61 \mathrm{w} / \mathrm{o}$ $\mathrm{UO}_{2}-\mathrm{BeO}$ was determined at 1200, 1400, 1600, and $1300 \mathrm{C}$. At 1200 and $1400 \mathrm{C}$, a small initial burst of $\mathrm{Xe} 133$ was observed with subsequent release by a diffusion mechanism. At $1600 \mathrm{C}$, the initial release was much higher, but apparently diffusion controlled. The pellets released nearly all of their fission gas in approximately $30 \mathrm{hr}$ at $1800 \mathrm{C}$, and the re appeared to have been a microstructural change in the BeO matrix. $(5,6)$

\section{Swelling-temperature data}

No data available

\section{Unusual nuclear properties}

$\mathrm{BeO}$ has excellent moderating properties. The slowing-down power $\left(\xi \Sigma_{\mathrm{s}}\right)$ is 0.13 , and the noderating ratio $\left(\frac{\xi \Sigma_{\mathrm{S}}}{\Sigma_{\mathrm{a}}}\right)$ is $180 .{ }^{(7)}$ Helium and tritiurn are produced in BeO mainly by the $(n, 2 n)$ and $(n, \alpha)$ reactions with beryllium. The reactions involved are the following:

a. $(n, 2 n)$ reaction:

$$
\begin{aligned}
& \mathrm{Be}^{9}+\mathrm{n} \rightarrow \mathrm{Be}^{8}+2 \mathrm{n}(\text { threshold energy }=2.7 \mathrm{Mev}), \\
& \left.\mathrm{Be} \mathrm{e}^{8} \rightarrow 2 \mathrm{He}^{4} \text { (half-1ife }=10^{-14} \mathrm{sec}\right)
\end{aligned}
$$

b. (n, a) reaction:

$$
\begin{aligned}
& \left.\mathrm{Be}^{9}+\mathrm{n} \rightarrow \mathrm{He}^{6}+\mathrm{HI}^{4} \text { (threshold energy }=0.7 \mathrm{l} \mathrm{Mev}\right), \\
& \left.\mathrm{He}^{6} \rightarrow \mathrm{Li}^{6}+\beta \text { (half-life }=0.82 \mathrm{sec}\right) \\
& \mathrm{Li}^{6}+\mathrm{n} \rightarrow \mathrm{He}^{4}+\mathrm{H}^{3} \text { (thermal-neutron capture) }
\end{aligned}
$$

\section{Property changes as a result of irradiation}

a. Radiation may accelerate the corrosion rate of $\mathrm{BeO}$ in moist air by introducing hydrogen into the air stream (27) A few investigators $(11,28)$ have reported a radiation-induced reaction between water vapor and carbon contained in $\mathrm{BeO}$. It has been estimated that 3 to $5 \mathrm{w} / \mathrm{o}$ fissionfragment impurity content in $\mathrm{UO}_{2}$ will destroy its lattice, whereas only $2 \mathrm{w} / \mathrm{o}$ is necessary in $\mathrm{BeO}$. This may be due to greater irradiation stability of cubic lattice $\left(\mathrm{UO}_{2}\right)$ over hexagonal (BeO). The threshold value for lattice destruction in $\mathrm{BeO}$ is 11 to $27 \times 10^{20}$ fission fragrnents per $\mathrm{cm}^{3}$, and $\mathrm{UO}_{2}$ loses its crystallinity in the range of 36 to $64 \times 10^{20}$ fission fragments per $\mathrm{cm}^{3}$. The (22) stimates depend on lattice restraint, burnup rate, and temperature. (22) 
TABLE G1. DIMENSIONAL ST ABILITY AND GAS RELEASE OF IRRADIATED UO $2^{-B e O}$

\begin{tabular}{|c|c|c|c|c|c|c|c|c|c|}
\hline \multirow[b]{2}{*}{ Composition } & \multicolumn{2}{|c|}{$\begin{array}{c}\text { Estumated Fuel } \\
\text { Temperature }{ }^{(a)}, \mathrm{C} \\
\end{array}$} & \multicolumn{2}{|c|}{ Burnup } & \multicolumn{2}{|c|}{ Physical Change, per cent } & \multirow{2}{*}{$\begin{array}{c}\text { Fission Gas Released, } \\
\text { per cent }\end{array}$} & \multirow[b]{2}{*}{ Comments } & \multirow[b]{2}{*}{ Reference } \\
\hline & $\mathrm{T}_{s}$ & $\mathrm{~T}_{\mathrm{c}}$ & $10^{20}$ Eissions per $\mathrm{Cm}^{3}$ & Uranıum, d/o & Diameter & Density & & & \\
\hline $25.3 \mathrm{w} / \mathrm{o} \mathrm{UO}_{2}-\mathrm{BeO}$ & 499 & 504 & 11.1 & 54.5 & $+27^{(\mathrm{b})}$ & -- & $19.9\left(\mathrm{Kr}^{85}\right)$ & $25-\mu$-sıe $\mathrm{UO}_{2}$ & $(22)$ \\
\hline $287 \mathrm{w} / \mathrm{o} \mathrm{UO} \mathrm{U}_{2}-\mathrm{BeO}$ & 516 & 521 & 12.1 & 54.3 & $+6^{(b)}$ & -- & $6.9\left(\mathrm{Kr}^{85}\right)$ & $150-\mu$-sıze UO ${ }_{2}$ & (22) \\
\hline $30.1 \mathrm{w} / \mathrm{OUO} 2-\mathrm{BeO}$ & 454 & 460 & 107 & 44.4 & $+8^{(b)}$ & -- & -- & $\begin{array}{l}150-\mu \text {-s1ze } \mathrm{UO}_{2} \\
\mathrm{UO}_{2} \text { leached from } \\
\text { surface of plate }\end{array}$ & (22) \\
\hline $65 \mathrm{w} / \mathrm{o} \mathrm{UO}_{2}-\mathrm{BeO}$ & 682 & 688 & 108 & 14.2 & $+4^{(b)}$ & -- & $0.1\left(\mathrm{Kr}^{85}\right)$ & $25-\mu$-size $\mathrm{UO}_{2}$ & $(22)$ \\
\hline $53.2 \mathrm{w} / \mathrm{o} \mathrm{\textrm {UO } _ { 2 }}-\mathrm{BeO}$ & 840 & -- & -- & 1.5 & -- & Nil & $0.1-0.15\left(\mathrm{Kr}^{85}\right)$ & -- & (J2) \\
\hline $59.2 \mathrm{w} / \mathrm{o} \mathrm{UO} \mathrm{UO}_{2}-\mathrm{BeO}$ & 1250 & -- & 0.7 & -- & Nil & Nil & $0.4\left(\mathrm{Kr}^{85}\right)$ & -- & (23) \\
\hline \multirow[t]{2}{*}{$48.3 \mathrm{w} / \mathrm{o} \mathrm{UO} \mathrm{UO}_{2}-\mathrm{BeO}$} & 1250 & -- & $\sim 2.0$ & -- & N1l & Nil & - & $125-\mu$-size $\mathrm{UO}_{2}$ & $(9,10)$ \\
\hline & & & 5 & -- & -- & -3 & -- & -- & $(9,10)$ \\
\hline $56 \mathrm{w} / \mathrm{o} \mathrm{UO}_{2}-\mathrm{BeO}$ & $780-940$ & $>1000$ & 1.3 & -- & -- & -1.0 to -2.4 & -- & $44-\mu$-s1ze $\mathrm{UO}_{2}$ & $(20,24)$ \\
\hline $59 \mathrm{w} / \mathrm{O} \mathrm{UO}_{2}-\mathrm{BeO}$ & $780-940$ & $>1000$ & 1.3 & -- & -- & -1.0 to -2.4 & -- & $150-\mu$-size UO $_{2}$ & $(20,24)$ \\
\hline \multirow[t]{3}{*}{$58.9 \mathrm{w} / \mathrm{o} \mathrm{UO}_{2}-\mathrm{BeO}$} & -- & $(1010)$ & -- & $\sim 4.2$ & +0.5 to 1.6 & -- & $0.3\left(\mathrm{Kr}^{85}\right)$ & $<5-\mu$-size $\mathrm{UO}_{2}$ & (21) \\
\hline & & (1200) & -- & $\sim 4.2$ & +1.5 to 2.4 & -- & $0.3\left(\mathrm{Kr}^{85}\right)$ & -- & (21) \\
\hline & & $(1090)$ & -- & $\sim 5.1$ & +0.2 to 1.5 & -- & $0.2\left(\mathrm{Kr}^{85}\right)$ & -- & (21) \\
\hline 70 w/o $\mathrm{UO}_{2}-\mathrm{BeO}$ & 930 & 1700 & $5-6.4$ & -- & No change & -- & $0.59-2.7\left(\mathrm{Kr}^{85}\right)$ & -- & (25) \\
\hline $80 \mathrm{w} / \mathrm{o} \mathrm{UO} \mathrm{UO}_{2}-\mathrm{Beo}$ & 930 & 1700 & $5-6.4$ & -- & No change & -- & $0.59-2.7\left(\mathrm{Kr}^{85}\right)$ & -- & (25) \\
\hline \multirow[t]{6}{*}{$2 \mathrm{w} / \mathrm{O} \mathrm{UO}_{2}-\mathrm{BeO}$} & -- & $(250)$ & -- & 0.53 & +0.50 & -- & -- & -- & (11) \\
\hline & & & & & +0.62 & -- & -- & -- & (11) \\
\hline & & & & 1.08 & +0.90 & -- & -- & -- & (11) \\
\hline & & & & & +0.52 & -- & -- & -- & (11) \\
\hline & & & & 1.86 & +0.60 & -- & -- & -- & (11) \\
\hline & & & & & +0.65 & -- & - & -- & (11) \\
\hline \multirow[t]{6}{*}{$10 \mathrm{w} / \mathrm{o} \mathrm{UO} \mathrm{UO}_{2}-\mathrm{BeO}$} & -- & $(650)$ & -- & 0.53 & +0.44 & -- & - & $<2-\mu$-sıze $\mathrm{UO}_{2}$ & (11) \\
\hline & & & & & +0.61 & -- & - & -- & (11) \\
\hline & & & & 1.08 & +0.71 & -- & -- & $<2-\mu$-s1ze $\mathrm{UO}_{2}$ & (11) \\
\hline & & & & & +0.46 & -- & -- & -- & (11) \\
\hline & & & & 1.86 & +0.62 & - & -- & $<2-\mu$-sıze $\mathrm{UO}_{2}$ & (11) \\
\hline & & & & & +0.65 & -- & -- & -- & (11) \\
\hline \multirow[t]{3}{*}{$47.4 \mathrm{w} / \mathrm{o} \mathrm{\textrm {UO } _ { 2 }}-\mathrm{BeO}$} & -- & -- & -- & $7.25 \times 10^{-7}$ & -- & -- & $1.06\left(\mathrm{Xe}^{137}\right), 1.87\left(\mathrm{I}^{131}\right)$ & $\mathrm{BeO}$ and $\mathrm{UO}_{2}{ }^{(\mathrm{c})}$ & (26) \\
\hline & & & & $7.21 \times 10^{-7}$ & - & -- & $4.10\left(\mathrm{Xe}^{133}\right), 8.22\left(\mathrm{I}^{131}\right)$ & $\mathrm{Be}(\mathrm{OH})_{2}-\mathrm{OH}_{2}(\mathrm{c})$ & (26) \\
\hline & & & & $6.44 \times 10^{-7}$ & - & - & $5.28\left(\mathrm{Xe}^{133}\right), 8.52\left(\mathrm{I}^{131}\right)$ & $\mathrm{BeO}-\mathrm{UO}_{2}(\mathrm{c})$ & $(26)$ \\
\hline
\end{tabular}

(a) Temperatures in brackets not specified whether located on surface or centerline.

(b) Loop (external) pressure on specimens was $2200 \mathrm{psi}$. Specimens under external pressure of 14 psi under simılar irradiation conditions exhıbited up to three times the thickness increase.

(c) Startıng materials. Fission products were collected durıng a postirradıatıon anneal at $1800 \mathrm{~F}$ for $24 \mathrm{hr}$. 
b. In $53.2 \mathrm{w} / \mathrm{o} \mathrm{UO}_{2}-\mathrm{BeO}$ (see Table Gl for irradiation conditions) there was no change in microstructure. Annealing at $1370 \mathrm{C}$ for $4 \mathrm{hr}$ produced no changes in dimensions. (12)

c. In $48.3 \mathrm{w} / \mathrm{UOO}_{2}-\mathrm{BeO}$ (see Table G1) there was no evidence of destruction of $\mathrm{BeO}$ grain structure or formation of gas bubbles or voids. Crushing strength was reduced by as much as one-third, with an average value after irradiation of 68,500 psi. (9) The pellets resistance to abrasion decreased. X-ray diffraction studies showed no change in the c-spacing of the irradiated $\mathrm{BeO}$ matrix, whereas the a-spacing increased 0.74 per cent. Thus the c/a ratio decreased from 1.62 to 1.61 (a 0.62 per cent change). The high irradiation temperature $(1250 \mathrm{C})$ may account for the small amount of damage as compared to low-temperature irradiations (like WAPD experiments). The average fission-fragment density in the $\mathrm{BeO}$ shell around the $\mathrm{UO}_{2}$ particles was calculated to be $2 \times 10^{20}$ fission fragments per $\mathrm{cm}^{3}$, or 0.15 per cent of the total number of beryllium and oxygen atoms present. It was also calculated that each of the beryllium and oxygen atoms within the recoil range of the fuel $(10 \mu)$ was displaced at least once. (10)

d. In $25.3 \mathrm{w} / \circ \mathrm{UO}_{2}, 28.7 \mathrm{w} / \circ \mathrm{UO}_{2}, 30.1 \mathrm{w} / \mathrm{o} \mathrm{UO}_{2}-\mathrm{BeO}$ (see Table Gl) the $\mathrm{UO}_{2}$ exhibited high degree of porosity (fission-gas bubbles). Bubbles were also observed at the $\mathrm{UO}_{2}-\mathrm{BeO}$ interface. Cracks were observed in undamaged regions of the $\mathrm{BeO}$ matrix. It was concluded that the $\mathrm{BeO}$ matrix was destroyed by an impurity effect of fission fragments, rather than through displacement effects. Coarse and fine dispersions had approximately the same fissions per $\mathrm{cm}^{3}$, but the BeO matrix of the coarse dispersion was not completely destroyed. Calculations showed that $\sim 44$ per cent of the $\mathrm{BeO}$ was damaged using $25-\mu \mathrm{UO}_{2}$ particles, whereas only $\sim 5$ per cent was damaged using $150-\mu \mathrm{UO}_{2}$ particles. The amount of swelling per fission (swelling rate) is calculated to be $4.8 \mathrm{x}$ $10^{-23} \mathrm{~cm}^{3}$ per fission. The fine dispersion had greater gas release because the $\mathrm{BeO}$ matrix became amorphous, thus being less dense and allowing higher gas-diffusion rates. (29)

e. In $56 \mathrm{w} / \mathrm{OUO}_{2}, 59 \mathrm{w} / \mathrm{o} \mathrm{\textrm {UO } _ { 2 }}-\mathrm{BeO}$ (see Table Gl) the amount of fission gas released was approximately equal to that expected to be released by recoil, although slightly larger amounts were released from lower density specimens. Postirradiation heating for $4 \mathrm{hr}$ at $1300 \mathrm{C}$ produced no swelling, cracking, or crumbling. There appeared to be no visible deterioration of pellets due to irradiation. The microstructure was unaffected. $(20,24)$

f. In $58.9 \mathrm{w} / \mathrm{O} \mathrm{UO}_{2}-\mathrm{BeO}$ (see Table Gl) the fuel no longer had a definite microstructure. $(21)$

g. In $70 \mathrm{w} / \circ \mathrm{UO}_{2}-\mathrm{BeO}$ (see Table Gl) metallographic examination revealed no voids in the center of the fuel, but spherical voids appeared at the outer edge of fuel particles. Large voids were present at the $\mathrm{UO}_{2}-\mathrm{BeO}$ interface. $X$-ray diffraction showed very little change in the crystal structure of $\mathrm{UO}_{2}$. $\mathrm{BeO}$ showed a slight lattice strain (0.44 per cent). The $\mathrm{UO}_{2}$ lattice contracted 0.07 to 0.26 per cent and showed lattice strains of $0.12-0.18$ per cent. (25) 
h. In $2 \mathrm{w} / \circ \mathrm{UO}_{2}-\mathrm{BeO}$ and $10 \mathrm{w} / 0 \mathrm{UO}_{2}-\mathrm{BeO}$ (see Table $\mathrm{Gl}$ for irradiation conditions) the effects of irradiation on crushing strength have been determined and are shown in Table G5a. The $2 \mathrm{w} / \mathrm{o} \mathrm{UO}_{2}-\mathrm{BeO}$ pellets had lower densities and more variations in strength. The $10 \mathrm{w} / \mathrm{o} \mathrm{UO}_{2}-$ $\mathrm{BeO}$ appears to saturate at a 30 per cent decrease. The elastic modulus also appears to saturate at about a 30 per cent decrease, as shown in Table G5b and Figure G5a. The thermal conductivity decreased by a factor of 4 to 6, as shown in Table G5c and Figure G5b. Recovery of the thermal conductivity started at annealing temperatures of $\sim 600 \mathrm{C}$. Heating for $7 \mathrm{hr}$ at $1000 \mathrm{C}$ in vacuo decreased the thermal-resistivity ratio of $10 \mathrm{w} / 0 \mathrm{UO}_{2-\mathrm{BeO}}$ from 6.75 to 2.5 . It is concluded that $2 \mathrm{w} / \mathrm{o}$ $\mathrm{UO}_{2}-\mathrm{BeO}$ and $10 \mathrm{w} / \mathrm{O} \mathrm{UO}_{2}-\mathrm{BeO}$ dispersions behaved about the same for equal neutron-exposure times, even though fraction of total atoms fissioned was five times greater in the $10 \mathrm{w} / \mathrm{O} \mathrm{UO}_{2}$ specimens. (11) 
TAB LE G5a. EFFECT OF IRRADIATION ON THE CRUSHING STRENGTH $0.25 \mathrm{BY} 0.25-\mathrm{IN}$. BeO-UO 2 CYLINDERS ${ }^{(11)}$

\begin{tabular}{|c|c|c|c|c|}
\hline \multirow[b]{2}{*}{ Material } & \multirow[b]{2}{*}{$\begin{array}{l}\text { Density, } \\
\mathrm{g} \text { per } \mathrm{cm}^{3}\end{array}$} & \multirow{2}{*}{$\begin{array}{c}\text { Fission } \\
\text { Burnup, } \\
\text { a } / o\end{array}$} & \multicolumn{2}{|c|}{ Average Crushing Strength(a) } \\
\hline & & & $\begin{array}{c}\text { Value Obtained, } \\
10^{3} \mathrm{psi}\end{array}$ & $\begin{array}{c}\text { Percentage of } \\
\text { Unirradiated Value }\end{array}$ \\
\hline \multirow[t]{8}{*}{$\mathrm{BeO}-2 \mathrm{w} / \mathrm{o} \mathrm{UO}_{2}$} & 2.4 & 0 & 57.1 & -- \\
\hline & & 0.53 & 53.9 & 94 \\
\hline & & 1.08 & 75.6 & 132 \\
\hline & & 1.86 & 65.0 & 114 \\
\hline & 2.6 & 0 & 131.7 & -- \\
\hline & & 0.53 & 106.6 & 81 \\
\hline & & 1.08 & 115.5 & 88 \\
\hline & & 1.86 & 108.1 & 82 \\
\hline \multirow{8}{*}{$\mathrm{BeO}-10 \mathrm{w} / \mathrm{O} \mathrm{UO}_{2}$} & 2.9 & 0 & 155.1 & -- \\
\hline & & 0.53 & 105.2 & 68 \\
\hline & & 1.08 & $109.0^{(\mathrm{b})}$ & 70 \\
\hline & & 1.86 & 111.8 & 72 \\
\hline & 3.0 & 0 & 188.3 & -- \\
\hline & & 0.53 & 137.2 & 73 \\
\hline & & 1.08 & 144.1 & 77 \\
\hline & & 1.86 & 135.8 & 72 \\
\hline
\end{tabular}

(a) All values based on at least five samples.

(b) The average deviation in this case was 16.3 per cent. In all other cases the average deviation was less than 15 per cent. 
TABLE G5b. EFFECT OF IRRADIATION ON THE ELASTIC MODULUS OF BeO- $\mathrm{UO}_{2}$ PRISMS $(1)$

\begin{tabular}{|c|c|c|c|}
\hline Material & $\begin{array}{l}\text { Density, } \\
\mathrm{g} \text { per } \mathrm{cm}^{3}\end{array}$ & $\begin{array}{l}\text { Fission } \\
\text { Burnup, } \\
\text { a/o }\end{array}$ & $\begin{array}{c}\text { Decrease in Elastic }(a) \\
\text { Modulus, per cent }\end{array}$ \\
\hline \multirow[t]{2}{*}{$\mathrm{BeO}-2 \mathrm{w} / \mathrm{\circ} \mathrm{UO}_{2}$} & 2.79 & $\begin{array}{l}0.53 \\
1.08 \\
1.86\end{array}$ & $\begin{array}{c}21.6 \\
20.2,29.8(25.0) \\
31.6,24.9(28.3)\end{array}$ \\
\hline & 2.84 & $\begin{array}{l}0.53 \\
1.08 \\
1.86\end{array}$ & $\begin{array}{c}17.8 \\
25.3,29.7(27.5)^{(b)} \\
26.5,29.2(27.9)^{(b)}\end{array}$ \\
\hline \multirow[t]{2}{*}{$\mathrm{BeO}-10 \mathrm{w} / \mathrm{\circ} \mathrm{UO}_{2}$} & 2.84 & $\begin{array}{l}0.53 \\
1.08 \\
1.86\end{array}$ & $\begin{array}{c}23.6 \\
25.3,24.9(25.1) \\
30.3,26.2(28.3)\end{array}$ \\
\hline & 3.02 & $\begin{array}{l}1.08 \\
1.86\end{array}$ & $\begin{array}{l}18.4,28.2(23.3) \\
30.3,31.1(30.7)\end{array}$ \\
\hline
\end{tabular}

(a) Average values are given in parentheses.

(b) Preirradiation values unavallable; values are approximations based on similar matenal.

TABLE G5c. EFFECT OF IRRADIATION ON THE THERMAL RESISTIVITY OF $\mathrm{BeO}-\mathrm{UO}_{2}$ PRISMS $^{(1)}$

\begin{tabular}{|c|c|c|c|}
\hline Material & $\begin{array}{l}\text { Density, } \\
\text { g per } \mathrm{cm}^{3}\end{array}$ & $\begin{array}{c}\text { Fission } \\
\text { Burnup, } \\
\text { a/o }\end{array}$ & $\begin{array}{c}\text { Irradiated/Unirradiated } \\
\text { Resistivity Ratio(a) }\end{array}$ \\
\hline \multirow{6}{*}{$\mathrm{BeO}-2 \mathrm{w} / \mathrm{o} \mathrm{UO}_{2}$} & 2. 78 & 0.53 & 4.75 \\
\hline & & 1.08 & 5.25 \\
\hline & & 1.86 & 5.92 \\
\hline & 2.85 & 0.53 & 5.74 \\
\hline & & 1.08 & 6.04 \\
\hline & & 1.86 & 6.56 \\
\hline \multirow[t]{5}{*}{$\mathrm{BeO}-10 \mathrm{w} / \mathrm{o} \mathrm{UO}_{2}$} & 2.85 & 0.53 & 4. 14 \\
\hline & & 1.08 & 4.65 \\
\hline & & 1.86 & 5.66 \\
\hline & 3.01 & 1.08 & 5.54 \\
\hline & & 1.86 & 6.16 \\
\hline
\end{tabular}

(a) All values are averages of several runs, usually on two urradiated and two similar unirradiated prisms. 


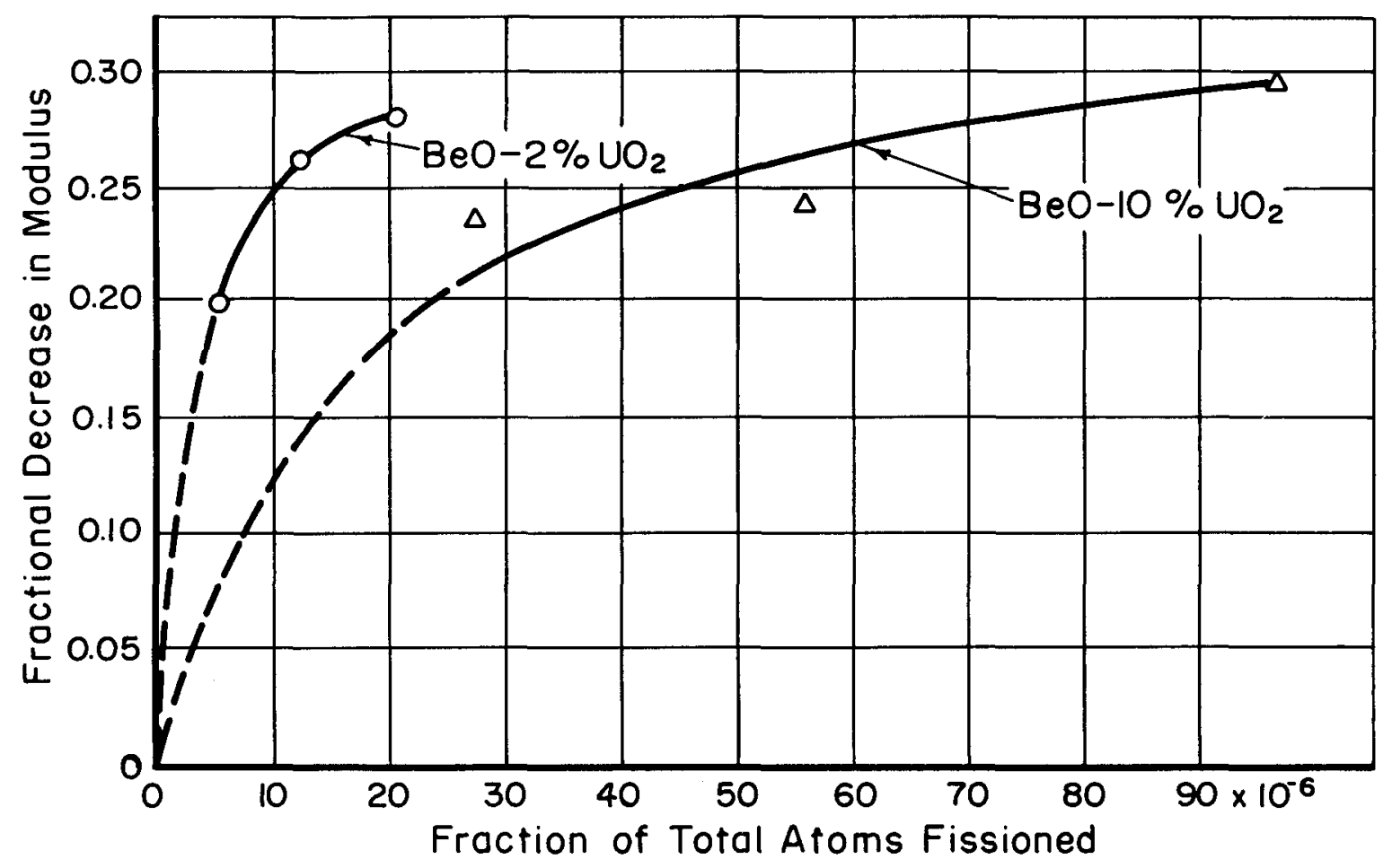

FIGURE G5o. EFFECT OF PILE IRRADIATION ON THE ELASTIC MODULUS OF BEO-UO COMPACTS ${ }^{(11)}$ 
DISP.
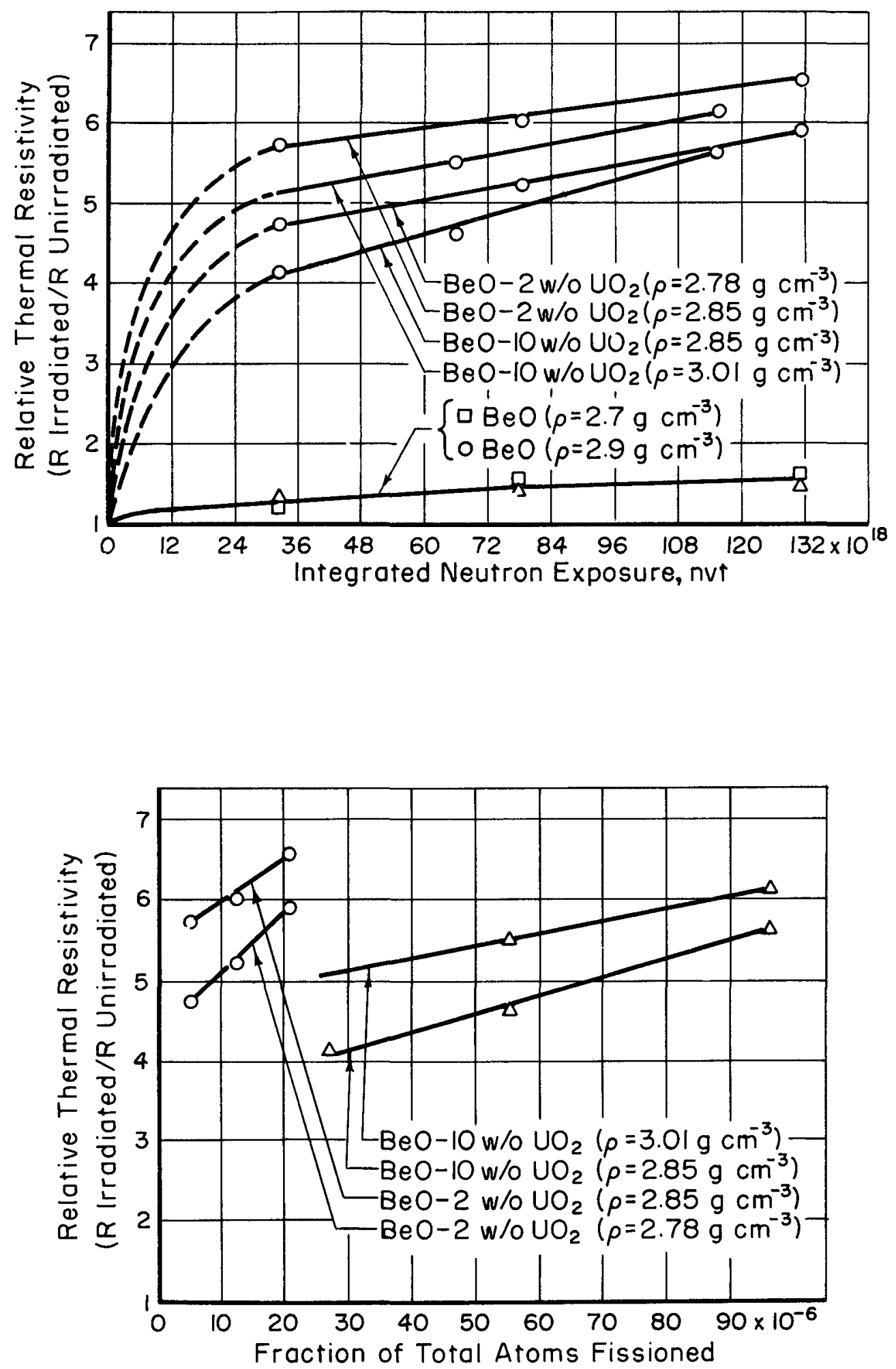

FIGURE G5b. EFFECT OF PILE IRRADIATION ON THE RELATIVE THERMAL RESISTIVITY OF BeO- $\mathrm{UO}_{2}$ COMPACTS $^{(11)}$ 
(1) Budrikov, P. P., Tresvyatsky, S. G, and Kushakovsky, V. I., "Binary Phase Diagrams for $\mathrm{UO}_{2}-\mathrm{Al}_{2} \mathrm{O}_{3}, \mathrm{UO}_{2}-\mathrm{BeO}$, and $\mathrm{UO}_{2}-\mathrm{MgO}$ ", Proceedings of the Second United Nations International Conference on the Peaceful Uses of Atomic Energy, Geneva (1958), A/Conf. 15/P/2193, Vol 6, p 125.

(2) Ward, J. F., and Funk, C. W., "Proceedings of the Beryllium Oxide Meeting Held at Oak Ridge National Laboratory, Oak Ridge Tennessee, December 1-2, 1960", TID-7602 (Pt. 1), (1960).

(3) Bisson, A., and Frisby, H., "Electron Microscope Observation of Porosities, Carbon Inclusions, and Dislocations in Beryllium Oxide Sintered Under Load", J. Nuclear Materials, 4 (2), 133 (1961).

(4) McCreight, L. R., "Thermal Expansion Measurement of Six Fuel Materials", KAPL-M-LRM-7 (1952, Declassified 1957).

(5) "Gas-Cooled Reactor Project, Quarterly Progress Report for Period Ending December 31, 1960", ORNL-3049 (1961).

(6) "Gas-Cooled Reactor Project, Quarterly Progress Report for Period Ending March 31, 1961", ORNL-3102 (1961).

(7) Rothman A. J., "Beryllium Oxide - It's Properties and Applications in Nuclear Reactors", UCRL-6502-T (1961).

(8) Kida, K., Nishigaki, S., and Ueda, R., "A Study of the Fabrication of $\mathrm{BeO}-\mathrm{UO}_{2}$ by Means of Vacuum Hot Pressing", NP-Tr-804 (1961).

(9) Johnson, D. E., and Tobin, J. M., "Proceedings of the Beryllium Oxide Meeting Held at Oak Ridge National Laboratory, Oak Ridge, Tennessee, December 1-2, 1960", TID-7602 (Part 1).

(10) Johnson, D. E., "Stability of $\mathrm{BeO}-\mathrm{UO}_{2}$ Reactor Fuel Materials During Irradiation", GA-2065 (1961).

(11) Gilbreath, J. R., and Simpson, O. C., "The Effect of Reactor Irradiation on the Physical Properties of Beryllium Oxide", Proceedings of the Second United Nations International Conference on the Peaceful Uses of Atomic Energy, Geneva (1958), A/Conf. 15/P/621, Vol 5, p 367.

(12) Johnson, D. E., and Tobin, J. M., "Nuclear Reactor Chemistry, First Conference, Gatlinburg, Tennessee", October 12-14, 1960, TID-7610.

(13) Goldsmith, A., Waterman, T. E., and Hirshhorn, H. O., Handbook of Thermophysical Properties of Solid Materials, Macmillan Co., New York (1961), Vol 3.

(14) McKisson, R. L., "An Evaluation of the Beryllia-Water Vapor Reaction in an Open-Cycle Air Cooled Reactor". J. Nuclear Materials, 1, 196 (1959). 
(15) Grossweiner, L. I., and Seifert, R. L., "The Reaction of Beryllium Oxide With Water Vapor", J. Am. Chem. Soc., 74, 2701 (1952).

(16) Berleman, M. G., and Simon, S. L., "The Volatilization of Beryllia in Water Vapor", ANL-4177 (1948).

(17) Elston, J., and Caillat, R., "Corrosion of BeO", Proceedings of the Second United Nations International Conference on the Peaceful Uses of Atomic Energy, Geneva (1958), A/Conf. 15/P/1147, Vol 5, p 334.

(18) Young, W. A., "The Reactions of Water Vapor With Beryllia and Beryllia-Alumina Compounds", NAA-SR-4446 (1960).

(19) Ohlinger, L. A., "Stability of Beryllium Oxide in Hydrogen at Elevated Temperatures in the Program on the Stability of Refractory Elements and Compounds in a Hydrogen Atmosphere at Elevated Temperatures", NEPA-598 (1948).

(20) Gates, J., "Proceedings of the Beryllium Oxide Meeting Held at Oak Ridge National Laboratory, Oak Ridge, Tennessee, December 1-2, 1960", TID-7602 (Part 1) (1960).

(21) "Gas-Cooled Reactor Program, Quarterly Progress Report for Period Ending December 31, $1961^{\prime \prime}$, ORNL-3254 (1961).

(22) Bleiberg, M. L., Yeniscavich, W., and Gray, R. G., "Effect of Burnup on Certain Ceramic Fuel Materials", WAPD-T-1274 (1961).

(23) Johnson, D. E., Koretzky, J., and Smalley, A. K., "Irradiation of $\mathrm{BeO}-\mathrm{UO}_{2}$ Ceramics", GA-2268 (1961).

(24) Freas, D. G., Saling, J. H., Sheets, H. D., Stang, J. H., Gates, J. E., and Dickerson, R. F., "A Study of the Radiation Stability of $\mathrm{UO}_{2}$ Dispersions in BeO'", BMI- 1484 (1960).

(25) Saling, J. H. , BMI Private Communication (1962).

(26) "Maritime Gas Cooled Reactor Program, Quarterly Progress Report for Period Ending December 31, 1959", GA-1195.

(27) Levy, A., and Foster, J. F., "The Compatibility of Gas Coolants and Ceramic Materials in Coated-Particle Nuclear Fuels", BMI-1530 (1961).

(28) Clarke, F.J.P., and Williams, J., "The Stability of BeO Under Reactor Conditions", AERE-M/M-229 (1959).

(29) Yeniscavich, W., and Bleiberg, M. L., "The Effect of Irradiation on $\mathrm{BeO}+\mathrm{UO}_{2}, \mathrm{ThO}_{2}+\mathrm{UO}_{2}$, and $\mathrm{ZrO}_{2}+\mathrm{CaO}+\mathrm{UO}_{2}{ }^{\prime \prime}, \mathrm{WAPD}-\mathrm{BT}-2 \mathrm{C}$ (1960). 


\section{$\mathrm{UO}_{2}-\mathrm{MgO}$ DISPERSIONS}

Compiled by R. A. Wullaert

Uranium dioxide and magnesium oxide form a limited region of solid solutions in air. The solid solutions have the $\mathrm{UO}_{2}$ crystal structure and contain up to 37 mole per cent of $\mathrm{MgO}$ at temperatures of 1600 to $1750 \mathrm{C}$. The $\mathrm{UO}_{2}-\mathrm{MgO}$ system is not a true condensed system, but some section of the triple $\mathrm{UO}_{2}-\mathrm{MgO}-\mathrm{O}$ system. (1) Thus the $\mathrm{UO}_{2}-\mathrm{MgO}$ system does not give a true dispersion if the temperature is sufficiently high and the $\mathrm{MgO}$ becomes soluble in the $\mathrm{UO}_{2}$.

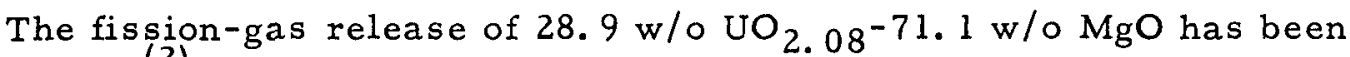
investigated. (2) Gas release was appreciable and nearly constant at temperatures up to $500 \mathrm{C}$, and increased sharply above $600 \mathrm{C}$. A "burst" release effect was observed, and was very marked at high temperatures. It was concluded that the dispersion was of little use in high-temperature gas-cooled reactor applications because of the high gas release.

\section{References}

(1) Budnikov, P. P. , Tresvyatsky, S. G. , and Kushakovsky, V. I. , "Binary Phase Diag rams for $\mathrm{UO}_{2}-\mathrm{Al}_{2} \mathrm{O}_{3}, \mathrm{UO}_{2}-\mathrm{BeO}$, and $\mathrm{UO}_{2}-\mathrm{MgO}^{\prime \prime}$, Proceedings of the Second United Nations International Conference on the Peaceful Uses of Atomic Energy, Geneva (1958), A/Conf. 15/P/2193, Vol 6, p 125.

(2) Stubbs, T. J. , Silver, P. J., and Webster, C. B. , "The Release of Fission Product Rare Gases From Some Ceramic Materials", AERE-C/M-343 (1958). 
One of the main purposes of a fuel dispersion is to provide a matrix material that will give greater radiation stability than that furnished by the dispersed fuel particles alone. Under irradiation, the matrix will restrain the swelling of the fuel particles and retain much of the fission gases released. The additional advantage of a $\mathrm{UO}_{2} / \mathrm{ThO}_{2}-\mathrm{BeO}$ dispersion is that the $\mathrm{UO}_{2}$ is diluted by the $\mathrm{ThO}_{2}$, and for a given burnup of uranium, the fissions per $\mathrm{cm}^{3}$ in the $\mathrm{UO}_{2} / \mathrm{ThO}_{2}$ fuel particles are reduced. This is important because there is a critical number of fissions per $\mathrm{cm}^{3}$ (depending on irradiation conditions) that will cause $\mathrm{UO}_{2}$ to lose its crystal structure and thus its radiation stability.

There has been very little work done on $\mathrm{UO}_{2} / \mathrm{ThO}_{2}-\mathrm{BeO}$ dispersions. In general, the preirradiation properties are probably similar to $\mathrm{UO}_{2}-\mathrm{BeO}$ dispersions, since the $\mathrm{UO}_{2}$ particles are "replaced" by $\mathrm{UO}_{2} / \mathrm{ThO}_{2}$ particles.

The eutectics of the binary systems $\mathrm{UO}_{2}-\mathrm{BeO}$ and $\mathrm{ThO}_{2}-\mathrm{BeO}$ do not occur at the same temperature or relative composition, so the $\mathrm{UO}_{2}-\mathrm{ThO}_{2}-\mathrm{BeO}$ system will not show a true eutectic. However, since the binary eutectic temperatures and compositions are not very different, the $\mathrm{UO}_{2}-\mathrm{ThO}_{2}-\mathrm{BeO}$ system exhibits a quasibinary eutectic at 60 to 80 mole per cent $\mathrm{BeO}$ at approximately $2100 \mathrm{C}$. Therefore, the maximum operating temperature for this type of dispersion is $2100 \mathrm{C}$. $\mathrm{UO}_{2}$ and $\mathrm{ThO}_{2}$ form a complete series of solid solutions, thus providing dilution of the $\mathrm{UO}_{2}$ fuel. (1)

A few irradiations of $\mathrm{UO}_{2} / \mathrm{ThO}_{2}-\mathrm{BeO}$ dispersions have been conducted. The irradiation conditions, dimensional changes, and fission-gas releases are listed in Table 1. Both the dimensional changes and fission-gas release are quite small.

TABLE 1. DIMENSIONAL STABILITY AND GAS RELEASE OF IRRA DIA TED UO $\mathrm{U}_{2} / \mathrm{ThO}_{2}-\mathrm{BeO}$

\begin{tabular}{|c|c|c|c|c|c|c|c|c|}
\hline$\frac{\mathrm{Com}}{\mathrm{UO}_{2}}$ & $\frac{\text { sition, }}{\text { ThO }_{2}}$ & $\frac{\mathrm{N} / \mathrm{O}}{\mathrm{BeO}}$ & $\begin{array}{c}\text { Estimated } \\
\text { Fuel } \\
\text { Temperature, } \\
\text { C }\end{array}$ & $\begin{array}{c}\text { Uranium } \\
\text { Burnup, a/o }\end{array}$ & $\begin{array}{l}\text { Diameter } \\
\text { Change, } \\
\text { per cent }\end{array}$ & $\begin{array}{c}\text { Fission-Gas } \\
\text { Release, } \\
\text { per cent }\end{array}$ & Comments & References \\
\hline \multirow[t]{2}{*}{25.4} & 35.5 & 39.1 & $800-1,100$ & $7.1-10.1$ & +0.6 & $0.3\left(\mathrm{Kr}^{85}\right)$ & $<5-\mu-\operatorname{size} \mathrm{UO}_{2}$ & (2) \\
\hline & & & $800-1,100$ & $7.1-10.1$ & $+1.5^{(a)}$ & -. & & (2) \\
\hline 2.57 & 7.3 & 90.1 & 610 & 13.0 & +0.25 & 0.25 & 100 to $185-\mu \mathrm{UO}_{2}-\mathrm{ThO}_{2}$ & (3) \\
\hline 3.67 & 10.4 & 85.9 & 610 & 13.4 & +0.15 & 0.1 & & (3) \\
\hline 3.67 & 10.4 & 85.9 & 600 & 11.8 & +0.29 & 0.1 & $<10-\mu \mathrm{UO}_{2}-\mathrm{ThO}_{2}$ & \\
\hline 6.43 & 18.3 & 75.3 & 650 & 13.0 & +0.15 & 0.15 & 100 to $185-\mu \mathrm{UO}_{2}-\mathrm{ThO}_{2}$ & (3) \\
\hline 7.34 & 6.8 & 85.9 & 690 & 11.8 & +0.26 & 0.1 & - & (3) \\
\hline 11.5 & 2.7 & 85.8 & 670 & 9.4 & +0.25 & 0.25 & $\ldots$ & (3) \\
\hline 14.8 & 42.0 & 43.2 & 750 & 9.4 & +0.15 & 0.3 & - & (3) \\
\hline 16.3 & 29.3 & 60.4 & 620 & 11.7 & +0.21 & 0.35 & -. & (3) \\
\hline
\end{tabular}

(a) Irradiated in air. 


\section{References}

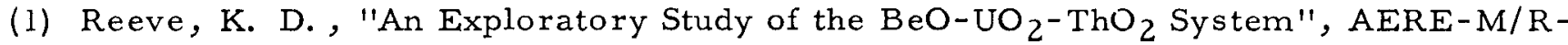
2727 (1958).

(2) "Gas-Cooled Reactor Program, Quarterly Progress Report for Period Ending December 31, 1961", ORNL-3254 (1961).

(3) Hickman, B. S., and Hilditch, R. J., AAEC, "The Ir radiation Behavior of Beryllium Oxide Based Dispersion Fuels", To Be Published. 
DISP.

\section{DISPERSIONS OF UNCOATED FUEL IN GRAPHITE}

Compiled by M. C. Brockway, and A. B. Tripler

\section{Al. Chemical composition}

Property data versus uranium content are given in succeeding sections for fuel loadings up to $50 \mathrm{w} / \mathrm{o}$ uranium as either $\mathrm{UO}_{2}$ or $\mathrm{UC}_{2}$.

\section{Effect of impurities}

a. Graphite is not a single material but a family of materials whose properties may vary broadly depending on choice of production materials and processing. The properties of fueled graphite depend also on the form of dispersed fuel and the loadings. Thus, no single set of properties can be representative of graphite matrix fuel dispersions in general.

b. Impurity content of graphite (carbon) matrices is strongly dependent upon the maximum process temperature as shown in Tables A3a and A3b.

TABLE A3a. TYPICAL TRACE IMPURITY CONTENTS OF FUELED GRAPHITE(1)

\begin{tabular}{lcr}
\hline & \multicolumn{2}{c}{ Impurity Content $(\mathrm{a})(\mathrm{b}), \mathrm{ppm}$} \\
\cline { 2 - 3 } Element & 20 & $1400 \mathrm{C}$ Bake \\
\hline Iron & 1 & 200 \\
Boron & $<0.5$ & 2 \\
Silicon & $<0.01$ & 120 \\
Magnesium & $<0.05$ & 20 \\
Copper & $<0.1$ & 20 \\
Aluminum & 1 & 10 \\
Titanium & $<1$ & 10 \\
Vanadium & $<0.01$ & 60 \\
Silver & 5 & 1 \\
Calcium & 2 & 50 \\
Sodium & 20 & 5 \\
Potassium & $<3$ & 25 \\
Chromium & $<1$ & 4 \\
Manganese & $<1$ & 40 \\
Nickel & & 200 \\
& & \\
\hline
\end{tabular}

(a) Other elements if present were less than the following minimum detectable concentration $(\mathrm{ppm})$ : $\mathrm{Pb}(<1), \mathrm{Zn}(<1), \mathrm{As}(<30), \mathrm{Sn}(<1), \mathrm{Zr}(<3), \mathrm{Sb}(<1)$, $\mathrm{Bi}(<1), \mathrm{P}(<30), \mathrm{Co}(<3), \mathrm{Mo}(<3)$, and $\mathrm{Ba}(<1)$.

(b) Data were obtained from fueled graphite containing $5 \mathrm{w} / \mathrm{o} \mathrm{UO} 2$ spheroids processed to the maximum indicated temperatures. Final fuel form for the $1400 \mathrm{C}$ bake was $\mathrm{UO}_{2}$; for the $2800 \mathrm{C}$ graphitization, $\mathrm{UC}_{2}$. 
TABLE A3b. HYDROGEN CONTENT OF FUELED GRAPHITE AS RELATED TO MAXIMUM HEAT TREATMENT(1)

\begin{tabular}{crrr}
\hline \multirow{2}{*}{$\begin{array}{c}\text { Maximum Baking }(\mathrm{a}) \\
\text { Temperature, } C\end{array}$} & \multicolumn{3}{c}{ Hydrogen Content, } \\
\cline { 2 - 4 } & Average & Maximum & Minimum \\
\hline 700 & 6200 & 6370 & 6080 \\
1000 & 1030 & 1110 & 840 \\
1400 & 230 & 300 & 200 \\
1800 & 25 & 30 & 10 \\
2200 & 56 & 110 & 20 \\
2400 & 98 & 150 & 50 \\
2800 & 68 & 170 & 10 \\
\hline
\end{tabular}

(a) Fueled graphite was prepared by addition of ceramic-grade $\mathrm{UO}_{2}$ to a carbonaceous mix which was then formed and baked to the maximum indicated temperature. The considerable range of hydrogen content found for temperatures between 1800 and $2800 \mathrm{C}$ correlated with the extent of fueled-compact exposure to the atmosphere between heat treatment and analysis. The lower values should be attainable by thorough protection of the carbide fuel from hydrolysis.

B1. Density (room temperoture) $)^{(2)}$

See Table B1.

TABLE B1. ROOM-TEMPERATURE DENSITY AS RELATED

TO FUEL LOADING IN UO2-GRAPHITE AND

$\mathrm{UC}_{2}$-GRAPHITE COMPACTS (2)

\begin{tabular}{|c|c|c|c|c|c|}
\hline \multicolumn{3}{|c|}{ UO2-Graphite Compacts } & \multicolumn{3}{|c|}{$\mathrm{UC}_{2}$-Graphite Compacts } \\
\hline $\begin{array}{l}\text { Uranium, } \\
\text { w/o }\end{array}$ & $\begin{array}{c}\text { Compact } \\
\text { Density (a), } \\
\text { g per } \mathrm{cm}^{3}\end{array}$ & $\begin{array}{c}\text { Fuel } \\
\text { Content }(\mathrm{c}) \\
\mathrm{g} \text { per } \mathrm{cm}^{3}\end{array}$ & $\begin{array}{c}\text { Uranium, } \\
\text { w/o }\end{array}$ & $\begin{array}{c}\text { Compact } \\
\text { Density } \\
\text { g per } \mathrm{cm}^{3}\end{array}$ & $\begin{array}{c}\text { Fuel } \\
\text { Content }(\mathrm{c}), \\
\mathrm{g} \text { per } \mathrm{cm}^{3}\end{array}$ \\
\hline 0 & 1.69 & 0 & 0 & 1.79 & 0 \\
\hline 2.9 & 1.72 & 0.05 & 10 & 1.89 & 0.19 \\
\hline 9.8 & 1.83 & 0.18 & 20 & 1.99 & 0.40 \\
\hline 19 & 2.01 & 0.38 & 25 & 2.07 & 0.52 \\
\hline 29 & 2.22 & 0.64 & 31 & 2.16 & 0.67 \\
\hline 36 & 2.44 & 0.88 & 40 & 2.33 & 0.93 \\
\hline 45 & 2.69 & 1.21 & 50 & 2.53 & 1.27 \\
\hline
\end{tabular}

(a) Maximum bake temperature $1425 \mathrm{C}$.

(b) Maximum graphitization temperature $2800 \mathrm{C}$.

(c) Maximum theoretical fuel density based on $U^{238}$.

\section{Density versus temperature}

No data available 
DISP.

\section{Utranium content}

See Table B 1 .

\section{Liquidus temperature}

The upper operating limit of the fueled composite will be dependent on reaction of fuel phase with the graphite or on fuel migration. Studies at ORNL(3) showed the reaction between minus 60 plus $80-$ mesh $\mathrm{UO}_{2}$ and graphite at pressures of $1 \times 10^{-3}$ to $1 \times 10^{-4} \mathrm{~mm}$ of mercury fit the rate equation,

$$
x=k t^{1 / 2} \text {, }
$$

where $\mathrm{x}$ is the fraction of $\mathrm{UO}_{2}$ converted to carbide, $\mathrm{k}$ is the temperaturedependent rate constant, and $t$ is time in hours, at temperature. The values of $\mathrm{k}$ obtained were $0.18,0.33$, and 0.44 at 1275,1325 , and $1375 \mathrm{C}$, respectively. Comparison of these results with those obtained for minus 325mesh $\mathrm{UO}_{2}$, indicated that the reaction rate was insensitive to particle size below about $1325 \mathrm{C}$ and relatively insensitive above this temperature.

6. Vopor pressure

No data available on fueled graphite.

\section{Thermal expansion (lineor) $(1,2)$}

See Table B $7 \mathrm{a}$ and Table B $7 \mathrm{~b}$.

TABLE B7a. THERMAL EXPANSION VERSUS FUEL LOADING OF $\mathrm{UO}_{2}$-GRAPHITE COMPACTS(2)

\begin{tabular}{ccc}
\hline & \multicolumn{2}{c}{$\begin{array}{c}\text { Mean Thermal-Expansion Coefficient } \\
\text { Uranium } \\
\text { w/o }\end{array}$} \\
\cline { 2 - 3 } & With the Grain $(\mathrm{b})$ & Across the Grain $(\mathrm{b})$ \\
\hline 0 & $2.81^{-6}$ & 4.75 \\
2.9 & 2.37 & 4.37 \\
9.8 & 2.26 & 3.94 \\
19 & 2.48 & 3.85 \\
29 & 2.47 & 4.19 \\
36 & 2.56 & 4.06 \\
45 & 2.40 & 4.07 \\
\hline
\end{tabular}

(a) Fueled compacts baked to $1425 \mathrm{C}$.

(b) W'th the grain" and "across the grain" correspond to directions perpendicular and parallel, respectively, to the direction of applied force in molding the green compacts. 


\section{TABLE B7b. THERMAL EXPANSION VERSUS FUEL LOADING OF $\mathrm{UC}_{2}$-GRAPHITE COMPACTS (1)}

\begin{tabular}{c}
$\begin{array}{c}\text { Uranium } \\
\text { w/o }\end{array}$ \\
\hline 0 \\
2.9 \\
9.8 \\
20 \\
31 \\
40 \\
50
\end{tabular}

Mean Thermal-Expansion Coefficient $(25-540 \mathrm{C})^{(\mathrm{b})}, 10^{-6}$ per $\mathrm{C}$ With the Grain Across the Grain

3.06

4.54

2. 9

3.06

4. 85

9.8

3. 50

5. 48

3. 44

5. 11

31

3. 58

5.09

50

3.92

5.70

5.01

$8.34^{(c)}$

(a) Maximum graphitization temperature, $2350 \mathrm{C}$.

(b) Measured in vacuo $\left(\sim 4 \times 10^{-5} \mathrm{~mm}\right.$ of mercury), or in purified helium.

(c) Doubtful value, slight oxidation of $\mathrm{UC}_{2}$ fuel may have occurred in this case.

\section{C1. Hordness (room temperoture)}

No data for fueled graphite

\section{Ultimate tensile strength}

a. Room-temperature flexural (bend) strength values are shown in Tables C3a(1) and $\mathrm{C} 3 \mathrm{a}(2)$

TABLE C3a(1). FLEXURAL STRENGTH VERSUS FUEL LOADING OF $\mathrm{UO}_{2}$-GRAPHITE COMPACTS $(2)$

\begin{tabular}{ccc}
\hline \multirow{2}{*}{$\begin{array}{c}\text { Eranium } \\
\text { w/o }\end{array}$} & \multicolumn{2}{c}{ Flexural Strength $(\mathrm{b})$, psi } \\
\cline { 2 - 3 } & With the Grain & Across the Grain \\
\hline 0 & 10,200 & 6,340 \\
9.9 & 12,000 & 7,560 \\
19 & 9,450 & 6,600 \\
29 & 7,600 & 6,160 \\
36 & 9,740 & 6,940 \\
45 & 8,490 & 5,550 \\
\hline \hline
\end{tabular}

(a) Fueled compacts baked to $1425 \mathrm{C}$.

(b) The strength data were determined using single-point loading at a rate of $42 \mathrm{lb}$ per min with a $0.625-1 n$. span. 
TABLE C3a(2). FLEXURAL STRENGTH VERSUS FUEL LOADING OF $\mathrm{UC}_{2}$-GRAPHITE COMPACTS (2)

\begin{tabular}{ccc}
\hline Uranium $_{\text {w/o }}^{(a)}$ & \multicolumn{2}{c}{ Flexural Strength $(\mathrm{b})$, psi } \\
\cline { 2 - 3 } & With the Grain & Across the Grain \\
\hline 0 & 8090 & 5900 \\
20 & 5670 & 4060 \\
25 & 4350 & 2840 \\
31 & 3790 & 2670 \\
40 & 3430 & 2790 \\
50 & 3230 & 2270 \\
\hline
\end{tabular}

(a) Fueled compacts baked to $2800 \mathrm{C}$.

(b) The strength data were determuned using single-point loading at a rate of $42 \mathrm{lb}$ per min with a $0.625-1 n$. span.

b. Elevated-temperature tensile strength data have been reported by Wagner (4) for an unfueled experimental grade, CK, three fueled grades (fuel added to the base CK grade), LDH, LDC, LDP, and a commercial unfueled grade, H4LM. Figure C3 presents these data.

\section{Yield strength}

No data available

5. Compressive strength ${ }^{(5)}$

See Tables C5a and C5b.

TABLE C5a. COMPRESSIVE STRENGTH VERSUS FUEL LOADING OF URANIUM CARBIDEGRAPHITE COMPACTS $(5)$

\begin{tabular}{cc}
\hline & \\
$\begin{array}{c}\text { Uranium, } \\
\text { w/o }\end{array}$ & $\begin{array}{c}\text { Compressive } \\
\text { Strength(a) } \\
\text { psi }\end{array}$ \\
\hline 0 & 10,070 \\
3.9 & 9,060 \\
11.7 & 8,300 \\
20.8 & 5,570 \\
23.7 & 5,520 \\
30.3 & 5,940 \\
\hline
\end{tabular}

(a) Compacts baked to $2800 \mathrm{C}$. Strength was probably measured against the grain but reference is not specific. 


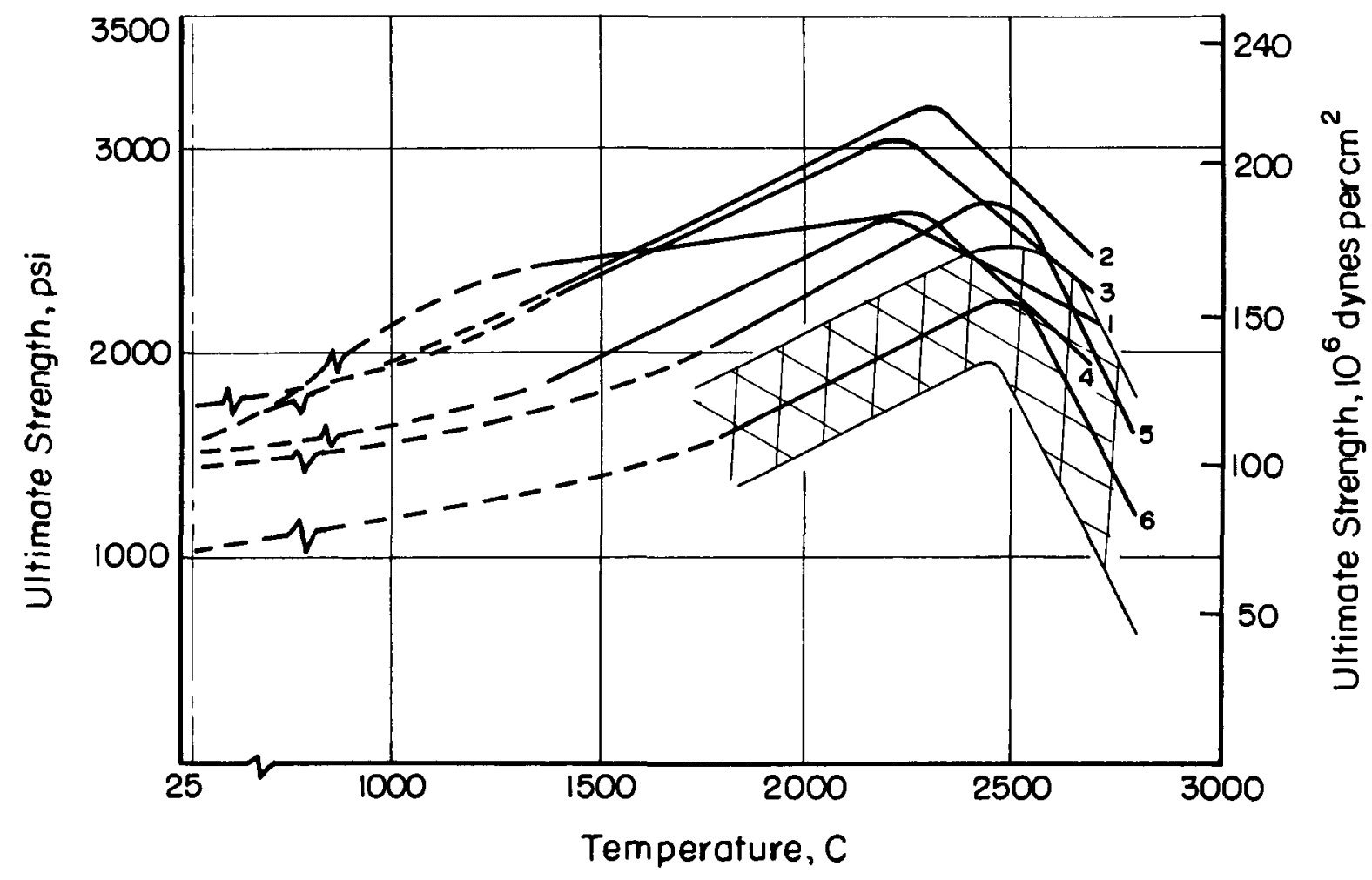

FIGURE C3. GRAPHITE ULTIMATE TENSILE STRENGTHAS A FUNCTION OF TEMPERATURE ${ }^{(4)}$

I CK

$2 \operatorname{LDH}\left(\frac{1}{8} g \operatorname{per} \mathrm{cm}^{3} \mathrm{U}\right)$

$3 \operatorname{LDC}\left(\frac{1}{4} g \operatorname{per} \mathrm{cm}^{3} \mathrm{U}\right)$

$4 \operatorname{LDP}\left(0.35 \mathrm{~g} \operatorname{cer} \mathrm{cm}^{3} \mathrm{U}\right)$

5 H4LM

6 H4LM (perpendicular to grain, all others parallel) 
DISP.

TABLE C5b. COMPRESSIVE STRENGTH VERSUS FUEL

LOADING OF URANIUM OXIDE-

GRAPHITE COMPACTS (5)

\begin{tabular}{cc}
\hline $\begin{array}{c}\text { Uranium, } \\
\text { w/o }\end{array}$ & $\begin{array}{c}\text { Compressive } \\
\text { Strength(a) } \\
\text { psi }\end{array}$ \\
\hline 0 & 15,800 \\
3.8 & 18,600 \\
11.7 & 18,990 \\
19.9 & 14,100 \\
\hline
\end{tabular}

(a) Compacts baked to $1450 \mathrm{C}$. Strength was probably measured against the grain.

\section{Creep strength}

a. The creep of carbon (graphite) bodies depends not only on the stress applied and the temperature, but also on the previous thermal history of the material, and the form of carbon from which the body was made. In the case of fueled graphite, the effect of fuel loading is added.

b. Wagner ${ }^{(4)}$ has published high-temperature creep data for both fueled and unfueled graphites. Under constant temperature and stress, two types of compressive-creep curves were observed. Type A consisted of an initial rapid creep, a second-stage "steady state", and an accelerated third stage terminating in fracture. Type $B$ exhibited a rapid initial creep followed by a "steady-state" second stage extending to fracture. Type B was most commonly observed, and an approximate correlation of the "steady-state" region of the compressive-creep curves was obtained by the empirical equation:

$$
\frac{d \epsilon}{d t}=\dot{\epsilon}=K\left(\sigma / \sigma_{B}\right) \exp n_{e}-E_{a} / R T
$$

where $\dot{\epsilon}$ is negative in compression and

$\epsilon \quad=$ steady-state (second-stage) creep rate, $\sec ^{-1}$

$\mathrm{K}, \mathrm{n}=$ empirical constants, $\mathrm{K}$ in $\mathrm{sec}^{-1}$

$\sigma \quad=$ stress applied to produce $\dot{\epsilon}$, dynes per $\mathrm{cm}^{2}$

$\sigma_{B}=$ stress required to produce failure of the particular sample being tested, dynes per $\mathrm{cm}^{2}$

$\mathrm{E}_{\mathrm{a}}$ = activation energy, cal per mole

$\mathrm{R}=$ universal gas constant, $\mathrm{cal} /($ mole $)(\mathrm{C})$

$\mathrm{T}=$ temperature, $\mathrm{K}$. 
All the Type B data (failure without third-stage creep) were correlated by a single set of constants. The final working equation was

$$
\dot{\epsilon}=-40\left(\sigma / \sigma_{B}\right) \exp 3.8 e^{-50,000 / R T} .
$$

Creep data for five types of graphite reported by Wagner are given in Table $\mathrm{C} 6 \mathrm{~b}(1)$.

TABLE C6b(1). SUMMARY OF STEADY -STATE CREEP RATES OF GRAPHITE IN COMPRESSION. COMPARISON OF EXPERIMENTAL CREEP RATES AND CREEP RATES CALCULATED BY EQUATION 1 (4)

\begin{tabular}{|c|c|c|c|c|c|c|}
\hline \multirow[b]{2}{*}{ Sample } & \multirow{2}{*}{$\begin{array}{c}\text { Graphite } \\
\text { Type } \\
\end{array}$} & \multirow{2}{*}{$\begin{array}{c}\text { Grain } \\
\text { Orientation }\end{array}$} & \multirow{2}{*}{$\begin{array}{c}\text { Temperature, } \\
\mathrm{K}\end{array}$} & \multirow{2}{*}{$\frac{\sigma}{\sigma_{\mathrm{B}}}$} & \multicolumn{2}{|c|}{ Creep Rate, $\dot{\epsilon}, 10^{-5}$ per Sec } \\
\hline & & & & & Measured & Calculated(a) \\
\hline \multirow[t]{2}{*}{1} & \multirow[t]{2}{*}{ H4LM ${ }^{(b)}$} & \multirow[t]{2}{*}{ Paralle1 } & \multirow[t]{2}{*}{2270} & 0.67 & -0.89 & -0.60 \\
\hline & & & & 0.81 & -0.89 & -1.1 \\
\hline \multirow[t]{2}{*}{2} & \multirow[t]{2}{*}{ H4LM } & \multirow[t]{2}{*}{ Parallel } & \multirow[t]{2}{*}{2530} & 0.78 & -4.9 & -3.3 \\
\hline & & & & 0.86 & -5.2 & -4.8 \\
\hline \multirow[t]{2}{*}{3} & \multirow[t]{2}{*}{$\mathrm{H} 4 \mathrm{LM}$} & \multirow[t]{2}{*}{ Parpendicular } & 2570 & 0.70 & -1.2 & -2.5 \\
\hline & & & 2570 & 0.78 & -2.3 & -3.8 \\
\hline \multirow[t]{3}{*}{4} & \multirow{3}{*}{$\mathrm{CK}-57^{(\mathrm{c})}$} & \multirow[t]{3}{*}{ Parallel } & \multirow[t]{3}{*}{2400} & 0.80 & -2.3 & -2.1 \\
\hline & & & & 0.93 & -3.1 & -3.7 \\
\hline & & & & 1.00 & -4.3 & -4.9 \\
\hline 5 & $\mathrm{CK}-56$ & Parallel & 2760 & 0.84 & -5.2 & -9.8 \\
\hline 6 & $\mathrm{CK}-56$ & Parallel & 2760 & 1.00 & -25 & -19 \\
\hline \multirow[t]{2}{*}{7} & \multirow[t]{2}{*}{$L D H-10^{(d)}$} & \multirow[t]{2}{*}{ Parallel } & \multirow[t]{2}{*}{2280} & 0.75 & -1.3 & -0.96 \\
\hline & & & & 0.91 & -5.8 & -2.0 \\
\hline 8 & $L D H-10$ & Parallel & 2560 & 1.00 & -3.2 & -9.5 \\
\hline \multirow[t]{2}{*}{9} & \multirow[t]{2}{*}{ LDH -10} & \multirow[t]{2}{*}{ Parallel } & \multirow[t]{2}{*}{2750} & 0.76 & -3.9 & -6.6 \\
\hline & & & & 0.90 & -11 & -12.5 \\
\hline 10 & $\mathrm{LDH}-12$ & Parallel & 2760 & 1.00 & -19 & -19 \\
\hline 11 & $\mathrm{LDH}-12$ & Parallel & 2760 & 0.78 & -9.2 & -7.4 \\
\hline \multirow[t]{3}{*}{12} & \multirow[t]{3}{*}{ LDC-16(e) } & \multirow[t]{3}{*}{ Paiallel } & \multirow[t]{3}{*}{2430} & 0.61 & -0.80 & -0.86 \\
\hline & & & & 0.70 & -1.4 & -1.4 \\
\hline & & & & 0.90 & -18 & -3.8 \\
\hline 13 & $L D C-15$ & Parallel & 2570 & 1.00 & -9.5 & -9.8 \\
\hline 14 & LDC-15 & Parallel & 2720 & 0.83 & -8.2 & -8.3 \\
\hline
\end{tabular}

(a) Calculated by Equation 1 (see C6b in text).

(b) An unfueled commercial grade of graphite.

(c) $\mathrm{CK}$ is unfueled experimental graphite.

(d) LDH is CK -type graphite fueled with $125 \mathrm{mg}$ of uranium per $\mathrm{cm}^{3}$ of carbon.

(e) LDC is CK-type graphite fueled with $250 \mathrm{mg}$ of uranium per $\mathrm{cm}^{3}$ of carbon.

In the case of tensile creep, the rate was found to depend upon the uranium content in addition to the other variables. The empirical equation used to correlate the "steady-state" region of these creep curves was

$$
\dot{\epsilon}=f(U) K\left(\sigma / \sigma_{B}\right) \exp n_{e}-E_{a} / R T .
$$

Within the conditions studied, $f(U)$ took the form

$$
f(U)=a+b U+C U^{2} .
$$


DISP.

Inserting the empirically determined constants, the correlation for

"steady-state" tensile creep was:

$$
\epsilon=\left(4+80 U-125 U^{2}\right)\left(\sigma / \sigma_{B}\right) \exp 3.8 e^{-69,000 / R T} \cdot \text { (Equation 2) }
$$

Table $\mathrm{C} 6 \mathrm{~b}(2)$ lists creep data obtained for four unfueled and three fueled graphites.

Green $(6)$ has published creep data for the same types of fueled graphites at stress levels of 1630,2130 , or $2540 \mathrm{psi}$, and temperatures of 2000 , 2200 , and $2400 \mathrm{C}$. These data were not correlated by an empirical equation.

7. Young's modulus

No data available

8. Sheor modulus

No data available

9. Bulk modulus

No data available

10. Poisson's ratio

No data available 
TABLE C6b(2). SUMMARY OF STEADY -STATE CREEP RATES OF GRAPHITE IN TENSION AND COMPARISON OF C6b EXPERIMENTAL CREEP RATES AND CREEP RATES CALCULATED BY EQUATION 2(4)

\begin{tabular}{|c|c|c|c|c|c|c|}
\hline Sample & $\begin{array}{c}\text { Graphite } \\
\text { Type }\end{array}$ & $\begin{array}{c}\text { Grain } \\
\text { Orientation } \\
\end{array}$ & $\begin{array}{c}\text { Temperature, } \\
\mathrm{K}\end{array}$ & $\frac{\sigma}{\sigma_{\mathrm{B}}}$ & $\frac{\text { Creep Rat }}{\text { Measured }}$ & $\frac{10^{-5} \text { per } \mathrm{Sec}}{\text { Calculated }(\mathrm{a})}$ \\
\hline 1 & H4LMI(b) & Parallel & 2270 & 0.73 & 0.13 & 0.27 \\
\hline 2 & H4LM & Parallel & 2380 & 0.77 & 0.18 & 0.70 \\
\hline 3 & HALM & Perpendicular & 2730 & 0.82 & 0.36 & 0.42 \\
\hline 4 & $\mathrm{H} 4 \mathrm{LM}$ & Parallel & 2770 & 0.77 & 0.16 & 0.57 \\
\hline 5 & H4LM & Parallel & 2770 & 1.0 & 1.2 & 1.5 \\
\hline 6 & $\mathrm{H} 4 \mathrm{LM}$ & Parallel & 2800 & 0.83 & 1.0 & 0.81 \\
\hline 7 & $\mathrm{H} 4 \mathrm{LM}$ & Parallel & 3270 & 0.55 & 1.5 & 1.0 \\
\hline 8 & H4LM & Perpendicular & 3270 & 0.75 & 2.3 & 3.4 \\
\hline \multirow[t]{2}{*}{9} & $\mathrm{CK}-68(\mathrm{c})$ & Parallel & 2360 & 0.80 & 0.06 & 0.07 \\
\hline & & & & 0.94 & 0.12 & 0.13 \\
\hline \multirow[t]{2}{*}{10} & LDI -19 (d) & Parallel & 2350 & 0.76 & 0.13 & 0.16 \\
\hline & & & & 0.90 & 0.35 & 0.32 \\
\hline \multirow[t]{3}{*}{11} & $L D C-38(e)$ & Parallel & 2350 & 0.64 & 0.12 & 0.10 \\
\hline & & & & 0.79 & 0.21 & 0.22 \\
\hline & & & & 0.93 & 0.34 & 0.41 \\
\hline \multirow[t]{3}{*}{12} & $L D P-41(f)$ & Parallel & 2350 & 0.73 & 0.11 & 0.13 \\
\hline & & & & 0.84 & 0.13 & 0.22 \\
\hline & & & & 1.0 & 0.27 & 0.43 \\
\hline \multirow[t]{3}{*}{13} & $\mathrm{CK}-68$ & Parallel & 2700 & 0.63 & 0.39 & 0.19 \\
\hline & & & & 0.84 & 0.66 & 0.57 \\
\hline & & & & 0.98 & 0.90 & 1.0 \\
\hline \multirow[t]{4}{*}{14} & LDH -19 & Parallel & 2680 & 0.56 & 0.46 & 0.35 \\
\hline & & & & 0.75 & 0.57 & 1.0 \\
\hline & & & & 0.88 & 0.83 & 1.8 \\
\hline & & & & 1.0 & 1.1 & 3.0 \\
\hline \multirow[t]{5}{*}{15} & LDC -38 & Parallel & 2730 & 0.54 & 0.51 & 0.41 \\
\hline & & & & 0.62 & 0.86 & 0.71 \\
\hline & & & & 0.74 & 1.6 & 1.4 \\
\hline & & & & 0.82 & 2.3 & 2.1 \\
\hline & & & & 1.0 & 5.4 & 4.3 \\
\hline \multirow[t]{3}{*}{16} & LDP-41 & Parallel & 2700 & 0.75 & 0.62 & 1.0 \\
\hline & & & & 0.81 & 0.79 & 1.4 \\
\hline & & & & 0.97 & 1.7 & 3.0 \\
\hline 17 & $\mathrm{ATJ}^{(\mathrm{b})}$ & Parallel & 2770 & 0.68 & 1.2 & 0.35 \\
\hline 18 & $\mathrm{ATJ}$ & Parpendicular & 2770 & 0.68 & 1.5 & 0.35 \\
\hline 19 & ATJ & Parallel & 2770 & 0.74 & 3.4 & 0.46 \\
\hline 20 & $\mathrm{CS}-312(\mathrm{~b})$ & Parallel & 2270 & 0.81 & 0.024 & 0.042 \\
\hline 21 & CS -312 & Parallel & 3270 & 1.0 & 4.8 & 9.6 \\
\hline 22 & CS -312 & Perpendicular & 3270 & 0.89 & 5.5 & 6.4 \\
\hline
\end{tabular}

(a) Calculated by Equation 2 (see C6b in text).

(b) H4LM, ATJ, and CS are three commercial grades of unfueled graphite.

(c) $\mathrm{CK}$ is an unfueled experimental grade.

(d) LDH is Grade CK fueled with $125 \mathrm{mg}$ of uranium per $\mathrm{cm}^{3}$ of carbon.

(e) LDC 1 s Grade CK fueled with $250 \mathrm{mg}$ of uranium per $\mathrm{cm}^{3}$ of carbon.

(f) LDP is Grade CK fueled with $350 \mathrm{mg}$ of uranium per $\mathrm{cm}^{3}$ of carbon. 
DISP.

D1. Specific heot $(3,7)$

Data obtained for TREAT (3) urania fueled graphite indicate a linear relation between temperature and $C_{p}$ over the temperature range 200 to $1000 \mathrm{C}$, as shown by the data in Table Dl. This fueled graphite contained $0.211 \mathrm{w} / 0$ uranium. The dispersed fuel particles were $44 \mu$ in diameter, and the maximum processing (bake) temperature was $900 \mathrm{C}$.

TABLE DI. SPECIFIC HEAT

OF FUELED

GRAPHITE(7)

\begin{tabular}{cc}
\hline $\begin{array}{c}\text { Temperature, } \\
\mathrm{C}\end{array}$ & $\begin{array}{c}\text { Specific Heat, } \\
\mathrm{cal} /(\mathrm{g})(\mathrm{C})\end{array}$ \\
\hline 205 & 0.304 \\
315 & 0.331 \\
425 & 0.358 \\
540 & 0.385 \\
650 & 0.412 \\
760 & 0.439 \\
870 & 0.466 \\
980 & 0.493 \\
\hline
\end{tabular}

\section{Thermal conductivity $(2,4,5)$}

a. Data for fueled graphite are shown in Tables D2a(1) and D2a(2).

TABLE D2a (1). THERMAL CONDUCTIVITY

VERSUS FUEL CONTENT

OF $\mathrm{UO}_{2}$-GRAPHITE

COMPAC TS $(2)$

\begin{tabular}{|c|c|c|}
\hline \multirow{2}{*}{$\begin{array}{c}\text { Ur anium, } \\
\text { w/o }\end{array}$} & \multicolumn{2}{|c|}{$\begin{array}{l}\text { The rmal Conductivity }(\mathrm{a}) \text {, } \\
\mathrm{cal} /(\mathrm{sec})(\mathrm{cm})(\mathrm{C})\end{array}$} \\
\hline & With the Grain & Across the Grain \\
\hline 0 & 0.0984 & 0.0740 \\
\hline 2.9 & 0.0806 & 0.0521 \\
\hline 9.8 & 0.0798 & 0.0529 \\
\hline 19 & 0.0732 & 0.0521 \\
\hline 29 & 0.0634 & 0.0500 \\
\hline 36 & 0.0595 & 0.0430 \\
\hline 45 & 0.0508 & 0.0351 \\
\hline
\end{tabular}

(a) Compacts were baked to $1425 \mathrm{C}$. Room-temperature conductivity data are given. 


\section{I'ALLE D2a (2). THERMAL CONDUCTIVITY VERSUS FUEL LOADING OF URANIUM CARBIDE- GRAPHITE COMPACTS ${ }^{(5)}$}

\begin{tabular}{cc}
$\begin{array}{c}\text { Uranium, } \\
\text { w/o }\end{array}$ & $\begin{array}{c}\text { Thermal Conductivity (a), } \\
\mathrm{cal} /(\mathrm{sec})(\mathrm{cm})(\mathrm{C})\end{array}$ \\
\hline 0 & 0.11 \\
3.9 & 0.11 \\
11.7 & 0.13 \\
20.8 & 0.14 \\
23.7 & 0.15 \\
\hline
\end{tabular}

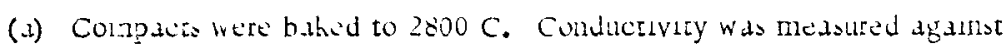
the grail d: room temaparature.

b. Wagner ${ }^{(4)}$ has reported thermal conductivity as a function of temperature for two unfueled graphites (H4LM, a commercial graphite, and CK, an expermental grade), and for two fueled graphites (I DH containing $0.125 \mathrm{~g}$ of uranium per $\mathrm{cm}^{3}$, LDC containing $0.250 \mathrm{~g}$ of uranium per $\mathrm{cm}^{3}$ ). The data, $3 s$ shown in Figure D2b, indicate apparent lack of dependence of conductivity on fuel loading for these fuels and loading levels.

\section{E1. Electrical resistivity (2)}

See Tables Ela and Elb.

IABLE Ela. ELECTRICAL RESISTIVITY VERSUS FUEL LOADING OF UO2-GRAPHITE COMPACTS(2)

\begin{tabular}{ccc}
\hline $\begin{array}{c}\text { Uranium, } \\
\text { w/o }\end{array}$ & \multicolumn{2}{c}{ Specific Resistance (a) microhm -cm } \\
\cline { 2 - 3 } With the Grain & Across the Grain \\
\hline 0 & 2122 & 3000 \\
2.9 & 2094 & 2912 \\
9.8 & 2243 & 2807 \\
19 & 2466 & 3051 \\
29 & 2485 & 3392 \\
36 & 2787 & 3640 \\
45 & 3194 & 4220 \\
\hline
\end{tabular}

(a) Compact: were ba' ed to $1425 \mathrm{C}$. Room-temperature reslitance data are given. 


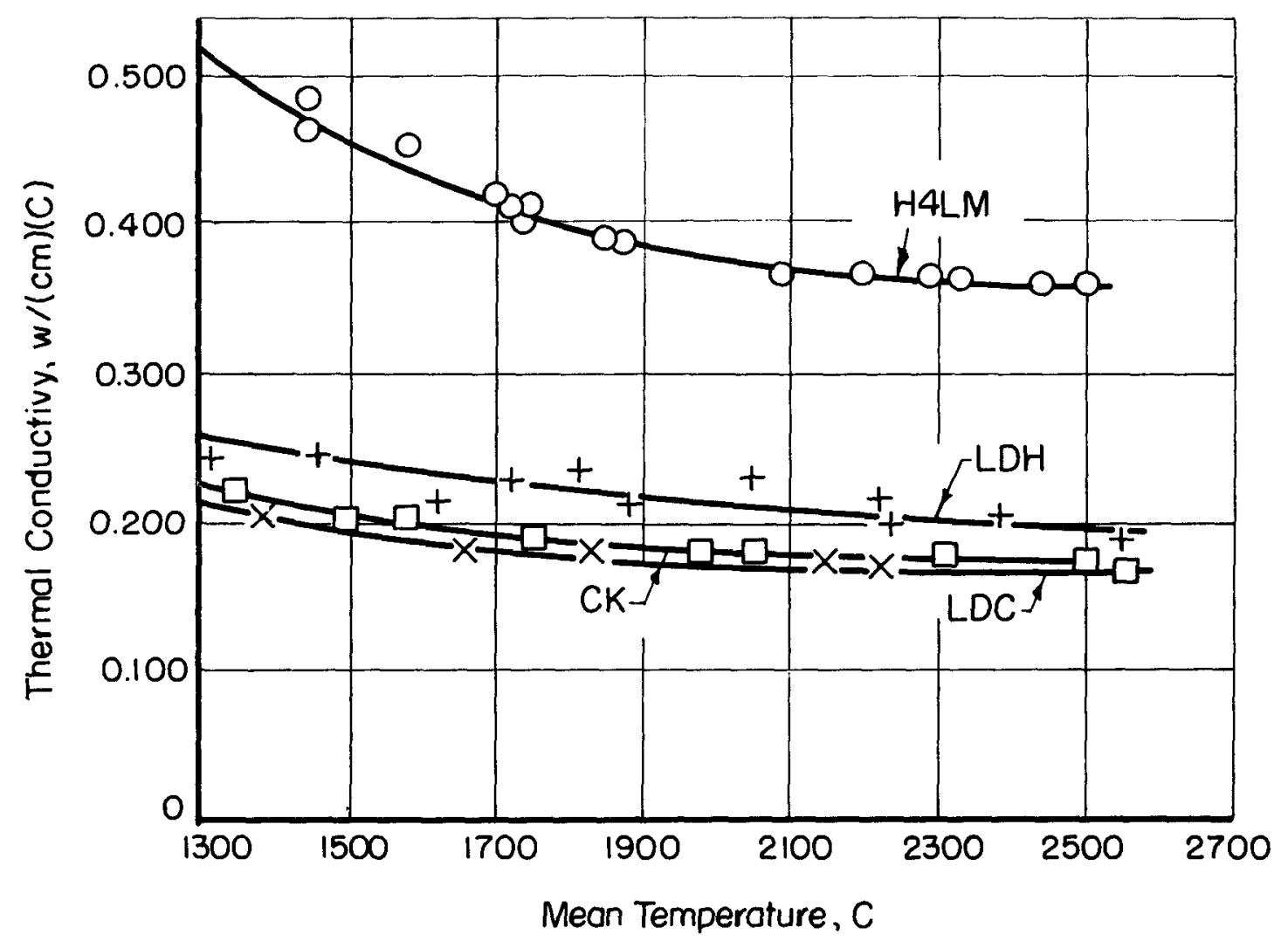

FIGURE D2b. THERMAL CONDUCTIVITY OF GRAPHITE PARALLEL TO GRAIN ${ }^{(4)}$ 
TABLE EIb. ELECTRICAL RESISTIVITY VERSUS FUEL LOADING OF UC 2 -GRAPHITE COMPACTS ${ }^{(2)}$

\begin{tabular}{ccc}
\hline \multirow{2}{*}{$\begin{array}{c}\text { Uranium, } \\
\text { w/o }\end{array}$} & \multicolumn{2}{c}{ Specific Resistance (a), microhm-cm } \\
\cline { 2 - 3 } With the Grain & Across the Grain \\
\hline 0 & 1842 & 2960 \\
10 & 1432 & 1971 \\
20 & 840 & 1736 \\
25 & 782 & 1443 \\
31 & 531 & 892 \\
40 & 437 & 682 \\
50 & 463 & 670 \\
\hline
\end{tabular}

(a) Compacts were baked to 2800 C. Data are for room-temperature resistance.

\section{F1. Reactions with coolants (data are for unfueled graphite)}

a. $\operatorname{Steam}^{(8,9)}$

(1) 2.8 volume per cent $\mathrm{H}_{2} \mathrm{O}$ in helium using "fuel-element graphite":

(a) Minus $6.4 \mathrm{mg}$ per $\mathrm{cm}^{2}$ in $80 \mathrm{hr}$ at $900 \mathrm{C}$

(b) Minus $20 \mathrm{mg}$ per $\mathrm{cm}^{2}$ in $80 \mathrm{hr}$ at $1000 \mathrm{C}$

(2) Varying amounts of $\mathrm{H}_{2} \mathrm{O}$ in helium under gamma irradiation using TSX graphite (9)

$\mathrm{H}_{2} \mathrm{O}$ Concentration,
ppm

50

90

155

300

b. Helium

No data available

c. Carbon dioxide $(10)$

See Table Flc.

$\frac{\text { Weight Loss, } 10^{-7} \mathrm{~g} / \mathrm{g} / \mathrm{hr}}{\text { At } 600 \mathrm{C}}$

2. 18

6. 17

7. 12

5. 29

8. 90

5. 42

10.13 
TABLE F1C. REACTION OF GRAPHITE WITH CARBON DIOXIDE FLOWING AT $1.5 \mathrm{FT}^{3}$ PER HR (10)

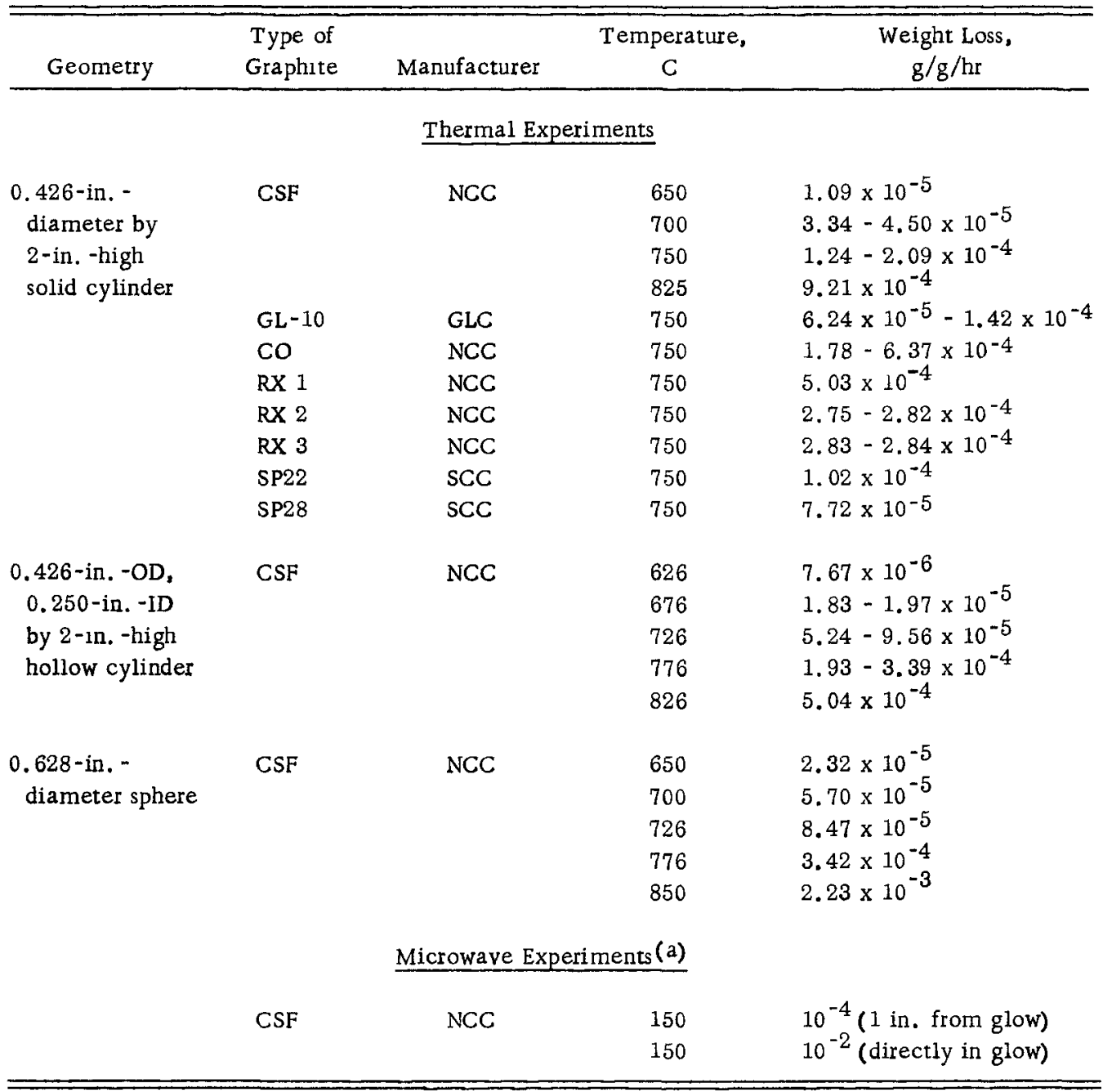

(a) These data are included to indicate possibility of a very rapid reaction at higher temperature and with irradiation. Experiments were conducted at $125 \mathrm{~W}$ at 2450 megacylces in 1.5 -cfh $\mathrm{CO}_{2}$.

d. Nitrogen

No engineering data available

e. Hydrogen

No engineering data available

f. Liquid metals $(11)$

Dilation of TSP graphite parallel to extrusion axis after $500 \mathrm{hr}$, in $650 \mathrm{C}$ sodium was 0.90 per cent. Reaction of graphite with $950 \mathrm{~F}$ sodium during $100 \mathrm{hr}$ was as follows:

\begin{tabular}{lcccc}
$\begin{array}{c}\text { Graphite } \\
\text { Type }\end{array}$ & $\begin{array}{c}\text { Density } \\
\text { g per cm }\end{array}$ & & $\begin{array}{c}\text { Parallel to } \\
\text { Extrusion Axis }\end{array}$ & $\begin{array}{c}\text { Perpendicular to } \\
\text { Extrusion Axis }\end{array}$ \\
\cline { 5 - 5 } SA25 & 1.60 & & 1.40 & 1.46 \\
TSP & 1.70 & & 0.82 & 1.00 \\
CCN & 1.89 & & 0.60 & 0.84
\end{tabular}




\section{g. $\operatorname{Air}(12)$}

The threshold temperature (temperature at which 1 per cent loss occurs in $24 \mathrm{hr}$ in stagnant air) for pure graphite is $540 \mathrm{C}$. At $700 \mathrm{C}$, the los is 1 per cent in 35 min for pure graphite and 1 per cent in 10 min for commercial graphite.

2. Reactions with claddings or structural materials (13)

See Table F2.

TABLE F2. ELEVA TED-TEMPERATURE REACTIONS OF GRAPHITE WITH SOME CLADDING AND STRUCTURAL METALS (13)

\begin{tabular}{|c|c|c|c|c|c|c|c|c|c|}
\hline \multirow[b]{3}{*}{ Metal } & \multicolumn{2}{|c|}{ Exposure } & \multirow{3}{*}{$\frac{\text { Carbon, }}{\text { Before }}$} & \multirow{3}{*}{$\frac{\text { w/o }}{\text { After }}$} & \multirow{2}{*}{\multicolumn{2}{|c|}{$\begin{array}{l}\text { Ultimate } \\
\text { Strength, } \\
1000 \text { ps1 }\end{array}$}} & \multirow{2}{*}{\multicolumn{2}{|c|}{$\begin{array}{l}\text { Elongation, } \\
\text { per cent }\end{array}$}} & \multirow[b]{3}{*}{ Remarks } \\
\hline & \multirow{2}{*}{$\begin{array}{c}\text { Time, } \\
\text { hr }\end{array}$} & \multirow{2}{*}{$\begin{array}{l}\text { Tempera- } \\
\text { ture, F }\end{array}$} & & & & & & & \\
\hline & & & & & Before & After & Before & After & \\
\hline Zirconium & 1000 & 1750 & 0.04 & 0.09 & 70.0 & 70.2 & 44.0 & 8.0 & $\begin{array}{l}\text { Metallographic examination } \\
\text { showed negligible carburization }\end{array}$ \\
\hline Zircaloy-2 & 1000 & 1750 & 0.01 & 0.06 & 101.0 & 89.8 & 28.0 & 22.0 & $\begin{array}{l}\text { Metallographic examination } \\
\text { snowed negligible carburızation }\end{array}$ \\
\hline Zirconium & 1500 & 1850 & 0.04 & 0.40 & 70.0 & 53.0 & 44.0 & 32.0 & $\begin{array}{l}\text { Carburızation case observed, } \\
0.0015-1 n \text {. average, } 0.0023-1 n \text {. } \\
\text { maximum thickness }\end{array}$ \\
\hline $\begin{array}{l}\text { Zirconium } \\
\text { (oxidized surface) }\end{array}$ & 1500 & 1850 & 0.04 & 0.66 & 69.6 & 80.2 & 32.0 & 8.0 & $\begin{array}{l}\text { Carburızation case observed, } \\
0.0015-1 \Pi \text {. average, } 0.0036-1 n \text {. } \\
\text { maxımum thıckness }\end{array}$ \\
\hline $\begin{array}{l}\text { Zirconium } \\
\text { (oxidized surface) }\end{array}$ & 1500 & 1850 & 0.04 & 0.78 & 69.6 & 76.8 & 32.0 & 6.0 & $\begin{array}{l}\text { Carburization case observed, } \\
0.0010-1 n \text {. average, } 0.0013-1 \mathrm{n} \text {. } \\
\text { maximum thickness }\end{array}$ \\
\hline "A"Nıckel & 1500 & 1850 & 0.05 & 0.21 & 67.2 & 55.3 & 37.0 & 36.0 & $\begin{array}{l}\text { Metallographic examination } \\
\text { showed no carburization case or } \\
\text { second-phase carbon } \\
\text { precipitation }\end{array}$ \\
\hline "A"Nickel & 1500 & 1850 & 0.05 & 0.18 & 69.2 & 64.3 & 37.0 & 36.0 & $\begin{array}{l}\text { Metallographic examination } \\
\text { showed no carburization case or } \\
\text { second-phase carbon } \\
\text { precipitation }\end{array}$ \\
\hline "K"Monel & 1500 & 1850 & 0.16 & 0.17 & 99.4 & 89.3 & 44.0 & 52.0 & $\begin{array}{l}\text { Metallographic examination } \\
\text { showed no carburızation case or } \\
\text { second-phase carbon } \\
\text { precipitation }\end{array}$ \\
\hline "K"Monel & 1500 & 1850 & 0.16 & 0.18 & 99.4 & 95.5 & 44.0 & 52.0 & $\begin{array}{l}\text { Metallographic examination } \\
\text { showed no carburization case or } \\
\text { second-phase carbon } \\
\text { pr.cipitation }\end{array}$ \\
\hline
\end{tabular}


DISP.

G1. Dimensional stability during irradiation $(1,14-16)$

a. Investigations defining the dimensional stability of a fueled graphite as a function of fission-fragment exposure, irradiation temperature, and fuelparticle type and size have not been published.

b. General Atomic has published high-burnup data for graphite fueled with $(\mathrm{Th}, \mathrm{U}) \mathrm{C}_{2}(6.5 \mathrm{w} / \mathrm{O}$ uranium, $15.5 \mathrm{w} / \mathrm{o}$ thorium). These elements experienced a burnup equal to about 60 per cent of the HTGR design lifetime of 3 years, or $6.9 \times 10^{19}$ fissions per $\mathrm{cm}^{3}$. Dimensional stability of these is given in Table Glb. Increased matrix change produced by the greater fission-fragment damage to fuel of smaller particle size is evident.

TABLE G1b. DIMENSIONAL CHANGES OF FUEL COMPACTS IRRADIATED TO $6.9 \times 10^{19}$ FISSIONS PER $\mathrm{CM}^{3}(15)$

\begin{tabular}{cccccc}
\hline \hline & $\begin{array}{c}\text { Fuel- } \\
\text { Particle } \\
\text { Size, }\end{array}$ & $\begin{array}{c}\text { Average Tempera- } \\
\text { ture of Graphite } \\
\text { Compact }\end{array}$ & $\mu$ & $\begin{array}{c}\text { Fuel-Body } \\
\text { Center-Line Tempera } \\
\text { ture, Calculated C }\end{array}$ & $\begin{array}{c}\text { Dimensional Changes, } \\
\text { per cent }\end{array}$ \\
\hline \multirow{2}{*}{1} & $250-500$ & $650-760$ & 1200 & 0 & Diameter \\
2 & $110-250$ & $730-840$ & 1300 & -0.2 & +0.2 \\
3 & $<j 0$ & $840-900$ & 1400 & -1.7 & +0.2 \\
4 & $<50$ & $900-925$ & 1480 & -2.2 & +2.2 \\
5 & $110-250$ & $760-840$ & 1200 & -0.3 & $<-0.1$ \\
6 & $250-500$ & $700-790$ & 1150 & 0 & $<+0.1$ \\
\hline \hline
\end{tabular}

c. Data by ORNL ${ }^{(14)}$ for similar fission levels but for different graphite matrices, fuels, and temperatures indicate greater dimensional change. Graphite compacts $(1,16)$ containing $9.55 \mathrm{w} / \mathrm{o}$ uranium and baked to $2800 \mathrm{C}$ were irradiated with a central fuel temperature of approximately $1850 \mathrm{C}$, dropping to a can-wall temperature of approximately $850 \mathrm{C}$. Burnup was $5.05 \times 10^{19}$ fissions per $\mathrm{cm}^{3}$. Dimensional changes of the specimens were -3.1 to -4.2 per cent on diameter, and +2.7 to +5.2 on length, or a bulk density change of +2.5 per cent.

\section{Fission-gas-release data(17-19)}

a. Fission-gas release from fueled graphite is dependent upon dispersedfuel form (and particle size), temperature, and the physical properties of the matrix graphite.

b. Extensive data on xenon and krypton release from ( $U, T h) C_{2}-g$ raphite fue1 compacts have been reported by General Atomic. The steady-state release of these gases as a function of temperature and half-life were determined in out-of-pile photofissioning experiments. The results(17) are shown in Figures $G 2 b(1)$ and $G 2 b(2)$. Xenon-release data have also been obtained during heating of preirradiated fueled graphite. (18) Figure G2b(3) presents release data from fuel-impregnated graphite. Figure G2b(4) gives release from fueled elements prepared by different methods containing ( $\mathrm{Th}, \mathrm{U}) \mathrm{C}_{2}$ fuel. Release was obtained for broken as well as whole 


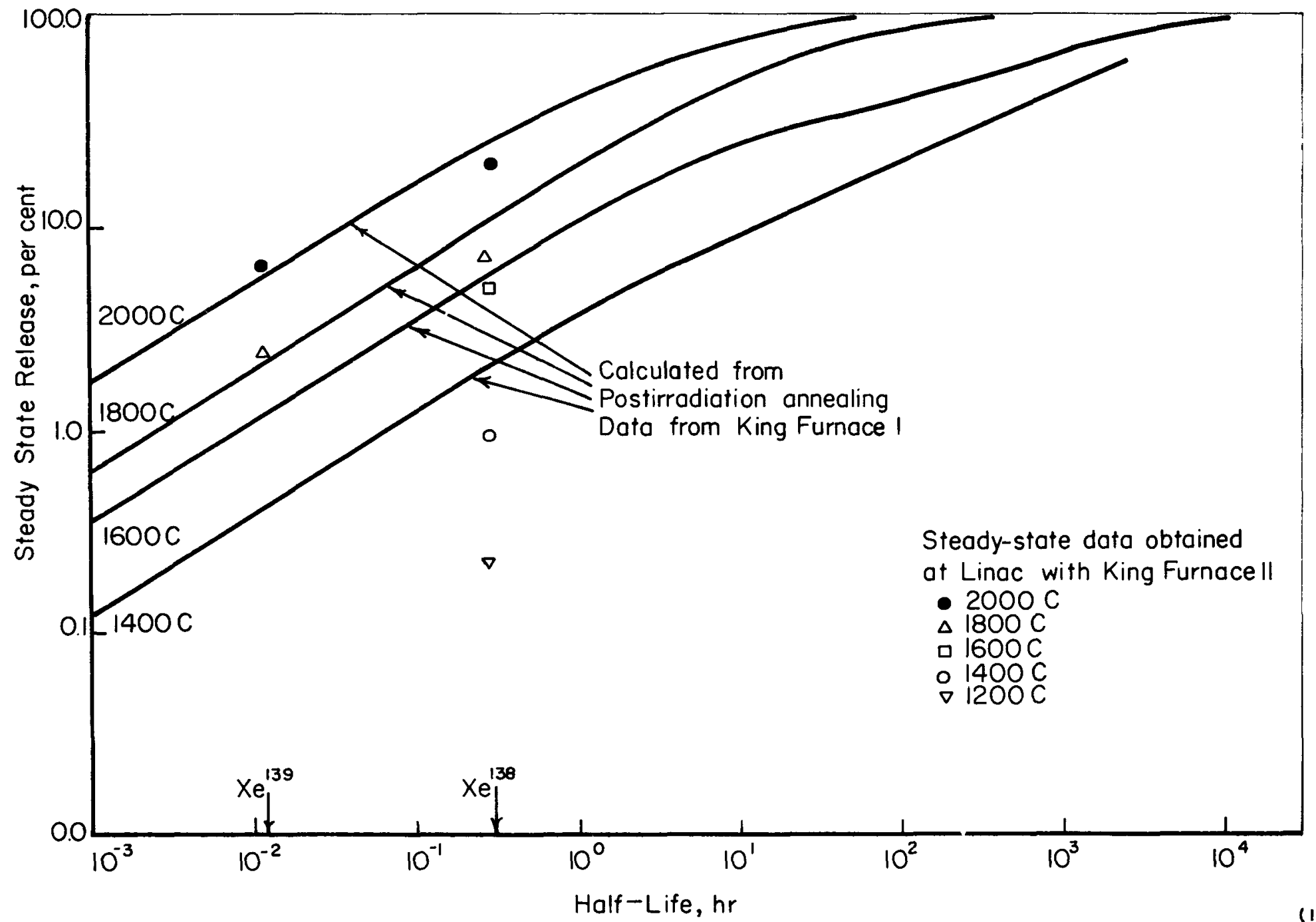

FIGURE G2b(1). XENON RELEASE FROM UNCOATED (U,Th) $C_{2}$ PARTICLES IN GRAPHITE-MATRIX FUEL BODIES ${ }^{(17)}$ 


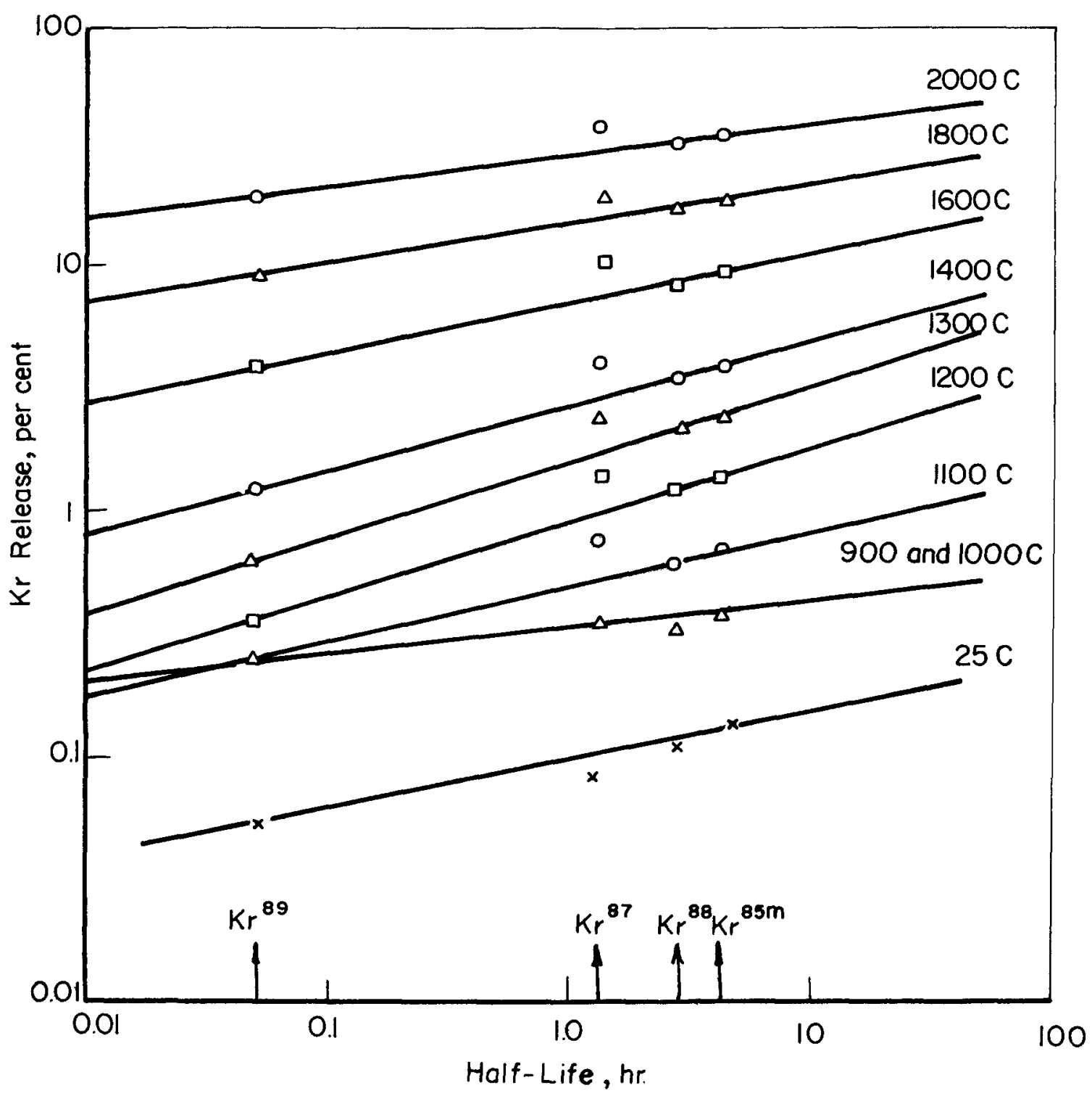

FIGURE G2b(2). STEADY STATE KRYPTON RELEASE FROM UNCOATED CARBIDE PARTICLES IN GRAPHITE - MATRIX FUEL BODIES ${ }^{(17)}$ 


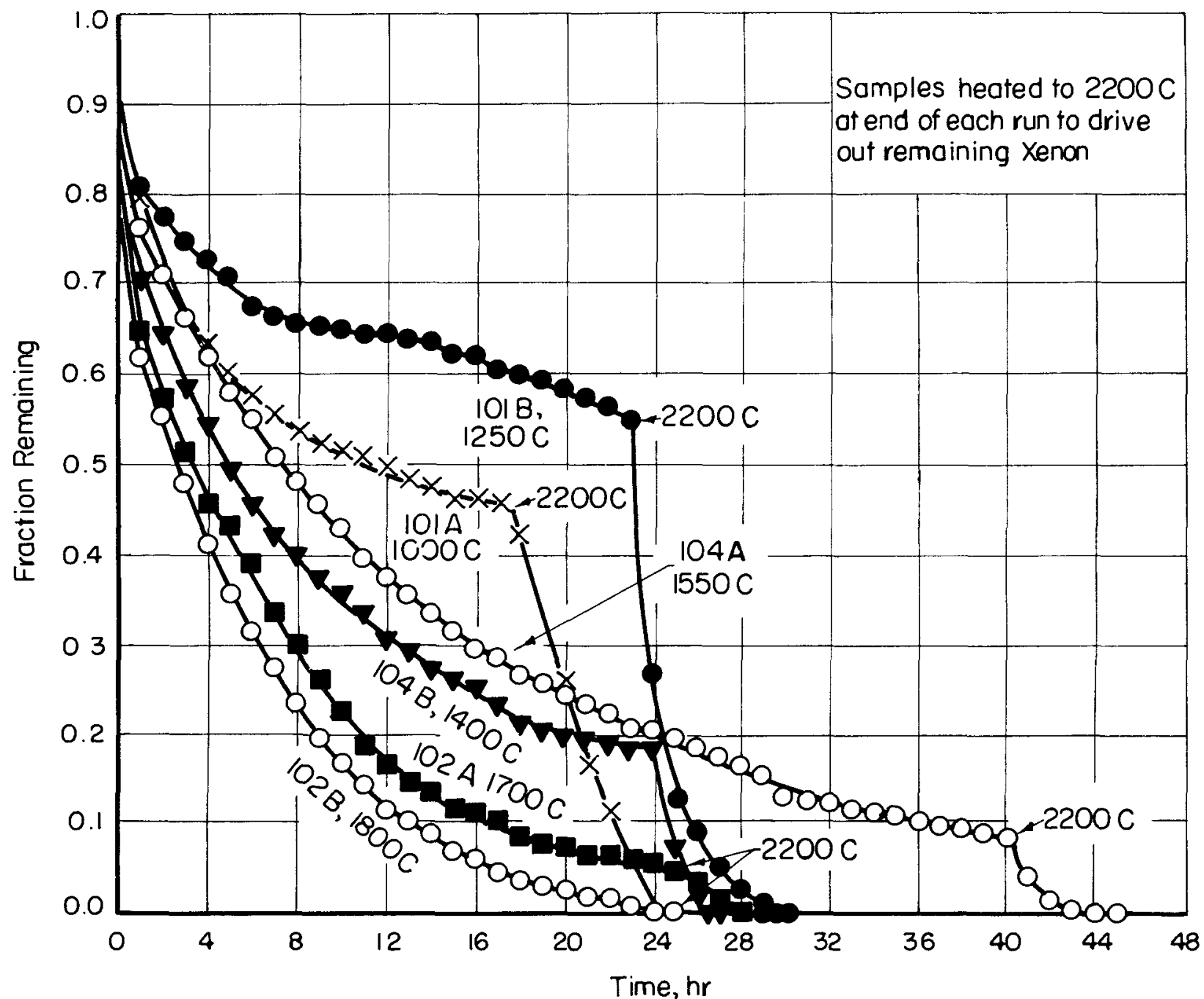

FIGURE G2b(3). Xe ${ }^{133}$ RELEASE FROM TURRET-TYPE UO 2 - IMPREGNATED COMPACTS AT VARIOUS TEMPERATURES ${ }^{(18)}$ 


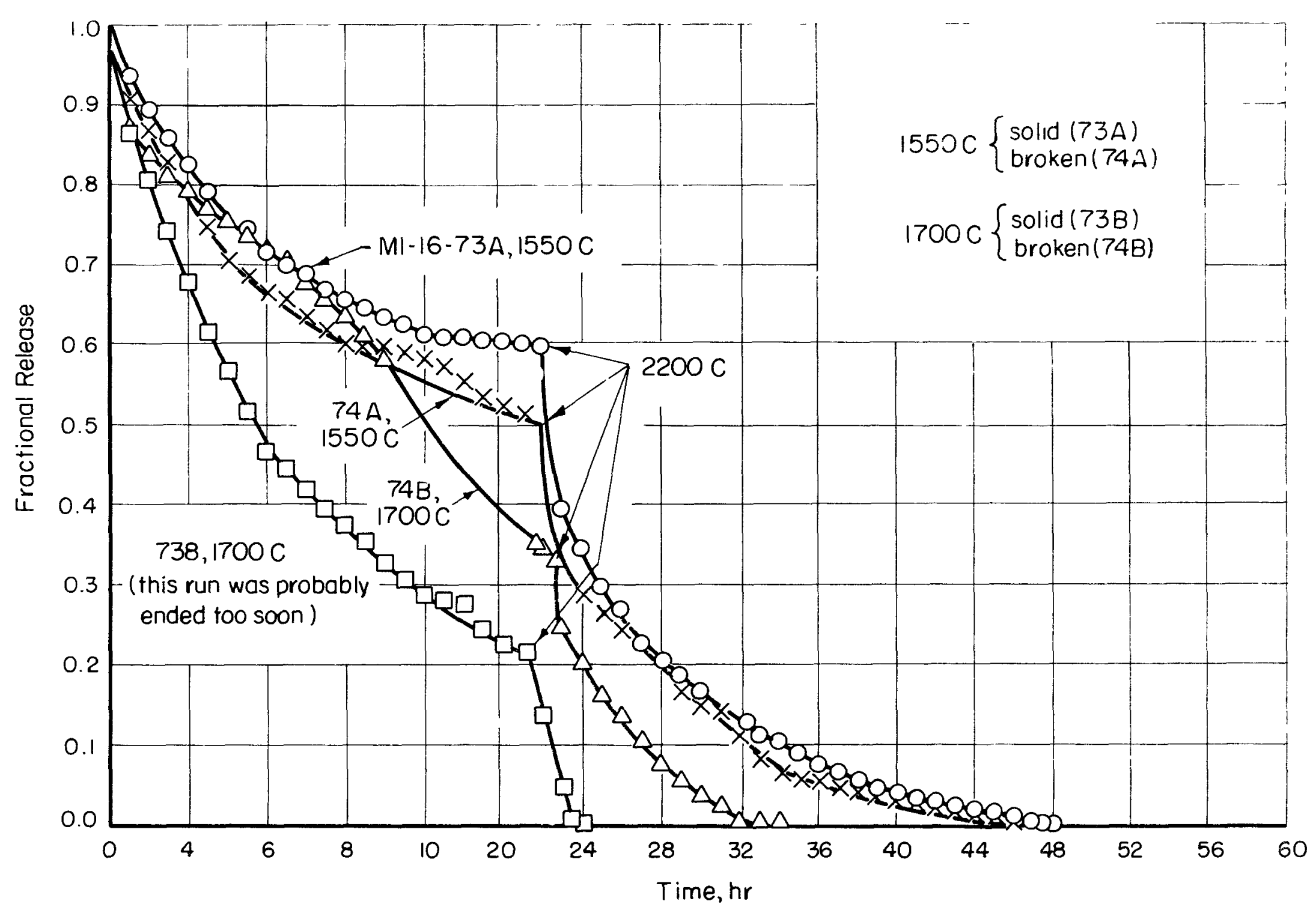

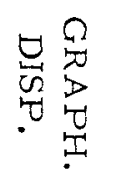

FIGURE G2b (4) XENON RELEASE FROM SOLID AND BROKEN FUEL COMPACTS AT 1550 AND $1700 C^{(18)}$ 
specimens to determine the effect of specirnen size on release. No explanation was presented for the anomalous result of Specimen 74B (broken). Investigations by Cubicciotti $(19)$ hav indicated that the rate of xenon escape is independent of fueled-graphite sample size.

\section{Unusual nuclear properties}

No data available

\section{Property changes as a result of irradiation}

a. Durand, et al. ,(20) and Hunter ${ }^{(21)}$ have determined in-pile changes of the thermal conductivities of uranium-impregnated graphite as a function of exposure and temperature. Hunter found a ratio of $\mathrm{K}_{\mathrm{O}} / \mathrm{K}$, where $\mathrm{K}_{\mathrm{O}}$ is the preirradiation thermal conductivity, as high as 39 after an exposure of $6.3 \times 10^{21}$ fissions per $\mathrm{cm}^{3}$ at $780 \mathrm{C}$. Durand, et al., found less severe decreases in thermal conductivity at a comparable temperature and a ratio of $\mathrm{K}_{\mathrm{O}} / \mathrm{K}$ of only 1.3 after an exposure of $9.2 \times 102 \mathrm{l}$ fissions per $\mathrm{cm}^{3}$ at $1300 \mathrm{C}$. Figure G5a, from Durand et al. ,(20) compares data obtained by Hunter, Durand, et al. and Heterick et al.

b. The changes in properties of fueled graphites depend upon the percentage of fission fragments recoiling into the matrix, as well as upon temperature of irradiation and fuel burnup. Theoretical treatments $(22)$ of the effect of fuel-particle size on fission-fragment damage have indicated that at a particle diameter of $100 \mu$ the damage would be less than 5 per cent of the homogeneous case. Experimental studies $(23,24)$ of radiation damage as a function of $\mathrm{UO}_{2}$ fuel-particle size have been reported.

Figure G5b illustrates the relative changes in electrical resistivity found for different $\mathrm{UO}_{2}$ particle sizes after an integrated flux of 1.8 to $1.9 \mathrm{x}$ $1018 \mathrm{nvt}$ at maximum temperatures of 66 to $88 \mathrm{C}$ and after pulse annealing for $1 \mathrm{hr}$ at successive $25 \mathrm{C}$ intervals. (5). A subsequent anneal of these specimens at $425 \mathrm{C}$ for $18 \mathrm{hr}$ had little further effect on the resistivity. An additional $12-\mathrm{hr}$ anneal at $725 \mathrm{C}$ lowered the resistivity slightly.

\section{H. References}

(1) National Carbon Company, "Summary Report - Phase II, GraphiteMatrix Nuclear Fuel Elements", Newsletter No. 3, pp 54, 56, 66 (October 31, 1960).

(2) National Carbon Company, "Summary Report - Phase I, GraphiteMatrix Nuclear Fuel Elements", ORO-240, Vol. l (December 22, 1959), p 70 .

(3) "Gas-Cooled Reactor Project Quarterly Progress Report", ORNL-3015 (November 11, 1960), p 75.

(4) Wagner, P., Driesner, A. R., and Kmetko, E. A., "Some Mechanical Properties of Graphite In the Temperature Range 20 to $3000^{\circ} \mathrm{C}$ ", Proceedings of the Second United Nations International Conference on the Peaceful Uses of Atomic Energy, Geneva (1958), A/Conf. 15/P/702, Vol. 7, 379 . 


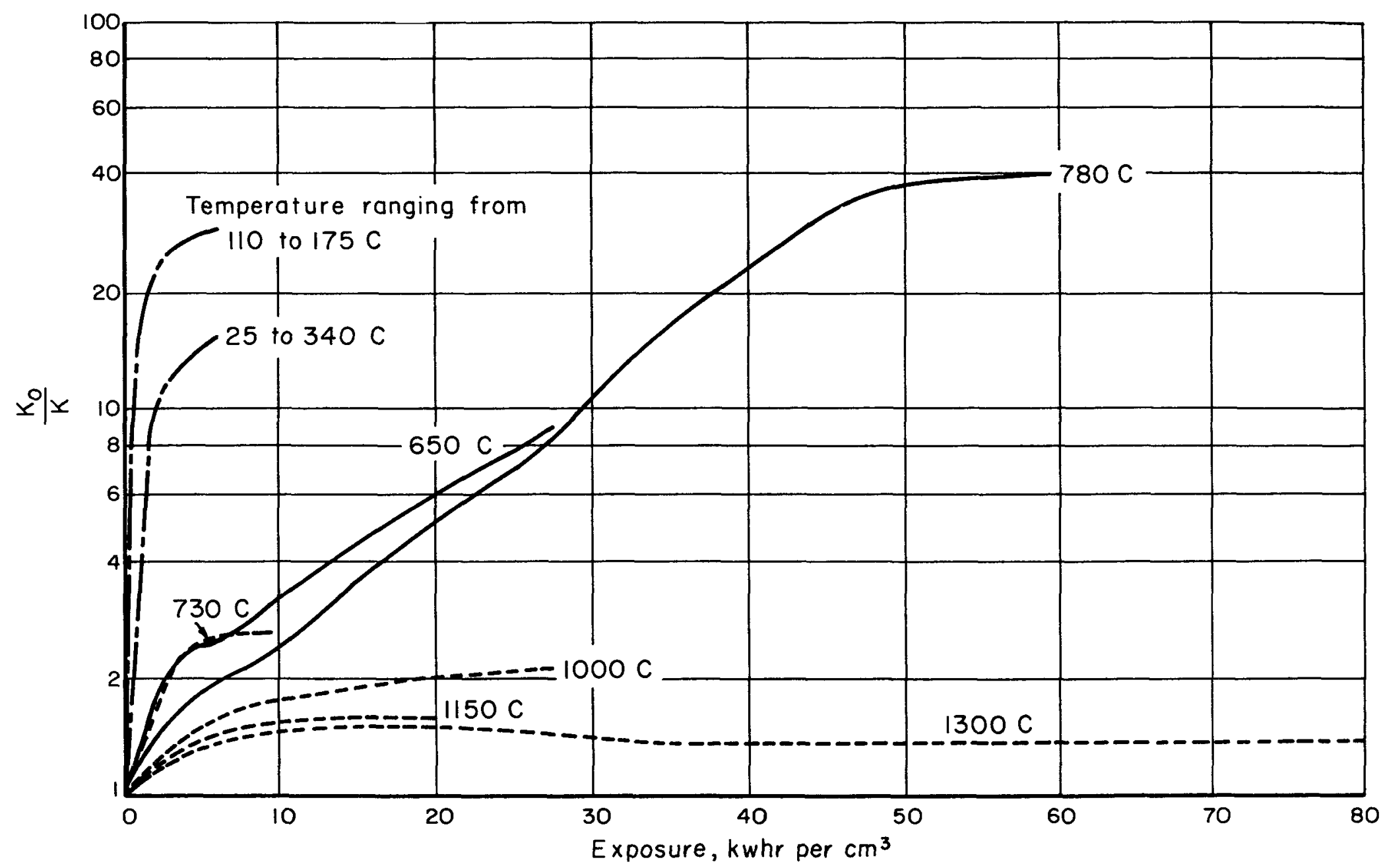

FIGURE G5Q. IN-PILE THERMAL CONDUCTIVITY OF URANIUM-IMPREGNATED GRAPHITE AS MEASURED BY VARIOUS INVESTIGATORS AT DIFFERENT TEMPERATURE (20) 


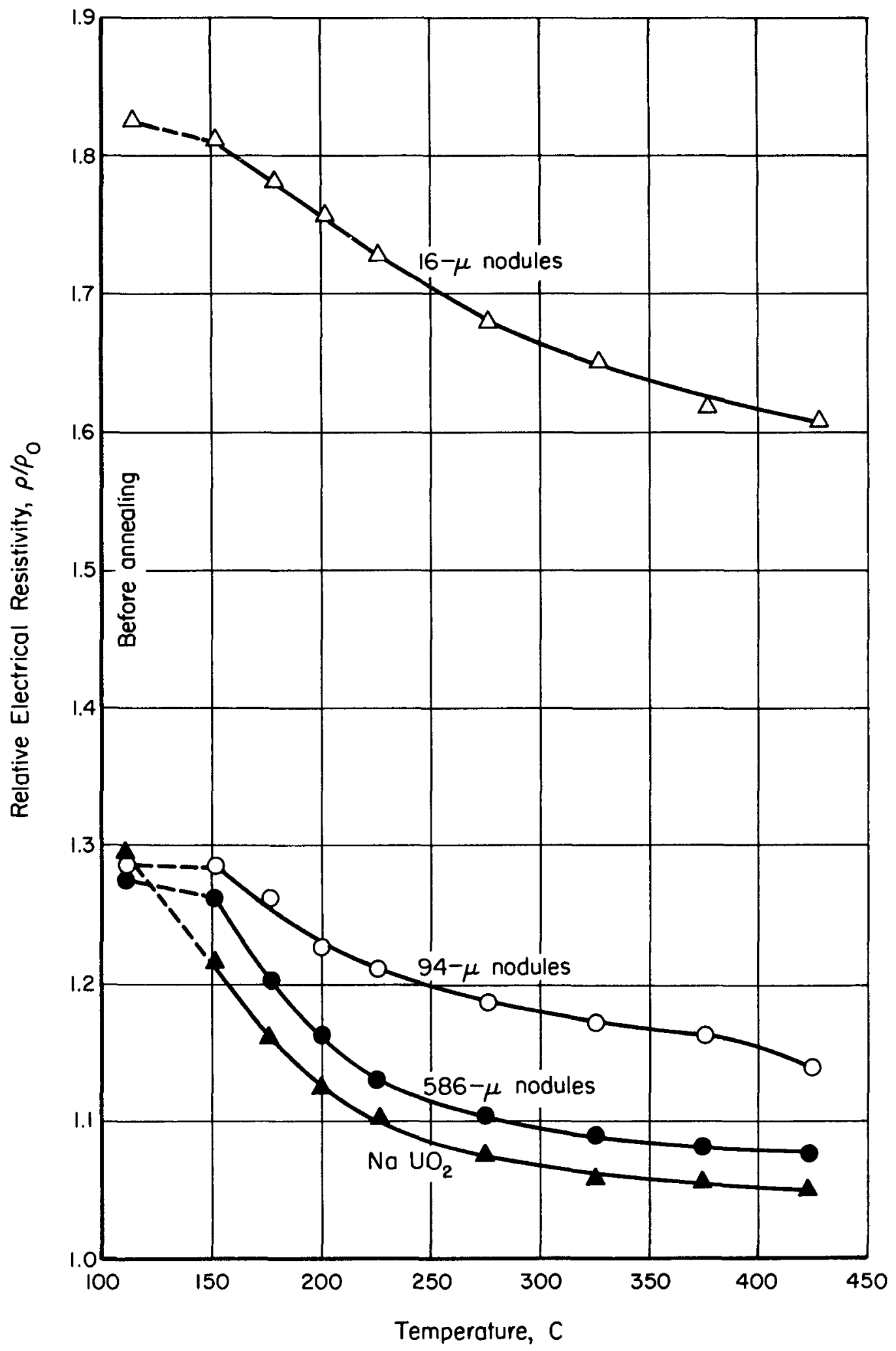

FIGURE G5b RADIATION-DAMAGE ANNEALING IN UO ${ }_{2}$-GRAPHITE BODIES ${ }^{(5)}$ 
(5) Eatherly, W. P., Janes, M., Mansfield, R. L. , Bourdeau, R. A. , and Meyer, R. A. , "Physical Properties of Graphite Materials for Special Nuclear Applications", Proceedings of the Second United Nations International Conference on the Peaceful Uses of Atomic Energy, Geneva (1958), A/Conf. 15/P/708, Vol. 7, p 389.

(6) Green, L., Jr., Stehsel, M. L., and Waller, C. E., "Measurements of Mechanical Properties of Pure and Uranium-Loaded Graphites at Elevated Temperatures", AGC-1537 (December 23, 1958).

(7) Handwerk, J. H., and Lied, R. C. , "The Manufacture of the GraphiteUrania Fuel Matrix for TREAT", ANL-5963 (January, 1960), p 21.

(8) Zumwalt, L. R., Burnette, R. D., and Riedinger, A. B., "Carbon Transport and Corrosion in High-Temperature Gas-Cooled Reactors", GA-2630 (April 12, 1962).

(9) Albaugh, F. W., "Reactor and Fuels Research and Development Operation", HW-72590A (January, 1962), p A38 (unclassified section).

(10) Clark, T. J., "Thermal and Microwave Oxidation of Various ReactorGrade Graphites", TID-7597 (March 3, 1961), pp 207-228.

(11) Gill, J. J., "Sodium-Graphite Interactions and Graphite Protective Coating s", NAA-SR-6094 (May 1, 1961).

(12) Loch, L. D. , "Graphite", Reactor Handbook, Vol I, Materials, 2nd Edition, Interscience Publishers, Inc., New York (1960), pp 893-894.

(13) Carpenter, R., and Del Grosso, A., "Army Gas-Cooled Reactor Systems Program Summary Report on Materials for the GCRE-II", IDO-28564 (December 30, 1960), p 54.

(14) "Gas-Cooled Reactor Project Quarterly Progress Report", ORNL-3102 (May 26, 1961), p 177-178.

(15) Goeddel, W. V., "The Development And Evaluation of Graphite-Matrix Fuel Compacts for the HTGR", GA-2289 (August 8, 1961).

(16) Morgan, J. G. , "Irradiation Effects on $\mathrm{UC}_{2}$ Dispersed in Graphite (ORNL-MTR-48-1), Interim Report No. 1. , CF-60-6-78 (August 18, 1960).

(17) Anderson, E. E., "Steady-State Release Function of Krypton and Xenon Fission Products at High Temperatures From ( $U, T h) C_{2}-G r a p h i t e ~ F u e l$ Matrix In Out-of-Pile Experiments, GA-3211 (June 15, 1962).

(18) "40-MW(E) Prototype High-Temperature Gas-Cooled Reactor Research and Development Program, Quarterly Progress Report for Period Ending September 30, 1960", GA-1774 (September 30, 1960). 
(19) Cubicciotti, D., "The Diffusion of Xenon From Uranium-Carbide Impregnated Graphite at High Temperatures", NAA-SR-194 (October 13, 1952).

(20) Durand, R. E. , Klein, D. J., and Nykiel, F. R., "Effect of Reactor Irradiation on the Thermal Conductivity of Uranium Impregnated Graphite at Elevated Temperatures", NAA-SR-836 (August 15, 1954).

(21) Hunter, L. P., "Effect of Fission Recoil Fragments on the Thermal Conductivity of Graphite", J. Appl. Phys., 30 (12), (December, 1959).

(22) Faris, F. E., "Uranium-Bearing Graphite for Fuel Elements", TID2004, Reactor Sci. Technol. , 2(4), 95-112 (1952).

(23) Loch, L. D., Slyh, J. A , and Duckworth, W H., "Studies of Graphite for Fuel Elements", BMI-954 (October 13, 1954).

(24) Kernohan, R. H., "Effect of Fissionable Particle Size on Fission Damage in Graphite", ORNL 1722 (July 14, 1954). 
DISP.

\section{STAINLESS STEEL-UO 2 DISPERSION FUEL}

Compiled by D. L. Keller and D. L. Stoltz

\section{A1. Chemical composition}

Stainless steel- $\mathrm{UO}_{2}$ dispersion fuels containing 10 to $50 \mathrm{w} / \mathrm{o} \mathrm{UO}_{2}$ in the core have been fabricated successfully. Even higher loadings can be prepared but these are most generally called "cermet" fuels.

2. Phase diagram

Phase diagrams of the particular stainless steel and $\mathrm{UO}_{2}$ are not applicable since little or no reaction occurs between constituents.

\section{Effect of impurities}

The effect of impurities on stainless steel is well known, so high-quality commercial steel powders are used in fuel fabrication. The total impurity level of the $\mathrm{UO}_{2}$ should be maintained below $500 \mathrm{ppm}$ to avoid harmful contamination of the matrix. Most important is avoidance of oxygen pickup by the stainless steel and this is achieved by using a $\mathrm{UO}_{2}$ very low in "excess" oxygen content.

B1. Density (room temperature)

Density of $\mathrm{UO}_{2} \mathrm{x}$ volume per cent $\mathrm{UO}_{2}+$ density of stainless steel $\mathrm{x}$ volume per cent stainless steel = density of dispersion.

\section{Uranium content}

$0.881 \times \mathrm{w} / \mathrm{o} \mathrm{UO}_{2} \mathrm{x}$ density = uranium content of dispersion (see Fuel Comparison Table).

7. Thermal expansion (linear) (1)

The mean linear-thermal-expansion coefficients have been measured for various $\mathrm{UO}_{2}$-stainless steel dispersions clad with stainless steel. In Table B7, the the rmal-coefficient of expansion of various fuel plates is compared to commercial Type 318 stainless steel.

TABLE B7. THERMAL-EXPANSION DATA FOR STAINLESS STEEL AND FOR STAINLESS STEEL-UO ${ }_{2}$ DISPERSION FUEL PLATES( 1 )

\begin{tabular}{|c|c|}
\hline Material & $\begin{array}{c}\text { Mean Coefficient of Thermal } \\
\text { Expansion }(20-925 \mathrm{C}) \\
10^{-6} \text { per } \mathrm{C} \\
\end{array}$ \\
\hline Commercial Type 318 stainless steel & 10.7 \\
\hline $\begin{array}{l}\text { Fuel plate: } 31-\mathrm{mil} 25 \mathrm{w} / \mathrm{o} \mathrm{UO}_{2} \text { prealloyed Type } 318 \\
\text { stainless core, } 7-\mathrm{mil} \text { Type } 318 \text { stainless cladding }\end{array}$ & 10.7 \\
\hline 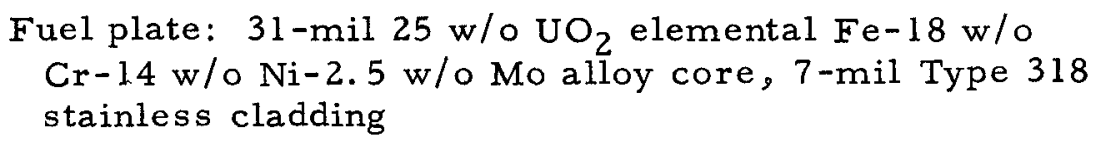 & 11.0 \\
\hline
\end{tabular}


8. Recrystallization temperature range

Effective recrystallization temperature of stainless steel matrix is raised due to interference of $\mathrm{UO}_{2}$ particles.

C1. Hardness (room temperature)

The hardness of a $30 \mathrm{w} / 0 \mathrm{UO}_{2}$-Type 316 stainless steel dispersion ranged from 81-90 Rockwell $\mathrm{B}$. These values were dependent upon the type of $\mathrm{UO}_{2}$ particles used and the density reached.

\section{3\&4. Ultimate tensile strength and yield strength ${ }^{(2)}$}

Ultimate tensile strength, yield strength, and elongation of dispersions having various loadings of $\mathrm{UO}_{2}$ in Type 316 stainless steel-matrix core materials are listed in Table C3. These cores have been cold pressed, sintered, and coined, and the values given are based on an average of samples. When these core materials a re clad with stainless steel and fabricated into fuel plates, the cores are elongated extensively. During the fabrication, new variables are introduced which effect the ultimate tensile strength. The most useful measure of strength for these fuel plates is the transverse tensile strength. In this test, the tensile stresses are applied perpendicular to the rolling plane and do not involve the cladding. Table C4 contains ultimate transverse tensile-strength values for various $\mathrm{w} / \mathrm{o} \mathrm{UO}_{2}-$ stainless steel matrix dispersions.

5. Compressive strength

No data available

6. Creep strength $(3)$

Fuel plates with $25 \mathrm{w} / \circ \mathrm{UO}_{2}$ in both elemental 18-14-2.5 alloy and prealloyed Type 318 stainless steel matrices have been fabricated by optimum fabrication techniques and have had creep-rupture tests performed at $900 \mathrm{C}$. Figure C6 summarizes these data.

7. Young's modulus

No data available

8. Shear modulus

No data available

9. Bulk modulus

No data available

10. Poisson's ratio

No data available

11. Elongation

See Table C3.

D2. Thermal conductivity (4)

See Figure D2. 
TABLE C3. MECHANICAL PROPERTIES OF SOME UO ${ }_{2}$-TYPE 316 STAINLESS STEEL DISPERSIONS( ${ }^{(1)}$

\begin{tabular}{|c|c|c|c|c|c|c|c|}
\hline \multirow[b]{2}{*}{$\begin{array}{l}\mathrm{UO}_{2} \\
\mathrm{w} / \mathrm{o}\end{array}$} & \multirow[b]{2}{*}{$\begin{array}{l}\text { Density, } \\
\text { per cent of } \\
\text { theoretical }\end{array}$} & \multicolumn{3}{|c|}{ Room-Temperature Values } & \multicolumn{3}{|c|}{ Values at $1600 \mathrm{~F}$} \\
\hline & & $\begin{array}{l}\text { Ultimate } \\
\text { Strength, } \\
\text { psi }\end{array}$ & $\begin{array}{l}0.2 \text { Per Cent } \\
\text { Offset Yield } \\
\text { Strength, psi }\end{array}$ & $\begin{array}{l}\text { Elongation } \\
\text { in } 1 \text { In. , } \\
\text { per cent }\end{array}$ & $\begin{array}{l}\text { Ultimate } \\
\text { Strength, } \\
\text { psi }\end{array}$ & $\begin{array}{l}0.2 \text { Per Cent } \\
\text { Offset Yield } \\
\text { Strength, psi }\end{array}$ & $\begin{array}{l}\text { Elongation } \\
\text { in } 1 \mathrm{In.}, \\
\text { per cent }\end{array}$ \\
\hline 25 & 98 & 46,700 & 31,800 & 10 & 12,400 & 11,400 & 14 \\
\hline 30 & 96.2 & 43,200 & 31,800 & 6 & 14,400 & 13,700 & 9 \\
\hline 30.64 & 96.5 & 43,400 & 29,600 & 7 & 13,500 & 12,300 & 8 \\
\hline 35 & 96.6 & 37,700 & 29,800 & 6 & 12,900 & 12,100 & 5 \\
\hline
\end{tabular}

TABLE C4. ULTIMATE TRANSVERSE TENSILE STRENGTHS OF VARIOUS UO 2 STAINLESS STEEL MATRLX DISPERSIONS(2)

\begin{tabular}{|c|c|c|c|c|c|}
\hline $\begin{array}{l}\mathrm{UO}_{2} \\
\mathrm{w} / \mathrm{O}\end{array}$ & $\begin{array}{c}\text { Fuel } \\
\text { Matrix }\end{array}$ & $\begin{array}{l}\text { Ultimate Transverse } \\
\text { Tensile Strength, psi }\end{array}$ & $\begin{array}{l}\mathrm{UO}_{2} \\
\mathrm{w} / \mathrm{O}\end{array}$ & $\begin{array}{c}\text { Fuel } \\
\text { Matrix }\end{array}$ & $\begin{array}{l}\text { Ultimate Transverse } \\
\text { Tensile Strength, psi }\end{array}$ \\
\hline 20 & Iron & 33,500 & 37 & $\begin{array}{l}\text { Austenitic } \\
\text { stainless }\end{array}$ & 14,500 \\
\hline 25 & Iron & 28,500 & & & \\
\hline 30 & $\begin{array}{r}\text { Austenitic } \\
\text { stainless }\end{array}$ & $26,000(a)$ & 40 & $\begin{array}{r}\text { Austenitic } \\
\text { stainless }\end{array}$ & 11,000 \\
\hline \multirow[t]{2}{*}{35} & $\begin{array}{r}\text { Austenitic } \\
\text { stainless }\end{array}$ & 16,000 & 45 & $\begin{array}{r}\text { Austenitic } \\
\text { stainless }\end{array}$ & 8,000 \\
\hline & & & 50 & $\begin{array}{r}\text { Austenitic } \\
\text { stainless }\end{array}$ & 4,000 \\
\hline
\end{tabular}

(a) Elevated-temperature values for austenitic stainless $-30 \mathrm{w} / \mathrm{o} \mathrm{UO}_{2}$ dispersions:

Temperature, C Ultimate Strength, psi

$\begin{array}{lr}531 & 13,000 \\ 641 & 12,000 \\ 760 & 8,500\end{array}$




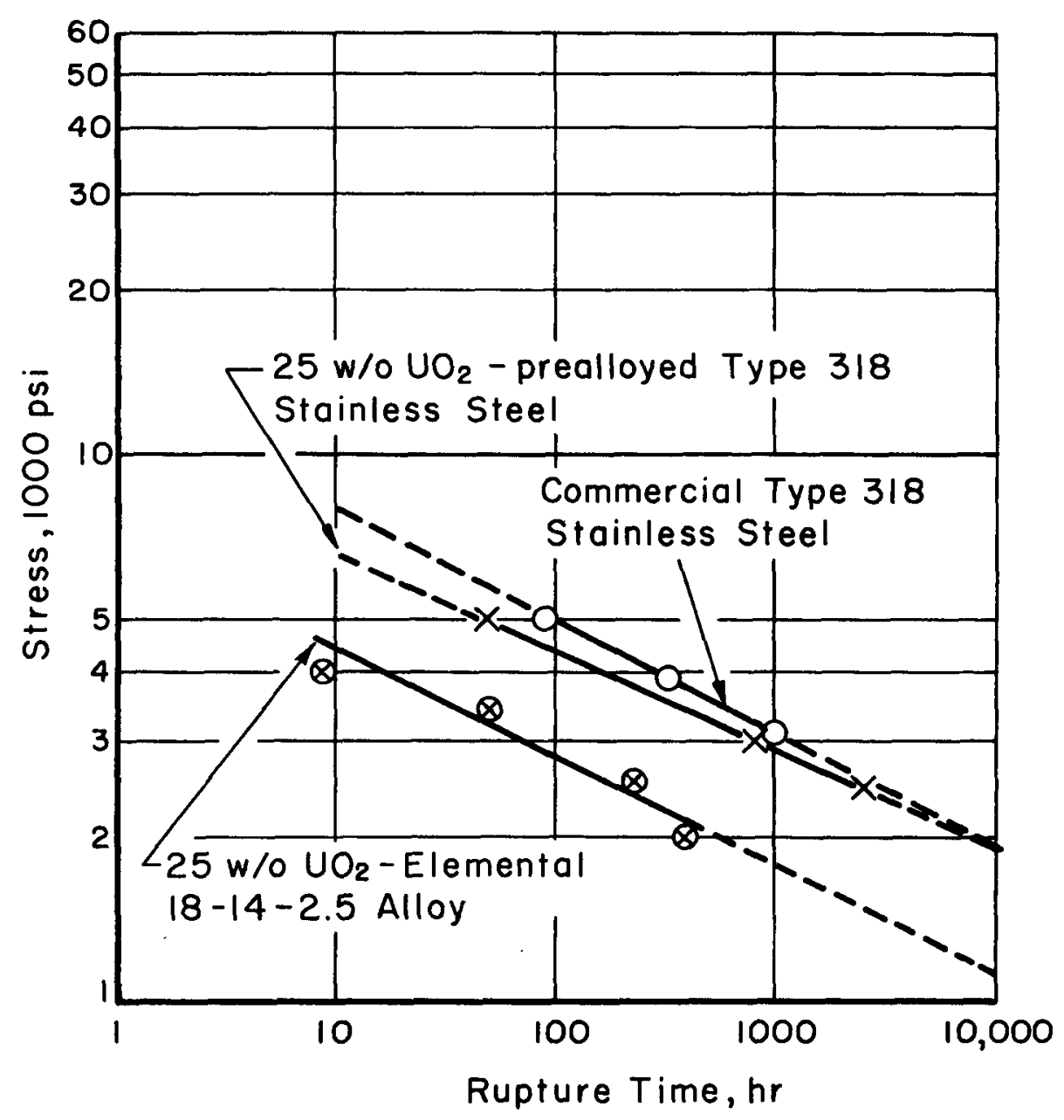

FIGURE C6. COMPARISON OF STRESS-RUPTURE CURVES OF $\mathrm{UO}_{2}$ - STAINLESS STEEL FUEL PLATES WITH COMMERCIAL SHEET AT $900 \mathrm{C}^{(3)}$ 


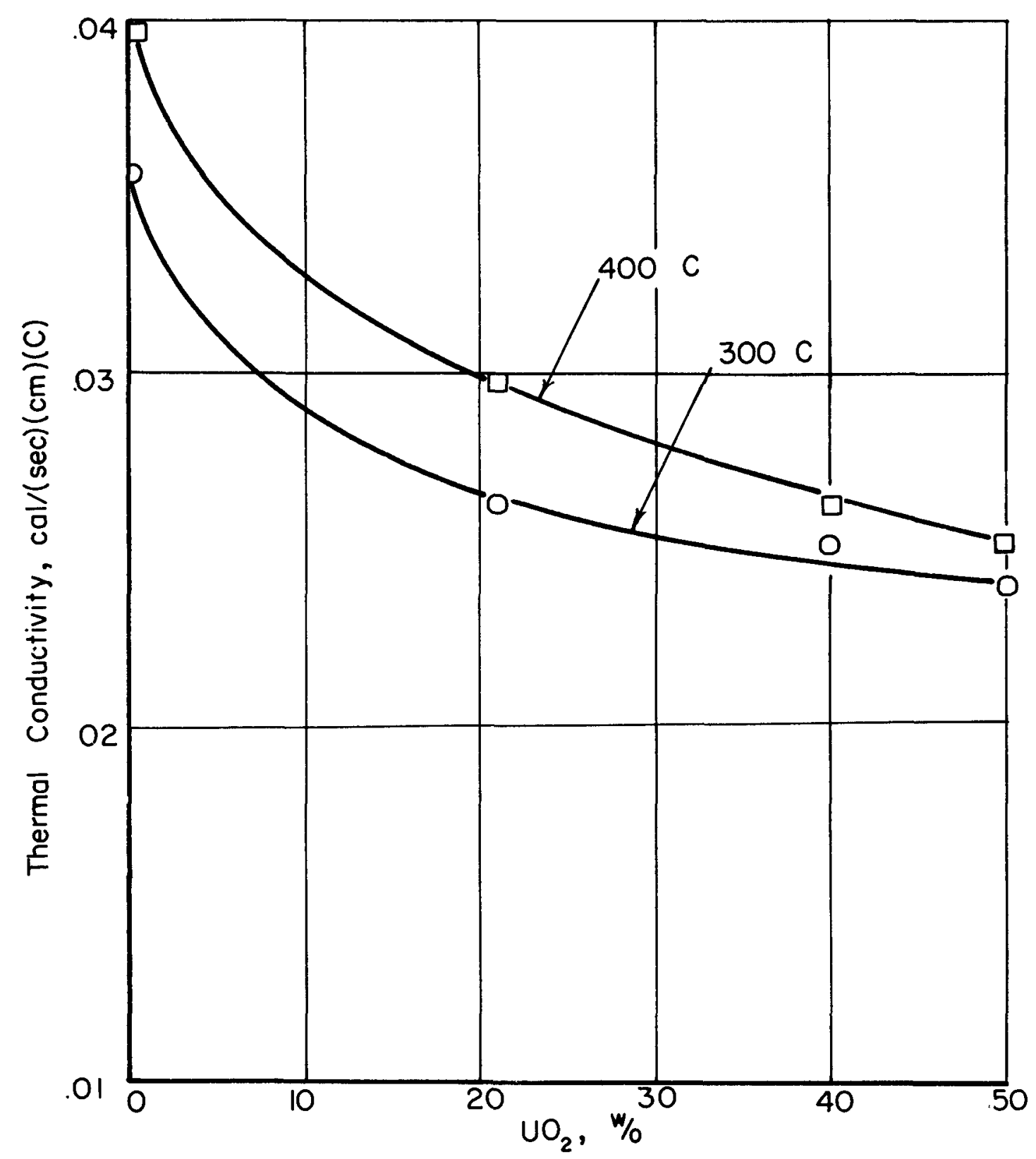

FIGURE D2. THERMAL CONDUCTIVITY FOR UO $\mathrm{U}_{2}$ - STAINLESS STEEL ${ }^{(4)}$ 
E1. Electrical resistivity $(5)$

A fuel plate consisting of a $12-\mathrm{mil} 30 \mathrm{w} / \mathrm{o} \mathrm{UO}_{2}$-elemental iron-18 w/o chromium-9 w/o nickel alloy core, and a 4-mil Type 347 stainless steel cladding has an electrical-resistivity value of $96.52 \mathrm{microhm}-\mathrm{cm}$ at $30 \mathrm{C}$.

F. Chemical properties $(1)$

a. The corrosion resistance of $\mathrm{UO}_{2}$-stainless steel dispersions is greatly affected by the distribution of the $\mathrm{UO}_{2}$ in the stainless steel matrix. Thus, if the fuel particles are dispersed uniformly in a continuous matrix of highly corrosion resistant material, a pinhole defect in the fuel plate's cladding would only result in a few $\mathrm{UO}_{2}$ particles being attacked by the corrosive coolant.

b. Complete corrosion data are not available, but loadings of 25 and $30 \mathrm{w} / \mathrm{o}$ $\mathrm{UO}_{2}$ in matrices of Types 347, 302, 304, 316, and 310 stainles s steels have been tested in $731 \mathrm{C}$ supercritical water at 5000 psi. No significant weight change was noted after 2 weeks of exposure of elements edge sheared to expose the core in two directions. Other tests were made on similar samples for 4 months in 260,310 , and $360 \mathrm{C}$ static demineralized wate $r$ with additional oxygen and hydrogen saturation. All samples revealed weight changes of only up to $0.116 \mathrm{mg} /\left(\mathrm{cm}^{2}\right)$ (month).

G1. Dimensional stability during irradiation ${ }^{(6)}$

Fuel plates containing various loadings of $\mathrm{UO}_{2}$ dispersed in different types of stainless steel matrices have been examined for dimensional stability after irradiation. Table Gl summarizes these data.

2. Fission-gas-release data $(7)$

The postirradiation examination of fuel plates which had a Type 347 stainless steel cladding with a core containing $26 \mathrm{w} / \mathrm{o} \mathrm{UO}_{2}$ dispersed in a matrix of prealloyed Type 347 stainless steel showed that some specimens had been ruptured. Using both mass and gamma-ray spectrographic techniques, a measured quantity of $4.8 \times 10^{-10} \mathrm{~cm}^{3}$ of fission gas at STP was determined for the unruptured specimens. For those specimens which had been ruptured, values of $2.3 \times 10^{-3} \mathrm{~cm}^{3}$ and $1.0 \times 10^{-2} \mathrm{~cm}^{3}$ of krypton-85 were determined.

3. Swelling-temperature data $(8)$

Data available were used in the preparation of Figure G6.

4. Unusual nuclear properties

No data available

\section{Property changes as a result of irradiation $(1)$}

Postirradiation-annealing studies were carried out on stainless steel- $\mathrm{UO}_{2}$ fuel materials. In Figure G5, the hardness of these materials is shown after irradiation and postirradiation annealing. 
TABLE G1. DIMENSIONAL CHANGE OF FLAT -PLATE

\begin{tabular}{|c|c|c|c|c|c|c|c|c|c|}
\hline \multicolumn{2}{|c|}{ Fuel } & \multicolumn{2}{|c|}{ Matrix } & \multirow{2}{*}{\multicolumn{3}{|c|}{ Core-to-Cladding Ratio }} & \multirow{2}{*}{\multicolumn{2}{|c|}{$\begin{array}{c}\text { Irradiation } \\
\text { Temperature, } \mathrm{F}\end{array}$}} & \multirow{3}{*}{$\begin{array}{c}\text { Uranium } \\
\text { Burnup, } \\
\text { a/o }\end{array}$} \\
\hline & Amount, & Stainless & Amount, & & & & & & \\
\hline Type(a) & & Type & & Length & Width & Thickness & Peak & Average & \\
\hline $\mathrm{S} \mathrm{UO}_{2}$ & 26 & 347 & 74 & 2 & 7 & 3 & $750^{(b)}$ & & \\
\hline $\mathrm{HUO}_{2}$ & 26 & 347 & 74 & 2 & 7 & 3 & 750 (b) & & 45 \\
\hline $\mathrm{HUO}_{2}$ & 26 & 347 & 74 & 2 & 7 & 3 & 750 (b) & & 45 \\
\hline $\mathrm{HUO}$ & 26 & 347 & 74 & 2 & 7 & 3 & 750 (b) & & 45 \\
\hline $\mathrm{HUO}$ & 26 & 347 & 74 & 2 & 7 & 3 & $750^{(b)}$ & & 45 \\
\hline $\mathrm{s} \mathrm{UO}_{2}^{2}$ & 26 & 347 & 74 & 2 & 7 & 3 & $750^{\text {(b) }}$ & & 45 \\
\hline $\mathrm{SUO}_{2}$ & 25.9 & 347 & 74.1 & 2 & 7 & 3 & $750^{(b)}$ & & 40 \\
\hline $\mathrm{HUO}_{2}$ & 26.1 & 347 & 73.9 & 2 & 7 & 3 & 750 (b) & & 40 \\
\hline $\mathrm{H} U \mathrm{O}_{2}$ & 26 & 347 & 74 & 2 & 7 & 3 & 750 (b) & & 40 \\
\hline $\mathrm{HUO}_{2}$ & 26 & 347 & 74 & 2 & 7 & 3 & 750 (b) & & 40 \\
\hline $\mathrm{SUO}_{2}$ & 26 & 347 & 74 & 2 & 7 & 3 & 750 (b) & & 40 \\
\hline $\mathrm{H} \mathrm{UO}_{2}$ & 26 & 347 & 74 & 2 & 7 & 3 & 750 (b) & & 40 \\
\hline $\mathrm{H} \mathrm{UO}_{2}$ & 24.2 & 347 & 75.8 & 2 & 7 & 3 & $750^{(b)}$ & & 40 \\
\hline $\mathrm{SUO}_{2}^{2}$ & 26 & 347 & 74 & 2 & 7 & 3 & $750^{(b)}$ & & 40 \\
\hline $\mathrm{S} \mathrm{UO}_{2}$ & 26 & 347 & 74 & 2 & 7 & 3 & 750 (b) & & 40 \\
\hline $\mathrm{S} \mathrm{UO}_{2}^{2}$ & 26 & 347 & 74 & 2 & 7 & 3 & 750 (b) & & 40 \\
\hline $\mathrm{S} \mathrm{UO}_{2}$ & 25.9 & 347 & 74.1 & 2 & 7 & 3 & 750 (b) & & 40 \\
\hline $\mathrm{HUO}_{2}$ & 24.2 & 347 & 75.8 & 2 & 7 & 3 & $750^{\text {(b) }}$ & & 40 \\
\hline $\mathrm{SUO}_{2}^{2}$ & 26 & 347 & 74 & 2 & 7 & 3 & $750^{\text {(b) }}$ & & 40 \\
\hline $\mathrm{S} \mathrm{UO}_{2}$ & 26 & 347 & 74 & 2 & 7 & 3 & $750^{(b)}$ & & 40 \\
\hline $\mathrm{S} \mathrm{UO}_{2}$ & 26 & 347 & 74 & 2 & 7 & 3 & 600 (b) & & 40 \\
\hline $\mathrm{HUO}_{2}$ & 26 & 347 & 74 & 2 & 7 & 3 & 600 (b) & & 40 \\
\hline $\mathrm{S} \mathrm{UO}_{2}^{2}$ & 26 & 347 & 74 & 2 & 7 & 3 & 600 (b) & & 40 \\
\hline $\mathrm{S} \mathrm{UO}_{0}$ & 26 & 347 & 74 & 2 & 7 & 3 & $600(b)$ & & 40 \\
\hline $\mathrm{S} \mathrm{UO}_{2}^{2}$ & 26 & 347 & 74 & 2 & 7 & 3 & 600 (b) & & 40 \\
\hline $\mathrm{HUO}_{2}$ & 26 & 347 & 74 & 2 & 7 & 3 & 600 (b) & & 40 \\
\hline $\mathrm{H} \mathrm{UO}_{2}$ & 25 & $318^{(c)}$ & 75 & 2 & 2.7 & 2.2 & -. & -- & 5.4 \\
\hline $\mathrm{H} \mathrm{UO}_{2}$ & 30 & 318 & 70 & 2 & 2.7 & 2.2 & - & -- & 6.1 \\
\hline $\mathrm{H} \mathrm{UO}_{2}$ & 25 & 318 & 75 & 2 & 2.7 & 2.2 & -- & $1500^{(d)}$ & 5.4 \\
\hline $\mathrm{H} \mathrm{UO}_{2}$ & 30 & 318 & 70 & 2 & 2.7 & 2.2 & - & $1529^{(d)}$ & 7.2 \\
\hline $\mathrm{H} \mathrm{UO}_{2}$ & 25 & 318 & 75 & 2 & 2.7 & 2.2 & -- & $1248^{(d)}$ & 13.4 \\
\hline $\mathrm{H} \mathrm{UO}_{2}$ & 30 & 318 & 70 & 2 & 2.7 & 2.2 & -- & 1390 (d) & 17.5 \\
\hline $\mathrm{H} \mathrm{UO}_{2}^{4}$ & 25 & 318 & 75 & 2 & 2.7 & 2.2 & -- & $1477^{(d)}$ & 16.2 \\
\hline $\mathrm{H} \mathrm{UO}_{2}$ & 30 & 318 & 70 & 2 & 2.7 & 2.2 & -- & 1325 (d) & 15.6 \\
\hline $\mathrm{HUO}_{2}$ & 25 & 318 & 75 & 2 & 2.7 & 2.2 & -- & $1280^{(d)}$ & 24.5 \\
\hline $\mathrm{H} \mathrm{UO}_{2}^{2}$ & 25 & 318 & 75 & 2 & 2.7 & 2.2 & -- & $1238^{(d)}$ & 24.7 \\
\hline $\mathrm{HUO}_{2}$ & 25 & 318 & 75 & 2 & 2.7 & 2.2 & -- & 1055 (d) & 22.2 \\
\hline $\mathrm{H} \mathrm{UO}_{2}$ & 30 & 318 & 70 & 2 & 2.7 & 2.2 & -. & $\sim 1600$ (d) & 3.1 \\
\hline $\mathrm{HUO}_{2}$ & 25 & 318 & 75 & 2 & 2.7 & 2.2 & 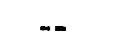 & $\sim 1600^{(d)}$ & 3.2 \\
\hline $\mathrm{HUO}_{2}^{2}$ & 25 & 318 & 75 & 2 & 2.7 & 2.2 & -- & $\sim 1600$ (d) & 3.8 \\
\hline $\mathrm{H} \mathrm{UO}_{2}^{2}$ & 30 & 318 & 70 & 2 & 2.7 & 2.2 & -- & $\sim 1600$ (d) & 3.6 \\
\hline $\mathrm{S} \mathrm{UO}_{2}$ & 30 & 318 & 70 & 2 & 2.7 & 2.8 & 1375 & 1239 (d) & 15.1 \\
\hline $\mathrm{HUO}_{2}$ & 30 & 318 & 70 & 2 & 2.7 & 2.8 & 1335 & $1186^{(d)}$ & 15.4 \\
\hline $\mathrm{S} \mathrm{UO}_{2}$ & 30 & 318 & 70 & 2 & 2.7 & 2.8 & 1325 & $1128^{(d)}$ & 14.2 \\
\hline $\mathrm{H} \mathrm{UO}_{2}$ & 30 & 318 & 70 & 2 & 2.7 & 2.8 & 1120 & $967^{(d)}$ & 17.1 \\
\hline
\end{tabular}




\begin{tabular}{|c|c|c|c|c|c|c|c|c|}
\hline \multirow{2}{*}{\multicolumn{3}{|c|}{$\begin{array}{c}\text { Over-All Specimen } \\
\text { Dimensions, in. }\end{array}$}} & \multicolumn{4}{|c|}{ Dimensional Change, per cent } & \multirow{3}{*}{$\begin{array}{c}\text { Density } \\
\text { Loss, } \\
\text { per cent }\end{array}$} & \multirow[b]{3}{*}{ Specimen Condition } \\
\hline & & & & & Thick & zess & & \\
\hline Length & Width & Thickness & Length & Width & Maxımum & Average & & \\
\hline 1.506 & 0.570 & 0.040 & -- & -- & - & -. & -- & Blistered \\
\hline 1.506 & 0.570 & 0.040 & 0.07 & 0.09 & -- & 5.3 & 1.9 & Good condition, no blistering or warpage \\
\hline 1.506 & 0.570 & 0.040 & 0.15 & 0.07 & -- & 6.0 & 22 & Ditto \\
\hline 1506 & 0.570 & 0.040 & 0.79 & 019 & -- & 2.6 & 2.7 & Ditto \\
\hline 1.506 & 0570 & 0.040 & 0.11 & 0.09 & -- & 4.8 & 2.5 & Ditto \\
\hline 1506 & 0570 & 0040 & 004 & 009 & -- & 4.5 & 2.5 & Ditto \\
\hline 1.506 & 0.570 & 0.040 & 0.17 & 034 & -- & 5.0 & 1.4 & Ditto \\
\hline 1.506 & 0.570 & 0.040 & -- & 0.12 & -- & 6.3 & 2.7 & Ditto \\
\hline 1.506 & 0.570 & 0.040 & 0.17 & 0.38 & -- & 5.5 & 2.9 & Ditto \\
\hline 1.506 & 0.570 & 0.040 & -- & 0.35 & - & 5.4 & 2.6 & Ditto \\
\hline 1.506 & 0.570 & 0.040 & 0.15 & 0.17 & -- & 5.8 & 3.1 & Ditto \\
\hline 1.506 & 0.570 & 0.040 & -- & 0.14 & -- & 6.6 & 2.9 & Ditto \\
\hline 1.506 & 0.570 & 0.040 & 0.19 & -- & -- & 4.8 & 2.4 & Ditto \\
\hline 1.506 & 0.570 & 0.040 & 0.09 & 0.04 & -- & 4.2 & 2.2 & Ditto \\
\hline 1.506 & 0.570 & 0.040 & 0.26 & 0.21 & -- & 4.2 & 2.0 & Ditto \\
\hline 1.506 & 0.570 & 0.040 & -- & 0.14 & -- & 4.5 & 1.8 & Ditto \\
\hline 1.506 & 0.570 & 0.040 & 0.36 & 0.19 & -- & 3.6 & 1.7 & Ditto \\
\hline 1.506 & 0.570 & 0.040 & 0.75 & 0.86 & -- & 3.9 & 1.9 & Ditto \\
\hline 1.506 & 0.570 & 0.040 & 0.24 & 0.09 & -- & 3.6 & 1.8 & Ditto \\
\hline 1.506 & 0.570 & 0.040 & -- & - & -- & -- & -- & Blistered, fused \\
\hline 1.506 & 0.570 & 0.040 & -- & 0.12 & -- & 6.4 & 2.2 & Good condition, no blistering or warpage \\
\hline 1.506 & 0.570 & 0.040 & 0.09 & 0.09 & -- & 2.9 & 2.1 & Ditto \\
\hline 1.506 & 0.570 & 0.040 & 0.05 & 0.09 & -- & 3.6 & 1.6 & Ditto \\
\hline 1.506 & 0.570 & 0.040 & 0.05 & 0.09 & -- & 5.5 & 1.8 & Ditto \\
\hline 1.506 & 0.570 & 0.040 & 0.12 & 0.23 & $\cdots$ & 1.7 & 1.4 & Ditto \\
\hline 1.506 & 0.570 & 0.040 & 0.86 & 0.31 & -- & 2.7 & 0.9 & Ditto \\
\hline 1.5 & 0.687 & 0.045 & -1.56 & 0.07 & 12.42 & 0.57 & 0.00 & Good surface but warped \\
\hline 1.5 & 0.687 & 0.045 & -0.96 & 0.20 & 73.58 & 13.32 & 2.23 & Large blister \\
\hline 1.5 & 0687 & 0.045 & -- & 019 & 10.92 & 3.71 & 1.04 & Good \\
\hline 1.5 & 0.687 & 0.045 & -0.14 & 0.13 & 18.16 & 2.63 & 1.15 & Small blister \\
\hline 1.5 & 0.687 & 0.045 & -- & 0.00 & 2.17 & 1.52 & 0.86 & Good \\
\hline 1.5 & 0.687 & 0.045 & -0.20 & 0.08 & 10.94 & 5.79 & -2.09 & Small blister \\
\hline 1.5 & 0.687 & 0.045 & -0.10 & 0.00 & 5.49 & 4.18 & 1.72 & Good \\
\hline 1.5 & 0.687 & 0.045 & -- & 0.00 & 25.27 & 6.26 & 1.84 & Ruptured \\
\hline 1.5 & 0.687 & 0.045 & -0.12 & 0.19 & 23.04 & 7.61 & 3.70 & Large blister \\
\hline 1.5 & 0.687 & 0.045 & -- & -- & -- & -- & -- & Small blister \\
\hline 1.5 & 0.687 & 0.045 & -- & -- & -- & $\cdots$ & -- & Blistered, ruptured \\
\hline 1.5 & 0.687 & 0.045 & 0.00 & 0.00 & 0.00 & 0.00 & 0.00 & Good, no blistering or warpage \\
\hline 1.5 & 0.687 & 0.045 & -0.11 & 0.00 & 0.00 & 0.00 & 0.00 & Ditto \\
\hline 1.5 & 0.687 & 0.045 & 0.00 & 0.00 & 0.00 & 0.00 & 0.00 & Ditto \\
\hline 1.5 & 0.687 & 0.045 & -0.12 & 0.06 & 0.06 & 0.68 & 0.00 & Ditto \\
\hline 1.5 & 0.687 & 0.045 & 0.00 & 0.00 & -- & 2.6 & 0.8 & Good, no blustering or warpage \\
\hline 1.5 & 0.687 & 0.045 & 0.00 & 0.00 & - & 2.0 & 0.7 & Ditto \\
\hline 1.5 & 0.687 & 0.045 & 0.00 & 0.00 & - & 2.2 & 0.7 & Ditto \\
\hline 1.5 & 0.687 & 0.045 & 0.00 & 0.00 & -- & 2.0 & 0.5 & Ditto \\
\hline
\end{tabular}


TABLE G1.

\begin{tabular}{|c|c|c|c|c|c|c|c|c|c|}
\hline \multicolumn{2}{|c|}{ Fuel } & \multicolumn{2}{|c|}{ Matrix } & \multirow{2}{*}{\multicolumn{3}{|c|}{ Core-to-Cladding Ratio }} & \multirow{2}{*}{\multicolumn{2}{|c|}{$\begin{array}{c}\text { Irradiation } \\
\text { Temperature, F }\end{array}$}} & \multirow{3}{*}{$\begin{array}{c}\text { Uranium } \\
\text { Burnup, } \\
\text { a/o }\end{array}$} \\
\hline \multirow[b]{2}{*}{ Type ${ }^{(a)}$} & \multirow{2}{*}{$\begin{array}{c}\text { Amount, } \\
\mathrm{w} / \mathrm{O}\end{array}$} & \multirow[b]{2}{*}{ Type } & \multirow{2}{*}{$\begin{array}{c}\text { Amount, } \\
\mathrm{w} / \mathrm{o}\end{array}$} & & & & & & \\
\hline & & & & Length & Width & Thickness & Peak & Average & \\
\hline $\mathrm{HUO}_{2}$ & 30 & 318 & 70 & 2 & 2.7 & 2.8 & 1565 & 1355 (d) & 11.8 \\
\hline $\mathrm{S} \mathrm{UO}_{2}^{2}$ & 30 & 318 & 70 & 2 & 2.7 & 2.8 & 1620 & $1402^{(d)}$ & 11.8 \\
\hline $\mathrm{HUO}_{2}^{2}$ & 30 & 318 & 70 & 2 & 2.7 & 2.8 & -- & -- & 11.5 \\
\hline $\mathbf{S} \mathbf{U O}_{2}{ }^{2}$ & 30 & 318 & 70 & 2 & 2.7 & 2.8 & 1300 & $1155^{(d)}$ & 10.4 \\
\hline UN & 24 & 318 & 76 & 2 & 2.7 & 2.8 & -- & 1600 (d) & 5.4 \\
\hline UC & 24 & 318 & 76 & 2 & 2.7 & 2.8 & - & $1710^{(d)}$ & 6.6 \\
\hline UN & 24 & 318 & 76 & 2 & 2.7 & 2.8 & -- & 1800 (d) & 7.7 \\
\hline UC & 24 & 318 & 76 & 2 & 2.7 & 2.8 & -- & $1800^{(d)}$ & 7.8 \\
\hline UN & 24 & 318 & 76 & 2 & 2.7 & 2.8 & -- & $1490^{(d)}$ & 2.2 \\
\hline UC & 24 & 318 & 76 & 2 & 2.7 & 2.8 & - & 1600 (d) & 2.1 \\
\hline UN & 24 & 318 & 76 & 2 & 2.7 & 2.8 & -- & 1720 (d) & -- \\
\hline UC & 24 & 318 & 76 & 2 & 2.7 & 2.8 & -- & $1490^{(d)}$ & 3.4 \\
\hline UN & 24 & 318 & 76 & 2 & 2.7 & 2.8 & - & $1390^{(d)}$ & -- \\
\hline UN & 24 & 318 & 76 & 2 & 2.7 & 2.8 & -- & 1625 (d) & 12 \\
\hline UC & 24 & 318 & 76 & 2 & 2.7 & 2.8 & -- & 1600 (d) & 12 \\
\hline \multirow[t]{2}{*}{ UC } & 24 & 318 & 76 & 2 & 2.7 & 2.8 & -- & 1460 (d) & -- \\
\hline & & & & & & & Max. & Min. & \\
\hline $\mathrm{HUO}_{2}$ & 30 & 318 & 70 & 2 & 2.7 & 2.8 & 1880 & 1500 (d) & 3.6 \\
\hline $\mathrm{UN}^{2}$ & 28 & 318 & 72 & 2 & 2.7 & 2.8 & $>1800(\mathrm{e})$ & 1575 (d) & 4.8 \\
\hline UN & 28 & 318 & 72 & 2 & 2.7 & 2.8 & $>1850(\mathrm{e})$ & 1590 (d) & 5.0 \\
\hline UN & 28 & 318 & 72 & 2 & 2.7 & 2.8 & $>1750(\mathrm{e})$ & 1470 (d) & 4.3 \\
\hline
\end{tabular}

(a) $\mathrm{H}=$ hydrothermal, $\mathrm{S}=$ spherical $\mathrm{UO}_{2}$.

(b) Specimen surface temperature.

(c) Elemental blend of iron, chromium, nickel, and molybdenum powders in all Type 318 stainless steel matrices.

(d) Central core temperature.

(e) Thermocouples were inoperative last two cycles of the reactor. Specimens may have reached 1900 to $2000 \mathrm{~F}$. 
(Contunued)

\begin{tabular}{|c|c|c|c|c|c|c|c|c|}
\hline \multirow{2}{*}{\multicolumn{3}{|c|}{$\begin{array}{c}\text { Over-All specimen } \\
\text { Dimensions, } 1 \mathrm{n} .\end{array}$}} & \multicolumn{4}{|c|}{ Dimensional Change, per cent } & \multirow{3}{*}{$\begin{array}{l}\text { Density } \\
\text { Loss, } \\
\text { per cent }\end{array}$} & \multirow[b]{3}{*}{ Specimen Condition } \\
\hline & & & \multirow[b]{2}{*}{ Length } & \multirow[b]{2}{*}{ Width } & \multicolumn{2}{|c|}{ Thickness } & & \\
\hline Length & Width & Thickness & & & Maximum & A verage & & \\
\hline 1.5 & 0.687 & 0.045 & 0.00 & 0.00 & -. & 2.4 & 0.4 & Good, no blistering or warpage \\
\hline 1.5 & 0.687 & 0.045 & 0.00 & 0.00 & -- & 2.4 & 0.6 & Ditto \\
\hline 1.5 & 0.687 & 0.045 & 0.00 & 0.00 & -- & 2.2 & 0.7 & Ditto \\
\hline 1.5 & 0.687 & 0.045 & 0.00 & 0.00 & -- & 2.0 & 0.4 & Ditto \\
\hline 1.5 & 0.687 & 0.045 & -- & -- & -- & 1.3 & 0.37 & Ditto \\
\hline 1.5 & 0.687 & 0.045 & -- & -- & -- & 1.7 & 2.88 & Blister \\
\hline 1.5 & 0.687 & 0.045 & -- & - & -- & 2.3 & 2.16 & Blister \\
\hline 1.5 & 0.687 & 0.045 & -- & -- & -- & 1.5 & 6.12 & Blister \\
\hline 1.5 & 0.687 & 0.045 & - & -- & - & 0.9 & 0.28 & -- \\
\hline 1.5 & 0.687 & 0.045 & -- & -- & -- & 0.4 & 0.08 & -- \\
\hline 1.5 & 0.687 & 0.045 & -- & -- & -- & 0.2 & $\mathrm{~N} 11$ & -- \\
\hline 1.5 & 0.687 & 0.045 & -- & -- & -- & 0.2 & 0.28 & -- \\
\hline 1.5 & 0.687 & 0.045 & -- & -- & -- & 1.3 & 1.71 & -- \\
\hline 1.5 & 0.687 & 0.045 & -- & -- & -- & 3.1 & 0.8 & Good, no blistering or cracking \\
\hline 1.5 & 0.687 & 0.045 & -- & -- & -- & 3.2 & 2.15 & Blister \\
\hline \multirow[t]{2}{*}{1.5} & 0.687 & 0.045 & -- & -- & -- & 3.2 & 2.04 & Slister \\
\hline & & & & & Blister & & & \\
\hline 1.5 & 0.687 & 0.045 & -- & - & 30 & 0.00 & 1.2 & Small blister, no warpage \\
\hline 1.5 & 0.687 & 0.045 & -- & -- & 29 & 0.00 & 1.3 & Small blıster, no warpage \\
\hline 1.5 & 0.687 & 0.045 & -- & -- & 25 & 0.00 & 1.5 & Small blıster, no warpage \\
\hline 1.5 & 0.687 & 0.045 & -- & -- & 23 & 0.00 & 0.6 & Small blister, no warpage \\
\hline
\end{tabular}




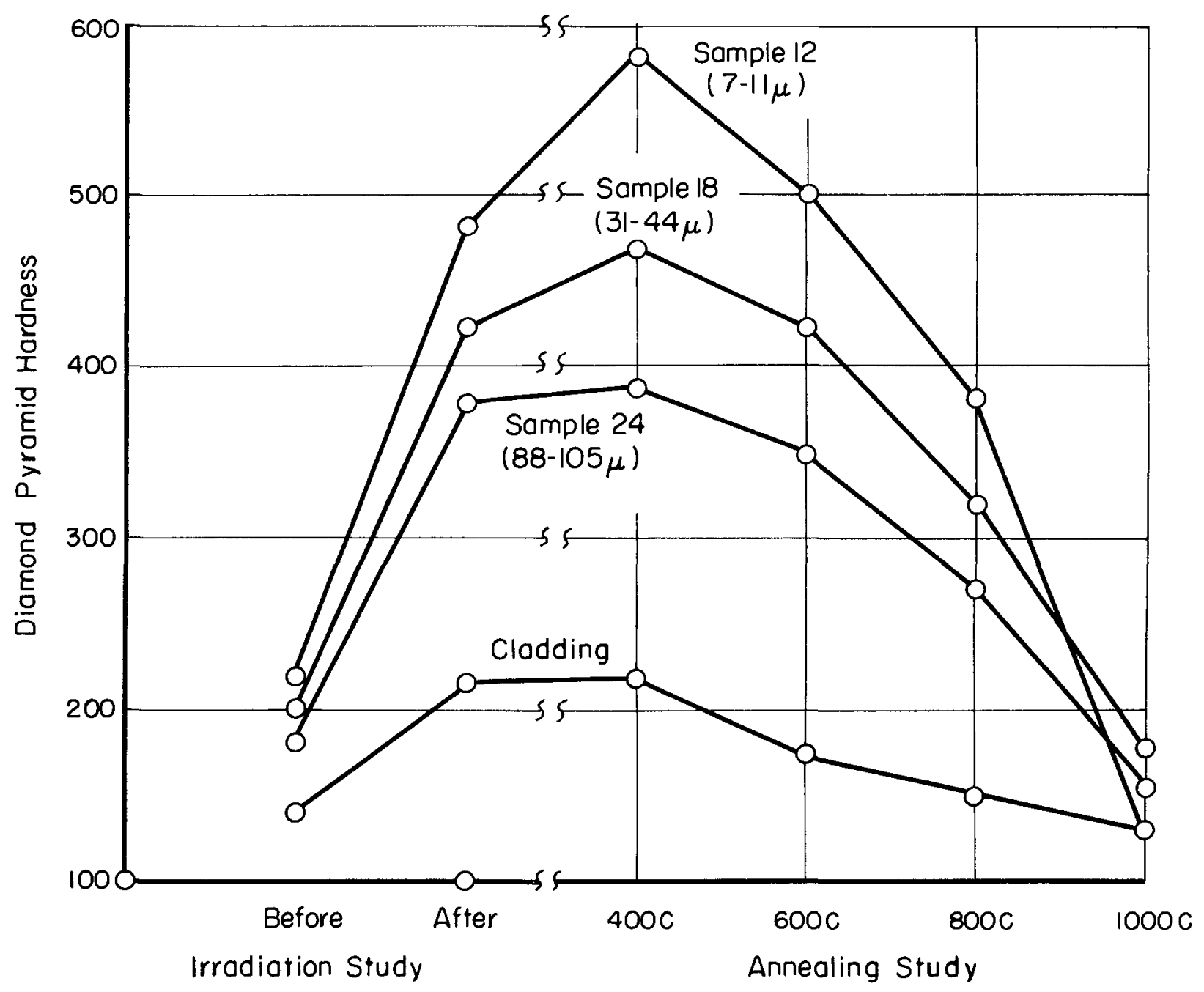

FIGURE G5. SUMMARY OF POSTIRRADIATION ANNEALING STUDIES ON STAINLESS STEEL - UO ${ }_{2}$ FUEL MATERIALS ${ }^{(1)}$ 
6. Failure versus temperature data $(8-11)$

Figure G6 and Table G6 summarize the results of many capsule irradiations of $\mathrm{UO}_{2}$-stainless ste $\epsilon 1$ fuel-element specimens.

\section{H. References}

(1) Keller, D. L. , "Dispersion Fuels", Reactor Handbook, Volume 1 Materials, Interscience Publishers, Inc., New York (1960), pp 304-330.

(2) Cunningham, J. E., Beaver, R. J., Thurber, W. C., and Waugh, R. C., "Fuel Dispersions in Aluminum-Base Elements for Research Reactors", Fuel Elements Conference, Paris, November 18-23, 1957, TID-7546 (March, 1958), pp 269-297.

(3) Paprocki, S. J., Keller, D. L., and Fackelmann, J. M., "Properties of Uranium Dioxide-Stainless Steel Dispersion Fuel Plates", BMI-1339 (April, 1959).

(4) Meny, L., Buffet, J., and Sauve, C., "Powder Sintering and Extrusion for the Fabrication of $\mathrm{U}-\mathrm{Al}$ and $\mathrm{UO}_{2}$-Stainless Steel Dispersion", 4th Plansee Seminar, Austria, June 20-24, 1961.

(5) Keeler, J. R., and Cuddy, L. J., "Properties of Stainless Steel-Uranium Dioxide Fuel Plates", BMI-913 (May, 1954).

(6) Lozier, D. E., BMI, Unpublished Data.

(7) Paprocki, S. J., Dickerson, R. F., Cunningham, G. W., Murr, W. E., and Lozier, D. E., "Fabrication and Irradiation of SM-2 Core Materials", BMI-1528 (July 12, 1961).

(8) Keller, D. L., "Predicting Burnup of Stainless-UO 2 Cermet Fuels", Nucleonics, 19 (6), 45-48 (June, 1961).

(9) Haynes, V. O., Neill, F. H., and Schafler, L. D., "Summary of UO $\mathrm{U}_{2}$-Stainless Steel Dispersion Irradiation Experiments", ORNL-CF-58-2-71 (March 18, 1958).

(10) Keller, D. L., Hulbert, L. E., and Dunnington, B. W. , "A Method of Correlating Irradiation Effects in Dispersion Fuels", BMI-1408 (January 20, 1960).

(11) Saling, J. H., BMI, Unpublished Data. 


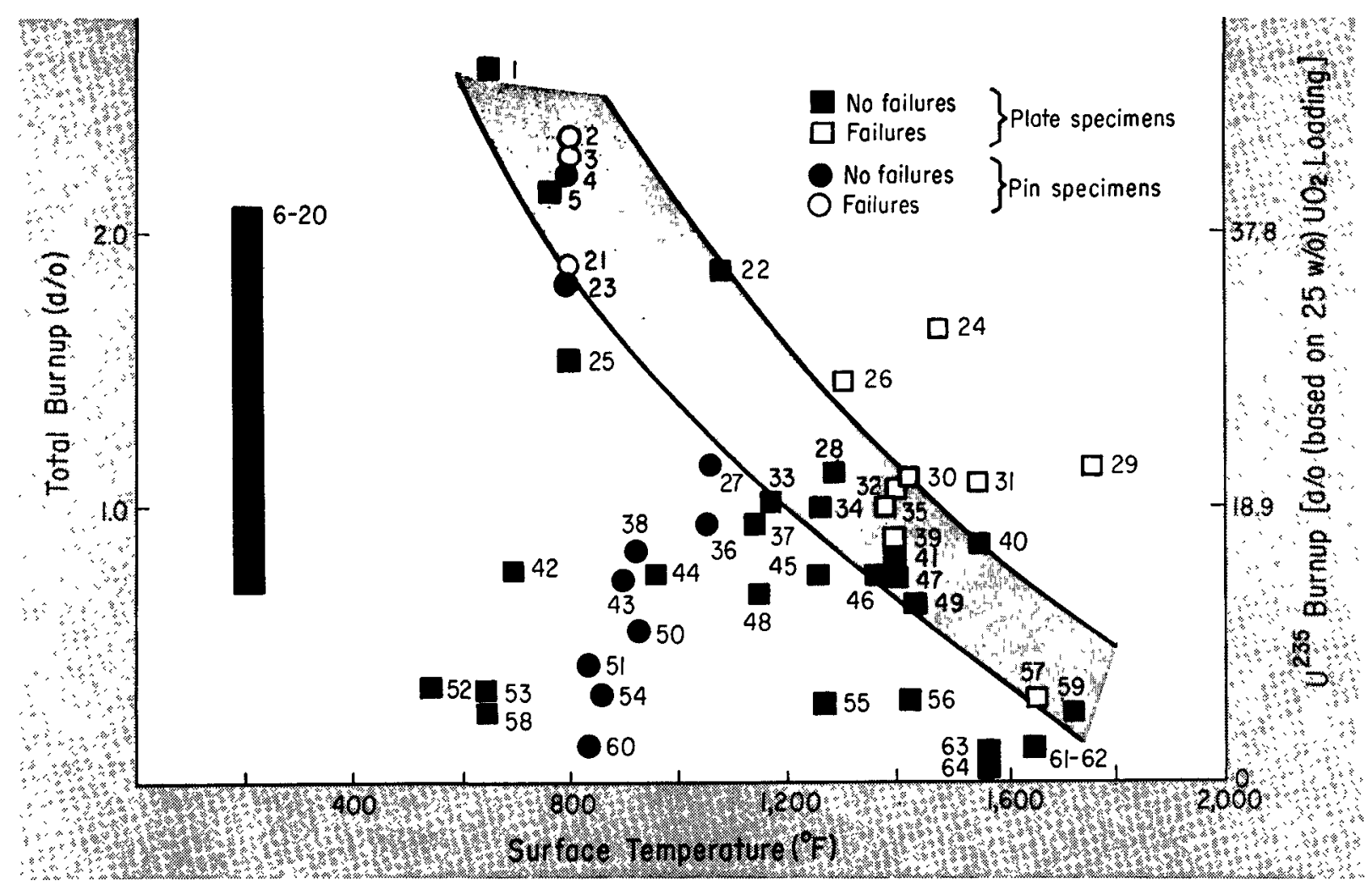

FIGURE G6. BURNUP PERFORMANCE OF STAINLESS-STEEL- $U \mathrm{O}_{2}$ CERMET FUEL SPECIMENS HAVING 18-30 W/O $\mathrm{UO}_{2}$

(Numbers next to dato points are specimen numbers shown in Table G6).

These data indicate that when a specimen temperature and burnup are below shaded area, a "typical "fuel element will not crack or blister (as seen visually or microscopically) or release radioactive products. Fuels exposed above shaded zone would fail; performance of fuels. irradiated within shaded area is difficult to predict. ${ }^{(8)}$ 


\begin{tabular}{|c|c|c|c|c|c|c|c|c|c|c|c|}
\hline \multirow[b]{2}{*}{ Matrix } & \multirow[b]{2}{*}{ Claddıng } & \multirow[b]{2}{*}{$\begin{array}{c}\mathrm{UO}_{2} \\
\text { Loading, } \\
\text { w/o }\end{array}$} & \multicolumn{2}{|c|}{$\begin{array}{c}\text { Specimen } \\
\text { Characteristics }\end{array}$} & \multicolumn{4}{|c|}{ Irradiation Conditions } & \multirow[b]{2}{*}{ Results } & \multirow[b]{2}{*}{$\begin{array}{l}\text { Identification } \\
\text { in Figure G6 }\end{array}$} & \multirow[b]{2}{*}{ Reference } \\
\hline & & & $\begin{array}{c}\mathrm{UO}_{2} \\
\text { Particle } \\
\text { Size, } \mu \\
\end{array}$ & $\begin{array}{c}\text { Cladding } \\
\text { Thickness, } \\
\text { mils }\end{array}$ & $\begin{array}{c}\text { Surface } \\
\text { Temperature, } \\
\text { F }\end{array}$ & $\begin{array}{c}\text { Irradiation } \\
\text { Time, } \\
\text { hr }\end{array}$ & $\frac{\text { Burm }}{\mathrm{U}^{235}}$ & $\begin{array}{c}p, a / 0 \\
\text { Total }\end{array}$ & & & \\
\hline \multicolumn{12}{|c|}{ Plates } \\
\hline \multirow{15}{*}{ Type 304} & Type $304 \mathrm{~L}$ & 1792 & -- & 5 & 190 & - & 52.5 & 1.93 & No fallures & $6-20$ & (9) \\
\hline & & 1792 & -. & 5 & 190 & -- & 40.0 & 1.48 & Ditto & $6-20$ & (9) \\
\hline & & 17.92 & -- & 5 & 190 & -- & 45.4 & 1.68 & Ditto & $6-20$ & (9) \\
\hline & & 17.92 & -- & 5 & 190 & -- & 10.5 & 0.39 & Ditto & $6-20$ & (9) \\
\hline & & 1792 & -- & 5 & 190 & -- & 40.0 & 1.48 & Ditto & $6-20$ & (9) \\
\hline & & 17.92 & -- & 5 & 190 & -- & 53.5 & 1.98 & Ditto & $6-20$ & (9) \\
\hline & & 17.92 & -- & 5 & 190 & -- & 51.2 & 1.89 & Ditto & $6-20$ & (9) \\
\hline & & 17.92 & -- & 5 & 190 & -- & 13.1 & 0.48 & Ditto & $6-20$ & (9) \\
\hline & & 17.92 & -- & 5 & 190 & -- & 56.9 & 2.10 & Ditto & $6-20$ & (9) \\
\hline & & 17.92 & $\ldots$ & 5 & 190 & -- & 53.1 & 1.96 & Ditto & $6-20$ & (9) \\
\hline & & 17.92 & -- & 5 & 190 & $\ldots$ & 48.1 & 1.78 & Ditto & $6-20$ & (9) \\
\hline & & 17.92 & -- & 5 & 190 & -- & 29.2 & 1.08 & Ditto & $6-20$ & (9) \\
\hline & & 18.75 & - & 8 & 212 & 400 & 16.0 & 0.7 & Ditto & $6-20$ & (9) \\
\hline & & 22.18 & -- & 10 & 212 & 400 & 18.0 & 0.9 & Ditto & $6-20$ & (9) \\
\hline & & 26.89 & -- & 12 & 212 & 400 & 12.0 & 0.8 & Ditto & $6-20$ & (9) \\
\hline \multirow{12}{*}{$\begin{array}{l}\mathrm{Fe}-18 \mathrm{Cr}-14 \mathrm{~N}_{1}- \\
2.5 \mathrm{Mo} \\
\text { (elementa } 1)\end{array}$} & Type 318 & 25 & $75-150$ & 6 & 1725 & 32.7 & 5.4 & 0.29 & No failures & 59 & (10) \\
\hline & & 25 & $75-150$ & 6 & 1430 & 47.5 & 12.7 & 0.67 & Ditto & 49 & (10) \\
\hline & & 25 & $75-150$ & 6 & 1550 & 47.5 & 16.6 & 0.88 & Ditto & 40 & (10) \\
\hline & & 25 & $75-150$ & 6 & 1400 & 85.2 & 20.4 & 1.08 & Large bluster & 32 & (10) \\
\hline & & 25 & $75-150$ & 6 & 1417 & 85.2 & 20.7 & 1.10 & Small blister & 30 & (10) \\
\hline & & 25 & $75-150$ & 6 & 1650 & 52.7 & 2.2 & 0.12 & No fallures & 61 & (10) \\
\hline & & 25 & $75-150$ & 6 & 1650 & 52.7 & 2.6 & 0.14 & Ditto & 62 & (10) \\
\hline & & 30 & $75-150$ & 6 & 1655 & 32.7 & 4.9 & 0.32 & Small bluster & 57 & (10) \\
\hline & & 30 & $75-150$ & 6 & 1533 & 47.5 & 17.5 & 1.15 & Ditto & 31 & $(10)$ \\
\hline & & 30 & $75-150$ & 6 & 1395 & 47.5 & 15.6 & 1.04 & Ruptured & 35 & (10) \\
\hline & & 30 & $75-150$ & 6 & 1475 & 85.2 & 25.1 & 1.66 & Ditto & 24 & (10) \\
\hline & & 30 & $75-150$ & 6 & 1300 & 85.2 & 22.2 & 1.47 & Ditto & 26 & (10) \\
\hline \multirow{10}{*}{$\begin{array}{r}F e-18 \mathrm{Cr}-9 \mathrm{~N} 1 \\
\quad(\text { elemental })\end{array}$} & Type 347 & 30 & $>44$ & 6 & 550 & 610 & 5.3 & 0.35 & 8 preces, 0 falled & 52 & (9) \\
\hline & & 30 & $>44$ & 4 & 650 & 425 & 4.4 & 0.29 & Ditto & 58 & (9) \\
\hline & & 30 & $>44$ & 4 & 650 & 412 & 5.4 & 0.36 & Ditto & 53 & (9) \\
\hline & & 30 & $>44$ & 4 & 700 & 1038 & 12.1 & 0.79 & Ditto & 42 & (9) \\
\hline & & 30 & $>44$ & 4 & 650 & 2550 & 39.7 & 2.6 & Ditto & I & (9) \\
\hline & & 30 & $>44$ & 4 & 800 & -- & 23.5 & 1.54 & Ditto & 25 & (9) \\
\hline & & 30 & $>44$ & 4 & 766 & 4015 & 33.3 & 2.17 & Ditto & 5 & (9) \\
\hline & & 30 & $>44$ & 4 & 1080 & 2415 & 28.6 & 1.86 & Ditto & 22 & (9) \\
\hline & & 30 & $>44$ & 4 & 1400 & 1889 & 12.9 & 0.84 & 8 pieces, 2 cracked & 39,41 & (9) \\
\hline & & 30 & $>44$ & 4 & 1765 & 880 & 17.4 & 1.14 & 8 preces, all farled & 29 & (9) \\
\hline \multirow[t]{4}{*}{ Type 310} & Type 310 & 30 & $>105$ & 5 & 1260 & 370 & 4.6 & 0.30 & 2 preces, 0 falled & 55 & (9) \\
\hline & & 30 & $>105$ & 5 & 1420 & 420 & 4.8 & 0.31 & Ditto & 56 & (9) \\
\hline & & 30 & $>105$ & 5 & 1560 & 370 & 1.8 & 0.12 & Ditto & 63 & (9) \\
\hline & & 30 & $>44$ & 4 & 1550 & 288 & 1.1 & 0.09 & Ditto & 64 & (9) \\
\hline
\end{tabular}


TABLE G6. (Continued)

\begin{tabular}{|c|c|c|c|c|c|c|c|c|c|c|c|}
\hline \multirow[b]{2}{*}{ Matrix } & \multirow[b]{2}{*}{ Claddıng } & \multirow[b]{2}{*}{$\begin{array}{c}\mathrm{UO}_{2} \\
\text { Loading, } \\
\text { w/o } \\
\end{array}$} & \multicolumn{2}{|c|}{$\begin{array}{c}\text { Specimen } \\
\text { Characteristics }\end{array}$} & \multicolumn{4}{|c|}{ Irradiation Conditior.s } & \multirow[b]{2}{*}{ Results } & \multirow[b]{2}{*}{$\begin{array}{l}\text { Identification } \\
\text { in Figure G6 }\end{array}$} & \multirow[b]{2}{*}{ Reference } \\
\hline & & & $\begin{array}{c}\mathrm{UO}_{2} \\
\text { Particle } \\
\text { Size, } \mu \\
\end{array}$ & $\begin{array}{c}\text { Cladding } \\
\text { Thickness, } \\
\text { mis }\end{array}$ & $\begin{array}{c}\text { Surface } \\
\text { Temperature, } \\
F \\
\end{array}$ & $\begin{array}{c}\text { Irradiation } \\
\text { Time, } \\
\text { hr }\end{array}$ & \multicolumn{2}{|c|}{$\frac{\text { Burnup, a } / 0}{\mathrm{U}^{235} \text { Total }}$} & & & \\
\hline \multicolumn{12}{|c|}{$\frac{\text { Plates }}{\text { (Contmued) }}$} \\
\hline $\begin{array}{c}\text { Fe }-23 \mathrm{Cr}-17 \mathrm{~N} 1 \\
\text { (elemental) }\end{array}$ & Type 318 & 30 & $>44$ & 4 & 1290 & 815 & 17 & 1.12 & No fallures & 28 & (9) \\
\hline$F e-18 C r-14 N_{1}-$ & Type 318 & 30 & $75-150$ & 6 & 1240 & 2250 & 15.1 & 1.00 & No fallures & 34 & (II) \\
\hline $2,5 \mathrm{MO}$ & & 30 & $75-150$ & 6 & 1190 & 2250 & 15.4 & 1.02 & Ditto & 33 & (11) \\
\hline \multirow{6}{*}{ (elemental } & & 30 & $75-150$ & 6 & 1130 & 2250 & 14.2 & 0.94 & Ditto & 37 & (11) \\
\hline & & 30 & $75-150$ & 6 & 970 & 2250 & 12.0 & 0.79 & Ditto & 44 & (11) \\
\hline & & 30 & $75-150$ & 6 & 1360 & 1474 & 11.8 & 0.78 & Ditto & 46 & (11) \\
\hline & & 30 & $75-150$ & 6 & 1400 & 1474 & 11.8 & 0.78 & Ditto & 47 & (11) \\
\hline & & 30 & $75-150$ & 6 & 1270 & 1474 & 11.5 & 0.76 & Ditto & 45 & (11) \\
\hline & & 30 & $75-150$ & 6 & 1140 & 1474 & 10.4 & 0.69 & Ditto & 48 & (11) \\
\hline \multicolumn{12}{|c|}{ Pins } \\
\hline \multirow[t]{5}{*}{ Type 347} & Type 347 & 23 & -- & 10 & 860 & 790 & 6.7 & 0.33 & No fallures & 54 & (9) \\
\hline & & 24 & -- & 10 & 930 & -- & 16 & 0.82 & Ditto & 38 & (9) \\
\hline & & 24 & -- & 10 & 842 & -- & 3 & 0.15 & Ditto & 60 & (9) \\
\hline & & 24 & -- & 10 & 842 & -- & 8.2 & 0.42 & Ditto & 51 & (9) \\
\hline & & 30 & -- & 10 & 930 & 1000 & 8.9 & 0.58 & Ditto & 50 & (9) \\
\hline \multirow{6}{*}{$\begin{array}{c}\mathrm{Fe}-18 \mathrm{Cr}-12 \mathrm{~N} 1 \\
\text { (elemental) }\end{array}$} & Type 304 & 24.5 & -- & 10 & 1060 & 2790 & 18 & 0.94 & No failures & 36 & (9) \\
\hline & & 28.5 & - & 10 & 1060 & 2790 & 18 & 1.13 & Ditto & 27 & (9) \\
\hline & & 28.5 & -- & 10 & 900 & - & 12 & 0.75 & Ditto & 43 & (9) \\
\hline & & 30 & $44-74$ & $10 f$ & 800 & 1662 & 28 & 1.85 & 2 pieces, 1 falled & 21,23 & (9) \\
\hline & & 30 & $44-74$ & 10 & 800 & 2520 & 34 & 2.24 & Ditto & 3,4 & (9) \\
\hline & & 30 & $44-74$ & 10 & 800 & 3310 & 35 & 2.31 & Ruptured & 2 & (9) \\
\hline
\end{tabular}

* This table includes data only from experiments in which temperatures were carefully monitored and burnup was measured either radiochemically or $150 t o p i c a l l y$ + The conversion to a/o burnup $1 \mathrm{~s}$ based on a U enrichment of $93 \%$ in all cases.

+ Type-347ss cladding. 


\section{CERMETS}




\title{
UC CERMETS
}

\author{
Compiled by D. E. Kizer
}

Al. Chemical composition

Cermets of UC have been successfully fabricated containing 60 to 80 volume per cent UC (67 to $92 \mathrm{w} / \mathrm{o})$ dispersed in molybdenum. (1)

\section{Effect of impurities}

No data available

B 1. Density (room temperature)

Calculated densities (external dimension divided by weight) range from 12.27 to $12.95 \mathrm{~g}$ per $\mathrm{cm}^{3}$ over a 60 to 90 volume per cent UC loading in the molybdenum cermet.

2. Density versus temperature

No data available

3. Uranium content

$0.952 \times$ w/o UC x density (see Fuel Comparison Table)

4. Liquidus temperature

No data available

5. Solidus temperature

No data available

6. Vopor pressure

No data available

7. Thermal expansion (linear) ${ }^{(2)}$

The mean linear thermal expansion for a 80 volume per cent UC-molybdenum cermet having a density 95 per cent of theoretical over the temperature range 20 to $950 \mathrm{C}$ was found to be 7.2 to $7.6 \times 10^{-6}$ per C. A 60 volume per cent UC-molybdenum cermet of 97 per cent of theoretical density was found to have a coefficient of 6.4 to $6.8 \times 10^{-6}$ per $C$ over the 20 to $950 \mathrm{C}$ temperature range.

\section{C1. Mardness (room temperature)}

No data available

\section{Hot hardness}

No data available

3. Ultimate tensile strength

No data available

4. Compressive yield strength $(3)$

See Table C4. 
TABLE C4. COMPRESSIVE MECHANICAL PROPERTIES FOR UC-MOLYBDENUM CERMETS (3)

\begin{tabular}{|c|c|c|c|c|c|}
\hline \multirow[b]{2}{*}{$\begin{array}{l}\text { UC Content, } \\
\text { volume per cent }\end{array}$} & \multirow{2}{*}{$\begin{array}{c}\text { Density, } \\
\text { per cent } \\
\text { of theoretical }\end{array}$} & \multirow{2}{*}{$\begin{array}{c}\text { Ultumate } \\
\text { Compressive } \\
\text { Strength, } 10^{3} \text { psi }\end{array}$} & \multirow{2}{*}{$\begin{array}{l}\text { Young's } \\
\text { Modulus, } \\
10^{6} \text { psi }\end{array}$} & \multicolumn{2}{|c|}{ Yield Strength, $10^{3} \mathrm{ps} 1$} \\
\hline & & & & $\begin{array}{c}0.1 \text { Per Cent } \\
\text { Offser }\end{array}$ & $\begin{array}{c}0.2 \text { Per Cent } \\
\text { Offset }\end{array}$ \\
\hline 60 & 95 & 139.5 & 28.8 & 114.5 & 113.8 \\
\hline 60 & 98 & 111.7 & 25.5 & 73.9 & 80.0 \\
\hline 80 & 95 & 95.1 & 27.8 & 93.5 & -- \\
\hline
\end{tabular}

5. Compressive strength ${ }^{(3)}$

See Table C4.

6. Creep strength

No data available

7. Young's modulus (3)

See Table C4.

8. Shear modulus

No data available

9. Bulk modulus

No data available

10. Poisson's ratio

No data available

11. Elongation

No data available

D1. Specific heat

No data available

2. Thermal conductivity $(3,4)$

See Figure D2.

E1. Electrical resistivity(5)

See Figure El.

F. Chemical properties

No data available

G. Irradiation properties

No data available 


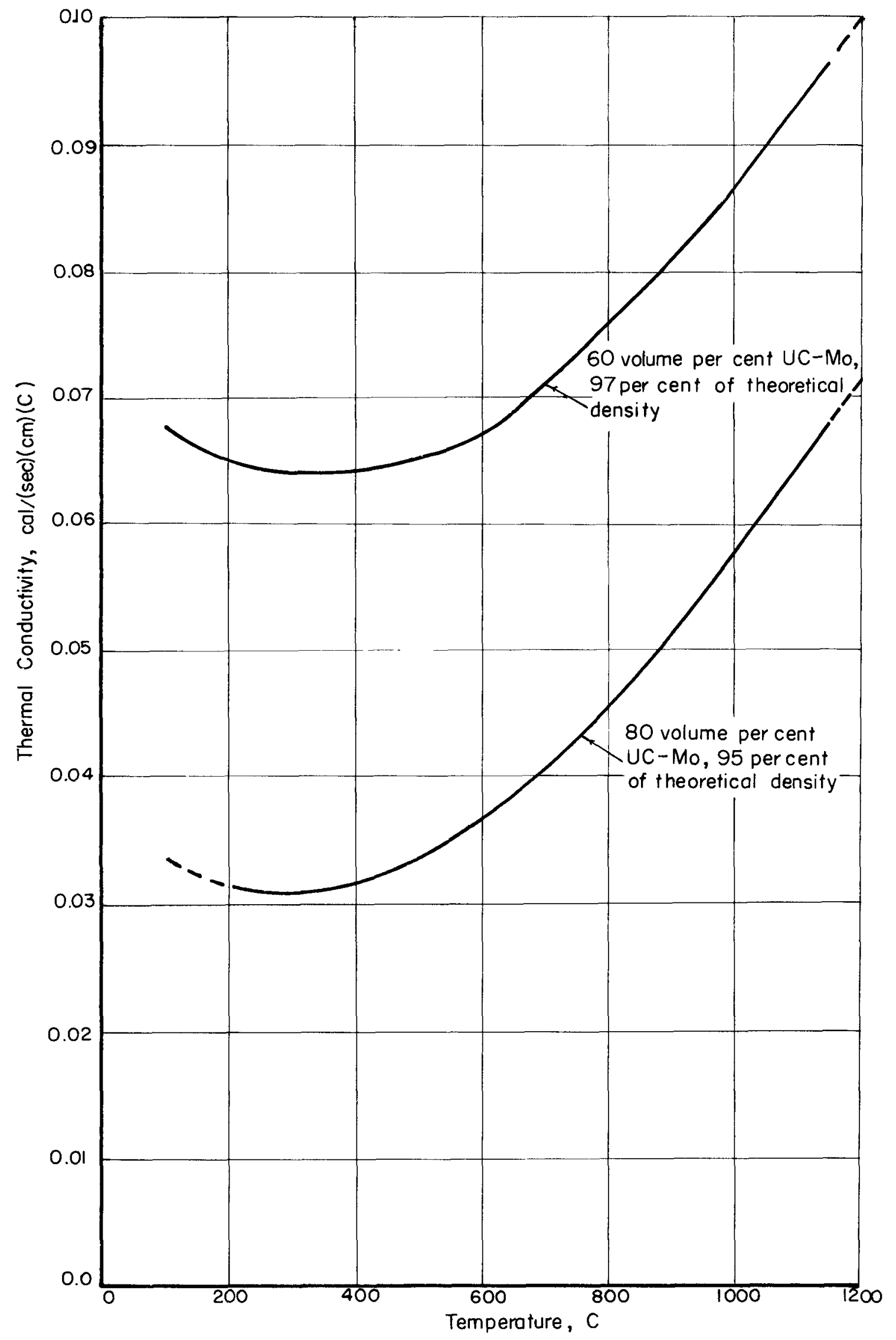

FIGURE D2. THERMAL CONDUCTIVITY OF UC CERMETS ${ }^{(3,4)}$ 


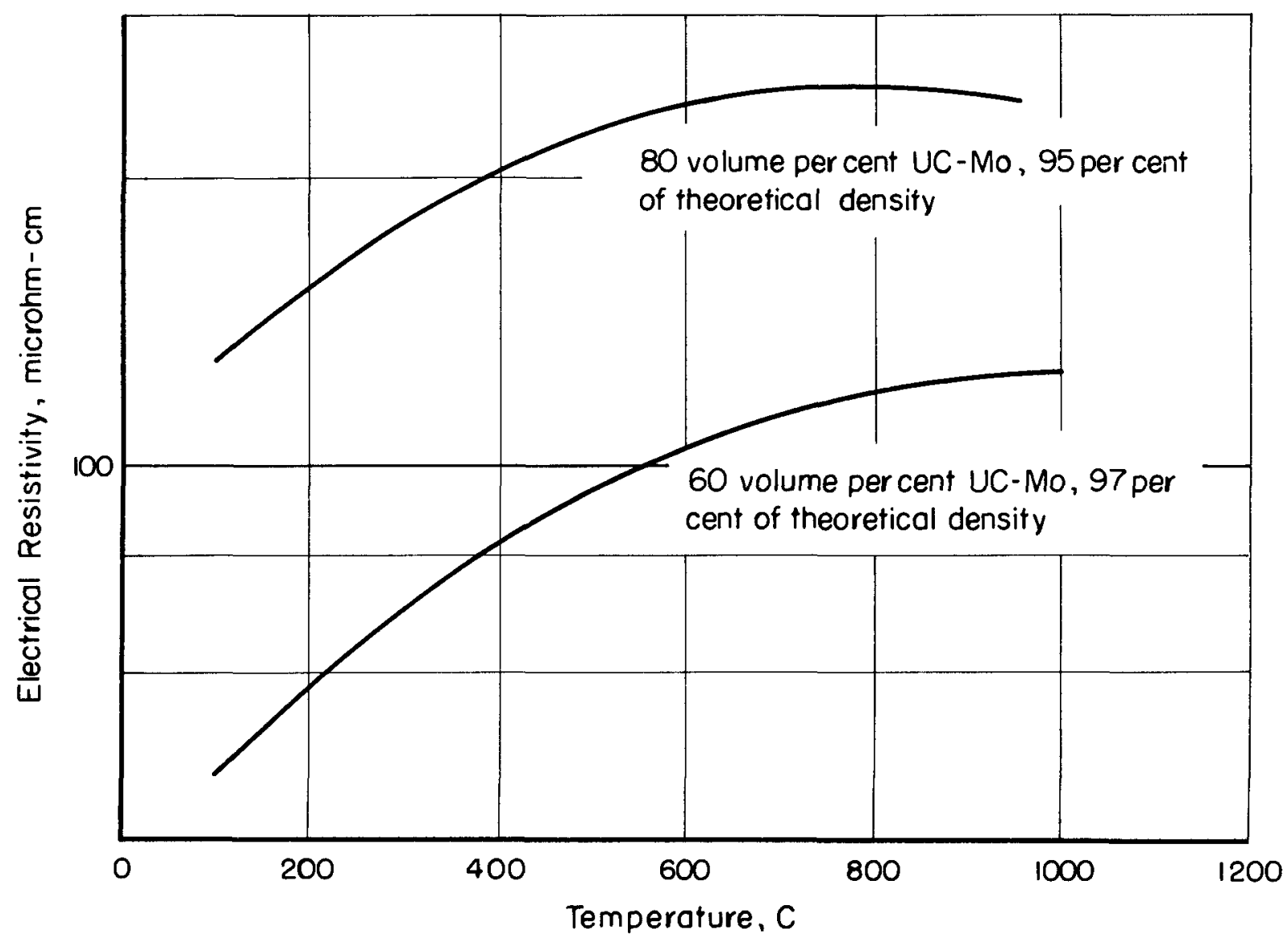

FIGURE EI. ELECTRICAL RESISTIVITY OF UC CERMETS ${ }^{(5)}$ 


\section{H. Peferences}

(1) Dayton, R. W., and Dickerson, R. F., "Progress Relating to Civilian Applications During March, 1962", BMl-1574 (April 1, 1962).

(2) Dayton, R. W. , and Dickerson, R. F., "Progress Relating to Civilian Applications During July, 1962", BMI-1589 (August 1, 1962)。

(3) Dayton, R. W., and Dickerson, R. F., "Progress Relating to Civilian Applications During June, 1962", BMI-1583 (July 1, 1962).

(4) Dayton, R. W., and Dickerson, R. F., "Progress Relating to Civilian Applications During May, 1962", BMI-1581 (June 1, 1962).

(5) Kizer, D. E., BMI, Unpublished Data. 
CERMETS

\section{UN CERMETS}

Compiled by D. E. Kizer

A1. Chemical composition (1)

UN cermets have been successfully fabricated containing 60 to 90 volume per cent UN dispersed in molybdenum, chromium, and Type 304 stainless steel, resulting in weight loadings ranging from 67 to $94 \mathrm{w} / \mathrm{o}$, depending on the matrix material used.

\section{Effect of impurities}

No data available

B1. Density (room temperature)

Calculated densities range from 11.57 to $13.5 \mathrm{~g} \mathrm{per} \mathrm{cm}^{3}$, depending on the volume loading of UN and matrix material used. Below are calculated densities of 80 volume per cent UN cermets with the three matrix materials used.

Matrix Metal

Molybdenum

Type 304 stainless steel

Chromium
Calculated
Density, g per $\mathrm{cm}^{3}$

13.5

13.0

12.9

\section{Density versus temperature}

No data available

3. Uranium content

$0.944 \times$ w/o UN $x$ density (see Fuel Comparison Table)

\section{Liquidus temperature}

No data available

5. Solidus temperature

No data available

6. Vapor pressure

No data available

7. Thermal expansion (1)

The mean linear therma 1-expansion coefficient measured for an 80 volume per cent UN-molybdenum cermet with a density 90.9 per cent of theoretical was 9.1 to $9.5 \times 10^{-6}$ per C over the temperature range 20 to 950 .

C1. Hardness (room temperature)

No data available

2. Modulus of rupture (2)

See Table C2. 
TABLE C2. MECHANICAL-PROPERTY VALUES OBTAINED ON MOLYBDENUM AND CHROMIUM CERMETS CONTAINING 80 VOLUME PER CENT UN $(2)$

\begin{tabular}{|c|c|c|c|c|c|c|}
\hline \multirow[b]{2}{*}{$\begin{array}{c}\text { Composition, } \\
\text { volume } \\
\text { per cent } \\
\end{array}$} & \multirow[b]{2}{*}{$\begin{array}{c}\text { Density, } \\
\text { per cent } \\
\text { of theoretical }\end{array}$} & \multirow[b]{2}{*}{$\begin{array}{c}\text { Dynamic } \\
\text { Modulus, } \\
10^{6} \text { psi }\end{array}$} & \multirow[b]{2}{*}{$\begin{array}{l}\text { Modulus of } \\
\text { Rupture, } \\
\text { psi }\end{array}$} & \multicolumn{3}{|c|}{ Compressive Properties } \\
\hline & & & & $\begin{array}{c}\text { Static } \\
\text { Modulus, } \\
10^{6} \mathrm{psi}\end{array}$ & $\begin{array}{l}0.2 \text { Per Cent Offset } \\
\text { Yield Strength, psi }\end{array}$ & $\begin{array}{c}\text { Ultirsate } \\
\text { Strength, } \\
\text { psi }\end{array}$ \\
\hline $\mathrm{Cr}-80 \mathrm{UN}$ & 90.1 & 25.19 & 18,100 & 27.2 & 104,800 & 131,000 \\
\hline Mo-80UN & 93.9 & 30.24 & 26,200 & 33.1 & 118,000 & 152,000 \\
\hline$\cdots$ & 93.9 & 29.66 & 24,900 & 30.2 & 110,000 & 140,000 \\
\hline
\end{tabular}

4. Compressive yield strength ${ }^{(2)}$

See Table C2.

5. Compressive strength(2)

See Table C2.

6. Creep strength

No data available

7. Young's modulus (2)

See Table C2.

8. Shear modulus

No data available

9. Bulk modulus

No data available

10. Poisson's ratio

No data available

11. Elongation

No data available

D1. Specific heat

No data available

2. Thermal conductivity $(3,4)$

See Figure D2.

E1. Electrical resistivity $(1,4)$

See Figure El.

F. Chemical properties

No data available

G. Irrodiation properties

No data available 


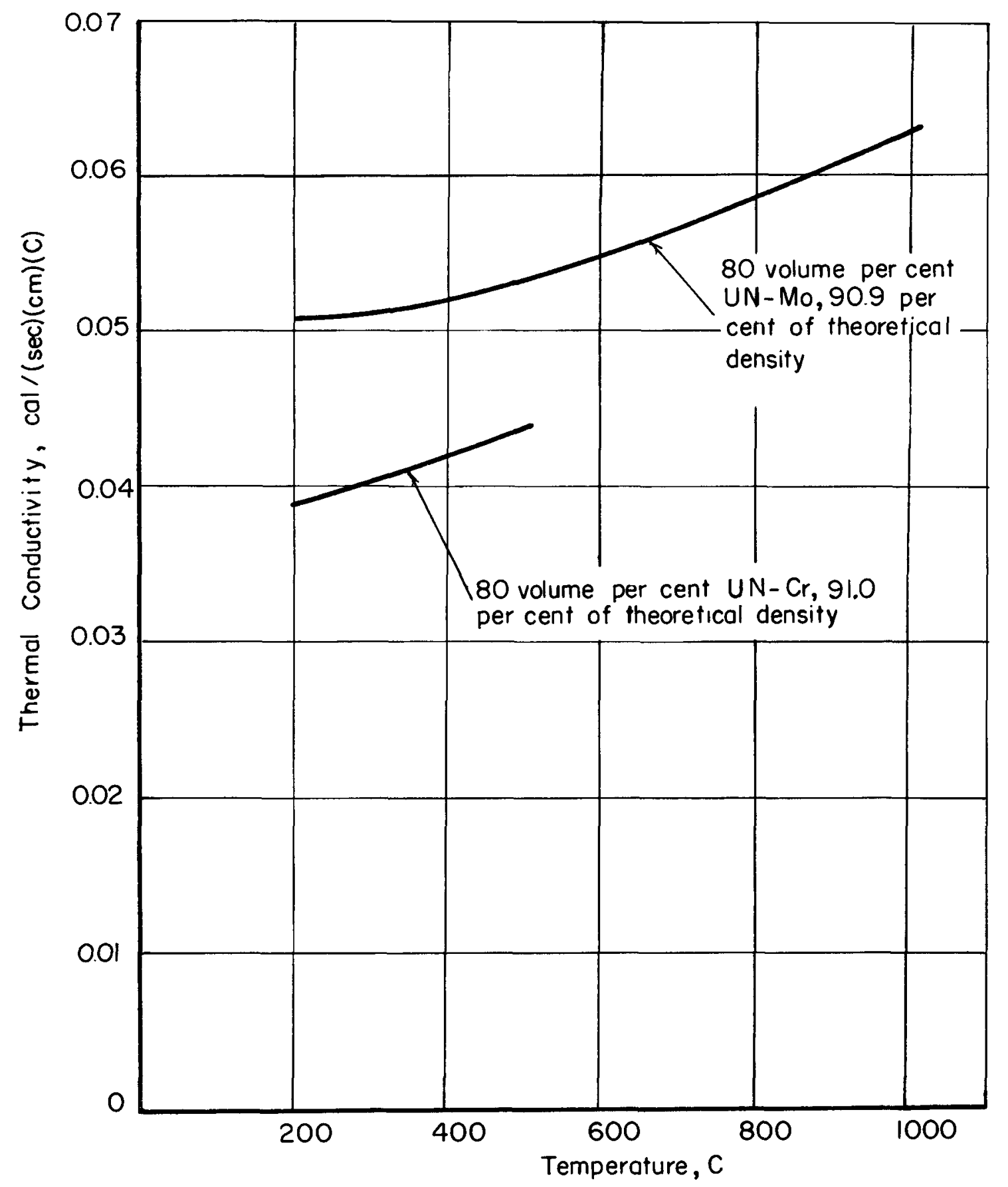

FIGURE D2. THERMAL CONDUCTIVITY OF UN CERMETS 


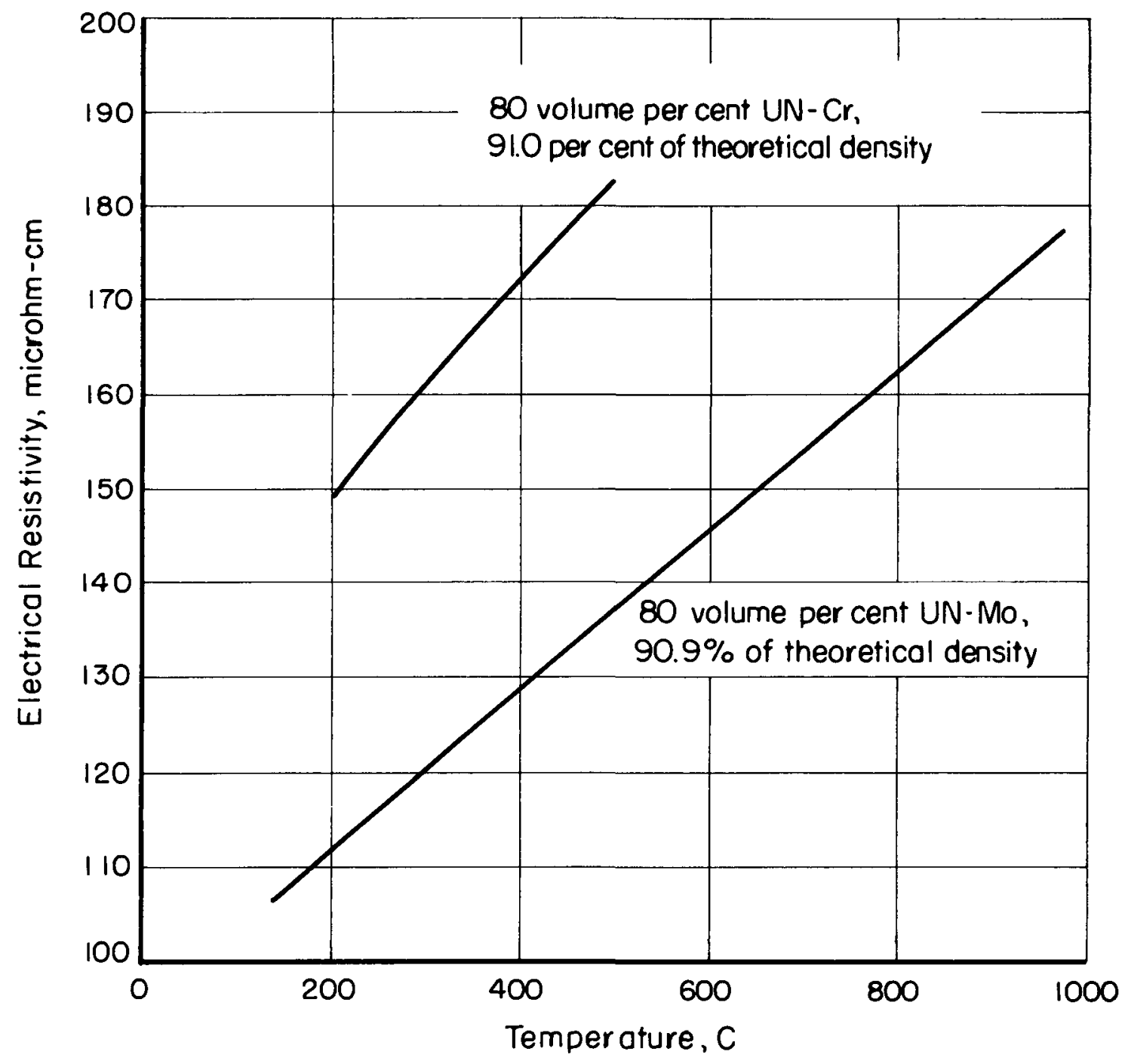

FIGURE EI. ELECTRICAL RESISTIVITY $(1,4)$ 
CERMETS

\section{H. References}

(1) Kizer, D. E. , BMI, Unpublished Data.

(2) Dayton, R. W., and Dickerson, R. F., "Progress Relating to Civilian Applications During April, 1962", BMI-1577 (May 1, 1962).

(3) Dayton, R. W. , and Tipton, C. R., Jr., "Progress Relating to Civilian Applications During May, 1961", BMI-1518 (June 1, 1961).

(4) Dayton, R. W., and Tipton, C. R., Jr., "Progress Relating to Civilian Applications During August, 1961", BMI-1541 (September 1, 1961). 


\title{
$\mathrm{UO}_{2}$ CERMETS
}

\author{
Compiled by D. Kizer
}

A1. Chemical composition (1)

Cermets of $\mathrm{UO}_{2}$ have been successfully fabricated containing 60 to 90 volume per cent $\mathrm{UO}_{2}$ dispersed in matrix materials of molybdenum, chromium, niobium, and Type $302 \mathrm{~B}$ stainless steel, resulting in a weight loading of $\mathrm{UO}_{2}$ between 61 and $94 \mathrm{w} / \mathrm{o}$, depending on the matrix material used.

3. Effect of impurities

No data available

B1. Density (room temperature)

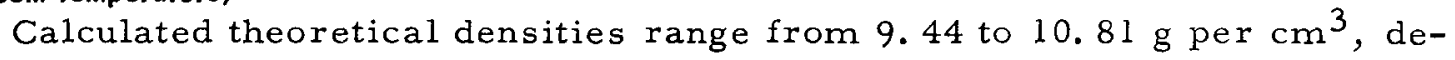
pending on the volume loading of $\mathrm{UO}_{2}$ and the matrix material used. Below are calculated densities of 80 volume per cent $\mathrm{UO}_{2}$ cermets with the four matrix materials.

Matrix Metal

Molybdenum

Niobium

Chromium

Type $302 \mathrm{~B}$ stainless steel
Calculated

Density, $\mathrm{g}$ per $\mathrm{cm}^{3}$

10.81

10.47

10. 20

10.24

2. Density versus temperoture

No data available

3. Uranium content

$0.882 \mathrm{x}$ w/o $\mathrm{UO}_{2} \mathrm{x}$ density (see Fuel Comparison Table).

4. Liquidus temperature

No data available

\section{Solidus temperature}

No data available

6. Vapor pressure

No data available 
$\mathrm{UO}_{2}$

CERMETS

7. Thermal expansion $(1)$

Thermal-expansion data have been reported for chromium-, molybdenum-, and Type $302 \mathrm{~B}$ stainless steel- $\mathrm{UO}_{2}$ cermets:

\begin{tabular}{l} 
Nominal \\
UO2 Content, \\
Volume \\
per cent \\
\hline
\end{tabular}

80

80

80

70

70

\begin{tabular}{l} 
Matrix Metal \\
\hline Molybdenum \\
Chromium \\
Type 302B stainless \\
Type 302B stainless \\
Molybdenum
\end{tabular}

Thermal-

\begin{tabular}{c} 
Cermet \\
Density, \\
per cent \\
of theoretical \\
\hline
\end{tabular}

94.4

97.1

98.4

97.0

91.7
Expansion

Coefficient (20-950 C), $10^{-6}$ per $\mathrm{C}$

\section{8 to 9.2}

10.2 to 10.4

11.2 to 11.5

11.3 to 11.7

7.9 to 8.3

C1. Hardness

No data available

\section{Hot hardness}

No data available

3. Modulus of rupture $\mathrm{e}^{(1)}$

Modulus of rupture has been measured on chromium-, molybdenum-, and Type $302 \mathrm{~B}$ stainless -80 volume per cent $\mathrm{UO}_{2}$ cermets:

Matrix Metal
Molybdenum
Type $302 B$ stainless

Chromium

\author{
Cermet Density, \\ per cent of theoretical
}

91.6

90.7

88.5

96.5

97. 4

94.4

96.5

97. 0

95.5
Modulus of

Rupture, psi

12,000

13,800

12,100

18,100

17,200

13,300

22,500

20,600

21,600

\section{Compressive yield strength $(1)$}

See Figures C4a, C4b, and C4c.

5. Compressive strength $(1)$

See Figures C4a, C4b, and C4c.

6. Creep strength

No data available

7. Young's modulus(1)

See Figures C4a, C4b, and C4c.

\section{Shear modulus}

No data available 


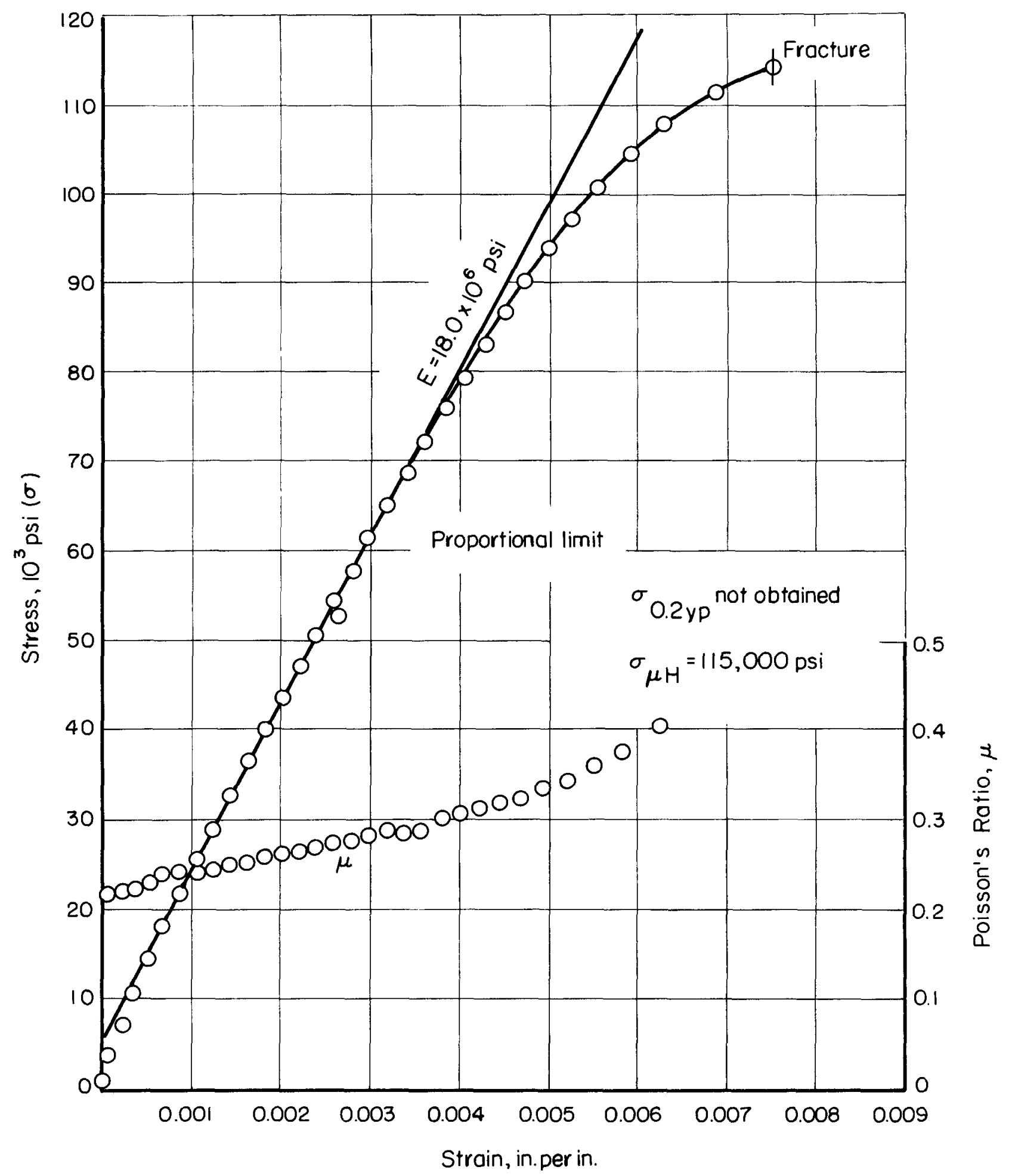

FIGURE C4O. COMPRESSIVE TEST ON AN 80 VOLUME PER CENT UO ${ }_{2}^{-}$ STAINLESS STEEL CERMET WITH A DENSITY 96.5 PER CENT OF THEORETICAL DENSITY 


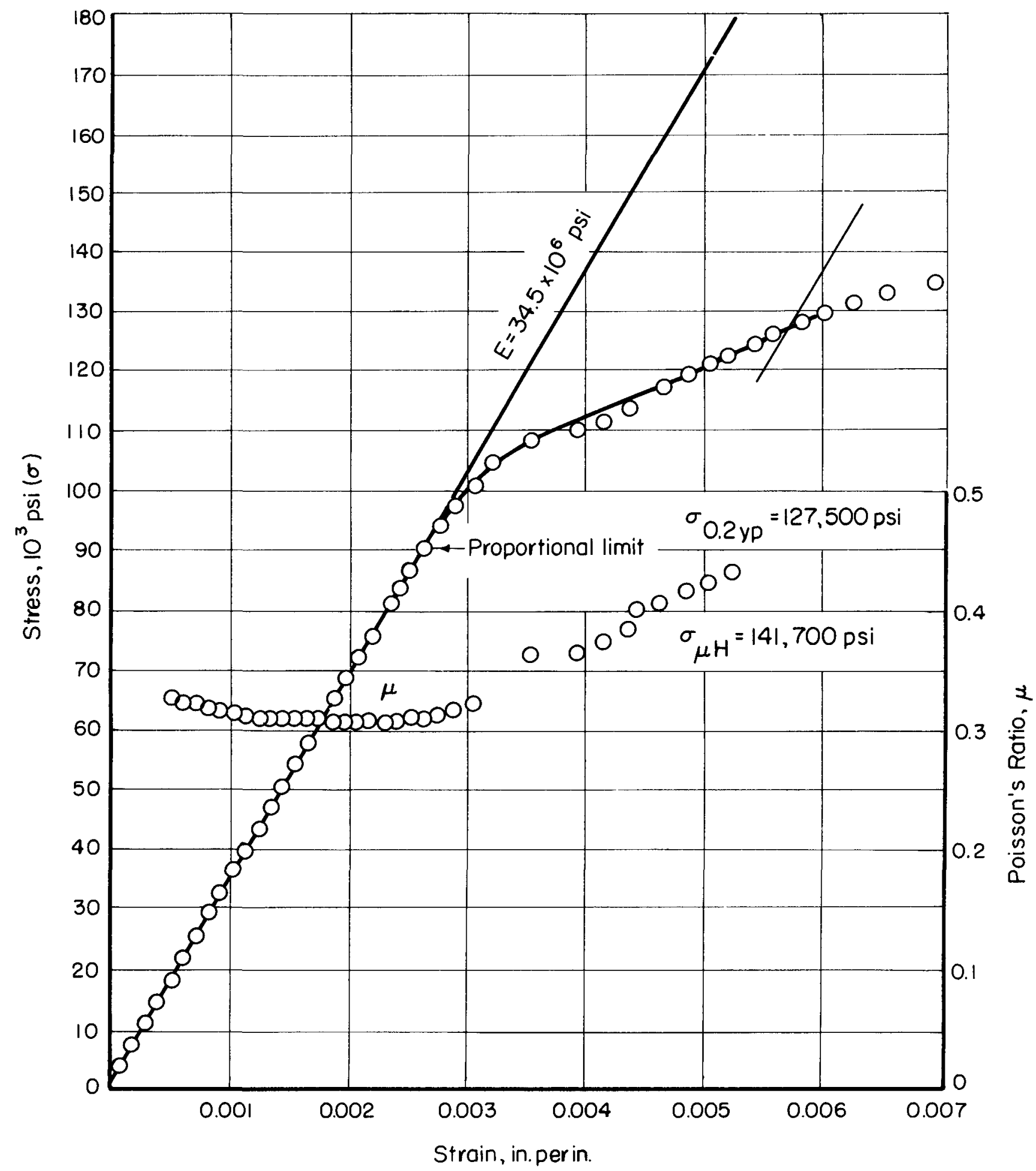

FIGURE C4b. COMPRESSIVE TEST ON AN 80 VOLUME PER CENT UO ${ }_{2}^{-}$ CHROMIUM CERMET WITH A DENSITY 97.0 PER CENT OF THEORETICAL ${ }^{(1)}$ 


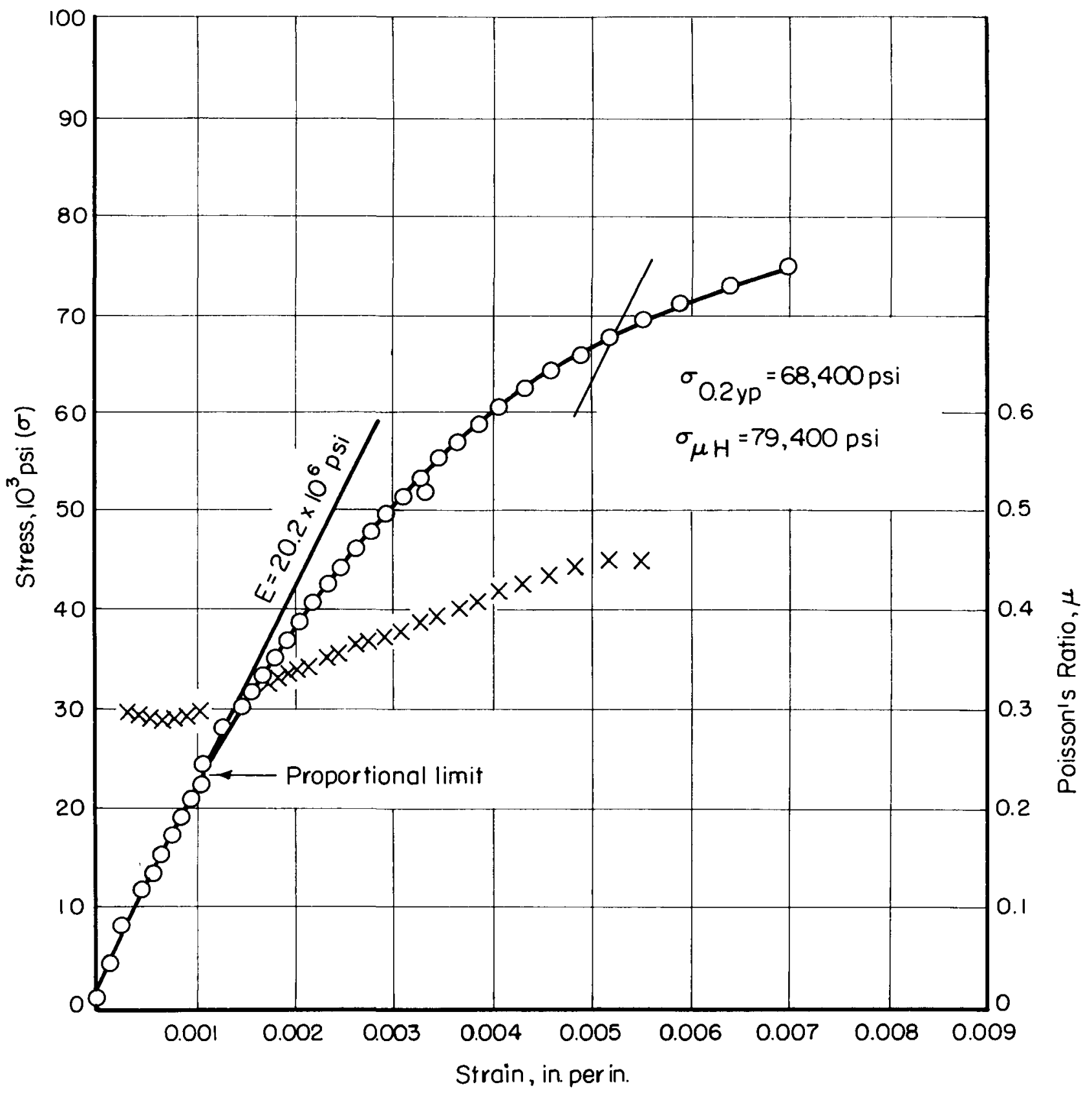

FIGURE C4C. COMPRESSIVE TEST ON AN 80 VOLUME PER CENT UO ${ }_{2}^{-}$ MOLYBDENUM CERMET WITH A DENSITY 90.7 PER CENT OF THEORETICAL (1) 
$\mathrm{UO}_{2}$

CERMETS

9. Bulk modulus

No data available

10. Poisson's ratio (1)

See Figures C4a, C4b, and C4c.

11. Elongation

No data available

D1. Specific heat

No data available

2. Thermal conductivity (1)

See Figure D2.

E1. Electrical resistivity (1)

See Figure El.

FI. Reaction of base material $(2,3)$

a. If the structure is not defected one would expect the reaction to be similar to the reaction with the base metal used until such time as the $\mathrm{UO}_{2}$ was exposed.

b. A 0.006-in. cladding-defected hole has been drilled into a capsule of UO2 and a capsule of chromium-80 volume per cent $\mathrm{UO}_{2}$ to compare oxidation at $1750 \mathrm{~F}$ in air. Both cores were of equal volume and had densities approximately 96 per cent of theoretical. Following is a tabulation of the oxidation of $\mathrm{UO}_{2}$ determined after 24 and $144 \mathrm{hr}$ at temperature.

\begin{tabular}{lcc} 
& \multicolumn{2}{c}{ Oxidation of $\mathrm{UO}_{2}$, per cent } \\
\cline { 2 - 2 } $\mathrm{UO}_{2}$ & $\frac{\text { After } 24 \mathrm{Hr}}{48.2}$ & 60.6 \\
$\begin{array}{l}\text { Chromium-80 volume } \\
\text { per cent } \mathrm{UO}_{2} \text { cermet }\end{array}$ & 2.5 & 7.7
\end{tabular}

\section{Reactions with claddings or structural materials}

Any cladding that is compatible with $\mathrm{UO}_{2}$ and the matrix metal used should be suitable from a compatibility standpoint.

G1. Dimensional stability ${ }^{(4)}$

A 95 to 96 per cent dense 80 volume per cent UO2-niobium cermet clad with niobium irradiated at an average surface and center temperature of 925 and $1400 \mathrm{C}$ (peak 1000 and $1500 \mathrm{C}$ ), respectively, to a burnup of approximately 3 per cent of the total uranium atoms $\left(7.0 \times 10^{20}\right.$ fissions per $\left.\mathrm{cm}^{3}\right)$ showed a 1.4 per cent decrease in density and 0.2 per cent growth in length and 0.7 per cent in diameter. 


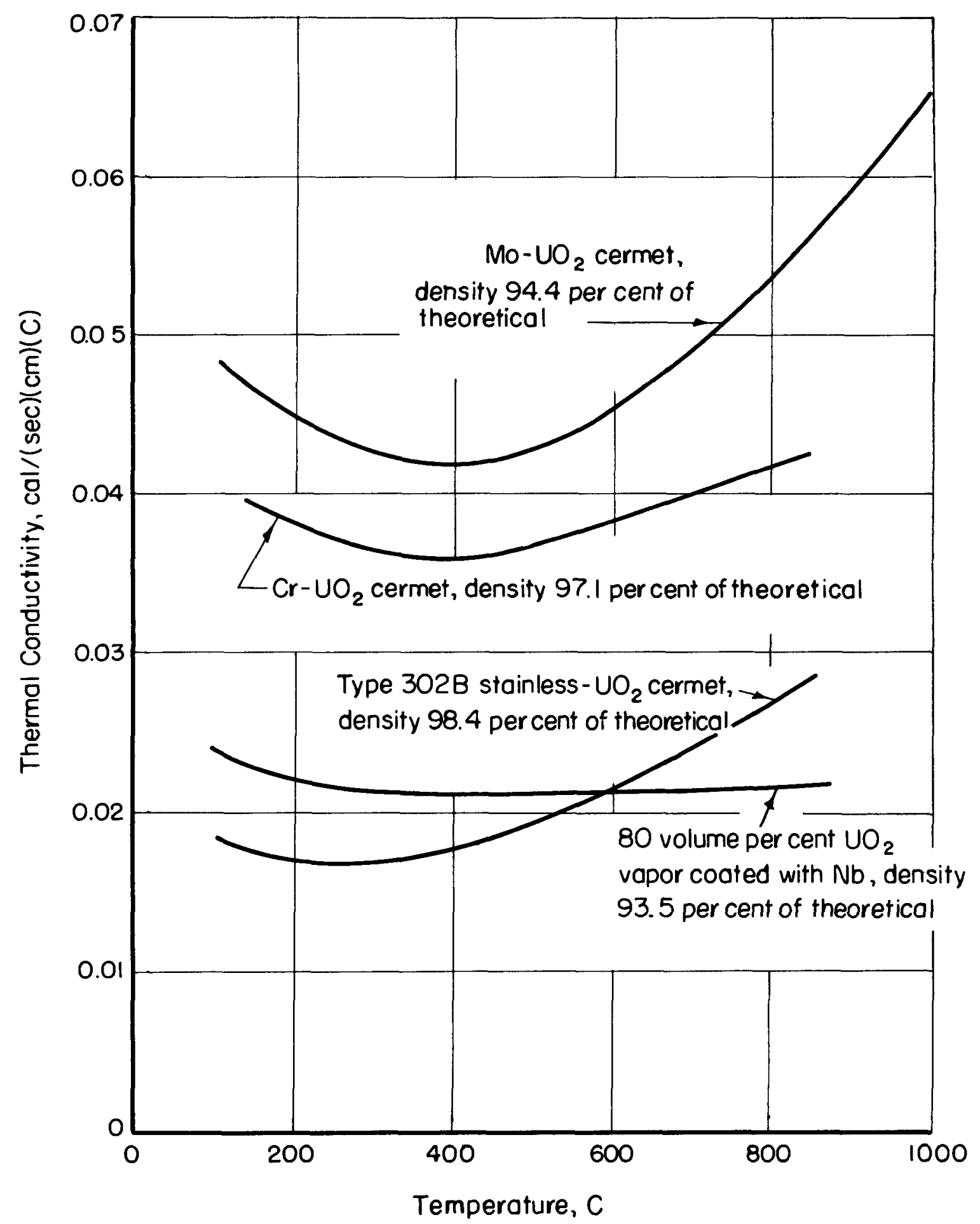

FIGURE D2. THERMAL CONDUCTIVITY OF $\mathrm{OO}_{2}$ CERMETS $^{(1)}$ 


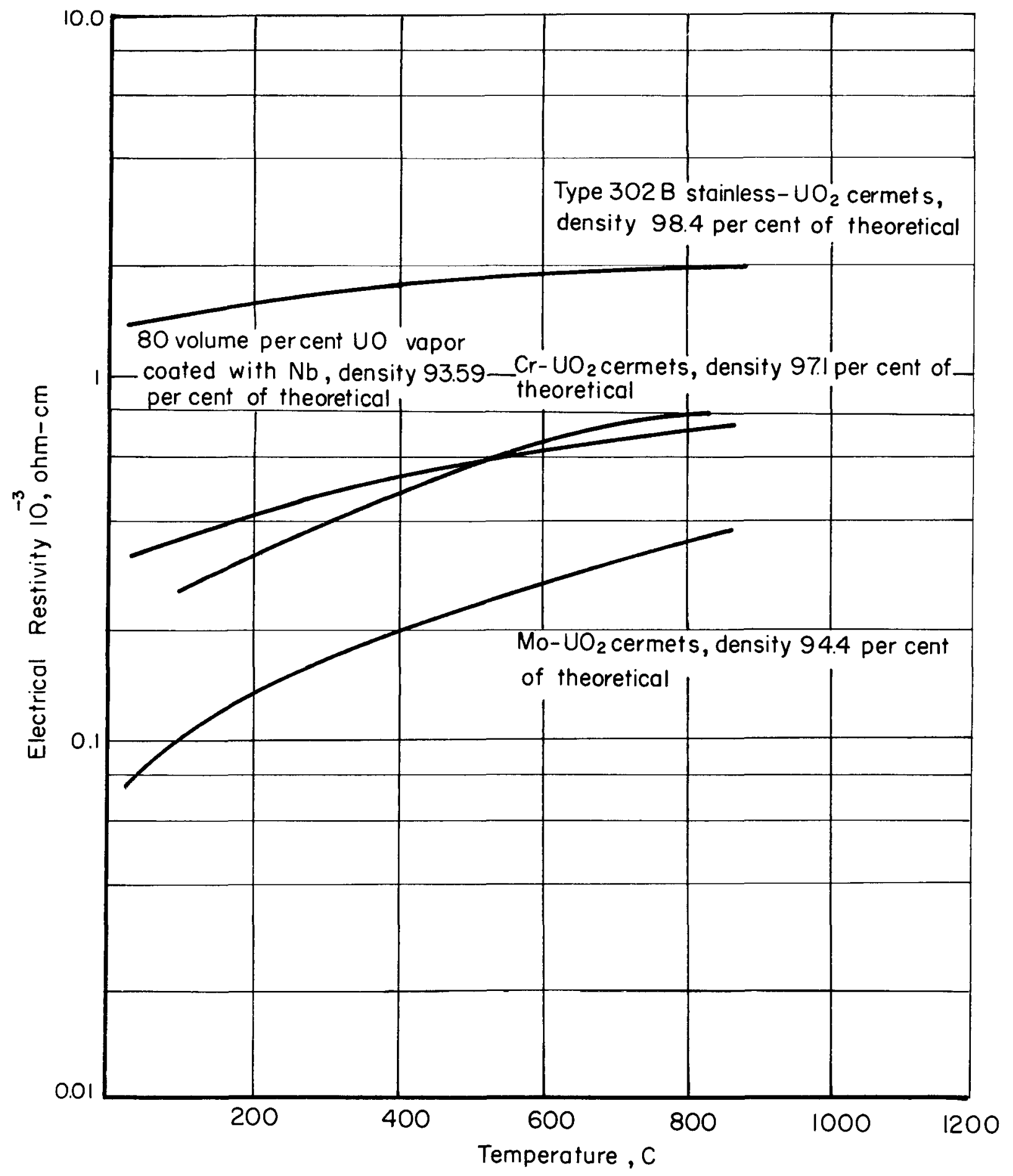

FIGURE EI. ELECTRICAL RESISTIVITY OF 80 VOLUME PER CENT $\mathrm{UO}_{2}$ CERMETS $S^{(1)}$ 
2. Fission gas release

No data available

3. Swelling temperature data

See Gl.

4. Unusual nuclear properties

No data available

5. Property changes as a result of irradiation

No data available

H. References

(1) Paprocki, S。 J., Keller, D. L。, Cunningham, G. W. , and Kizer, D. E. , "Preparation and Properties of $\mathrm{UO}_{2}$ Cermet Fuels", BMI-1487

(December 19, 1960).

(2) Paprocki, S. J., Keller, D. L., and Pardue, W. M. , "Study of Experimental Fuel Bodies Made From Alumina-Coated $\mathrm{UO}_{2}$ Particles", BMI- 1586 (July 16, 1962).

(3) Kizer, D. E., BMI, Unpublished Data.

(4) Lozier, E. D. , BMI, Unpublished Data. 
-

•. 
COATED-PARTICLE FUELS 


\title{
COATED-PARTICLE FUEL MATERIALS
}

\author{
Compiled by J. H. Oxley
}

Extensive property data on coated-particle fuels are unavailable owing to the relatively recent development of these materials. However, since this type of fuel holds considerable promise for gas-cooled reactors, it does appear desirable to summarize and tentatively interpret the limited data available. Therefore, the current status on the manufacture, properties, and performance of these new fuels is discussed in this section.

Sufficient information has been obtained for preliminary design purposes.

Preparation and Properties of Coated-Particle Fuels

M. F. Browning

Coatings of $\mathrm{Al}_{2} \mathrm{O}_{3}$, pyrolytic carbon, $\mathrm{BeO}$, and $\mathrm{MgO}$ on $\mathrm{UO}_{2}$ particles are being evaluated to determine their utility as fission-product and reaction barriers. Pyrolytic-carbon coatings on $\mathrm{UC}_{2}$ and $\mathrm{UC}$ particles are also being evaluated for this purpose.

Chemical vapor-deposition reactions in fluidized beds of the particles are being used to apply coatings to particles 50 to $600 \mu$ in diameter. Larger particles up to $1 / 8$ in. in diameter and materials difficult to fluidize have been agitated by vibrating and/or tumbling during the coating operation. Although present experience has been limited mainly to the coating of particles in the $50-\mu$ to $1 / 8$-in.-diameter size range, there is reason to believe that this range can be extended. In general, the maximum coating thickness which can be applied is governed only by economic considerations.

Alumina and beryllia are formed by the hydrolysis of their respective chlorides with either steam or a $\mathrm{CO}_{2}: \mathrm{H}_{2}$ mixture as the hydrolyzing agent. The steam hydrolysis of $\mathrm{MgI}_{2}$ is used for depositing $\mathrm{MgO}$. In addition, the formation of the se oxides by the thermal decomposition of metal organics has received limited attention. Pyrolytic carbon is formed generally by the decomposition of $\mathrm{C}_{2} \mathrm{H}_{2}$ and $\mathrm{CH}_{4}$, but the use of other hydrocarbons has been investigated.

Alumina coatings of near theoretical density deposited at a temperature of $1000 \mathrm{C}$ have good integrity and consist of small crystallites of alpha alumina with an average size of $0.3 \mu$ dispersed in an amorphous matrix. Coatings deposited at temperatures from 500 to $700 \mathrm{C}$ are porous, of lower density, and completely amorphous, but become crystalline on heat treating at temperatures of about $1000 \mathrm{C}$ and above. Coatings prepared at $1400 \mathrm{C}$ are highly crystalline, but exhibit a coating integrity inferior to that of the $1000 \mathrm{C}$ coatings. The hardness of the coatings prepared at $1000 \mathrm{C}$ and above is equal to or higher than that of sapphire (2200-2500 KHN, 50-g load).

The oxygen/uranium ratio of both porous and dense $\mathrm{UO}_{2}$ substrates coated with $\mathrm{Al}_{2} \mathrm{O}_{3}$ under various conditions has tentatively been found to be 2.002 , even though the ratio before coating was as high as 2.039 . 
Beryllia coatings prepared at $1400 \mathrm{C}$ are of near theoretical density, are very crystalline, and exhibit good integrity. Coatings deposited at temperatures between 800 and $1100 \mathrm{C}$ are less crystalline and porous. The hardness of the $1400 \mathrm{C}$ coatings is essentially equal to that of single-crystal BeO (1200-1400 KHN, 50-g load).

Magnesia coatings deposited at $1400 \mathrm{C}$ are relatively transparent, dense, and void-free. Coatings prepared at 1100 and $800 \mathrm{C}$ are less transparent and appear to contain submicron pores. The hardness of the coatings is not significantly affected by coating temperature and is slightly less than that of fused $\mathrm{MgO}$ (925-975 $\mathrm{KHN}, 50-\mathrm{g}$ load). The differential between the thermal expansion of $\mathrm{UO}_{2}$ and $\mathrm{MgO}$ can result in cracked coatings, but this problem has been essentially overcome by the use of porous $\mathrm{UO}_{2}$ or the incorporation of an annular void in the particle. All $\mathrm{MgO}$ coatings have failed to withstand oxidation at $1100 \mathrm{C}$. Recent investigations have tentatively indicated that oxygen diffusion is the major cause of failure.

Py rolytic-carbon coatings with good integrity have been applied to fuel particles at temperatures of 950 to $2000 \mathrm{C}$. The PyC structure of a $1400 \mathrm{C}$ coating varies from columnar to laminar, depending on the deposition rate. Coatings applied at under $10 \mu$ per $h r$ are definitely columnar and those deposited above $30 \mu$ per $\mathrm{hr}$ are decidedly laminar. The density of the PyC coatings prepared by the fluidized-bed techniques decreases from $1.99 \mathrm{~g}$ per $\mathrm{cm}^{3}$ at a coating temperature of $950 \mathrm{C}$ to a minimum value of approximately $1.50 \mathrm{~g}$ per $\mathrm{cm}^{3}$ at $1500 \mathrm{C}$ and then increases to a density of $1.94 \mathrm{~g}$ per $\mathrm{cm}^{3}$ at a temperature of $1800 \mathrm{C}$. The crystallite size of PyC coatings prepared in a fluidized bed varies with coating temperature and type (columnar or laminar). The c-axis crystallite size of laminar coatings deposited at $1400 \mathrm{C}$ and below is about $25 \mathrm{~A}$ and increases to $150 \mathrm{~A}$ at a coating temperature of $1800 \mathrm{C}$. Columnar coatings prepared at below $1400 \mathrm{C}$ have a crystallite size of about $40 \mathrm{~A}$.

\section{Graphite-Matrix Elements Containing Coated-Particle Fuels}

\section{C. Brockway}

The development of coated-particle fuels is current, thus property data on dispersions of such fuel in graphite are very limited. However, certain generalizations concerning expected properties are possible. Many properties of fueled graphite should be similar whether coated or uncoated fuel is the dispersed phase. This will be true if comparison is made on the basis of equal volume loading, since particle coatings can add appreciably to the fuel volume. The primary differences expected of graphite fueled with coated-particle fuel versus uncoated fuel are: (1) high fission-product retention, (2) absence of fission-fragment damage to the matrix, (3) altered nuclear properties dependent upon the type and amount of coating material, and (4) operating-temperature limits dependent upon the type of coating as well as the fuel. For a given fuel loading, composite properties will be altered by the replacement of matrix volume with coating. Also, matrix properties or geometries may differ from those of uncoated fuel dispersions because of fabrication requirements imposed by coated fuel, as discussed in the following paragraph.

Graphite fueled with coated-particle fuel promises outstanding fission-product retention, but only if the fuel is undamaged during dispersion in the matrix graphite. Early work by several investigators $(1-3)$ has shown that coated-particle fuels may be 
readily damaged through impact or localized stresses. The dispersion and forming methods usually employed with uncoated fuels are damaging to coated-particle fuels. However, studies directed toward the solution of this dispersion problem have been successful. A hot-press technique ${ }^{(4)}$ has been sufficiently successful in minimizing fuel damage during forming of graphite compacts fueled with $\mathrm{PyC}$-coated $(\mathrm{Th}, \mathrm{U}) \mathrm{C}_{2}$ that it is being used to prepare HTGR prototype fuel elements. A second method(5), fuel dispersion by matrix pelletizing, has permitted the dispersion of $\mathrm{Al}_{2} \mathrm{O}_{3}$-coated $\mathrm{UO}_{2}$ in graphite without evidence of fuel damage. Such pelletizing also permits a closer approach to an ideal fuel-particle dispersion than previously possible.

Property data typical of HTGR graphite-matrix fuel compacts are given in Table 1. The values listed represent the most complete property data presently available for graphite matrices in which coated-particle fuels have been successfully incorporated. It should be noted that in these HTGR fuel compacts it is not essential that the dispersed fuel be completely free from damage. The property variations as a function of coatedparticle fuel loading were not reported except that fuel particle size (50 to $500 \mu)$ and fuel loading ( 0 to $22 \mathrm{w} / 0$ thorium plus uranium) had little, if any, effect on the the rmal expansion of fueled compacts. These data should not be interpreted as being generally representative of properties of all graphite matrices in which coated-particle fuels may be incorporated.

TABLE 1. TYPICAL PROPERTIES OF GRAPHITE-MATRIX FUEL COMPACTS(4)

\begin{tabular}{|c|c|}
\hline Graphite density & $1.90-1.95 \mathrm{~g}$ per $\mathrm{cm}^{3}$ \\
\hline \multicolumn{2}{|l|}{ Crushing strength } \\
\hline Transverse & $8500 \mathrm{psi}$ \\
\hline Longitudinal & $7500 \mathrm{psi}$ \\
\hline \multicolumn{2}{|l|}{ Thermal expansion at $1000 \mathrm{C}$} \\
\hline Transverse & $7.5 \times 10^{-6}$ per $C$ \\
\hline Longitudinal & $2.25 \times 10^{-6}$ per $C$ \\
\hline $\begin{array}{l}\text { Thermal conductivity at } 2000 \mathrm{C} \\
\text { (radial) }\end{array}$ & $0.3 \mathrm{w} /(\mathrm{cm})(\mathrm{C})[0.07 \mathrm{cal} /(\mathrm{cm})(\mathrm{sec})(\mathrm{C})]$ \\
\hline Electrical resistivity & $3.5 \times 10^{-3} \mathrm{ohm}-\mathrm{cm}$ \\
\hline Permeability (He at 1 atm) & $2 \times 10^{-3} \mathrm{~cm}^{2}$ per sec \\
\hline Pore structure & $\begin{array}{l}<1 \text { per cent of porosity due to pores }>1 \mu \\
\text { in diameter }\end{array}$ \\
\hline Radiation stability & $\begin{array}{l}\leq 0.1 \text { per cent contraction after } 6 \times 1019 \\
\text { fissions per } \mathrm{cm}^{3} \text { at } 1100-1500 \mathrm{C}\end{array}$ \\
\hline
\end{tabular}

In-Pile Evaluations of Coated Particle Fuels

N. E. Miller and R. L. Ritzman

Ceramic-coated oxide- and carbide-base fuel particles prepared by Battelle are being evaluated for fission-gas-release characteristics $(6)$, and coated carbide fuel particles supplied by commercial suppliers are being evaluated by ORNL(7). Irradiation 
PART.

studies of pyrolytic-carbon-coated $(\mathrm{U}, \mathrm{Th}) \mathrm{C}_{2}$ particles are also being carried out by General Atomic. However, the primary purpose of the GA coatings is to prevent hydrolysis of the fuel during fabrication, and fission-product retention is of secondary importance. Table 2 contains a summary of the fission-gas-release data from sweepcapsule experiments conducted on these types of fuel materials at temperatures below $1200 \mathrm{C}$.

Alumina-coated $\mathrm{UO}_{2}$ particles have shown a high degree of fission-gas retention at temperatures between 500 and $1100 \mathrm{C}$. At temperatures below $500 \mathrm{C}$, however, a rapid and severe coating failure occurs. The performance of the Lot BMI-715A material in the CFP-S-9 capsule experiment illustrates the temperature dependence of fission-gas-release characteristics of the alumina-coated fuels. In this experiment the $R / B$ (ratio of the release rate to production rate) for xenon-133 rapidly changed from the order of $10^{-9}$ to $10^{-4}$ as the temperature was reduced from $645 \mathrm{C}$ to $470 \mathrm{C}$ and increased still more as the temperature was changed to $295 \mathrm{C}$.

In the one experiment conducted with beryllia-coated $\mathrm{UO}_{2}$ at low temperature, the initial release fractions were in the order of $10^{-5}$ and showed little change up to 2 per cent uranium burnup. It is not definite whether this sample contained particles with cracked coatings prior to the irradiation or whether cracking occurred during the first few minutes of the irradiation.

The pyrolytic-carbon-coated $\mathrm{UC}_{2}$ and $\mathrm{UO}_{2}$ particles prepared by Battelle have shown initial good gas retention with a gradual increase in fission-gas release occurring as the irradiation proceeds. The CF P-S -9 experiment showed no apparent relation between coating failure and operating temperature. The overlay of pyrolytic carbon in the Lot $736 \mathrm{~B}$ material resulted in cracking the $\mathrm{Al}_{2} \mathrm{O}_{3}$ coating, so the data from the CFP-S-10 experiment are representative of release from pyrolytic-carbon coatings protected from fission recoils from the fuel-particle surface.

Carbon-coated $\mathrm{UC}_{2}$ particles prepared by NCC, HTM, and $3 \mathrm{M}$ a re being evaluated at ORNL in sweep-capsule experiments at $820 \mathrm{C}$ and compared with uncoated $\mathrm{UC}_{2}$ particles. Of these experimental materials, the NCC sample has shown better fissiongas-retention characteristics than any carbon-coated particles evaluated.

Postirradiation Evaluation of Coated-Particle Fuels

R. J. Burian and R. L. Ritzman

Various types of coated particles have been evaluated after irradiation to determine the fission-product-retention properties of the coatings. Different combinations of pyrolytic carbon and high- and low-density $\mathrm{Al}_{2} \mathrm{O}_{3}$ coatings have been deposited on high- and low-density $\mathrm{UO}_{2}$ and $\mathrm{UC}_{2}$ particles. Parameters studied include the size, porosity, and material of the fuel particle, the thickness, porosity, and material of the coating, and the effect of heat treatment before irradiation, the irradiation temperature, the fuel burnup, and the support from a matrix on the performance of the coatings. 
TABLE 2. SUMMARY OF FISSION -GAS-RELEASE DATA FROM COATED-PARTICLE FUELS IN SWEEP-GAS EXPERIMENTS

\begin{tabular}{|c|c|c|c|c|c|c|c|c|c|c|c|c|}
\hline \multicolumn{6}{|c|}{ Specimen Description } & \multirow{3}{*}{$\begin{array}{c}\text { CFP } \\
\text { Irradiation } \\
\text { Capsule }\end{array}$} & \multirow{3}{*}{$\begin{array}{c}\text { Nominal } \\
\text { Irradiation } \\
\text { Temperature, } \\
\text { C }\end{array}$} & \multirow{3}{*}{$\begin{array}{l}\text { A ccumulated } \\
\text { Irradiation } \\
\text { Time, hr }\end{array}$} & \multirow{3}{*}{$\begin{array}{c}\text { Uranium } \\
\text { Burnup, } \\
\text { a/o }\end{array}$} & \multicolumn{3}{|c|}{$\mathrm{R} / \mathrm{B}^{(\mathrm{b})}$} \\
\hline \multirow[b]{2}{*}{ Lot } & \multicolumn{2}{|c|}{ Fuel } & \multicolumn{2}{|c|}{ Coating $(a)$} & \multirow[b]{2}{*}{ Matrix } & & & & & $\mathrm{Kr}^{85 \mathrm{~m}}, \mathrm{Kr}^{87}$ & & \\
\hline & $\overline{\text { Size, } \mu}$ & Kind & Thickness, $\mu$ & Kind & & & & & & and $\mathrm{Kr}^{88}(\mathrm{c})$ & $\mathrm{Xe}^{135}$ & $\mathrm{Xe}^{133}$ \\
\hline \multirow{2}{*}{$\mathrm{BMI}-4 \mathrm{E}$} & 127 & $\mathrm{UO}_{2}$ & 42 & $\mathrm{Al}_{2} \mathrm{O}_{3}$ & Graphite & CFP-S - 5 & 1070 & 47 & 0.2 & $4 \times 10^{-6}$ & $1 \times 10^{-6}$ & $5 \times 10^{-6}$ \\
\hline & & & & & & & 1070 & 256 & 0.8 & $3 \times 10^{-6}$ & $4 \times 10^{-6}$ & $2 \times 10^{-6}$ \\
\hline \multirow[t]{3}{*}{ BMI $-715 \mathrm{~A}$} & 127 & $\mathrm{UO}_{2}$ & 42 & $\mathrm{Al}_{2} \mathrm{O}_{3}$ & None & CFP-S -7 & 100 & 11 & 0.0 & - & $3 \times 10^{-4}$ & $2 \times 10^{-4}$ \\
\hline & & & & & & & 100 & 479 & 1.5 & $4 \times 10^{-5}$ & $4 \times 10^{-5}$ & $2 \times 10^{-4}$ \\
\hline & & & & & & & 100 & 856 & 2.7 & $3 \times 10^{-5}$ & $3 \times 10^{-5}$ & $8 \times 10^{-5}$ \\
\hline \multirow[t]{5}{*}{$\mathrm{BMI}-? 15 \mathrm{~A}$} & 127 & $\mathrm{UO}_{2}$ & 42 & $\mathrm{Al}_{2} \mathrm{O}_{3}$ & None & CFP $-S-9$ & 815 & 18 & 0.1 & $4 \times 10^{-9}$ & $4 \times 10^{-9}$ & $4 \times 10^{-9}$ \\
\hline & & & & & & & 645 & 94 & 0.3 & $4 \times 10^{-9}$ & $4 \times 10^{-9}$ & $4 \times 10^{-9}$ \\
\hline & & & & & & & 470 & 170 & 0.5 & $3 \times 10^{-6}$ & $2 \times 10^{-6}$ & $1 \times 10^{-4}$ \\
\hline & & & & & & & 295 & 421 & 1.3 & $3 \times 10^{-5}$ & $1 \times 10^{-4}$ & $3 \times 10^{-4}$ \\
\hline & & & & & & & 815 & 597 & 1.9 & $4 \times 10^{-5}$ & $6 \times 10^{-5}$ & $3 \times 10^{-4}$ \\
\hline BMI $-715 \mathrm{~A}-\mathrm{HT}$ & 127 & $\mathrm{UO}_{2}$ & 42 & $\mathrm{Al}_{2} \mathrm{O}_{3}$ & None & CFP-S-11 & 100 & 8 & 0.0 & -. & -. & $1 \times 10^{-4}$ \\
\hline \multirow[t]{3}{*}{$\mathrm{BMI}-725 \mathrm{D}$} & 127 & $\mathrm{UO}_{2}$ & 56 & $\mathrm{Al}_{2} \mathrm{O}_{3}$ & Graphite & CFP $-S-6$ & 1070 & 43 & 0.2 & $8 \times 10^{-9}$ & $6 \times 10^{-9}$ & $5 \times 10^{-9}$ \\
\hline & & & & & & & $1070-440$ & 208 & 0.6 & $3 \times 10^{-6}$ & $2 \times 10^{-7}$ & $1 \times 10^{-6}$ \\
\hline & & & & & & & 750 & 1100 & 3.4 & $5 \times 10^{-7}$ & $1 \times 10^{-6}$ & $3 \times 10^{-6}$ \\
\hline \multirow[t]{3}{*}{ BMI $-736 \mathrm{~B}$} & 127 & $\mathrm{UO}_{2}$ & 16 & $\mathrm{Al}_{2} \mathrm{O}_{3}$ & Graphite & CFP-S -10 & 1050 & 42 & 0.2 & $3 \times 10^{-8}$ & $2 \times 10^{-8}$ & $6 \times 10^{-8}$ \\
\hline & & & & & & & 800 & 421 & 1.3 & $8 \times 10^{-6}$ & $2 \times 10^{-5}$ & $4 \times 10^{-4}$ \\
\hline & & & 27 & Lam PyC & & & 700 & 1871 & 5.8 & -- & $2 \times 10^{-4}$ & $9 \times 10^{-4}$ \\
\hline \multirow[t]{2}{*}{ BMI -845E } & 127 & $\mathrm{UO}_{2}$ & 60 & $\mathrm{BeO}$ & None & CFP $-S-3$ & 100 & 4 & 0.0 & $5 \times 10^{-5}$ & $2 \times 10^{-5}$ & $5 \times 10^{-6}$ \\
\hline & & & & & & & 100 & 758 & 2.4 & $1 \times 10^{-5}$ & $4 \times 10^{-5}$ & $2 \times 10^{-4}$ \\
\hline \multirow[t]{3}{*}{ BMI -918A } & 200 & $\mathrm{UC}_{2}$ & 55 & PyC & Graphite & CFP-S -2R & 1070 & 73 & 0.2 & $1 \times 10^{-8}$ & $2 \times 10^{-8}$ & $3 \times 10^{-8}$ \\
\hline & & & & & & & 1070 & 81 & 0.3 & $2 \times 10^{-4}$ & $1 \times 10^{-4}$ & $3 \times 10^{-3}$ \\
\hline & & & & & & & 1070 & 227 & 0.7 & $5 \times 10^{-3}$ & $5 \times 10^{-4}$ & $5 \times 10^{-3}$ \\
\hline \multirow[t]{3}{*}{ BMI -918A } & 200 & $\mathrm{UC}_{2}$ & 55 & PyC & None & CFP $-S-9$ & 815 & 18 & 0.1 & $3 \times 10^{-9}$ & $3 \times 10^{-9}$ & $3 \times 10^{-9}$ \\
\hline & & & & & & & 645 & 220 & 0.7 & $3 \times 10^{-6}$ & $2 \times 10^{-6}$ & $2 \times 10^{-5}$ \\
\hline & & & & & & & 815 & 597 & 1.9 & $5 \times 10^{-5}$ & $6 \times 10^{-5}$ & $3 \times 10^{-4}$ \\
\hline \multirow[t]{3}{*}{ BMI $-1010 \mathrm{~A}$} & 127 & $\mathrm{UO}_{2}$ & 66 & Pyc & Graphite & CFP-S - 8 & 1050 & $\begin{array}{r}9 \\
19\end{array}$ & 0.1 & $3 \times 10^{-8}$ & $4 \times 10^{-8}$ & $5 \times 10^{-8}$ \\
\hline & & & & & & & 1050 & 349 & 1.1 & $2 \times 10^{-5}$ & $1 \times 10^{-5}$ & $4 \times 10^{-5}$ \\
\hline & & & & & & & 850 & 1409 & 4.4 & $3 \times 10^{-5}$ & $5 \times 10^{-5}$ & $3 \times 10^{-4}$ \\
\hline
\end{tabular}


TABLE 2. (Contanued)

\begin{tabular}{|c|c|c|c|c|c|c|c|c|c|c|c|c|}
\hline \multirow[b]{3}{*}{ Lot } & \multicolumn{4}{|c|}{ Specimen Description } & \multirow[b]{3}{*}{ Matrix } & \multirow{3}{*}{$\begin{array}{c}\text { CFP } \\
\text { Irradiation } \\
\text { Capsule } \\
\end{array}$} & \multirow{3}{*}{$\begin{array}{c}\text { Nominal } \\
\text { Irradiation } \\
\text { Temperature, } \\
\text { C } \\
\end{array}$} & \multirow{3}{*}{$\begin{array}{l}\text { A ccumulated } \\
\text { Irradiation } \\
\text { Time, hr }\end{array}$} & \multirow{3}{*}{$\begin{array}{c}\text { Uranium } \\
\text { Bumup, } \\
\text { a/o }\end{array}$} & \multicolumn{3}{|c|}{$\mathrm{R} / \mathrm{B}(\mathrm{b})$} \\
\hline & \multicolumn{2}{|c|}{ Fuel } & \multicolumn{2}{|c|}{ Coating $(a)$} & & & & & & $\mathrm{Kr}^{85 \mathrm{~m}}, \mathrm{Kr}^{87}$ & & \\
\hline & Size, $\mu$ & Kind & Thickness, $\mu$ & Kind & & & & & & and $\mathrm{Kr} 88(\mathrm{c})$ & $\mathrm{Xe}^{135}$ & $\mathrm{Xe}^{133}$ \\
\hline HTM-1 & 200 & $\mathrm{UC}_{2}$ & 90 & Col-PyC & None & B9-7 & 820 & 1000 & 12.0 & $4 \times 10^{-5}$ & $6 \times 10^{-5}$ & $3 \times 10^{-4}$ \\
\hline $3 M-S P-2$ & 200 & $\mathrm{UC}_{2}$ & 90 & Lam-PyC & None & $\mathrm{Cl}-7$ & 820 & 500 & 15.0 & $3 \times 10^{-4}$ & $2 \times 10^{-4}$ & $5 \times 10^{-4}$ \\
\hline NCC-AD & 200 & $\mathrm{UC}_{2}$ & 90 & $\begin{array}{l}\text { Duplex- } \\
\text { PyC }\end{array}$ & None & $B 9-8$ & 820 & 480 & 14.7 & $9 \times 10^{-6}$ & $2 \times 10^{-5}$ & $7 \times 10^{-5}$ \\
\hline $3 M-101-U$ & 200 & $\mathrm{UC}_{2}$ & & None & None & C1-8 & 820 & 500 & 4.3 & $6 \times 10^{-3}$ & $8 \times 10^{-3}$ & $7 \times 10^{-2}$ \\
\hline
\end{tabular}

(a) Listed in order of preparation in the case of multsple coatings.

(b) Rate of release of isotope divided by rate of generation, values lusted are the release ratios at end of indicated time, except for the last four materials where values listed are average values over the indicated time period.

(c) Data are an average of the release fraction of the three krypton isotopes. 
The coated particles were irradiated in static capsules containing a helium atmosphere. Postirradiation studies included analyses of samples of gases released from the particles irradiated in static helium atmospheres, leaching of the uranium from irradiated specimens with nitric acid to determine the number of particles with failed coatings, heat treatment to determine fraction of gas retained in particles with failed coatings, and metallog raphic examination to study structural changes in the particles.

Sixty specimens comprising 12 types of coated particles have been irradiated at Battelle. All but a few of these specimens were removed from the capsules after irradiation and were examined. The results of postirradiation examinations of all specimens and in some instances the results of in-pile gas measurements are presented in Table 3.

The 60 specimens were irradiated at 100 to $1070 \mathrm{C}$ to burnups ranging up to 5.0 per cent of the uranium. The results of the postirradiation gas-release studies indicate, in general, that dense $\mathrm{Al}_{2} \mathrm{O}_{3}$ coatings experience nearly complete failure at $100 \mathrm{C}$ but perform much better at $1070 \mathrm{C}$. Coatings with a porous $\mathrm{Al}_{2} \mathrm{O}_{3}$ layer between two dense $\mathrm{Al}_{2} \mathrm{O}_{3}$ layers perform better at $100 \mathrm{C}$ than fully dense $\mathrm{Al}_{2} \mathrm{O}_{3}$ coatings, but their performance does not improve at the elevated temperature. Studies indicate that there is not a significant improvement in gas-retention ability of particles dispersed in a graphite matrix. The results of analyses of acid solutions used to leach the specimens indicate in a number of cases a greater degree of coating failure than was indicated by the postirradiation gas-release studies. An investigation into the source of the lack of agreement between these two techniques has not yet resolved this discrepancy.

The results of postirradiation examinations of gas release from pyrolytic-carboncoated particles are less consistent than data from examinations of alumina-coated particles. However, in general, the data indicate that pyrolytic-carbon coatings fail more severely than $\mathrm{Al}_{2} \mathrm{O}_{3}$ coatings at 100 to $1070 \mathrm{C}$.

The investigations of coated particles conducted at Oak Ridge have been concerned with pyrolytic-carbon-coated $\mathrm{UC}_{2}$ particles. The thickness of the coatings on the particles studied have been as large as $161 \mu$. Coated particles have been irradiated in both the unsupported condition and supported in a graphite matrix. Coated-particle specimens have been irradiated at temperatures ranging from 475 to $1425 \mathrm{C}$ and to burnups as high as $7.2 \times 1020$ fissions per $\mathrm{cm}^{3}$. After irradiation, gas release from the particles was measured at room temperature and at elevated temperatures as high as $2050 \mathrm{C}$.

The results of these studies indicate that gas release is independent of the irradiation exposure within the range investigated. However, the gas release is temperature dependent, gas release increasing with irradiation temperature. It was concluded that the fission-gas release from the pyrolytic-carbon-coated particles occurs by diffusion through the coatings. A diffusion coefficient of $1.41 \times 10^{-10} \mathrm{~cm}^{2}$ per sec was determined for the release of Xel33 through the coatings of Type HTM-1 particles. It was also observed that the crushing strength of these particles was increased during irradiation.

The studies being conducted by General Atomic have dealt primarily with pyrolytic-carbon-coated $\mathrm{UC}_{2}$ particles irradiated in graphite matrices. Particles with coatings ranging in thickness from 10 to $60 \mu$ have been irradiated in six capsules to 
TABLE 3. SUMMARY OF RESULTS OF POSTIRRA DIA TION EXAMINA TION OF COA TED-PARTICLE SPECIMENS

\begin{tabular}{|c|c|c|c|c|c|c|c|c|c|c|}
\hline \multirow[b]{2}{*}{$\begin{array}{l}\text { Coated } \\
\text { Fuel Lot }\end{array}$} & \multicolumn{2}{|c|}{ Fuel } & \multicolumn{2}{|c|}{ Coating(a) } & \multirow[b]{2}{*}{$\begin{array}{c}\text { Irradiation } \\
\text { Capsule }\end{array}$} & \multirow[b]{2}{*}{$\begin{array}{c}\text { Matrix } \\
\text { Support }(b)\end{array}$} & \multirow{2}{*}{$\begin{array}{c}\text { Irradiation } \\
\text { Temperature, } \\
\text { C }\end{array}$} & \multirow{2}{*}{$\begin{array}{c}\mathrm{U}^{235} \\
\text { Fission Burnup, } \\
\text { per cent }\end{array}$} & \multirow{2}{*}{$\begin{array}{c}\text { Fractional(c) } \\
\text { Xe } \\
\text { Release, } \\
\text { ppm }\end{array}$} & \multirow{2}{*}{$\begin{array}{c}\text { Uranium } \\
\text { Removed } \\
\text { in Leach, } \\
\text { per cent }\end{array}$} \\
\hline & Material & $\begin{array}{c}\text { Diameter, } \\
\mu\end{array}$ & Material & $\begin{array}{c}\text { Thickness, } \\
\mu\end{array}$ & & & & & & \\
\hline \multicolumn{11}{|c|}{ Specimens With A lumina Coatings } \\
\hline \multirow[t]{5}{*}{ BMI-4E } & $\mathrm{UO}_{2}$ & 127 & $\mathrm{~d}-\mathrm{Al}_{2} \mathrm{O}_{3}$ & 8 & & & & & & \\
\hline & & & $\mathrm{p}-\mathrm{Al}_{2} \mathrm{O}_{3}$ & 6 & & & & & & \\
\hline & & & $\mathrm{d}-\mathrm{Al}_{2} \mathrm{O}_{3}$ & 28 & CFP -4 & None & 100 & 2.9 & 8.1 & 28 \\
\hline & & & & & CFP-S -5 & Graphite & 1070 & 3.9 & 0.29 & 0.65 \\
\hline & & & & & CFP $-S-5$ & Graphite & 1070 & 3.8 & -- & -- \\
\hline \multirow[t]{12}{*}{ BMI-715A } & $\mathrm{UO}_{2}$ & 127 & $\mathrm{~d}-\mathrm{Al}_{2} \mathrm{O}_{3}$ & 42 & CFP-1D & None & 100 & 3.3 & 100 & 54 \\
\hline & & & & & CFP-1B & None & 100 & 4.7 & 120 & 39 \\
\hline & & & & & CFP -4 & None & 100 & 3.0 & 100 & $>7$ \\
\hline & & & & & CFP-S -7 & None & 100 & 3.9 & 50 & 5 \\
\hline & & & & & CFP $-S-7$ & None & 100 & 4.0 & -- & $>82$ \\
\hline & & & & & CFP-S - 9 & None & $815-295^{(d)}$ & -- & -. & 68 \\
\hline & & & & & CFP-1C & None & 1070 & 1.7 & 0.09 & 0.9 \\
\hline & & & & & CFP-1A & None & 1070 & 3.2 & 0.02 & 0.2 \\
\hline & & & & & CFP-1D & Graphite & 100 & 3.5 & 1.9 & 33 \\
\hline & & & & & CFP-1B & Graphite & 100 & 5.0 & 0.7 & $43 ; 38^{(e)}$ \\
\hline & & & & & CFP-1C & Graphite & 1070 & 1.7 & - & 0.007 \\
\hline & & & & & CFP-1A & Graphite & 1070 & 3.3 & -- & -- \\
\hline \multirow[t]{4}{*}{ BMI -7I5A - HT } & $\mathrm{UO}_{2}$ & 127 & $\mathrm{~d}-\mathrm{A}_{2} \mathrm{O}_{3}$ & 42 & $\mathrm{CFP}-\mathrm{S}-7$ & None & 100 & 3.9 & 0.01 & 95 \\
\hline & & & & & CFP-S-8 & None & 1070 & 4 (est.) & 87 & -- \\
\hline & & & & & CFP $-S-7$ & Graphite & 100 & 3.6 & 0.39 & 93 \\
\hline & & & & & CFP-S -8 & Graphite & 1070 & 4 (est.) & 18,000 & -- \\
\hline \multirow[t]{2}{*}{ BMI - 717B } & $\mathrm{UO}_{2}$ & 127 & $\mathrm{~d}-\mathrm{Al}_{2} \mathrm{O}_{3}$ & 43 & CFP $-5-7$ & None & 100 & 3.9 & -. & 1.5 \\
\hline & & & & & CFP -S-8 & None & 1070 & 4 (est.) & 190 & -- \\
\hline \multirow[t]{6}{*}{ BMI-721C } & $\mathrm{UO}_{2}$ & 127 & $\mathrm{~d}-\mathrm{Al}_{2} \mathrm{O}_{3}$ & 8 & & & & & & \\
\hline & & & $\mathrm{p}-\mathrm{Al}_{2} \mathrm{O}_{3}$ & 18 & & & & & & \\
\hline & & & $\mathrm{d}-\mathrm{Al}_{2} \mathrm{O}_{3}$ & 28 & CFP-1D & None & 100 & 3.4 & 1.8 & 88 \\
\hline & & & & & CFP-1B & None & 100 & 4.6 & 15 & 5 \\
\hline & & & & & CFP -4 & None & 100 & 3.1 & 26 & 95 \\
\hline & & & & & CFP - $1 \mathrm{C}$ & None & 1070 & 1.7 & 4.0 & 3 \\
\hline
\end{tabular}


TABLE 3. (Continued)

\begin{tabular}{|c|c|c|c|c|c|c|c|c|c|c|}
\hline \multirow[b]{2}{*}{$\begin{array}{l}\text { Coated } \\
\text { Fuel Lot }\end{array}$} & \multicolumn{2}{|c|}{ Fuel } & \multicolumn{2}{|c|}{ Coating $(a)$} & \multirow[b]{2}{*}{$\begin{array}{l}\text { Irradiation } \\
\text { Capsule }\end{array}$} & \multirow[b]{2}{*}{$\begin{array}{l}\text { Matrix } \\
\text { Support }(b)\end{array}$} & \multirow{2}{*}{$\begin{array}{c}\text { Irradiation } \\
\text { Temperature, } \\
\text { C }\end{array}$} & \multirow{2}{*}{$\begin{array}{c}\mathrm{U}^{235} \\
\text { Fission Burnup, } \\
\text { per cent }\end{array}$} & \multirow{2}{*}{$\begin{array}{c}\text { Fractional(c) } \\
\text { Xe }^{133} \\
\text { Release, } \\
\text { ppm }\end{array}$} & \multirow{2}{*}{$\begin{array}{l}\text { Uranium } \\
\text { Removed } \\
\text { in Leach, } \\
\text { per cent }\end{array}$} \\
\hline & Material & $\begin{array}{c}\text { Diameter, } \\
\mu\end{array}$ & Material & $\begin{array}{c}\text { Thickness, } \\
\mu\end{array}$ & & & & & & \\
\hline \multicolumn{11}{|c|}{$\frac{\text { Specimens With Alumina Coatings }}{\text { (Continued) }}$} \\
\hline & & & & & CFP-1A & None & 1070 & 3.2 & 44 & 0.5 \\
\hline & & & & & CFP-1D & Graphite & 100 & 3.4 & -- & 44 \\
\hline & & & & & CFP - $1 \mathrm{~B}$ & Graphite & 100 & 4.8 & 1.8 & 30 \\
\hline & & & & & CFP-1C & Graphite & 1070 & 1.7 & -- & 0.004 \\
\hline & & & & & CFP-1A & Graphite & 1070 & 3.4 & 130 & - \\
\hline & & & & & CFP-1D & Carbon & 100 & 3.0 & -- & 33 \\
\hline & & & & & CFP - $1 B$ & Carbon & 100 & 4.9 & 32 & 43 \\
\hline & & & & & $\mathrm{CFP}-1 \mathrm{C}$ & Carbon & 1070 & 1.6 & -- & 0.5 \\
\hline & & & & $=$ & CFP-1A & Carbon & 1070 & 3.3 & - & 0.09 \\
\hline \multirow[t]{4}{*}{ BMI-725D } & $\mathrm{UO}_{2}$ & 127 & $\mathrm{~d}-\mathrm{A}_{2} \mathrm{O}_{3}$ & 56 & CFP $-S-7$ & None & 100 & 3.9 & 17 & 0.3 \\
\hline & & & & & CFP -S - 6 & None & 1070 & 3 (est.) & 760 & -- \\
\hline & & & & & CFP $-S-6$ & Graphite & 1070 & 3 (est.) & $34^{(f)}$ & 2.4 \\
\hline & & & & & CFP-S -6 & Graphite & 1070 & 3 (est.) & -- & 1.8 \\
\hline \multirow[t]{2}{*}{ BMI - 733B } & $\mathrm{UO}_{2}$ & 127 & $\mathrm{~d}-\mathrm{A}_{1} \mathrm{O}_{3}$ & 47 & CFP $-S-7$ & None & 100 & 3.9 & -- & 3 \\
\hline & & & & & CFP -S - 8 & None & 1070 & 4 (est.) & 28 & -- \\
\hline \multicolumn{11}{|c|}{ Specimens With Pyrolytic-Carbon Coatings } \\
\hline \multirow[t]{6}{*}{ BMI-918A } & $\mathrm{UC}_{2}$ & 200 & Col PyC & 55 & CFP -4 & None & 100 & 3.1 & 190 & 93 \\
\hline & & & & & CFP $-S-9$ & None & $815-470(g)$ & - & -- & -. \\
\hline & & & & & CFP $-S-2$ & None & 1070 & Nil &.- & -- \\
\hline & & & & & CFP $-S-5$ & None & 1070 & 3.8 & 5,200 & 21 \\
\hline & & & & & CFP -S - 2 & Graphite & 1070 & Nil & - & -. \\
\hline & & & & & CFP-S -2R & Graphite & 1070 & 1.8 & -- & -- \\
\hline \multirow[t]{3}{*}{ BMI $-919 A$} & $\mathrm{UC}_{2}$ & 200 & Lam PyC & 70 & CFP -4 & None & 100 & 3.2 & 14 & -- \\
\hline & & & & & CFP $-S-5$ & None & 1070 & 3.7 & 7,500 & 55 \\
\hline & & & & & CFP $-S-6$ & Graphite & 1070 & 3 (est.) & $35^{(h)}$ & 5.7 \\
\hline
\end{tabular}


TABLE 3. (Continued)

\begin{tabular}{|c|c|c|c|c|c|c|c|c|c|c|}
\hline \multirow[b]{2}{*}{$\begin{array}{l}\text { Coated } \\
\text { Fuel Lot }\end{array}$} & \multicolumn{2}{|c|}{ Fuel } & \multicolumn{2}{|c|}{ Coating $(a)$} & \multirow[b]{2}{*}{$\begin{array}{l}\text { Irradiation } \\
\text { Capsule }\end{array}$} & \multirow[b]{2}{*}{$\begin{array}{l}\text { Matrix } \\
\text { Support }\end{array}$} & \multirow{2}{*}{$\begin{array}{c}\text { Irradiation } \\
\text { Temperature, } \\
\text { C }\end{array}$} & \multirow{2}{*}{$\begin{array}{c}U^{235} \\
\text { Fission Burnup, } \\
\text { per cent }\end{array}$} & \multirow{2}{*}{$\begin{array}{c}\text { Fractional(c) } \\
X \mathrm{e}^{133} \\
\text { Release, } \\
\text { ppm }\end{array}$} & \multirow{2}{*}{$\begin{array}{l}\text { Uranium } \\
\text { Removed } \\
\text { in Leach, } \\
\text { per cent }\end{array}$} \\
\hline & Material & $\begin{array}{c}\text { Diameter, } \\
\mu \\
\end{array}$ & Material & $\begin{array}{c}\text { Thickness, } \\
\mu\end{array}$ & & & & & & \\
\hline \multicolumn{11}{|c|}{$\frac{\text { Specimens With Pyrolytic-Carbon Coatings }}{\text { (Continued) }}$} \\
\hline \multirow[t]{4}{*}{ BMI $-920 \mathrm{~A}$} & $\mathrm{UO}_{2}$ & 127 & Lam PyC & 45 & CFP -4 & None & 100 & 3.4 & 220 & 30 \\
\hline & & & & & CFP $-S-7$ & None & 100 & 3.7 & 70 & 3 \\
\hline & & & & & CFP $-S-5$ & None & 1070 & 3.8 & 19,000 & 66 \\
\hline & & & & & CFP-S-6 & Graphite & 1070 & 3 (est.) & 470 & 90 \\
\hline \multirow[t]{5}{*}{$\mathrm{BMI}-921$} & $\mathrm{UO}_{2}$ & 127 & $\mathrm{~d}-\mathrm{Al}_{2} \mathrm{O}_{3}{ }^{(\mathrm{i})}$ & 48 & & & & & & \\
\hline & & & Mix PyC & 32 & CFP-1D & None & 100 & 3.1 & 48 & 46 \\
\hline & & & & & CFP - IB & None & 100 & 4.9 & 16 & 2.2 \\
\hline & & & & & CFP-IC & None & 1070 & 1.6 & 0.13 & 7.2 \\
\hline & & & & & CFP-1A & None & 1070 & 3.3 & 0.04 & 3.0 \\
\hline \multirow[t]{3}{*}{ BMI-1010A } & $\mathrm{UO}_{2}$ & 127 & Lam PyC & 66 & CFP $-S-7$ & None & 100 & 3.6 & - & 0.1 \\
\hline & & & & & CFP-S-8 & None & 1070 & 4 (est.) & 15,000 & -- \\
\hline & & & & & CFP-S -8 & Graphite & 1070 & 4 (est.) & - & -- \\
\hline $3 M-10695-47$ & $\mathrm{UC}_{2}$ & -- & PyC & $48-161$ & -- & None & - & - & $\begin{array}{l}1825 \mathrm{C}: .003 \%{ }^{(\mathrm{j})} \\
2050 \mathrm{C}: 29 \% \mathrm{~d}^{\mathrm{k})} \\
1960: \mathrm{nil}(\mathrm{l})\end{array}$ & \\
\hline \multirow[t]{3}{*}{$3 M-S P-2$} & $\mathrm{UC}_{2}$ & 250 & PyC & 82 & -- & None & $475-980$ & $7.2 \times 10^{20}$ f per $\mathrm{cm}^{3}$ & -- & $\begin{array}{l}5 \% \text { failed by } \\
\text { visual exam }\end{array}$ \\
\hline & & & & & LCP -2 & None & $1260-1315$ & $3.8 \times 10^{20} \mathrm{f}$ per $\mathrm{cm}^{3}$ & $2000 \mathrm{Kr}-85$ & \\
\hline & & & & & & & & & $500-900 \mathrm{Xe}-133$ & 0.6 to 10 \\
\hline \multicolumn{11}{|l|}{ 3M (Pellet } \\
\hline 1080) & $\mathrm{UC}_{2}$ & -- & PyC & -- & MTR-48-5 & Graphite & $840-1425$ & 17 & - & -- \\
\hline HTM-1 & $\mathrm{UC}_{2}$ & - & PyC & 109 & B $9-7$ & None & $815-900$ & $1.56 \times 10^{20} \mathrm{f}_{\text {per }} \mathrm{cm}^{3}$ & - & $\cdots$ \\
\hline & & & & & LCP-1 & None & $1065-1150$ & $3.8 \times 10^{20} \mathrm{f}$ per $\mathrm{cm}^{3}$ & 100 to $1000 \mathrm{Kr}$ & 2 to 22 \\
\hline NCC-AD & $\mathrm{UC}_{2}$ & $-\cdot$ & PyC & $100-103$ & $\cdots$ & None & 815 & - & - & -- \\
\hline GA & $\mathrm{UC}_{2}$ & -- & PyC & $10-15$ & $G A-309-7$ & Graphite & $1000-1700$ & $0.82 \times 10^{20} \mathrm{f}$ per $\mathrm{cm}^{3}$ & -- & $\cdots$ \\
\hline
\end{tabular}




\begin{tabular}{|c|c|c|c|c|c|c|c|c|c|c|}
\hline \multirow[b]{2}{*}{$\begin{array}{c}\text { Coated } \\
\text { Fuel Lot } \\
\end{array}$} & \multicolumn{2}{|c|}{ Fuel } & \multicolumn{2}{|c|}{ Coating(a) } & \multirow[b]{2}{*}{$\begin{array}{c}\text { Irradiation } \\
\text { Capsule }\end{array}$} & \multirow[b]{2}{*}{$\begin{array}{c}\text { Matrix } \\
\text { Support(b) }\end{array}$} & \multirow{2}{*}{$\begin{array}{c}\text { Irradiation } \\
\text { Temperature, } \\
\text { C }\end{array}$} & \multirow{2}{*}{$\begin{array}{c}U^{235} \\
\text { Fission Burnup, } \\
\text { per cent }\end{array}$} & \multirow{2}{*}{$\begin{array}{c}\text { Fractional(c) } \\
\mathrm{Xe}^{133} \\
\text { Release, } \\
\text { ppm }\end{array}$} & \multirow{2}{*}{$\begin{array}{l}\text { Uranium } \\
\text { Removed } \\
\text { in Leach, } \\
\text { per cent }\end{array}$} \\
\hline & Material & $\begin{array}{c}\text { Diameter, } \\
\mu\end{array}$ & Material & $\begin{array}{c}\text { Thickness, } \\
\mu\end{array}$ & & & & & & \\
\hline \multicolumn{11}{|c|}{ Specimens With Pyrolytic-Carbon Coatings } \\
\hline & & & & & (Cont & nued) & & & & \\
\hline GA & $\mathrm{UC}_{2}$ & - & PyC & 25 & $\begin{array}{c}G A-309-4 \\
-5,-6\end{array}$ & Graphite & $850-1950$ & $1.2 \times 10^{20}{\mathrm{f} \mathrm{per} \mathrm{cm}^{3}}^{3}$ & - & -- \\
\hline \multirow[t]{2}{*}{ GA } & $\mathrm{UC}_{2}$ & -- & PyC & $50-60$ & $G A-309-8$ & Graphite & $1200-2050$ & $0.82 \times 10^{20}$ f per $\mathrm{cm}^{3}$ & - & -- \\
\hline & & & & & GA $-309-9$ & Graphite & $1250-1600$ & $0.82 \times 10^{20} \mathrm{f}_{\text {per }} \mathrm{cm}^{3}$ & - & -- \\
\hline
\end{tabular}

(a) In order of deposition. Code used is as follows:

d- $\mathrm{Al}_{2} \mathrm{O}_{3}$ : Essentially fully dense $\mathrm{Al}_{2} \mathrm{O}_{3}$ layer.

$\mathrm{P}-\mathrm{Al}_{2} \mathrm{O}_{3}$ : Relatively porous $\mathrm{Al}_{2} \mathrm{O}_{3}$ layer.

Col PyC: Pyrolytic carbon with a columnar or radially oriented structure.

Lam PyC: Pyrolytic carbon with a laminar or circumferentially oriented structure.

Mix PyC: Pyrolytic carbon with a mixed columnar and laminar structure.

(b) Three conditions of matrix support existed:

1. None: no support from a matrix.

2. Graphite: support afforded by a relatively graphitized matrix.

3. Carbon: support afforded by a relatively ungraphitized matrix.

(c) Ratio of fission product detected to total amount present at time of sampling.

(d) Step-temperature capsule. Initial irradiation temperature was $815 \mathrm{C}$. This was lowered successively at about 2-day intervals to 645 , 470 , and $295 \mathrm{C}$.

(e) This specimen consisted of two fueled-graphite pellets. Leach of one pellet as recovered from the capsules yielded 43 per cent uranium recovery. Second pellet was heated to $815 \mathrm{C}$ at which temperature $270 \mathrm{ppm}$ of $\mathrm{Kr}^{85}$ was driven off. Subsequent leach of second pellet yielded 38 per cent of uranium recovery.

(f) This specimen consisted of two fueled-graphite pellets. Analysis of gases sampled from within the specimen can after irradiation indicated 30 ppm of $\mathrm{Xe}$ (33 was released by both pellets. Subsequent heating of one pellet to $540 \mathrm{C}$ drove off an additional $1.4 \mathrm{ppm}$ of $\mathrm{Xe}^{133}$.

(g) Step-temperature capsule. Initial irradiation temperature was $815 \mathrm{C}$. This was lowered successively at approximately 2 -day intervals to 645 and $470 \mathrm{C}$.

(h) This specimen consisted of two fueled-graphite pellets. A nalysis of gases sampled from within the specimen can after irradiation indicated 30 ppm of Xe 133 was released by both pellets. Subsequent heating of one pellet to $540 \mathrm{C}$ drove off an additional $33 \mathrm{ppm}$ of Xe $\mathrm{e}^{133}$.

(i) Alumina coating was cracked prior to irradiation as a result of overcoating with pyrolytic carbon.

(j) Heat treated at $1825 \mathrm{C}$ for $90 \mathrm{hr}$. When the temperature was increased to $2290 \mathrm{C}$, the gas release increased.

(k) Heat treated at $2050 \mathrm{C}$ for $103 \mathrm{hr}$; gas release detected after $37 \mathrm{hr}$ of heating.

(1) Heat treated at $1960 \mathrm{C}$ for $140 \mathrm{hr}$. 
PART.

burnups of $0.82 \times 10^{20}$ to $1.2 \times 10^{20}$ fissions per $\mathrm{cm}^{3}$. Irradiation temperatures ranged between 850 and $2000 \mathrm{C}$. Only in-pile gas-release data have been reported. Within the limits tested, gas release varied from about 1 per cent at the beginning of irradiation to near 100 per cent at the end of irradiation. The gas release appeared to be temperature independent but there may be a delayed temperature effect. Activation energies for fission-gas release were calculated. They ranged from 24.1 to 29.1 kcal per mole for four krypton isotopes and from 33.4 to $45.8 \mathrm{kcal}$ per mole for two xenon isotopes.

\section{References}

(1) "40MW(E) Prototype High-Temperature Gas-Cooled Reactor Research and Development Progress", GA-1982 (July 1961), p 7.

(2) Parker, W. E. , "Development of Graphite Matrix Fuel Elements", Trans. Am. Nuclear Soc., $\underline{4}$ (2), 343 (November, 1961).

(3) "Interum Status Report Phase III Graphite-Matrix Nuclear Fuel Elements", National Carbon Company, ORO-481 (June 30, 1961), p 17.

(4) Goeddel, W. V., "The Development and Evaluation of Graphite-Matrix Fuel Compacts for the HTGR", GA-2289 (August 8, 1961).

(5) Dayton, R. W., and Dickerson, R. F., "Progress Relating to Civilian Applications During February, 1962", BMI-1569 (Del) 11 (March 1, 1962), p L-10.

(6) Dayton, R. W. , and Dickerson, R. F., "Progress Relating to Civilian Applications During September, 1962", BMI-1593 (Del.) (September 1962).

(7) Harms, W. O., "Coated Particle Fuel Element Development Activity Letter for the Period March 15 to May 15, 1962", CF-62-6-75 (June 29, 1962). 


\section{CONVERSION EQUIVALENTS}




\section{CONVERSION EQUIVALENTS}

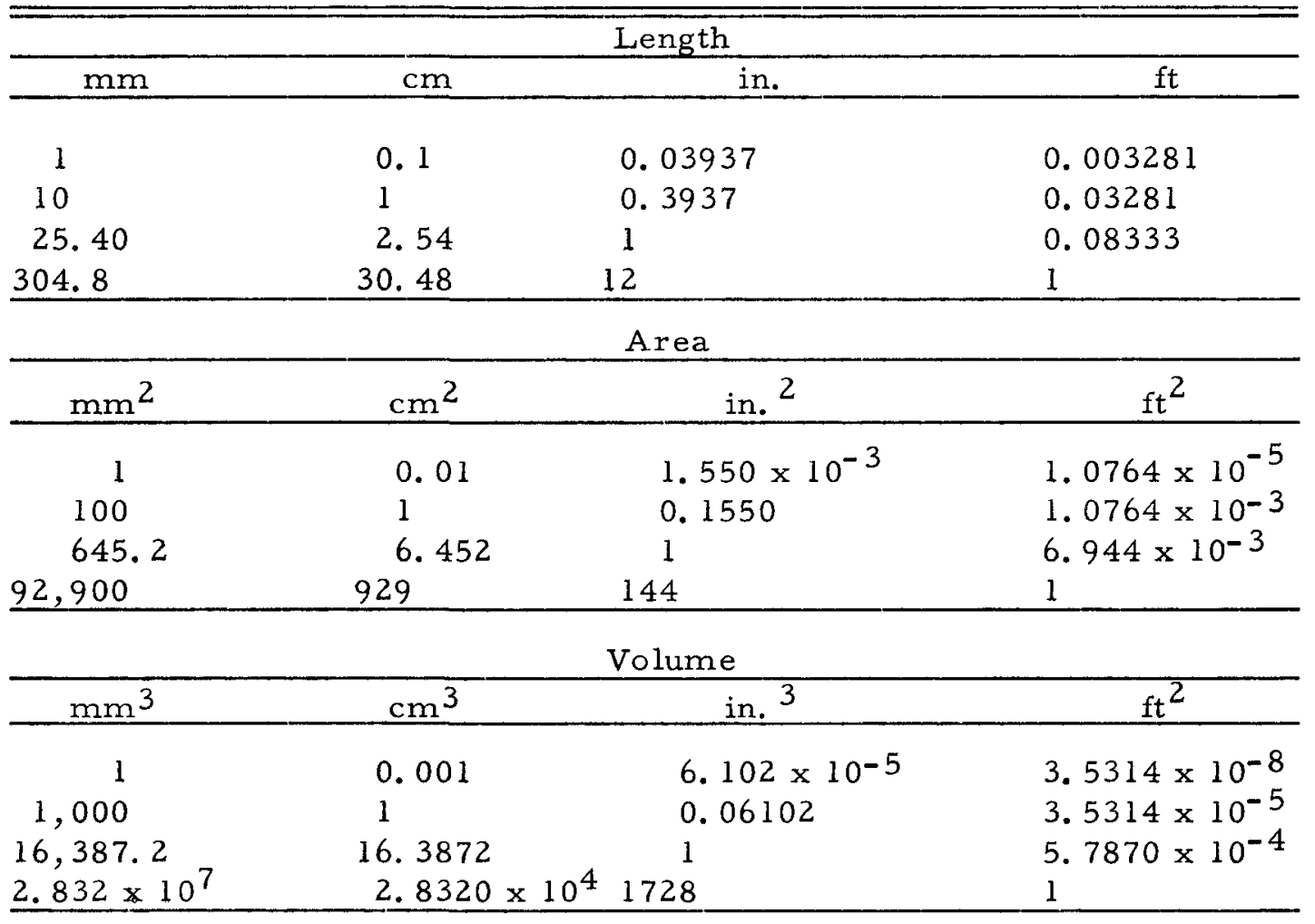

Note: 1 British dry butt $=0.5781$ cubic meter.

Mass

$\begin{array}{ll}1 \mathrm{~g} & =0.002205 \mathrm{lb} \text { (avoir) } \\ 1 \mathrm{lb} & =453.59 \mathrm{~g}\end{array}$

1 ton, US (short) $=2000 \mathrm{lb}$ (avoir) $=0.8929$ ton long $=$

0.9072 metric ton or tonne

Density

\begin{tabular}{|c|c|c|c|}
\hline $\mathrm{g} / \mathrm{cm}^{3}$ & $1 \mathrm{~b} /$ in. $^{3}$ & $\mathrm{lb} / \mathrm{ft}^{3}$ & \\
\hline 1 & 0.03613 & 62.43 & \\
\hline 27.68 & 1 &, 728 & \\
\hline 0.01602 & 0.0005787 & 1 & \\
\hline \multicolumn{4}{|c|}{ Pressure } \\
\hline $\mathrm{atm}$ & $\mathrm{mm} \mathrm{Hg}$ & lb/in. 2 & \\
\hline 1 & 760 & 4.70 & \\
\hline 1.316 & 1000 & 9.34 & \\
\hline 0.06804 & 51.710 & 1 & \\
\hline \multicolumn{4}{|c|}{ Energy } \\
\hline Joules & $\mathrm{w}-\mathrm{hr}$ & Btu & g-cal \\
\hline 1 & $2.7778 \times 10^{-4}$ & $9.486 \times 10^{-4}$ & 0.239 \\
\hline $3.6 \times 10^{3}$ & 1 & .3 .415 & 860.445 \\
\hline 1054 & 0.2928 & 1 & 252 \\
\hline
\end{tabular}


(Continued)

\section{Thermal Conductivity}

\begin{tabular}{|c|c|c|c|c|}
\hline $\begin{array}{c}\mathrm{g}-\mathrm{cal} /(\mathrm{sec})\left(\mathrm{cm}^{2}\right) \\
(\mathrm{C} \text { per } \mathrm{cm}) \\
\end{array}$ & $\begin{array}{c}w /\left(\mathrm{cm}^{2}\right) \\
(C \operatorname{per} \mathrm{cm})\end{array}$ & $\begin{array}{c}\mathrm{g}-\mathrm{cal} /(\mathrm{hr})\left(\mathrm{cm}^{2}\right) \\
(\mathrm{C} \text { per } \mathrm{cm}) \\
\end{array}$ & $\begin{array}{c}\mathrm{Btu} /(\mathrm{hr})\left(\mathrm{ft}^{2}\right) \\
(\mathrm{F} \text { per in. }) \\
\end{array}$ & $\begin{array}{c}\mathrm{Btu} /(\mathrm{hr})\left(\mathrm{ft}^{2}\right) \\
(\mathrm{F} \text { per } \mathrm{ft}) \\
\end{array}$ \\
\hline 1 & 4.183 & 3600 & 2903.0 & 241.917 \\
\hline 0.2391 & 1 & 860.6 & 694.0 & 57.833 \\
\hline 2. $78 \times 10^{-4}$ & $1.162 \times 10^{-3}$ & 1 & 0.8064 & 0.0672 \\
\hline 3. $445 \times 10^{-4}$ & $1.440 \times 10^{-3}$ & 1.240 & 1 & 0.08333 \\
\hline $4.13 \times 10^{-3}$ & 0.0173 & 14.880 & 12 & 1 \\
\hline
\end{tabular}

1 microhm-in. $=2.5400 \mathrm{microhm}-\mathrm{cm}$

$1 \mathrm{microhm}-\mathrm{cm}=0.3937 \mathrm{microhm}-\mathrm{in}$.

\section{Fission Units}

$1 \mathrm{~g}$ of uranium fissioned

1 a/o uranium burnup

1 a/o uranium burnup

$0.109 \mathrm{a} / \mathrm{o}$ uranium burnup
$0.120 \mathrm{a} / \mathrm{o}$ uranium burnup
$=0.919$ megawatt-day (MWD)

$=9190 \mathrm{MWD} /$ metric ton (tonne) of uranium

$=8360 \mathrm{MWD} / \mathrm{U}$. S. ton of uranium

$=1000 \mathrm{MWD} /$ metric ton of uranium

$=1000 \mathrm{MWD} / \mathrm{U}$. S. ton of uranium

Cross Section

1 barn $=10^{-24} \mathrm{~cm}^{2}$

$\frac{\mathrm{cm}^{2}}{\mathrm{~g}}=\left(\frac{\text { barns }}{\text { atom }}\right)\left(\frac{0.602}{\mathrm{~mol} . \mathrm{wt} .}\right)$ 